\title{
BERGEN'S ELEMENTS OF BOTANY
}

\section{QK 47 \\ .B494 \\ Copy 1}

$$
\text { BOSTON, U.S.A. }
$$

GINN \& COMPANY, PUBLISHERS

(Tbe Qtbenxum press 


$$
\text { ชै }
$$






\section{BERGEN'S ELEMENTS OF BOTANY}

\section{KEY AND FLORA}

SOUTHERN UNITED STATES EDITION

BY

S. M. TRACY, M.S.

FORMERLY PROFESSOR OF BOTANY IN THE

STATE UNIVERSITY OF MISSOURI

BOSTON, U.S.A.

GINN \& COMPANY, PUBLISHERS

The Atbenaum press

1899 


\section{nov 211899}

46745
CopYriaht, 1899, ву

S. M. TRACY

ALL RIGHTS RESERVED

TWO COPIES RECEIVED.

SECOND COPY,

Nur 4- 1889

of Copyris

72490

400.6.99, 


\title{
PART II.
}

\section{FLORA 0F THE SOUTHERN UNITED STATES.}

BY

\author{
S. M. TRACY, M.S.,
}

Late Director and Botanist of the Mississippi Agricultural Experiment Station, formerly Professor of Botany, Missouri State University. 



\section{PR E F AC E.}

This manual is designed for the use of secondary schools in the southeastern part of the United States, from North Carolina southward to Florida and westward to Texas. It does not purport to give all the known flowering plants of that region, but gives the more common species blooming in the early summer before the close of the school year, together with a few of those which are prominent later in the season. In the selection of the species given, only such as may be identified with clearness and certainty have been included; while some, although very common, which are separated from others only by minute and technical differences, have been omitted. The object of the work is not so much to enable the student to name the family, genus, and species of every plant he may find, as to enable him to learn how plants are classified, something of the relations and differences of the more important groups, and the process by which an unknown plant may be identified. The ability to identify and name plants is not the object of botanical study, but it is a great assistance in attaining the knowledge which the true student of botany is seeking - an understanding of the laws of life in the vegetahle kingdom. 
It is suggested to teachers using this book that they should take pains to secure for class-room study only such plants as are described in the manual, that time may not be wasted and pupils discouraged by efforts to identify species which are too difficult for elementary work. The illustrations are from Bergen's text-book, and are used with the original numbers. In preparing the descriptions living plants have been examined whenever possible, while free use has been made of Chapman's Flora of the Southern States, Gray's Synoptical Flora, Britton and Brown's Illustrated Flora, and other botanical works.

Biloxi, Miss., March 15, 1899. 


\section{KEY TO THE FAMILIES OF PHANEROGAMS DESCRIBED IN THIS MANUAL.}

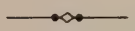

\section{CLASS I.}

GYMNOSPERMS. Ovules not enclosed in an ovary.

Trees or shrubs; leaves usually evergreen and needle-shaped or scale-like; flowers monœcious or diœcious ; fruit a dry or fleshy cone.

1. Pinaceæ.

\section{CLASS II.}

\section{ANGIOSPERMS. Ovules enclosed in an ovary.}

Subclass 1. - Monocotyledons. Flowers usually on the plan of 3, never of 5 ; leaves usually parallel-veined; cotyledon single.

Flowers glumaceous.

Flowers 2-bracted ; leaves 2-ranked; stem cylindrical . . . . . . 4. Gramineæ.

Flowers 1-bracted; leaves 3-ranked; stem triangular . . . . . . 5. Суреraceæ.

Flowers on a spadix.

Spadix spike-like; perianth of bristles . 2. Typhaceæ.

Spadix simple, fleshy . . . . . 7. Araceæ.

Spadix branched . . . . . 6. Sabalaceæ.

Flowers not on a spadix."

Carpels several, distinct . . . . . 3: Alismaceæ.

Carpels united.

Perianth free, or united only to the base of the ovary.

Perianth regulạr, segments chaffi . . . 11. Juncaceæ. 
Perianth regular; in 2 series, the outer sepal-

like.

Epiphytes or parasites .

8. Bromeliaceæ.

Terrestrial, petals deliquescent . . . 9. Commelinaceæ.

Terrestrial, petals withering-persistent .

Perianth regular, segments nearly alike, petaloid.

Fruit capsular.

Styles distinet or partly united . . 12. Melanthaceæ.

Styles wholly united . . . . . 13. Liliaceæ.

Fruit berry-like.

Stems climbing by tendrils . . . 15. Smilaceæ.

Stems not climbing . . . . . 14. Convallariaceæ.

Perianth irregular.

Perianth in 2 series, the outer sepal-like .

Perianth in a single series, the segments united

9. Commelinaceæ.

10. Pontederiaceæ.

Perianth adnate to the ovary.

Stamens with anthers, 1 or 2 . . . .

Stamens 3, opposite the inner perianth segments.

19. Orchidaceæ.

Stamens 3, opposite the outer perianth segments .

16. Hæmodoraceæ.

Stamens 6

18. Iridaceæ.

17. Amaryllidaceæ.

Subclass 2. - Dicotrledons. Flowers usually on the plan of 5 or 4 ; leaves netted-veined; cotyledons 2.

Apetalous division. Flowers with no corolla, and sometimes with no calyx.

Flowers monœcious or diœcious, one or both kinds in aments.

Staminate flowers in aments, the pistillate solitary or clustered.

Leaves pinnately compound . . . . 21. Juglandaceæ.

Leaves simple . . . . . . 25. Fagaceæ.

Both staminate and pistillate flowers in anfents.

Leaves alternate.

Fruits aggregated, fleshy _ . . . 27. Moraceæ.

Fruit a drupe . . . . . . . 22. Myricaceæ.

Fruit a capsule, seeds comose . . . 23. Salicaceæ.

Fruit a nut or samara . . . . . 24. Betulaceæ.

Leaves opposite, parasitic shrubs . . . 29. Loranthaceæ. 
Flowers not in aments, both calyx and corolla wanting.

Flowers monœeious, in globose heads, trees

55. Platanaceæ.

Flowers perfect, in slender spikes, herbs

20. Saururaceæ.

Flowers not in arnents ; calyx present, sometimes petaloid.

Trees or shrubs.

Ovary inferior

90. Cornaceæ.

Ovary superior.

Style single, entire, fruit a samara

99. Oleaceæ.

Style single, entire, fruit a drupe.

Anthers opening by valves .

44. Lauraceæ.

Anthers opening lengthwise

85. Thymeleaceæ.

Styles 2 or 2-cleft, fruit 1-celled

26. Ulmaceæ.

Styles 2 or 2-cleft, fruit 2-celled

73. Aceraceæ.

Woody twining vines; ovaries 3 .

Herbs.

Ovary inferior, 4-celled

Ovary inferior, 6-celled

42. Menispermaceæ.

Ovary superior, 1-celled.

Stipules none.

Stamens numerous

40. Ranunculaceæ.

Stamens few ; flowers with searious bracts

33. Amaranthaceæ.

Stamens few ; flowers without bracts .

Stipules sheathing the joints

32. Chenopodiaceæ.

31. Polygonaceæ.

Stipules not sheathing.

Style single

28. Urticaceæ.

Styles 2 .

27. Moraceæ.

Ovary superior, 3-celled

Ovary superior, 5-celled ; fruit a capsule

68. Euphorbiaceæ.

Ovary superior, 5-10-celled ; fruit a berry

51. Crassulaceæ.

34. Phytolaccaceæ.

Poimpetalous Division. Calyx and corolla both present, the petals not united

A. Stamens more than 10 .

Trees, shrubs, or woody vines.

Leafless, or nearly so ; stem fleshy

84. Cactaceæ.

Leaves alternate.

Ovary one, simple.

Fruit a drupe

Fruit a legume

58. Drupaceæ.

59. Mimosaceæ. 
Ovary one, compound; fruit dry.

Ovary 1-celled, with 3-5 parietal placentæ Ovary 5-celled, 1-2-seeded at maturity

81. Cistaceæ.

Ovary 5-celled, 3-10-seeded at maturity.

Stamens monadelphous

77. Tiliaceæ.

Stamens distinct

Ovary one, compound ; fruit fleshy

79. Theaceæ.

86. Lythraceæ.

57. Pomaceæ.

Ovaries numerous.

Leaves stipulate.

Stamens inserted on the receptacle

38. Magnoliaceæ.

Stamens inserted on the calyx

56. Rosaceæ.

Leaves not stipulate.

Small trees .

39. Anonaceæ.

Woody twining vines

42. Menispermaceæ.

Leaves opposite ; fruit dry.

Ovary single, 1-celled

80. Hypericaceæ.

Ovary single, 3-5-celled

52. Saxifragaceæ.

Ovaries several, enclosed by the calyx tube

Leaves opposite ; fruit fleshy, many-seeded Herbs.

Ovary single, simple; fruit a berry .

43. Calycanthaceæ.

86. Lythraceæ.

41. Berberidaceæ.

Ovaries several, simple.

Stamens inserted on the receptacle

40. Ranunculaceæ.

Stamens inserted on the calyx

56. Rosaceæ.

Ovary compound.

Aquatic herbs, leaves flat

37. Nymphæaceæ.

Marsh herbs, leaves tubular . . .

49. Sarraceniaceæ.

Terrestrial herbs.

Ovary 1-celled.

Placentæ central, juice watery

35. Portulacaceæ.

Placentæ central, juice milky or colored

45. Papaveraceæ.

Placentæ 2, parietal

47. Capparidaceæ.

Placentæ 3-6, parietal.

Leaves alternate

48. Resedaceæ.

Leaves opposite

80. Hypericaceæ.

Ovary several-celled, stamens monadelphous

78. Malvaceæ. 
B. Stamens not more than 10 .

Trees, shrubs, or woody vines.

Fruit a drupe.

Stamens 2, rarely 3-4

Stamens as many as the petals.

Flowers diøecious

Flowers perfect.

Stamens 4, alternate with the petals

Stamens 5, alternate with the petals

Stamens 4-5, opposite the petals

Stamens twice as many as the petals

Fruit a berry.

Stamens alternate with the petals.

Inserted on the calyx, leaves simple .

Inserted on the receptacle, leaves compound .

Stamens opposite the petals . . .

Fruit a 1-seeded samara . . . .

Fruit a 2-seeded capsule or samara.

Leaves simple

Leaves compound

Fruit a 3-5-celled capsule, leaves simple .

Fruit a 1-3-celled capsule, leaves compound .

Fruit a legume.

Stamens distinct

Stamens monadelphous or diadelphous

Herbs.

Ovary single, 1-celled, simple or compound.

Corolla regular, or nearly so.

Sepals and petals 4-5; stamens 5, distinct.

Leaves alternate.

$$
\begin{array}{lllllll}
\text { Stigma single } & . & . & . & . & . & . \\
\text { Stigmas } 4 . & . & . & . & . & . & . \\
\text { Stigmas 6-10 } & . & . & . & . & . & .
\end{array}
$$

Leaves opposite, flowers yellow . .

Leaves opposite, flowers white or red .

Sepals and petals 4-5; stamens 5, united Sepals 2, petals $4-5$. . . . .

Corolla irregular.

Fruit a legume

60. Cæsalpinaceæ.

52. Saxifragaceæ.

50. Droseraceæ.

80. Hypericaceæ.

36. Caryophyllaceæ.

83. Passifloraceæ.

35. Portulacaceæ.

61. Papilionaceæ. 
Fruit a capsule.

Stamens 5 . . . . . . . 82. Violaceæ.

Stamens 6, in 2 sets . . . . . . 45. Papaveraceæ.

Ovary single, 2-5-celled, fruit dry.

Ovary 2-celled.

Flowers in umbels, stamens 5

89. Umbelliferæ.

Flowers not in umbels, stamens 6 . 46. Cruciferæ.

Ovary a 4-celled capsule.

Calyx adherent to the ovary . . . 87. Onagraceæ.

Calyx enclosing the ovary, but not adher-

ent . . . . .

Ovary a 5-celled capsule.

Leaves simple.

Parasitic, capsule many-seeded

Terrestrial, capsule 5-10-seeded

92. Monotropaceæ.

62. Geraniaceæ.

Ovary single, 2-5-celled; fruit a berry . . $\quad$ 88. Araliaceæ.

Ovaries 2, seeds comose . . . . . 103. Asclepiadaceæ.

Gamopetalous Division. Calyx and corolla both present, the petals more or less united.

Trees, shrubs, or woody vines.

Leaves alternate.

Fruit dehiscent.

Fruit a legume

61. Papilionaceæ.

Fruit a 3-celled capsule . . . . . 91. Clethraceæ.

Fruit a 5-celled capsule . . . . 93. Ericaceæ.

Fruit indehiscent, dry.

Fruit drupe-like, 1-seeded . . . . 97. Symplocaceæ.

Fruit ovoid and winged or globose and

1-2-seeded . . . . . . . 98. Styracaceæ.

Fruit 2-3-celled, 2-3-seeded . . . . . 70. Cyrillaceæ.

Fruit a drupe . . . . . . 71. Ilicaceæ.

Fruit a berry.

Ovary superior; seeds few, large . . . 96. Ebenaceæ.

Ovary superior; seeds many, small . . 110. Solanaceæ.

Ovary inferior . . . . . . 94. Vacciniaceæ.

Leaves opposite.

Fruit a 2-celled, 2-seeded capsule . . . . 117. Rubiaceæ.

Fruit a 2-celled, many-seeded capsule.

Seeds winged . . . . . . . 113. Bignoniaceæ. 
Seeds not winged; shrubs .

118. Caprifoliaceæ.

Seeds not winged ; twining vines . . 100. Loganiaceæ.

Fruit a 5-celled capsule . . . . . 93. Ericaceæ.

Fruit a drupe or berry.

Fruit 1-2-seeded ; stamens 2 . . . 99. Oleaceæ.

Fruit 1-4-seeded ; stamens 4 . . . 108. Verbenaceæ.

Fruit 1-5-seeded ; stamens 5 . . . 118. Caprifoliaceæ.

Herbs.

Ovary superior, flowers regular.

Ovary separating into 2 distinct follicles.

Style single, stamens distinct . . . 102. Apocynaceæ.

Styles 2, stamens united . . . . 103. Asclepiadaceæ.

Ovary 1-celled.

Fruit a legume . . . . . . 59. Mimosaceæ.

Fruit a capsule.

Leaves alternate.

Stamens opposite the lobes of the corolla

95. Primulaceæ.

Stamens alternate with the lobes of the corolla

106. Hydrophyllaceæ.

Leaves opposite . . . . . . 101. Gentianaceæ.

Ovary 2-several-celled.

Stamens 2 or 4 . . . . . . 116. Plantaginaceæ.

. Stamens 5, cells of the ovary 1-2-seeded.

Fruit separating into 4 nutlets

107. Boraginaceæ.

Fruit a capsule . . . . . . 104. Convolvulaceæ.

Stamens 5 , cells of the ovary severalseeded.

\section{Stigma 1}

Stigmas 2

Stigmas 3
110. Solanaceæ.

100. Loganiaceæ.

105. Polemoniaceæ.

Ovary superior, flowers irregular.

Ovary 1-celled.

Fruit a legume

61. Papilionaceæ.

Fruit a capsule

Ovary 2-4-celled.

Cells each 1-seeded.

Ovary deeply 4-lobed

109. Labiatæ.

Ovary not deeply lobed.

Stamens 2 or 4

108. Verbenaceæ.

Stamens 8

67. Polygalaceæ. 
Cells each 2-several-seeded.

Fruit with a long curved beak . . 114. Martyniaceæ.

Fruit not prominently beaked.

Corolla lobes imbricated in the bud . 111. Scrophulariaceæ.

Corolla lobes convolute in the bud . 115. Acanthaceæ. Ovary inferior.

Flowers in an involuerate head.

Juice milky . . • • • . . 122. Cichoriaceæ.

Juice watery or resinous . - . . 123. Compositæ.

Flowers not in heads.

Stamens 3.

Leaves alternate . . . . . 120. Cucurbitaceæ.

Leaves opposite . . . . . . 119. Valerianaceæ.

Stamens 4-5.

Leaves alternate . . . . . 121. Campanulaceæ.

Leaves opposite or whorled . . . 117. Rubiaceæ. 


\section{CLASS I. GYMNOSPERM}

Plants without a closed ovary, style, or stigma; seeds produced between dry or fleshy scales which are borne in small spikes or clusters, and which form a cone or berry; cotyledons usually three or more.

\section{PINACE $Æ$. PINE FAMILY.}

Trees or shrubs ; wood of disk-bearing tissue, without ducts ; juice resinous; leaves mostly evergreen, filiform, linear or scale-like; flowers monœcious or diœcious, destitute of calyx and corolla; staminate flowers each consisting of a catkin-like spike, the stamens several in a cluster, with scale-like bracts; ovules solitary or several on the upper surface of a scale which usually has a small bract at its base, the scales maturing into a woody or papery cone or a fleshy berry.

\section{PINUS.}

Trees; leaves of two kinds, the earlier thin, chaffy, and scale-like, the later from the axils of the earlier, 2-5 in a cluster, their bases enclosed in a persistent, scarious sheath, evergreen, needle-like, 1-15 in. long; flowers monœecious; staminate ones clustered at the base of shoots of the present season; the stamen clusters arranged spirally, each in the axil of a scale-like bract; filaments very short; pistillate flowers on twigs of the previous season, in small clusters or sometimes solitary, consisting of deciduous bracts spirally arranged, and in the axil of each bract a scale bearing at its base on the upper surface two ovules; scales becoming thickened and woody, forming a cone at maturity; seeds winged.

1. P. palustris Mill. Long-Leaved Pine. A large tree; bark thin-scaled, wood very resinous, old trees with only a few spreading 
branches near the top; leaves in 3 's, $10-15 \mathrm{in.}$ long; sheaths $1-1 \frac{1}{4}$ in. long, crowded near the ends of very scaly twigs; staminate aments 2-3 in. long, bright purple, conspicuous ; cones terminal, oblongconical, 6-10 in. long, diameter 2-3 in. before opening, 4-6 in. when fully opened; scales much thickened at the apex and armed with a short recurved spine at the end. February-March. The most common tree in the pine barrens; wood hard, strong, and durable, especially valuable for floors and inside work.

2. P. Virginiana Mill. Scrub Pine. A small tree, usually 20-30 ft. high, but sometimes much taller; bark of the trunk rough, nearly black; twigs smooth and glaucous ; leaves in 2's, 1-2 in. long, rigid, sheaths very short; staminate aments dull yellowish purple, 1 in. long; cones solitary, short peduncled, often reflexed, oblongconic, about 2 in. long; scales thickened at the apex and armed with a slender straight or recurved prickle. April-May. On dry, sandy soil; wood light, soft, weak, and of little value.

3. P. Thed L. Loblolly Pine, Oldfield Pine. A large tree; bark very thick and deeply furrowed, becoming flaky with age; twigs scaly ; leaves in 3's, 6-10 in. long, slender, very flexible ; sheaths $\frac{2}{3}-1$ in. long; cones solitary, oblong-conical, $3-5$ in. long; scales thickened at the apex, the transverse ridge very prominent and armed with a short, stout, straight, or recurved spine. MarchApril. Common and often springing up in old fields; trunk containing a large proportion of sap wood; timber of little value for outside work.

\section{TAXODIUM.}

Trees; leaves spreading so as to appear 2-ranked, deciduous; flowers monœecious, appearing before the leaves; staminate ones numerous, globose ; forming long, terminal, drooping, panicled spikes; anthers 2-5-celled; pistillate flowers single or in pairs, bractless, the peltate scales 2-ovuled; cone globose; the very thick woody scales angular, separating at maturity; seeds 3 -angled, pyramidal.

T. distichum (L.) Rich. Bald Cypress. A very large tree; bark dark brown, rough, fibrous ; many of the twigs deciduous with the leaves; leaves alternate, opposite or whorled, distichous, flat, linear, $\frac{1}{2}-\frac{3}{4}$ in. long; cones terminal, globose, about 1 in. in diameter; ends of the scales much thickened, rugose and with a distinct triangular marking. February-March. Common in swamps and on the borders of streams; wood reddish, soft, light; specially valuable for shingles and fence posts, and for boat building. 


\section{JUNIPERUS.}

Trees or shrubs; leaves subulate or scale-like, often both forms on the same tree, evergreen, sessile, opposite or verticillate; flowers diœcious or sometimes monœcious; staminate ones lateral or terminal, of few stamens, oblong or ovoid; pistillate flowers of a few opposite or verticillate fleshy scales; each scale 1-2-ovuled; cone globose, berry-like.

J. Virginiana L. Red Cedar. A tree with spreading branches and dark brown fibrous bark; leaves opposite or in 3 's ; all of those on young trees and some of those on older trees subulate and spreading, the others scale-like and closely appressed; aments terminal, berry-like; cones light blue with a distinct bloom, about $\frac{1}{4}$ in. in diameter, 1-2-seeded. March-April. A very common tree; the heart wood reddish, light, strong, fragrant; the principal wood used in the manufacture of lead-pencils.

\section{CLASS II. ANGIOSPERM E.}

Plants producing seeds in a closed ovary formed from one or more modified leaves; cotyledons 1 or 2 .

\section{SUBCLASS I. MONOCOTYLEDONS.}

Stems with the fibro-vascular bundles scattered irregularly through the parenchyma mass, not in rings, no distinction between bark, wood, and pith ; leaves usually parallel-veined, alternate and entire; parts of the flower usually in 3 's or 6 's, never in 5 's ; cotyledon single.

\section{TYPHACE $Æ$. CAT-TAIL FAMILY.}

Perennial marsh or aquatic plants; rootstock stout, creeping; stem simple, terete, erect; leaves simple, strap-shaped, sheathing at the base, nerved and striate; flowers monœcious, in a single terminal spike, staminate part of the spike uppermost, each part subtended by spathe-like deciduous bracts; 
perianth of fine bristles; staminate flowers sessile; stamens $2-7$; filaments connate, subtended by minute bracts; pistillate flowers short-pediceled; ovary 1-2-celled; styles 1-2; fruit small, nutlike.

\section{TYPHA.}

\section{- Characters of the family.}

T. latifolia L. Cat-tail. Stem erect, jointed below, 5-8 ft. high; leaves nearly as long as the stem, about 1 in. wide, reticulated and glaucous; spike cylindrical, dark brown or black; staminate and pistillate portions usually without any interval between them, each 4-8 in. long and about $1 \mathrm{in}$. in diameter; fruit furrowed. JuneAugust. Common in marshes and shallow ponds.

\section{ALISMACEA. WATER-PLANTAIN FAMILY.}

Annual or perennial marsh herbs, usually with creeping runners or rootstocks; stems scapose; leaves long-petioled, sheathing at the base; petiole rounded; blade nerved, reticulated, or sometimes wanting; flowers in racemes or panicles, perfect, monœcious, or diœcious; pedicels in bracted whorls; sepals 3 , persistent, petals 3 or wanting; stamens 6 or more, ovaries few or many, 1-celled, 1-seeded; style short or none; fruit a 1-seeded achene.

\section{ALISMA.}

Annual or perennial herbs, leaves erect or floating, blades prominently ribbed and reticulated, or even pinnately veined; scapes erect, becoming longer than the leaves, terete, spongy ; flowers perfect, in paniculate 3-bracted umbels, small, white or pink ; stamens 6-9; ovaries numerous in one or more whorls on a flat receptacle; fruit 1-seeded achenes which are ribbed on the back and sides.

A. Plantago-aquatica L. Water Plantain. Perennial; root fibrous; leaves ovate or somewhat cordate, 5-7-nerved when erect, floating leaves narrower and sometimes linear; scapes usually single; panicle 1-2 ft. long; flowering branches whorled, subtended by three narrow, striate bracts ; pedicels slender, elongated; ovaries 
15-20 in a single whorl; base of the short style persistent, forming a beak at the inner angle of the achene; achenes obliquely obovate, $2-3$-keeled on the back. June-September. Common in ponds and muddy places.

\section{SAGITTARIA.}

Perennial; rootstocks mostly nodose or tuber-bearing; scapes erect or decumbent; leaves long-petioled, sheathing at the base, the blade nerved and reticulated or wanting; flowers monœecious or diœcious, racemed in 3-bracted whorls of 3's, the upper flowers usually staminate; sepals 3, persistent; petals 3, withering-persistent or deciduous; stamens few or many; ovaries in globose heads, 1-ovuled; style short, persistent; fruit a subglobose head of flattened achenes.

1. S. Latifolia Willd. Broad-Leaved Arrowhead. Leaves very variable in size and shape, from broadly sagittate to linear; those growing on the drier soil being usually the broader; petioles 6-30 in. long, scape smooth or slightly pubescent, 6-36 in. high; bracts acute; flowers monœecious or sometimes diøecious, white, 1 in. or more in width; pedicels of the staminate flowers twice the length of those of the fertile flowers ; filaments long, smooth, and slender; achenes compressed, obovate, winged ; beak nearly horizontal. JuneSeptember. Ditches and muddy places.

2. S. graminea Michx. Grass-leaved Sagittaria. Leaves long-petioled, lanceolate, or elliptical, and acute at each end, 3-5nerved, or often linear, the earlier often reduced to phyllodia; scape slender, usually longer than the leaves, simple, weak, often prostrate in fruit ; bracts small, ovate, connate at the base; flowers moncecious or diøecious, on long, filiform pedicels, about $\frac{1}{2}$ in. wide; stamens 10-20, filaments pubescent, achenes obovate, wing-keeled, nearly beakless. May-October. In ditches and shallow pools.

\section{GRAMINEA. GRASS FAMILY.}

Annual or perennial herbs, sometimes slender trees; stems rounded, often grooved on one side, usually hollow, closed and enlarged at the nodes; leaves 2-ranked, with sheathing bases which are usually split on the side opposite the blade but are sometimes entire; the orifice of the sheath usually crowned with a scarious ring called a ligule; inflorescence in 
spikes, racemes, or panicles ; flowers in spikelets consisting of 2-ranked imbricated scales or glumes, the two lower usually empty, the others subtending the flower which is enclosed in a scale-like palet; the upper flower in the spikelet often staminate or only an empty palet, or even an abortive pedicel; flowers perfect or monœcious, rarely diœcious ; stamens 1-6, usually 3 ; ovule 1 ; styles $1-3$, usually 2 ; seed a caryopsis or grain.

A large family, of which there are more than 800 species in the United States, including corn, wheat, rye, oats, rice, sorghum, sugar cane, and many other culti-

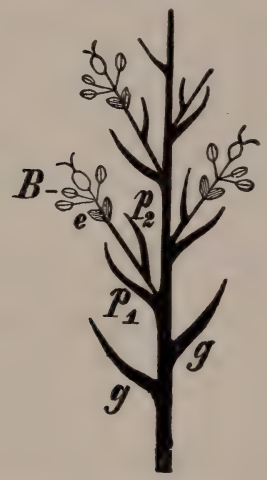

FrG. 210. - Diagram of Inflorescence of a Grass.

$g$, sterile glumes ; $P_{1}$, a flowering glume ; $P_{2}$, a sealy bract (palet); $e$, transparent seales (lodicules) at the base of the flower; $B$, the flower.

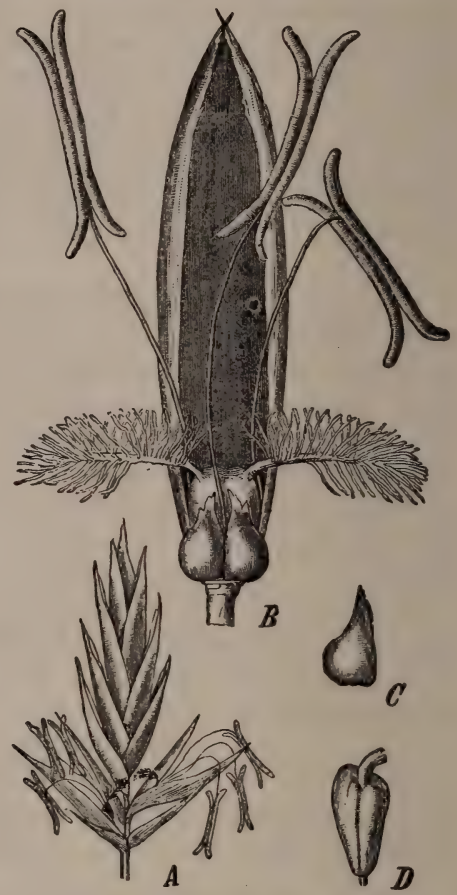

Fig. 211. - Fescue-Grass (Festuca pratensis).

$A$, spikelet (compare Fig. 210); $B$, a flower, the lodicules in front and the palea behind ; $C$, a lodicule ; $D$, ovary.

vated sorts. The cane, Arundinaria macrosperma, is the only tree-like species found in this country.

[The identification of the species is too difficult for the beginner, but the structure of the spikelets and the separate flowers may be learned by a study of Figs. 210, 211.] 


\section{CYPERACEF. SEDGE FAMIIY.}

Annual or perennial herbs; grass-like or rush-like ; stems mostly 3-angled, solid, leaves 3-ranked, grass-like, with closed sheaths; flowers in spikes or spikelets, perfect or imperfect,

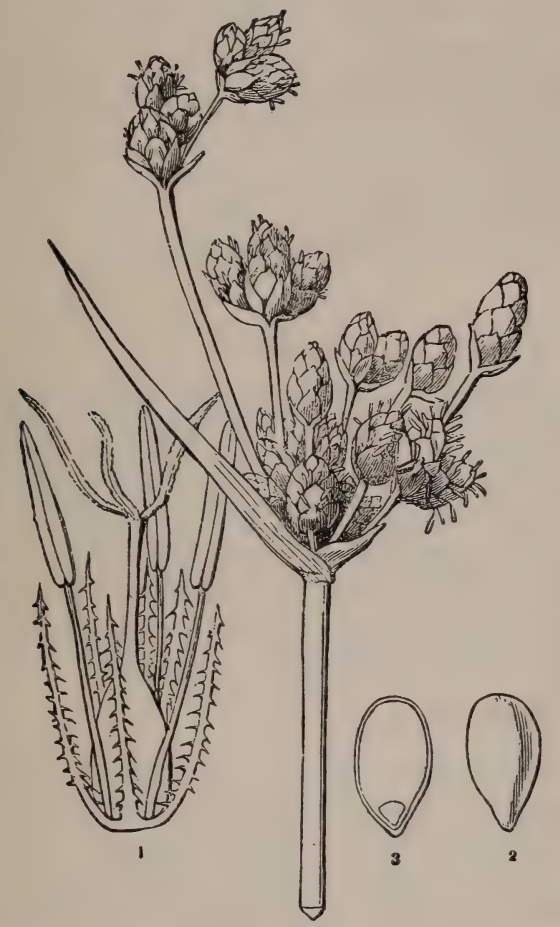

Fig. 212. - Inflorescence, Flower and Seed of a Sedge.

(Great Bulrush, Scirpus lacustris.)

1, magnified flower, surrounded by a perianth of hypogynous bristles ; 2 , the seed; 3 , section of the seed, showing the small embryo enclosed in the base of the albumen.

each in the axil of a scale-like bract; perianth often a row of minute scales or bristles ; stamens usually 3 ; ovary 1-celled, style 2-3-cleft or rarely simple ; fruit a flattened or 3-angled achene. 
A large family, mostly growing in tufts in wet places, few species being of any value. Fig. 212 shows a common form of inflorescence, and an achene with its perianth of bristles.

\section{SABALACE E. PALM FAMILY.}

Trees or plants with woody creeping stems or nearly acaulescent, leaves petioled, pinnate or palmate, plaited in the bud, flowers perfect or polygamous, on a spadix which is often branching or paniculate; sepals and petals 3 , more or less united, persistent ; stamens usually 6 ; ovary 3 -celled, 3 -ovuled ; styles 3 , distinct or united, stigma entire, fruit a drupe or berry.

\section{SABAL.}

Stem short, erect, or decumbent, usually simple; leaves long-petioled, nearly orbicular in outline, deeply parted, the divisions 2-cleft at the apex and often with thread-like filaments in the sinuses; sheaths of the leaves usually of dry interlaced fibers; spadix long and branching, with sheathing spathes at the joints; flowers perfect, sessile, each in the axil of a small bract; perianth cup-shaped; petals distinct; stamens 6, filaments distinct; styles 3, united, 3-angled; stigma capitate, fruit a drupe.

S. Andersonit Guerns. Dwarf Palmetto. Stem short, mostly buried in the earth; leaves orbicular, glaucous, divisions slightly cleft at the apex, filaments few ; petiole usually shorter than the leaf, crescent-shaped in cross-section, edges smooth ; spadix erect, slender, taller than the leaves, 4-6 ft. high, paniculately much branched; drupe black, globose, $\frac{1}{3}$ in. in diameter. June-July. Low grounds, Central Louisiana to North Carolina and southward.

\section{SERENOA.}

Stems creeping, widely branched; leaves orbicular, longpetioled, at the apex of the branches, divisions slightly cleft at the apex, thread-like filaments none; spadix short, flowers perfect, sessile, bracted; petals slightly united; stamens 6 , distinct; style slender; fruit a drupe. 
S. serrulata B. \& H. Saw Palmetto. Stems creeping widely, often covering spaces $20 \mathrm{ft}$. in diameter; leaves bright green; petiole plano-convex in cross-section, toothed on the edges; spadix much shorter than the leaves, densely tomentose; style slender; drupe ovoid or oblong, black, $\frac{2}{3}-\frac{3}{4}$ in. long. May-July. On sandy soil near the coast.

\section{RAPHIDOPHYLLA.}

Stem short, thick, erect; leaves long-petioled, fan-shaped, deeply palmately divided, without filaments in the sinuses; sheath persistent, soon dry and net-like, with numerous strong, erect, black spines; spadix branched, densely flowered; spathes 2-4-leaved; flowers yellowish, bracted; calyx 3-cleft; petals distinct; stamens $6-9$, united at the base ; ovaries 3 , more or less united; drupes 1-3, 1-seeded.

R. hystrix W. \& D. Blue Palmetto. Stem short, erect, often proliferous; leaves triangular, fan-shaped to orbicular, very deeply cleft, the divisions 2-4-toothed, blue-glaucous; petioles mostly longer than the leaves, triangular in cross-section, rough-edged above; spadix small, short-peduncled, widely branched, 6-12 in. long; spathes woolly, partial spathes none; fruit an ovoid drupe, $\frac{1}{2}-\frac{3}{4}$ in. long. June-July. Low, shady woods. Central Mississippi to South Carolina and southward.

\section{ARACEA. ARUM FAMILY.}

Perennial herbs, mostly acaulescent, growing from a corm or a creeping rootstock; juice acrid; leaves simple or compound, usually long-petioled and netted-veined, but sometimes strap-shaped and parallel-veined; flowers on a spadix, generally enclosed in a spathe, usually the staminate above and the pistillate below, but in some species perfect or diœcious; calyx and corolla wanting or the former of 4-6 small scales; stamens 4-10, short; ovary 1-several-celled, 1-several ovules in each cell; stigma sessile; fruit indehiscent, a berry or utricle.

\section{ARIS ÆMA.}

Corms very acrid, black; leaves usually 1-3, palmately divided; petioles long and sheathing the scape which bears 
the spadix at its summit; spathe convolute below, usually dilated and arched above, withering persistent; spadix bearing the monœcious or diœcious flowers at its base, the apex sterile and naked; perianth none; stamens 4 in a whorl, nearly sessile; ovaries 1-celled, 1-6-ovuled; stigma sessile; fruit a 1-few-seeded red berry.

1. A. triphyllum (L.) Torr. Indian Turnip. Leaves 2, trifoliate, leaflets sessile, oval or ovate, acuminate, entire, netted-

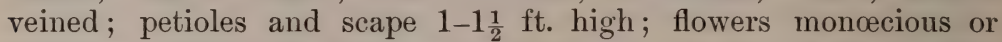
dioecious; spathe dilated above, arched over the top of the spadix, green with purple stripes on the inside; spadix club-shaped, floriferous below; stamens very short; ovaries crowded, ovules 4-6; fruit bright scarlet, forming an ovoid head about 1 in. long. MarchApril. In rich woods.

2. A. Dracontium (L.) Schott. Dragon Root. Corms several; leaf usually solitary, petiole 1-3 ft. high, enclosed by membranous sheaths, leaf pedately divided into $7-15$ segments which are nearly or quite sessile, oblong or oblanceolate, usually acute at the apex, entire or the lower ones lobed; scape sheathed at the base, usually shorter than the petiole; spathe light green, convolute, acuminate, 1-2 in. long; spadix slender, tapering to a slender point, 4-7 in. long, flower-bearing only in the part enclosed by the spathe; fruit reddish orange, 1-3-seeded, in a large ovoid head. March-April. In rich woods.

\section{PELTANDRA. .}

Perennial marsh herbs with creeping rootstocks; leaves sagittate, acute, entire, the base of the petioles sheathing the rootstock; scape shorter than the petiole; spathe elongated, thick and fleshy; flowers monœcious, covering the entire spadix, staminate flowers above; perianth none; stamens $5-10$, imbedded in a peltate, shield-like connective which finally shrivels so as to leave the anthers free; ovaries imbedded in the spadix, surrounded by a few abortive stamens; ovules 1 or few ; style short; stigma capitate ; fruit 1-3-seeded, green or red berries forming a globose head partially enclosed by the base of the spathe; seeds enclosed in a gelatinous coating.

P. Virginica (L.) Kunth. Green Arrow-Arum. Leaves several, sometimes $2 \mathrm{ft}$. long, prominently and finely veined with $2-3$ intra-marginal nerves; scape nearly as long as the petiole, recurved 
in fruit; spathe green, lanceolate, convolute its entire length, longer than the spadix, the upper part withering; berries green, 1-seeded. April-May. In marshes and wet woods.

\section{ORONTIUM.}

Perennial aquatic herbs, with stout rootstocks buried in the mud; leaves petioled, oval, entire, nerved; spathe enclosing the spadix only in the bud, soon deciduous; flowers perfect, yellow, covering the entire spadix ; sepals 4-6, scale-like ; stamens 4-6; ovary 1-celled, 1-ovuled, stigma sessile; fruit a green utricle.

O. Aquaticum L. Golden Club. Leaves ascending or floating, very dark green and velvety-looking above, paler beneath, petioles stout, 6-18 in. long; scape stout, thickened above, curved, about as long as the petiole; flowers bright yellow; utricle depressed-globose, tuberculate above. March-April. In slow-flowing streams and shallow ponds.

\section{BROMELIACE $Æ$. PINE-APPLE FAMILY.}

Herbs, mostly epiphytic or partly parasitic; whole plant scurfy; stem rigid or flexuous; leaves very slender, often rigid; flowers perfect, regular, spiked, panicled or solitary, bracted; sepals 3, distinct or united; petals 3 , distinct or united; stamens 6 ; ovary superior or inferior, 3-celled, placentæ central, style 1 , stigmas 3 ; fruit fleshy or a 3-celled, 3-valved, many-seeded capsule.

\section{TILLANDSIA.}

Epiphytic or partly parasitic herbs; stem rigid and erect or filiform and pendulous; leaves slender, often filiform; sepals rigid; petals spreading above, claw long; stamens filiform, hypogynous; ovary free, style slender; fruit a 3-valved, many-seeded capsule.

T. usneoides L. Spanish Moss. Perennial, epiphytic or partly parasitic; stem filiform, branching, gray-scurfy, with a black core like horsehair, 2-10 ft. long; leaves filiform, alternate in small fas- 
cicles, sheathing at the base; flowers axillary with conspicuous bracts; sepals distinct or nearly so, green; petals distinct, linear, recurved, greenish-yellow ; capsule linear, about 1 in. long, splitting into 3 valves; seeds on a long funiculus which at maturity splits in a coma-like tuft. June-September. On living trees, more common southward. The hair-like core of the stem often used as a substitute for curled hair in making mattresses, cushions, etc.

\section{COMMELINACEA. SPIDERWORT FAMILY.}

Annual or perennial herbs, with viscid or mucilaginous juice; stems somewhat succulent, jointed, leafy, simple or branched; leaves simple, succulent, narrow, entire, sheathing at the base, sheaths entire or split; flowers in terminal cymes or umbels, perfect, often irregular ; sepals 3 , persistent, foliaceous or colored; petals 3 , fugacious or deliquescent ; stamens 6 or fewer, often some of them abortive; ovary free, $2-3$-celled, style single, stigma entire or 3-lobed; fruit a 2-3-celled, 2-3valved capsule; seeds solitary or several in each cell.

\section{COMMELINA.}

Annual or perennial; stem branching, erect or procumbent, smooth or pubescent; leaves petioled or sessile, entire, the floral ones cordate, folded and forming a spathe enclosing the base of the cyme; flowers irregular ; sepals mostly colored, 1 of them smaller; petals blue, unequal, 2 of them reniform and long-clawed, the other smaller; stamens 6 , only 3 of them fertile, filaments smooth; capsule 1-3-celled; seeds 1-2 in each cell.

1. C. hirtella Vahl. Bearded Dayflower. Stem stout, erect, 2-3 ft. high; leaves lanceolate or oblong, acuminate, roughhairy above, sheaths $\frac{3}{4}-1$ in. long, fringed with brown hairs; spathes numerous, sessile or short-stalked; petals nearly alike, the odd one smaller ; capsule 5-seeded; seeds brown, smooth. August-September. In moist and shaded soil.

2. C. Virginica L. Virginia Dayflower. Stem erect, pubescent, 1-2 ft. high ; leaves lanceolate to oblong-lanceolate, acuminate, $3-5$ in. long, somewhat rough above, sheaths inflated, hairy, the orifice often fringed; spathes containing a viscid secretion ; flowers 
1 in. wide, the odd petal lanceolate ; capsule 3 -seeded, the dorsal cell indehiscent. May-September. On moist sandy soil.

\section{TRADESCANTIA.}

Perennial; stem simple or branched; leaves very narrow; flowers in terminal and axillary bracted umbels, regular, 1 in. broad; sepals 3 , herbaceous ; petals 3 , fugacious or deliquescent; stamens 6 , sometimes 3 shorter than the others, filaments bearded or smooth; ovary 3-celled, with 2 ovules in each cell; pedicels recurved in fruit ; capsule 3-celled, 3-valved, 3-6-seeded.

1. T. Virginica L. Spiderwort. Stem erect, stout, smooth or villous, 1-2 ft. high ; leaves linear, keeled, often purple-veined, long-acuminate, $1 \mathrm{ft}$. or more in length ; bracts similar to the leaves, umbels sessile, 2-many-flowered, flowers in 2 rows in the bud; petals blue or purple, twice as long as the sepals; stamens blue, filaments densely bearded; capsule ovoid or oblong. March-June. On dry sandy soil.

2. T. pilosa Lehm. Hairy Spiderwort. Stem stout, erect or flexuous, branched, villous or nearly smooth, 1-2 ft. high;. leaves linear-oblong, acuminate at the apex, narrowed at the base, pubescent on both sides; umbels axillary and terminal, many-flowered; pedicels and sepals villous with glandular hairs; flowers blue or purple, $\frac{3}{4}-1$ in. wide; seeds pitted. May-July. In rich soil.

\section{PONTEDERIACE A. PICKEREL-WEED FAMILY.}

Perennial marsh or aquatic herbs ; stems simple or branched, succulent; leaves simple, alternate ; flowers solitary or spiked, each subtended by a leaf-like spathe, perfect, mostly irregular, perianth corolla-like, 6-parted; stamens 3 or 6 , unequal, inserted irregularly in the tube or throat of the perianth; ovary free, style single, stigma entire or toothed; ovary 1- or 3-celled; fruit a 1-seeded utricle.

\section{PONTEDERIA.}

Stem erect, from a thick creeping rhizome, bearing a single leaf above the middle and several sheathing bract-like leaves 
at its base, radical leaves numerous, thick, parallel-veined; petiole long, from a sheathing base; flowers in terminal spikes, perianth 2-lipped, lobes of the upper lip ovate, of the lower, oblong, spreading; stamens 6 , the three upper short and often imperfect, the three lower exserted; ovary 3-celled, but only 1 cell ovule-bearing; the 1-seeded utricle enclosed by the base of the perianth.

P. cordata L. Pickerel-weed. Stem stout, erect, 2-4 ft. high; leaves long, from cordate to lanceolate and often hastate, apex and basal lobes obtuse, finely nerved; spike dense, 2-4 in. long, peduncles enclosed by the spathe; perianth hairy, blue, the upper lip with two yellow spots, tube 6-ribbed, curved, rather longer than the lobes; ovary oblong. June-September. In ponds and slow streams.

\section{JUNCACEÆ. RUSH FAMILY.}

Grass-like perennial or annual herbs, mostly growing on wet soil; stems mostly erect but sometimes creeping, simple or branched, naked or leafy and jointed; leaves terete, sheathing at the base, very slender and pointed or flattened and grass-like; flowers in cymes or panicles which may be very loose and spreading, or so compact as to form a head, sometimes with a rigid scape prolonged beyond the flower cluster; flowers usually bracted, perianth of 6 nearly equal scale-like persistent divisions; stamens 3 or 6 , inserted on the base of the perianth; ovary free, 1 - or 3-celled, many-ovuled, style single, stigmas 3 , usually hairy ; fruit a 1- or 3-celled, 3-manyseeded capsule.

[Most species flower late in the season, and their identification is too difficult for one without considerable experience.]

\section{MELANTHACEÆ. COLCHICUM FAMILY.}

Perennial herbs, usually from a stout rootstock; stem simple or branched, leafy; leaves parallel-veined, often with transverse veins, broad or narrow and grass-like; flowers solitary, 
racemose, or panicled, regular, perfect, polygamous, or diœcious, perianth of 6 similar and usually distinct segments; stamens 6 , rarely 9-12, inserted on the base of the perianth; ovary free or nearly so, 3-celled, many-ovuled, styles 3 , distinct or partly united; fruit a capsule, seeds usually winged or tailed.

\section{CHAM ÆLIRIUM.}

Rootstock short and thick, bitter ; stem simple, erect, leafy, glabrous; lower leaves spatulate to obovate, the stem leaves narrower; flowers small, white, in a spike-like raceme, diœcious, perianth of 6 linear-spatulate segments ; stamens 6 , filaments longer than the perianth; ovary 3 -celled, styles 3 ; fruit an ovoid, 3-angled, many-seeded capsule.

C. Luteum (L.) Gray. Unicorn-root. Stem furrowed, staminate plants 1-2 ft. high, pistillate taller, often $3 \mathrm{ft}$. or more; lower leaves obovate, clustered, the upper small and bract-like; staminate racemes slender and drooping, the pistillate erect; flowers short pediceled; capsule 3-valved, seeds linear-oblong, winged at the ends. May-June. On low ground.

\section{CHROSPERMA.}

Stem simple, glabrous, erect from a bulbous base; leaves long and slender; flowers white, in a simple terminal raceme, perfect, perianth of 6 segments which are sessile and glandless; stamens 6 , inserted in the base of the perianth; ovary 3-lobed, 3-celled; fruit a dehiscent 3-lobed capsule, the lobes becoming subulate by the persistent style bases; cells fewseeded.

C. muscetoxicum (Walt.) Kuntze. Fly Poison. Bulb ovoid or oblong; stem somewhat angled below, 1-3 ft. high ; lower leaves strap-shaped, channeled, the upper small and bract-like; raceme dense, cylindrical; pedicels from the axils of minute ovate bracts, perianth segments ovate, white, becoming greenish, nearly as long as the slender stamens; styles spreading; capsule with divergent lobes ; seeds ovoid, red. May-June. In rich woods. 


\section{UVULARIA.}

Stem slender, branching, erect from a slender, creeping rootstock; leaves alternate, sessile, or perfoliate; flowers terminal, usually solitary, peduncled, drooping, perianth bellshaped or funnelform, segments 6 , distinct, with nectar-bearing glands at the base within, deciduous; stamens 6 , short; ovary 3 -lobed, 3 -celled, style deeply 3 -parted, stigmas spreading ; fruit a 3-angled or 3-winged, dehiscent capsule, seeds $1-3$ in each cell.

1. U. perfoliata L. Perfoliate Bellwort. Stem glabrous, pale green, forked or branched above the middle, 10-20 in. high; leaves ovate or oblong, acute at the apex, perfoliate at the base, entire, glaucous beneath, the sides revolute when young ; flowers pale yellow, about $1 \mathrm{in.} \mathrm{long,} \mathrm{segments} \mathrm{lanceolate,} \mathrm{granular-roughened}$ within ; stamens about the length of the style ; capsule obovoid, truncate, the angles grooved. April-May. In moist woods.

2. U. GRANDiflora Smith. LARGe-Flowered Bellwort. Stem slender, nearly leafless below the fork, glabrous, 12-24 in. high; leaves ovate or oblong, acute at the apex, perfoliate at the base, entire, smooth above, pubescent below ; flowers bright yellow, $1 \frac{1}{4} \mathrm{in}$. long, segments linear-lanceolate, smooth within ; stamens longer than the styles; capsule obovate, truncate, obtusely angled. April-May. In rich woods. More common northward.

3. U. Sessilifolia L. Sessile-Leaved Bellwort. Stem slender, erect, glabrous, few-leaved below the fork, 6-12 in. high; leaves lanceolate-oblong, thin, acute at each end, margins rough, smooth on both sides, sessile; flowers greenish-yellow, $\frac{3}{4}$ in. long, perianth segments lanceolate, obtuse, smooth within; stamens shorter than the style; capsule stalked, wing-angled. April-May. In rich woods.

\section{LILIACEÆ. LILY FAMILY.}

Herbs, or woody plants, the herbaceous species mostly from bulbs or corms; leaves sessile or sheathing, parallel-nerved, but often with netted veins ; flowers clustered or solitary, perfect, regular; perianth corolla-like, 6-parted, rarely 4-parted, the segments distinct or partially united into a tube ; stamens 6 , hypogynous or perigynous; ovary 3-celled, many-ovuled, 
style 1 , stigmas 3 , distinct or united ; fruit a capsule or berry, few-many-seeded.

Plants from fibrous roots.

Stem herbaceous.

Flowers in corymbs or panicles . .

Flowers in spikes .

\section{Stem woody}

Plants from corms

Plants from bulbs.

Bulbs coated.

Flowers in umbels .

Flowers in corymbs

Bulbs scaly.

Flowers solitary or in corymbs

Flowers in spikes
I. Hemerocallis.

VII. Aletris.

VIII. Yucca.

V. Erythronium.

\section{HEMEROCALLIS.}

Perennial, from a fascicle of fleshy roots; stem erect, branched, glabrous; leaves mostly basal and linear; flowers on branching scapes, large, yellow or orange, solitary or corymbed, perianth funnelform with a spreading limb much longer than the tube; stamens 6 , inserted in the top of the tube, shorter than the lobes, curved upward; ovary 3-celled, many-ovuled, style longer than the stamens, curved upward, stigma capitate; fruit a 3-celled, 3-angled capsule.

H. Fulva L. Day Lily. Scapes stout, branched above, with a few bract-like leaves, smooth, 3-5 ft. high; leaves very long, strap-shaped, acute, channeled ; flowers short-pediceled, tawny-yellow, perianth lobes oblong, netted-veined, flowers lasting only one day. May-June. Introduced from Asia and common in old gardens.

\section{ALLIUM.}

Acaulescent herbs from coated bulbous roots with the characteristic odor of onions; bulbs solitary or clustered; leaves narrowly linear or slender-tubular, glaucous; flowers in terminal umbels on naked scapes, the umbels often bracted or enclosed in a spathe, flowers small on slender pedicels, perianth 6-parted, persistent; stamens 6 , inserted on the base 
of the perianth, filaments filiform or dilated below; ovary sessile, 3-celled, style filiform, jointed, stigma entire; fruit a 3-celled, 3-valved, few-seeded capsule. Flowers sometimes changed into bulblets.

1. A. Canadense L. Meadow Garlic. Bulbs ovoid, the outer coats of white and scarious reticulating fibers; leaves narrowly linear, flat, or concave above; scape terete, $1 \mathrm{ft}$. high ; bracts of the umbel 2-3, ovate, acuminate; umbel consisting mostly of sessile bulblets ; the few flowers long-pediceled, rose-colored; perianth about as long as the stamens, filaments dilated below ; capsule shorter than the perianth, 6-toothed, seeds 2 in each cell. May-June. On noist soil.

2. A. mutabile Michx. Wild Onion. Bulbs ovoid, solitary, or clustered, outer coat a network of slender fibers ; leaves very narrow, concave; scape erect, longer than the leaves, $1 \mathrm{ft}$. high; umbel erect, many-flowered, bulblets few, bracts 3 ; perianth white or rosecolored, the segments acute, as long as the stamens; carsule shorter than the perianth, not toothed, seeds 2 in each cell. March-June. In dry, sandy soil.

3. A. striatum Jacq. Striped Wild Onion. Bulbs clustered, outer coat membranaceous ; leaves linear, concave, striate on the back; scape 6-12 in. high; umbel 3-10-flowered, bracts 2, pedicels 1-2 in. long; perianth nearly white, longer than the stamens, the outer segments green-keeled on the back; capsule not toothed, seeds several in each cell. March-April. Low pine barrens.

\section{HYACINTHUS.}

Acaulescent herbs from coated bulbs; leares linear, fleshy; flowers in an erect spike, pediceled, bracted, perianth tubular below, lobed and spreading above; stamens short, included; style short, stigma capitate, ovary 3-celled, many-ovuled.

H. orientalis L. Hyacinth. Leaves lance-linear, thick and fleshy, smooth; scape erect, many-flowered; segments united about half their length, white, blue, or red; filaments very short; ovary rarely maturing seed. January-March. Common in cultivation.

\section{LILIUM.}

Perennial from scaly bulbs; stem erect, leafy, usually tall and slender; leaves sessile, scattered or whorled; flowers 
large, erect, or drooping, perianth corolla-like, deciduous, segments 6 , spreading or recurved above, sessile or clawed, each with a nectariferous groove near the base; stamens 6 , elongated, anthers linear, versatile; ovary 3 -celled, many-ovuled, style long and slender, stigma 3-lobed ; fruit a 3-celled, dehiscent, many-seeded capsule.

1. L. Catesbei Walt. Southern Red Lily. Bulbs small, scales narrow, leaf-bearing; stem slender, 1-2 ft. high; leaves scattered, linear, or linear-lanceolate, obscurely nerved, 1-2 in. long; flowers solitary, terminal, scarlet with yellow and purple markings, segments lanceolate, acute, spreading, wavy-margined, long-clawed, the margins of the claws involute; capsule oblong, nearly terete. July-August. Low pine barrens.

2. L. Carolinianum Michx. Carolina Lily. Bulbs globose, on short rootstocks, scales fleshy ; stem slender, $2-3 \mathrm{ft}$. high ; leaves scattered or sometimes whorled, oval, or oblanceolate, acute or obtuse at the apex, narrowed below, faintly 3-nerved ; flowers 1-3, nodding on long peduncles, perianth segments orange-red and purple-spotted, lanceolate, acute, the edges involute, strongly recurved; capsule obovoid. June--July. In dry woods.

3. L. tigrinum Andr. Tiger Lily. Bulb solitary, large, scales lanceolate, fleshy; stem erect, stout, often purple or black, smooth below, pubescent above, 2-5 ft. high; leaves very numerous, alternate, smooth, or slightly pubescent, 5-nerved, often with black or purplish bulblets in the axils; flowers numerous, orange-red with black or purple spots, nodding, segments lanceolate, pubescent, strongly recurved. May-August. Introduced from China and common in gardens.

\section{ERYTHRONIUM.}

Low herbs, from scaly corms; stem simple, bearing 2 unequal leaves below the middle; flowers solitary, white or yellow, nodding, bractless, perianth segments 6 , distinct, lanceolate, or oblong, spreading, with a nectariferous groove, deciduous; stamens 6, slender, shorter than the perianth; ovary sessile, 3-celled, many-ovuled, style slender, thickened above, 3-lobed; fruit a 3 -angled capsule.

E. Americanum Ker. Yellow Dog-tooth Violet. Corm deep in the ground, thus making the leaves often appear radical; leaves elliptical or oblanceolate, thick, acute at each end, entire, smooth, usually mottled with light and dark green, and purple; 
peduncle about as long as the leaves; flowers 1 in. long, yellow, sometimes spotted with purple, the 3 inner perianth segments 2toothed at the base; style club-shaped, capsule obovate, seeds ovoid, with a membranous appendage at the apex. February-March. In rich woods.

\section{VI, ORNITHOGALUM.}

Acaulescent herbs from coated bulbs; leaves linear, fleshy; scape erect; flowers in corymbs or racemes, bracted; perianth segments 6 , white, nerved, persistent; stamens 6 , hypogynous, slender, filaments flattened; ovary sessile, 3-celled, few-ovuled, fruit a roundish, 3-angled capsule, seeds black.

O. umbellatum L. Star of Bethlehem. Bulb ovoid, membranous-coated; leaves numerous, linear, fleshy, as long as the scape, mid-vein nearly white; scape slender, 6-12 in. high; flowers opening in sunshine, long-pediceled; bracts linear-lanceolate, about as long as the pedicels; perianth segments oblong-lanceolate, white with a green stripe on the back, twice the length of the stamens. April-June. Introduced from Europe; very common about old gardens.

\section{ALETRIS.}

Perennial from fibrous and bitter roots; stems erect and scape-like; basal leaves in a rosulate cluster, lanceolate; stem leaves small and bract-like; flowers in a terminal, bracted spike; perianth oblong or tubular, rough and viscid without, smooth within, 6-parted, the tube adherent to the ovary; stamens 6 , short, included, inserted at the top of the tube; ovary 3-celled, many-ovuled, style subulate, persistent, stigmas 3, fruit an ovoid, 3-celled, many-seeded capsule, seeds ovate, ribbed.

1. A. farinosa L. Colic-root. Basal leaves numerous, lanceolate or elliptical, acuminate at the apex, sessile, pale yellowish-green ; stem scape-like, furrowed or striate, 2-3 ft. high ; spike rigid, 4-12 in. long, flowers pediceled, bracted, perianth cylindrical, white, or the spreading lobes yellowish; style slender, 3-cleft, capsule ovoid, longer than the perianth. May-June. On damp pine barrens.

2. A. AUrea Walt. Yellow Colic-root. Basal leaves numerous, ovate-lanceolate, very acute, narrowed into a short petiole; stem nearly smooth, 2-3 ft. high ; raceme 1-2 ft. long, slender; flowers 
scattered, pedicels very short, perianth yellow, globose-ovate, with broad obtuse lobes; style short, obscurely 3-cleft, capsule ovate, about as long as the perianth. May-June. Low, sandy soil.

\section{YUCCA.}

Plants with woody and leafy stems, leaves numerous, rigid, spine-pointed, persistent; flowers in large terminal racemes or panicles, bracted, nodding; perianth campanulate or bellshaped, segments 6 , nearly alike, deciduous ; stamens 6 , filaments thickened above, often papillose, anthers small; ovary sessile, 3-celled, or becoming 6-celled, 3-angled, many-ovuled, fruit an oblong, 3-angled, many-seeded, dehiscent capsule, or fleshy and indehiscent.

1. Y. aloifolia L. Aloe-leaved Yucca. Stem erect, 3-6 in. in diameter, branched, rough with the transverse leaf-scars, 4-8 ft. high ; leaves rigid, linear-lanceolate, strongly spine-pointed, rough on the margin, the older leaves reflexed ; panicle short, smooth, densely flowered, 12-18 in. long; perianth white, sometimes tinged with purple ; capsule pulpy, 6-angled, indehiscent. May-June. On sandy soil, more common near the coast.

2. Y. fillamentosa L. Spanish Dagger. Stem stout, 4-12 in. high ; leaves linear or linear-lanceolate, slender-pointed, narrowed above the spreading and clasping base, spreading or recurved, smooth, with loose, thread-like filaments on the margins; panicle elongated, with bract-like leaves on the scape, widely branched, pubescent above, 3-6 ft. high ; perianth white, bell-shaped, 2 in. wide ; capsule oblong, anglês rounded, sides furrowed, at length 3 -valved and dehiscent. May-June. In sandy soil and often cultivated for ornament.

\section{CONVALLARIACEA. LILY-OF-THE-VALLEY FAMILY.}

Perennial herbs, stems leafy or scapose, often from a thickened rootstock, never from a bulb or corm; flowers solitary or variously clustered; leaves broad and often with netted veins, or filiform, alternate or whorled; perianth 4-6-parted, segments distinct or partly united; stamens $4-6$, hypogynous or inserted on the perianth; ovary free, 2-3-celled, ovules few or many, style long or short, stigmas mostly 3-lobed; fruit a berry. 


\section{ASPARAGUS.}

Stem from fleshy fibrous roots, erect, branched, branches slender, with filiform branchlets in the axils of scales which take the place of leaves; flowers small, solitary or racemed, perianth 6-parted, segments distinct or slightly united; stamens 6 , perigynous, filaments filiform; ovary 3-celled, 6 -ovuled, style short, slender, stigmas 3 , recurved; fruit a globose berry.

A. officinalis L. Asparagus. Stem succulent and simple with fleshy scales when young, becoming taller, more woody and widely branched when old ; leaves short, filiform ; flowers axillary, solitary, or 2 or 3 together on slender, jointed, drooping pedicels, greenish, segments linear; berry red, few-seeded. May-August. Introduced from Europe, common in cultivation, and often escaped.

\section{POLYGONATUM.}

Rootstock creeping, jointed, scarred; stems simple, erect, scaly below, leafy above; leaves alternate, oval or oblong; flowers on axillary, 1-4-flowered, drooping, jointed peduncles, perianth tubular, 6-cleft; stamens 6 , included, inserted about the middle of the tube; anthers sagittate; ovary 3-celled, many-ovuled, style slender, stigmas capitate or 3-lobed ; fruit a few-seeded berry.

1. P. biflorum (Walt.) Ell. Hairy Solomon's Seal. Stem simple, erect, arched, nearly naked below, 1-2 ft. high; leaves 2-ranked, sessile or clasping, 3-7-nerved, smooth above, pale and pubescent beneath ; peduncles short, 1-4- often 2-flowered, perianth greenish, $\frac{1}{2}$ in. long ; filaments filiform, roughened; berry dark blue. April-May. Shady banks.

2. P. сомmutatum (R. \& S.) Dietr. Sмоoth Solomon's Seal. Stem simple, stout, curving above, $3-8 \mathrm{ft}$. high ; leaves lanceolate to ovate, many-nerved, partly clasping, smooth on both sides; peduncles nearly half as long as the leaves, 2-6-flowered; perianth greenish yellow, $\frac{3}{4}$ in. long ; filaments smooth; berry blue, $\frac{1}{2}$ in. in diameter. May-June. In rocky woods and along streams.

\section{MEDEOLA.}

Rootstock horizontal, fleshy; stem simple, erect; leaves in two whorls; flowers perfect, in a sessile umbel; perianth 
greenish-yellow, segments 6, distinct, deciduous ; stamens 6, hypogynous, filaments slender, smooth; ovary 3-celled, manyovuled, styles 3 , slender, recurved; fruit a globose berry.

M. Virginiana L. Indian Cucumber-root. Stem clothed with loose deciduous wool, erect, 1-2 ft. high; the lower whorl of 6-8 sessile, oblong-lanceolate, acuminate, 3-5-nerved leaves, the upper whorl of 3-4, ovate, sessile or short-petioled leaves ; flowers 2-8, nodding, becoming ascending in fruit; perianth segments $\frac{1}{4}-\frac{1}{3}$ in. long, obtuse; styles red, berry dark purple. May-June. Shady banks and moist woods.

\section{TRILLIUM.}

Perennial, from tuberous rootstocks; stem simple, erect; leaves 3, whorled at the summit of the stem; flower terminal, solitary, peduncled or sessile, perfect; perianth of 6 leaves, the 3 outer green, persistent, the 3 inner colored and petallike, deciduous or persistent; stamens 6, hypogynous, filaments short; ovary sessile, 6-ribbed, 3-celled, many-ovuled, styles 3, slender, recurved, persistent; fruit a subglobose, many-seeded purple berry.

1. T. sessile L. Sessile-flowered Wake-robin. Rootstock erect or ascending, corm-like; stem slender, 1-8 in. high; leaves broadly oval, obtuse or acute at the apex, rounded and sessile at the base, 3-5-nerved, smooth, bright green, not mottled ; flowers sessile, sepals lanceolate, $\frac{2}{3}-1$ in. long, petals purple, elliptical, about the length of the sepals; stamens half the length of the petals; styles elongated, straight. April-May. In rich woods.

2. T. Underwoodi Small. Underwood's Wake-robin. Rootstock horizontal, stem stout, 4-12 in. high ; leaves ovate-lanceolate to broadly ovate, acute or short acuminate at the apex, rounded and sessile at the base, wavy on the margins, 3-5-nerved, glabrous, prominently mottled with different shades of green ; flowers sessile, sepals lanceolate, $1 \frac{1}{2}-2$ in. long, often purplish green, petals purple, lanceolate to oblanceolate, $2-3$ in. long; stamens $\frac{1}{4}-\frac{1}{3}$ the length of the petals, style very short, stigmas recurved; fruit an ovoid berry. April-May. In rich woods.

3. T. GRANDIFlorum (Michx.) Salisb. LARge-flowered Wake-robin. Rootstock horizontal, stem slender, 12-18 in. high; leaves rhombic-ovate, acuminate at the apex, rounded and sessile or slightly peduncled at the base, smooth and glaucous, 5-7-nerved, 
bright green; peduncle longer than the erect or slightly declined flower, sepals lanceolate-acute, $1-1 \frac{1}{2}$ in. long, petals white fading to pink, longer than the sepals; stamens less than half the length of the petals; style short, stigmas recurved, fruit a black globose berry. April-May. In rich woods.

\section{SMILACE $\mathbb{E}$. SMILAX FAMILY.}

Mostly woody climbing vines with prickly stems; leaves alternate, prominently nerved, netted-veined, petioled, stipules replaced by persistent tendrils; flowers diœcious, small, greenish, in axillary umbels ; perianth segments 6 ; stamens 6 , distinct; ovary 3-celled, 3-6-ovuled, stigmas 1-3, sessile or nearly so; fruit a 1-6-seeded globose berry.

\section{SMILAX.}

Rootstock often large and tuberous; stems usually woody, climbing by tendrils; leaves entire or lobed; petioles sheathing; flowers regular, perianth bell-shaped, the 6 segments equal and deciduous; stamens 6 , inserted on the base of the perianth; ovary free, 1-3-celled, 3-6-ovuled, stigmas 1-3; berry 1-6-seeded.

1. S. herbacea L. Carrion-flower. Stem herbaceous, erect, simple or branched, not prickly, 1-3 ft. high; leaves few, ovate, acute and mucronate at the apex, somewhat cordate at the base, 5-7-nerved, thin, smooth above, pubeseent below, the upper sometimes whorled and the lower bract-like; petioles short; peduncles as long as the leaves, growing from below the petioles; umbel many-flowered, flowers carrion-scented; berry blue-black, 2-4-seeded. April-June. Dry, fertile soil.

2. S. Glauca Walt. Glaucous Greenbrier. Stem terete, slender, with scattered prickles, branches angled, and usually without prickles; leaves ovate or subcordate, pointed at the apex, mostly 5-nerved, smooth, white-glaucous beneath, margins entire; peduncles flattened, 2-3 times as long as the petioles, few-flowered; berry black, 3 -seeded. May-June. Margins of swamps.

3. S. Bon-nox L. Bristly Greenbrier. Stem stout, terete or slightly angled, scurfy when young, armed with numerous stout 
prickles; branches 4-angled, usually unarmed; leaves deltoid-ovate or often hastate, 5-7-ribbed, smooth on both sides and often discolored, margins usually fringed with fine prickles; peduncles twice as long as the petioles, flattened ; umbels many-flowered, pedicels short ; berries 8-20 in a cluster, black, 1-seeded. April-June. In swamps and thickets.

4. S. Laurifolia L. Laurel-leaved Greenbrier. Stem terete, stout, thickly beset with stout, straight prickles; branches 1-angled, mostly unarmed; leaves thick, evergreen, elliptical to narrowly ovate, obtuse at both ends, smooth, 3-nerved ; peduncles shorter than the petioles, angled, stout; pedicels shorter than the peduncles ; berries black, 1-seeded, ripening the second season. March-August. Margins of streams and swamps.

5. S. Walteri Pursh. Walter's Greenbrier. Stem low, with few prickles, 2-5 ft. long, branches slightly 4-angled, unarmed; leaves oblong-lanceolate to oval, obtuse or acute at the apex, rounded or cordate at the base, 5-ribbed, smooth; peduncles flattened, about as long as the petioles and pedicels; berry bright red, ripening the first year. March-April. Wet pine barrens.

\section{HEMODORACE E. BLOODWORT FAMILY.}

Perennial herbs from short rootstocks; stem erect; leaves linear, equitant; flowers in a terminal cyme or panicle, regular or nearly so, the persistent perianth 6 -parted, adnate to the ovary; stamens 3 ; ovary 1 -3-celled, few-ovuled, style slender, stigma entire or lobed; fruit a 3-valved capsule.

\section{GYROTHECA.}

Stem stout, leafy; juice orange-colored; leaves narrowly linear, equitant; flowers in a dense, terminal, woolly cyme; perianth 6-parted, woolly without, the three inner segments longer, tube adnate to the ovary; stamens opposite the inner segments, longer than the perianth; style filiform, declined, deciduous, capsule globose, 3-angled, many-seeded.

G. CApitata (Walt.) Morong. ReD-Root. Rootstock rather stout, with coarse, red, fibrous roots; stem mostly simple, smooth below, woolly above; leaves linear, crowded and equitant below, 
scattered and clasping above ; flowers 2-ranked in a compound woolly cyme, pedicels bracted; perianth woolly without, yellow and smooth within; capsule as long as the pedicels, the valves separating from the placentæ, seeds black. June-September. Swamps and wet places.

\section{AMARYLLIDACEAE. AMARYLLIS FAMILY.}

Perennial herbs with a bulbous or tuberous root, mostly succulent; leaves narrow; flowers perfect, often showy, perianth 6-parted, the segments united below to form a tube which is partly or wholly adherent to the ovary; stamens 6 , opposite the perianth lobes, anthers versatile or introrse; ovary 3-celled, few- or many-ovuled, style single, filiform, entire or lobed; fruit a capsule or rarely fleshy, valvular or indehiscent.

Plants from bulbs.

Scape 1-flowered

I. Amaryllis.

Scape several-flowered.

Flowers with a membranous crown .

II. Hymenocallis.

Flowers crownless

III. Crinum.

Plants from rootstocks.

Flowers in spikes . . . . . IV. Agave.

Flowers in umbels . . . . . . V. Hypoxis.

Flowers in panicles . . • . . VI. Lophiola.

\section{AMARYLLIS.}

Acaulescent, from a coated bulb; leaves linear, fleshy; scape erect, 1-few-flowered; flowers large, erect, or declined, subtended by a 1-2-leaved spathe; perianth 6-parted, naked in the throat, tube short, segments petal-like, spreading; stamens free, anthers versatile; ovary 3-celled, many-ovuled, style elongated, declined, stigma 3-cleft; fruit a many-seeded, 3 -valved capsule, seeds black, compressed, or angled.

A. Atamasco L. Atamasco Lily. Bulbs about 1 in. in diameter; leaves narrow, concave above, glabrous, usually longer than the seape; scape 6-12 in. high, 1-flowered; spathe 1-leaved, 2 cleft ; flowers 2-3 
in. long, white tinged with pink or purple, bell-shaped, short-peduncled; stamens longer than the tube, shorter than the style, capsule depressedglobose, seeds angled. April. In rich, damp soil, often cultivated.

\section{HYMENOCALLIS.}

Acaulescent from a large coated bulb; leaves strap-shaped, long; scape erect, compressed, 2-edged, bearing a cluster of leafy-bracted flowers at the apex; perianth corolla-like, 6-parted, tube long and slender, perianth lobes narrow, spreading, or recurved; stamens 6, the filaments broadened and united below to form a crown with toothed and spreading edge, upper part of the stamens exserted, anthers versatile; style long and slender, stigma entire; fruit a membranaceous, 3-celled capsule, seeds often bulb-like.

H. occidentalis (Le C.) Kunth. Sivamp Lily. Bulb 2-3 in. in diameter; leaves linear or strap-shaped, obtuse, thick, glaucous, concave above, 1-2 ft. long; scape stout, 2-edged, as long as the leaves, smooth, about 6-flowered; bracts several, linear-lanceolate; perianth white, the tube slender, $3-5$ in. long, not dilated at the apex, perianth lobes linear, spreading or recurved, nearly as long as the tube; crown fumnel form, toothed between the filaments, style much exserted, capsule few-seeded. June-August. In wet places.

\section{CRINUM.}

Characters the same as those of Hymenocallis, excepting that the flowers are crownless.

C. Americanum L. Crinum. Bulb 2-4 in. in diameter; leaves strap-shaped, obtuse, concave above, slightly denticulate; scape fewflowered, compressed, edges rounded, smooth, 18-24 in. high ; bracts lanceolate; flowers 6-8 in. long, white, fragrant, tube green, persistent, perianth segments lanceolate, spreading or recurved, shorter than the tube; stamens exserted, filaments purple; ovary 3-celled, 3-6 ovuled, stvle slender, purple, stigma truncate, capsule indehiscent, 1-6-seeded, seeds large, corm-like. May-September. River banks and swamps.

\section{AGAVE.}

Rootstocks short and thick, tuberous; leaves mostly basal, fleshy, with a toothed or spiny margin; scape tall, with leaf- 
like bracts; flowers in simple or panicled spikes, perfect, bracted; perianth tubular-funnel form, 6-lobed, persistent; stamens 6 , inserted at the base of the perianth, exserted, anthers versatile; ovary 3-celled, 3-lobed, many-ovuled, style filiform, exserted, stigma 3-lobed, fruit a 3-celled, 3-valved, many-seeded, dehiscent capsule, seeds compressed.

A. Virginica L. False Aloe. Whole plant smooth and glaucous; leaves lanceolate, thick, long, acuminate and spine-pointed, sparingly denticulate, surface often mottled; scape erect, simple, very white-glaucous, 3-5 ft. high; spike simple, flowers greenishyellow, perianth tubular, strongly nerved, about $1 \mathrm{in}$. long, lobes short, slightly spreading; filaments and style spotted, capsule coriaceous, 3-lobed at the apex, seeds shiny. June-August. In dry soil.

A. Americana L., the century plant, is often cultivated for ornament in the southern section.

\section{HYPOXIS.}

Low herbs; rootstock short, tuberous; leaves grass-like; scape naked, bearing a few yellow flowers in a bracted umbel, perianth 6-parted, spreading, persistent, the outer segments green on the outside, tube short; stamens 6 , inserted at the top of the tube, short, unequal; ovary 3-celled, many-ovuled, style short and thick, stigmas 3 , fruit a top-shaped, manyseeded capsule, the upper portion with the withered perianth falling off at maturity, seeds globose, black, beaked by their persistent stalks.

H. hirsuta (L.) Coville. Star-Grass. Leaves linear, grass-like, channeled above, hirsute or woolly, becoming longer than the scape; scapes $1-4$, slender, somewhat flattened, usually smooth below and hairy above, 3-6 in. high ; bracts subulate, shorter than the unequal, hairy pedicels; perianth segments oblong, obtuse, yellow within, green and hairy without, stamens unequal, longer than the style; capsule several-seeded, seeds angled. March-July. Common on low ground.

\section{LOPHIOLA.}

Perennial herbs from slender rootstocks; stem leafy ; leaves linear and rigid; inflorescence in a terminal, woolly, cymose panicle; flowers small, yellow, woolly without, perianth 6- 
lobed, the tube adherent to the lower part of the ovary, lobes spreading; stamens 6 , inserted on the lower part of the perianth lobes, filaments slender, short; ovary 3-celled, manyovuled, style slender, erect, persistent, shorter than the stamens; fruit a 3-ribbed, 3-furrowed capsule; seeds oblong, ribbed.

L. Americana (Pursh) Coville. Lophiola. Stem erect, rigid, smooth below, branched and woolly above ; basal leaves linear, swordshaped, equitant, upper leaves scattered, smaller; panicle very whitewoolly, becoming broad in fruit; perianth segments linear-oblong, with a tuft of wool at the base within; capsule shorter than the perianth, ovoid. June-August. Wet pine barrens.

\section{IRIDACEÆ. IRIS FAMILY.}

Perennial herbs from bulbs or rootstocks; leaves 2-ranked, equitant; flowers perfect, regular or irregular, each subtended by two bracts; perianth 6 -parted, the tube adherent to the ovary, the segments in 2 series of 3 each, equal, or the inner ones smaller; stamens 3 , distinct or united, opposite the outer segments ; ovary forming a 3-celled, 3-angled, 3-valved, manyseeded, dehiscent capsule.

\section{IRIS.}

Rootstock thick, creeping, branching, horizontal, sometimes tuberous; stems erect, simple or branched; leaves linear or sword-shaped; flowers showy, the outer perianth segments spreading or recurved, often bearded within, the inner segments usually smaller and erect; stamens inserted in the base of the outer segments ; the style deeply 3-parted, the divisions broad and petal-like, covering the stamens; fruit an oblong or oval, 3 or 6 -angled, many-seeded capsule.

1. I. versicolor L. Large Blue Flag. Rootstock thick, horizontal ; stem terete, smooth, simple or branched, leafy, 2-3 ft. high ; leaves linear-sword-shaped, finely-nerved, glaucous, the lower $1 \frac{1}{2}-2 \mathrm{ft}$. long, the upper shorter; bracts longer than the pedicels; flowers terminal, single or few together, blue variegated with white, yellow, and purple, perianth segments not bearded, the inner ones smaller; 
the 3-angled ovary longer than the inflated perianth tube, capsule oblong, slightly lobed, seeds in 2 rows in each cell. April-May. In wet places.

2. I. hexagona Walt. Southern Blue Frag. Rootstock thick; stem terete, erect, usually simple, 2-3 ft. high; leaves linear, sword-shaped, as long as the stem, green; flowers axillary and terminal, deep blue, variegated with white, yellow, and purple, outer segments not bearded, often 4 in. long, inner segments smaller; perianth tube longer than the ovary; stigmas much longer than the stamens, cut-toothed at the apex, capsule oblong-cylindrical, 6-angled. April--May. In wet ground.

3. I. Germanica L. Fleur-De-Lis. Rootstock thick, matted; stem stout, branched, leafy, 2-3 ft. high; leaves strap-shaped, acute, erect, shorter than the stem, bracts scarious; flowers sessile, large and showy, blue, variegated with white and yellow, sometimes nearly all white, outer segments large, recurved, bearded, the inner narrower, erect, or arched inward. April-May. Introduced from Europe ; conmon in gardens and naturalized in many places.

4. I. Fulva Ker. Yellow FlaG. Rootstock fleshy; stem simple or branched, striate, 1-angled below, bearing 2-3 leaves, 2-3 ft. high; leaves linear, sword-shaped, glaucous, shorter than the stem, bracts small; pedicels short, flowers axillary and terminal, dull yellow or reddish-brown, variegated with blue and green, perianth segments not bearded; style branches but little exceeding the stamens, ovary about as long as the inflated perianth tube, capsule ovate, 6-angled. April-May. Swamps and wet places.

\section{SISYRINCHIUM.}

Perennial, tufted herbs; stems erect, simple, or branched, flattened, 2-edged or winged; leaves linear and grass-like; flowers small, blue, in terminal, umbellate, 2-bracted clusters, perianth corolla-like, tube short or none, segments 6 , equal, strongly aristate; stamens 3 , monadelphous; ovary 3 -celled, many-ovuled, style short, the branches long, filiform, and involute, alternate with the stamens; fruit a 3 -valved capsule, seeds smooth or pitted.

1. S. Graminoides Bickn. Blue-eyed Grass. Stem slender, broadly wing-margined, usually 2-branched above, 10-20 in. high ; leaves very slender and grass-like, shorter than the stem, the edges roughened; bracts about 1 in. long, the outer one sometimes the longer; umbels 2-4-flowered, pedicels slender, longer than the bracts, 
flowers bright blue, segments cuneate, slightly pubescent without; capsule globose, seeds black, pitted. April-June. Grassy meadows and dry soil.

2. S. Atlanticum Bickn. Eastern Blue-eyed Grass. Tufted, stems slender, sharply 2-edged, weak and often decumbent, finally few-branched, 6-18 in. high; leaves pale, glaucous, much shorter than the stem; bracts nearly equal, often somewhat scarious and purple-tinged; flowers bright blue, perianth minutely pubescent without, pedicels erect, about as long as the bracts; capsule ovoid, seeds ovoid, dull black, smooth or minutely pitted. April-June. On moist, sandy soil.

\section{ORCHIDACEÆ. ORCHIS FAMILY.}

Perennial herbs, roots bulbous, tuberous, corm-like, or fibrous; stems simple, leafy, or scapose; leaves simple, mostly alternate, sheathing, entire, smooth, or rarely pubescent, those on the stem often small and bract-like; flowers solitary, spiked or racemed, usually showy, perfect, very irregular; perianth 6-parted, segments united below and coherent with the ovary, the 3 outer divisions sepal-like and similar ; two of the inmer segments similar, the third. which is structurally the posterior segment, though often becoming anterior by the twisting of the ovary, very variable in form, sometimes forming a large pouch, often dilated and fringed, and usually forming a knob, or even a long and slender spur near the base; stamens 3 , rarely 2 , united with the style to form an irregular column, only one or two of them antherbearing; anthers 2-celled, pollen grains cohering in 2-8 waxy or powdery masses (pollinia) attached to a viscid gland at the base ; ovary usually elongated, 1-celled, with 3-parietal placentæ ; fruit a 3-valved, many-seeded, dehiscent capsule, seeds minute, covered with a loose, membranous coat.

[Most of the species flower late in the season, and their classification is based principally on the number and character of the anthers and pollinia.] 


\section{SUBCLASS 2. DICOTYLEDONS.}

Stems with distinct bark, wood, and pith ; fibrovascular bundles in rings; leaves netted-veined; parts of the flower mostly in 5's, rarely in 3 's or 6's ; cotyledons 2 .

\section{SAURURACEA. LIZARD-TAIL FAMILY.}

Perennial herbs; stems jointed; leaves simple, alternate, entire, with sheathing stipules; flowers perfect, in bracted, terminal spikes or racemes; perianth none, stamens 4-8, hypogynous; ovaries $3-5$, more or less united, ovules few; styles 3-5; fruit a few-seeded capsule, or somewhat fleshy.

\section{SAURURUS.}

Characters of the family.

S. Cenrnuus L. Lizard-tail. Stem erect, from a slender rootstock, forked above, pubescent when young, becoming smooth, 2-4 ft. high ; leaves cordate to ovate, strongly 5-9-ribbed, acute or acuminate at the apex, on stout petioles; spikes slender, drooping at the apex, closely flowered, peduncled; flowers white, fragrant, bracted ; stamens spreading, filaments club-shaped ; fruit somewhat fleshy, of 3-4 carpels, each carpel 1-2-seeded. May-August. In marshes and muddy places.

\section{JUGLANDACEAE. WALNUT FAMILY.}

Trees with alternate, odd-pinnate leaves without stipules; flowers monœcious, the staminate in long and drooping aments, stamens few or many, calyx 2-6-parted; the fertile solitary or in small clusters, calyx $3-5$-lobed, minute petals sometimes present, ovary 1-celled or incompletely 2-4-celled; fruit a drupe with a dry exocarp enclosing a bony endocarp or nut. 


\section{JUGLANS.}

Staminate aments cylindrical, solitary, borne on wood of the previous year, stamens numerous, filaments short, calyx 4-6-parted; pistillate flowers single or a few together on a short peduncle at the base of the growth of the season; calyx 4-parted, petals 4, minute, adnate to the ovary ; styles 2, short, plumose, fruit large, globose or oval, exocarp fibrous-fleshy, becoming dry, indehiscent, endocarp bony, very rough.

1. J. nigra L. Black Walnut. Leaflets 13-21, ovate-lanceolate, serrate, acuminate, somewhat cordate or oblique at the base, nearly smooth above, pubescent beneath, petioles minutely downy; fruit usually single, globose, about 2 in. in diameter. April-May. On rich soil, rare near the coast. One of the most valuable of our native trees, the wood being very durable and highly prized for cabinet work.

2. J. cinerea L. Butternut. Leaflets 15-19, ovate-lanceolate, acuminate at the apex, rounded or slightly inequilateral at the base, serrate, downy beneath ; petioles, branchlets, and fruit viscidpubescent ; fruit often in small clusters, oblong. April-May. More common northward. Wood less valuable and nut less oily than Black Walnut. The English Walnut (J. regia) is occasionally seen in cultivation. It has 7-11 leaflets and a nearly smooth endocarp.

\section{HICORIA.}

Leaflets serrate; staminate aments usually in 3 's on a common peduncle, or sometimes sessile at the base of the growth of the season; calyx 2-3-parted, stamens 3-10, filaments short; pistillate flowers $2-5$ in terminal clusters, calyx 4-parted, petals none, styles 2 or 4 , fimbriate; fruit subglobose, exocarp separating more or less completely into 4 valves, endocarp smooth or angled.

1. H. Pecan (Marsh) Britt. Pecan. A large tree with rough gray bark, young twigs and leaves pubescent, nearly glabrous when mature ; leaflets 11-15, oblong-lanceolate, acuminate, serrate, falcate ; staminate aments nearly sessile, 5-6 in. long ; exocarp thin, nut oval or oblong, thin-shelled. March-April. River-bottoms. Rarely native east of the Mississippi River, but widely planted for its fruit. 
2. H. ovata (Mill) Britt. Scaly-bark Hickory. A large tree with bark scaling off in long plates, young twigs and leaves downy, becoming smooth with age; leaflets 5 , the lower ones oblong-lanceolate, the upper one longer and obovate, acuminate at the apex, narrowed to the sessile base; inner bud scales becoming large and conspicuous ; staminate aments in 3's ; fruit globose, exocarp thick, splitting into 4 sections, nut white, compressed, 4-angled, pointed, thin-shelled. March-April. On rich soil. More common in the northern section. Wood strong and elastic, but not durable when exposed.

3. H. Glabra (Mill) Britt. Pig-nut Hickory. A large tree with close, rough bark; young twigs and leaves nearly glabrous; leaflets 5-7, usually 7, ovate-lanceolate, acuminate, sessile, 3-6 in. long; staminate aments in 3 's ; fruit oval to pear-shaped, exocarp thin, splitting to about the middle ; nut brown, angled, thick-shelled, kernel at first sweet, the after-taste bitter. March-April. Common on rich soil. Wood very strong and elastic. Used largely for handles of tools. Six other species of hickory are more or less common throughout the South.

\section{MYRICACEA. BAY-BERRY FAMILY.}

Shrubs with alternate, simple, resinous-dotted leaves; monœecious or diøcious; flowers in short, bracted aments, perianth none; staminate flowers $2-10$, stamens inserted on the receptacle; pistillate flowers surrounded by 2-6 scales, ovary 1-celled, style short, stigmas 2.

\section{MYRICA.}

Shrubs or small trees with the branches clustered at the end of the growth of the previous season; leaves shortpetioled, entire, lobed or dentate, the margin usually revolute, without stipules; perianth none; staminate flowers in oblong or cylindrical aments, stamens 2-10, with the filaments united below; pistillate flowers surrounded by a cup of 2-6 scales, ovary solitary, becoming a 1-celled, globose drupe or nut, often covered with waxy grains. Whole plant usually fragrant.

M. Cerifera L. IVAXberry. A spreading shrub or small tree; young branches pubescent; leaves lanceolate or oblong-lanceolate, 
entire or sometimes serrate near the mostly obtuse apex, smooth or pubescent on the veins beneath, tapering into a short petiole; staminate aments numerous, stamens 4 ; pistillate aments small, bracts slightly 3 -lobed, scales of the ovary 4 , ciliate ; stigmas 2 , fruit very abundant, incrusted with white wax, $\frac{1}{8}-\frac{1}{6}$ in. in diameter, sometimes persistent 2 or 3 years. March-April. Common on wet soils, especially near the coast.

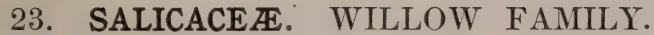

Trees or shrubs with simple, alternate, deciduous, stipulate leaves, buds scaly, covered with a resinous varnish; flowers diceious, in aments expanding before or with the leaves; staminate aments usually drooping, flowers consisting of one or more stamens inserted on a receptacle in the axil of a simple bract; pistillate aments drooping, erect, or spreading; ovary 1-celled, with 2-4 placentæ and usually numerous ovules, style short, stigmas 2, often 2-lobed; seeds small, covered with fine silky hairs.

\section{POPULUS.}

Trees with prominent, scaly buds, twigs more or less angled, leaves usually long-petioled, bracts of the aments irregularly lobed at the apex; stamens few or many, filaments distinct; pistillate aments often long, ovary sessile, style short, stigmas 2-4, elongated, capsule 2-4-valved.

1. P. Deltordes Marsh. Cottonwood. Branches acutely angled; leaves glabrous, large, deltoid, acute or acuminate at the apex, truncate at the base, obtusely serrate, petioles flattened laterally; pistillate aments $6-10$ in. long at maturity, capsule usually shorter than the pedicel. March-May. On damp soil.

2. P. heterophylla L. Swamp Poplar. Branches only slightly angled; leaves ovate, mostly obtuse at the apex, rounded or sub-cordate at the base, serrate with obtuse teeth, densely tomentose when young, but becoming smooth with age; petioles terete; pistillate aments smooth, erect or spreading, loosely flowered; capsule ovoid, usually shorter than the pedicel. March-April. Common in river swamps. A large tree with soft, light wood, which is often used in making cheap furniture. 


\section{SALIX.}

Shrubs or trees, branches usually very slender, buds with single scales; leaves usually long and narrow ; stipules sometimes leaf-like or often small and soon deciduous; bracts of the aments entire ; staminate aments erect or drooping, staminate flowers with $2-10$, mostly 2 , distinct or united stamens ; pistillate aments usually erect, flowers with a small gland on the inner side of the bract, stigmas short, 2-lobed; capsule 2 -valved.

1. S. Nigra Marsh. Black Willow. Leaves elliptical or narrowly lanceolate, acute at each end, serrate, short-petioled, downy when young and becoming smooth with age, $2-3$ in. long ; stipules persistent or deciduous; staminate aments 1-2 in. long; the pistillate 2-4 in. long; stamens $3-7$, distinct, filaments pubescent below; capsule twice the length of the pedicel, ovate, acuminate, pointed by the prominent style. March-April. A small tree with very brittle branches. Along streams and borders of marshes.

2. S. Babylonica L. Weeping Willow. Leaves narrowly lanceolate, acuminate, serrate, slightly downy when young and becoming smooth with age, green above, pale beneath, often 5-7 in. long, petioles short, glandular; aments on short lateral branches; stamens 2, style almost none, capsule sessile, glabrous. MarchApril. Introduced and cultivated for ornament, becoming a large tree.

\section{BETULACEA. BIRCH FAMILY.}

Trees or shrubs, with alternate, simple, petioled leaves with usually deciduous stipules; monœcious flowers in cylindrical or subglobose aments, staminate aments drooping; flowers 1-3 in the axil of each bract, calyx none, or membranous and 2-4-parted; stamens $2-10$, distinct; pistillate aments drooping, spreading, or erect and spike-like; flowers with or without a calyx, ovary solitary, 1-2-celled, ovules 1-2 in each cell; fruit a 1-celled nut or samara.

\section{CARPINUS.}

Trees with thin, straight-veined leaves, which are folded in the bud; flowers expanding before the leaves; staminate 
flowers in slender, drooping aments sessile at the end of the growth of the previous season; stamens $3-12$, subtended by a bract, filaments forked, anthers hairy; pistillate aments spike-like, each pair of flowers subtended by a deciduous bract, and each flower by a persistent bractlet which becomes large and leaf-like in fruit ; ovary 2-celled, 2-ovuled ; stigmas 2 , filiform; fruit a small angular nut.

C. Caroliniana Walt. Hornbeam. A small tree with smooth and close gray bark; twigs slender; leaves ovate-oblong, acute or acuminate, sharply and doubly serrate, the straight veins terminating in the larger serrations; downy when young and soon becoming smooth ; staminate aments $1-1 \frac{1}{2}$ in. long; pistillate aments longpeduncled, 8-12-flowered; bractlets becoming nearly 1 in. long, cuttoothed, the middle tooth much longer than the others. FebruaryMarch. In rich, moist woods. Often known as "blue beech" and " iron wood."

\section{OSTRYA.}

Small trees, with dark bark and very hard wood; leaves open and concave in the bud and somewhat plaited on the veins; staminate flowers on slender, drooping aments sessile at the end of the growth of the previous season; stamens 3-12, subtended by a bract, filaments forked, anthers hairy ; pistillate flowers surrounded by a tubular bractlet which becomes large and bladder-like at maturity; fruit a small, pointed, smooth nut; mature ament hop-like.

O. Virginiana (Mill) Willd. A small tree with brownish, furrowed bark; leaves ovate, acute, doubly serrate, often inequilateral at the base, short-petioled; staminate and fertile aments $2-3$ in. long. February-March. Mature fruit June-July. In rich woods. Often known as "iron wood" and "lever wood."

\section{CORYLUS.}

Shrubs with prominently veined, cut-toothed leaves which are folded lengthwise in the bud, and with the flowers expanding before the leaves; staminate flowers in slender, drooping aments; stamens 8, anthers 1-celled; fertile flowers several in a cluster or in very short aments at the ends of the twigs of the season; ovary incompletely 2-celled, style short, stig- 
mas 2 , bractlets 2 , becoming enlarged and enclosing the single bony nut at maturity.

C. Americana Walt. Hazel-nut. A shrub 4-7 ft. high, young twigs and petioles covered with brownish, viscid hairs; leaves round-cordate, acute or acuminate, irregularly toothed, nearly smooth above, pubescent below ; involucre longer than the nut and enclosing it, glandular-hairy ; nut subglobose, pointed, edible. FebruaryMarch. On rich soil, borders of meadows and fields.

\section{BETULA.}

Trees with slender, aromatic twigs and thin, usually straightveined leaves ; staminate aments drooping, flowers usually 3 in the axil of each bract, stamens 4, short, anthers 1-celled; pistillate aments erect, flowers 2 or 3 in the axil of each bract; ovary sessile, 2 -celled, styles 2 ; bracts 3 -lobed; perianth none; nut broadly winged.

1. B. Nigra L. Black Birch. A medium-sized tree with reddish-brown bark ; leaves rhombic-ovate, acute at the apex, acute or obtuse at the base, sharply and doubly serrate, white-downy below, becoming smoother with age, petioles short; staminate aments 2-3 in. long ; pistillate aments 1-1 $\frac{1}{2}$ in. long, peduncles short, bracts nearly equally 3 -cleft, woolly. March-April. River banks.

2. B. Lenta L. Cherry Birch. Leaves ovate or oblong-ovate, acute, cordate, finely and doubly serrate, silky when young; petioles about $\frac{1}{2}$ in. long; staminate aments clustered, $3-4$ in. long; pistillate aments sessile, about $1 \mathrm{in}$. long, cylindrical bracts spreading, acute, smooth. March-April. River banks, especially in the northern districts. A large tree with aromatic twigs. The oil contained in the bark and twigs is distilled and used as a substitute for wintergreen.

\section{ALNUS.}

Shrubs or small trees; leaves petioled, serrate; flower buds stalked, appearing the previous season; staminate aments racemed, drooping flowers $3-6$ in the axil of each bract, subtended by 1-2 bractlets, perianth 4-parted, stamens 4, filaments short; pistillate aments erect, flowers $2-3$ in the axil of each bract, perianth replaced by 2-4 minute bractlets which are adherent to the bract; ovary 2 -celled, styles 2 , fruit a 
winged or angled nut; bracts of the pistillate flowers somewhat fleshy, persistent, becoming woody in fruit.

A. Rugosa (Du Roi) Koch. Sмоoth Alder. A shrub or small tree with smooth bark; leaves obovate, rounded or obtuse at the apex, acute at the base, sharply and minutely serrate, glabrous above, pubescent beneath, petioled, stipules oval, deciduous; staminate aments 2-4 in. long; fruiting aments ovoid, short-peduncled, fruit ovate, wingless. January-March. Banks of streams and borders of marshes. Leaves often persistent during the winter.

\section{FAGACEAE. BEECH FAMILY.}

Trees or shrubs ; leaves alternate, simple, pinnately veined; stipules deciduous; flowers monœcious, the staminate capitate, or in drooping, spreading, or erect aments, calyx minute, petals none, stamens $4-20$; pistillate flowers solitary or in small clusters, each flower subtended by more or less united bracts which at maturity form a cup or burr, calyx minutely toothed, petals none; ovary $2-7$ celled, but becoming 1 -celled; fruit a 1 -seeded nut.

\section{FAGUS.}

Trees with smooth, close, ash-gray bark, and slender, often horizontal branches; staminate flowers in long, slenderpeduncled, globose clusters, calyx bell-shaped, 4-6-cleft, stamens 8-12, anthers 2-celled; pistillate flowers solitary or more often in pairs, peduncled, surrounded by a 4-lobed involucre and numerous linear bracts; ovaries 3-celled with 2 ovules in each cell, but usually only one ovule matures in each ovary; styles 3, filiform, fruit a thin-shelled, 3-angled nut.

F. Americana Sweet. Beech. Large trees, leaves oblong-ovate, acuminate at the apex, serrate, straight-veined, very white-silky when young, nearly glabrous with age, involucre densely covered with short recurved spines; unts thin-shelled, edible. March-April. Common on damp soil everywhere. The wood is very hard, tough, and closegrained, and is especially valuable for the manufacture of small tools. 


\section{CASTANEA.}

Trees or shrubs with rough, gray, rather close bark; leaves straight-veined, undivided, prominently toothed; flowers appearing later than the leaves; staminate aments erect or spreading, loosely flowered, flowers several in the axil of each bract, calyx 4-6-parted, stamens 8-16; pistillate flowers at the base of the staminate ament or in small separate clusters, usually 3 in each involucre; ovary 4-celled, surrounded by 5-12 abortive stamens, fruit a 1-celled nut enclosed in the greatly enlarged and very prickly involucre.

1. C. Dentata (Marsh) Berkh. American Chestnut. A large tree, bark somewhat rough, and splitting into longitudinal plates; leaves oblong-lanceolate, acuminate at the apex, usually acute at the base, coarsely and sharply serrate with ascending teeth, glabrous, dark green above, lighter below; petioles stout, short; staminate aments erect, $6-10$ in. long; nuts usually 3 in each burr. FebruaryMarch. Rich soil in the upper districts. Rarely found on soils containing much lime.

2. C. pumila (L.) Willd. Chinquapin. A small tree or shrub ; leaves oblong, acute or obtuse at both ends, serrate with divergent teeth, dark green and smooth above, white-woolly below; nuts solitary, nearly globular. March-April. Common southward in rich woods.

\section{QUERCUS.}

Trees or shrubs, with entire, serrate or lobed leaves which are often persistent; staminate flowers in slender aments, each subtended by quickly deciduous bracts, and consisting of 3-12 stamens enclosed by a 4-8-parted perianth, often containing an abortive ovary; pistillate flowers solitary or in small clusters, each consisting of a 3-celled ovary with 2 ovules in each cell, though rarely more than 1 ovule matures; styles short, erect or recurved; pistillate flowers surrounded by a scaly involucre which at maturity becomes a cup enclosing the base of the fruit or sometimes a large part of it; fruit an ovate or subglobose, 1-seeded, thin-shelled nut (acorn).

A. Fruit biennial; leaves entire or with bristle-pointed lobes. 
1. Q. RUbra L. Red OAK. A large tree; leaves oval or obovate, green above, pale and slightly pubescent beneath, sinuses shallow and rounded, lobes 8-12, acuminate; petioles long; cup saucer-shaped, with fine scales; acorn ovate or oblong, about 1 in. long. April-May. Cornmon; wood not valuable; leaves turning red after frost and often remaining on the tree through the winter.

2. Q. velutina Lam. Black OAK. A large tree with rough, dark brown outer bark and thick, bright yellow inner bark; leaves broadly oval, usually divided more than halfway to the mid-rib, sinuses rounded; lobes about 7 , sharply toothed at the apex, smooth above, usually pubescent on the veins beneath; cup hemispherical or topshaped, with coarse scales, short-peduncled, enclosing about half the roundish acorn. April-May. Common; wood not valuable, but the inner bark used for tanning and dyeing.

3. Q. digitata (Marsh) Sudw. Spanish OAK. A small or medium-sized tree with leaves 3-5-lobed at the apex, obtuse or rounded at the base, grayish downy beneath, lobes lanceolate and often falcate, sparingly cut-toothed; cup top-shaped, with coarse scales, enclosing about half the nearly globose acorn. April-May. Common in dry woods. Foliage quite variable in outline and lobing; bark valuable for tanning.

4. Q. Nigra L. ВLACK-JACK ОАк. A small tree; leaves obovate, usually with three rounded lobes at the apex, the lobes bristle-pointed, rounded, or slightly cordate at the base, rusty-pubescent beneath, shining above, coriaceous, short-petioled ; cup top-shaped, short-peduncled, with coarse and truncate scales, enclosing about one-third of the oblong-ovate acorn. April-May. An almost worthless tree, its presence indicating a thin and sterile soil.

5. Q. Phellos L. Willow OAK. A tree of medium size, leaves lanceolate or elliptical, scurfy when young and becoming smooth with age; very short-petioled; cup shallow, sessile; acorn subglobose. March-April. Wet soil; often planted for shade.

B. Fruit annual; leaves not bristle tipped, though often mucronate.

6. Q. Alba L. White OAK. A large tree with light gray bark; leaves obovate-oblong, 3-9-lobed, lobes rounded and mostly entire, bright green above, paler below, short-petioled; cup hemispherical, scales rough, woolly when young, but becoming glabrous with age; acorn oblong-ovate, about 1 in. long. March-April. Common in damp soil; wood strong and durable; one of the most valuable timber trees. 
7. Q. minor (Marsh) Sarg. Post OAK. A tree of medium size, with rough, gray bark; leaves broadly obovate, deeply lyratepinmatifid into 5-7 rounded, divergent lobes, upper lobes much the longer, smooth above, tomentose beneath, petioles about $1 \mathrm{in}$. long; cup hemispherical, nearly sessile; acorn ovoid, 2-3 times as long as the cup. March-April. On dry soil; wood hard and valuable.

8. Q. LYRATA Walt. Swamp OAK. A large tree with gray or reddish bark, leaves obovate-oblong, deeply pinnatifid, lobes narrow, often toothed, thin, glabrous above, white tomentose beneath; cup round-ovate, scales cuspidate, enclosing nearly the whole of the depressed-globose acorn. March-April. On wet soil ; wood strong and very durable.

9. Q. Prinus L. Swamp Chestnut OAK. A large tree, with brown, ridged bark; leaves oblong or oblony-lanceolate, rather obtuse, crenately toothed, minutely downy beneath, petioles slender, about 1 in. long; cup hemispherical, peduncles longer than the petioles, scales acute, tubercular, appressed; acorn oblong, acute, 1 in. or less in length, edible. March-April. Common on low ground. Wood strong and valuable.

10. Q. acuminata (Michx.) Sarg. Yellow Chestnut Oak. A tree of medium or large size with gray bark, leaves oblong or oblanceolate, usually acute at the apex and obtuse or rounded at the base, coarsely and evenly toothed; veins straight, impressed above and prominent beneath; petioles slender; cup hemispherical, sessile or short-peduncled, with flat scales, $\frac{1}{2} \mathrm{in}$. broad, enclosing about half the ovoid acorn which is $\frac{2}{3}-\frac{3}{4}$ in. long. March-April. Common on dry soil; wood close-grained, durable, and valuable.

11. Q. Virginiana Mill. Live Oak. A large tree with rough gray or brown bark and a low spreading head; leaves coriaceous, evergreen, oblong or oblanceolate, often somewhat 3-lobed on young trees, margin revolute, dark green and shining above, pale below; petioles short, stout; fruit often in short racemes, cup top-shaped, scales closely appressed, hoary, peduncles $\frac{1}{2}-1$ in. long; acorn from subglobose to oblong, the longer form occurring on the younger trees. March-April. On low ground near the coast; wood very hard and durable; valued for ship-building.

\section{ULMACEA. ELM FAMILY.}

Trees or shrubs with watery juice, alternate, simple, petiolate, serrate, stipulate leaves which are usually 2-ranked; and small, perfect or polygamous, apetalous flowers ; calyx of 3-9 
sepals which are distinct or partly united, stamens as many as the sepals and opposite them ; ovary 1-2-celled, styles 2, spreading; fruit a samara, nut, or drupe.

\section{ULMUS.}

Trees with straight-veined, inequilateral, doubly serrate leaves; stipules early deciduous; flowers perfect, calyx bellshaped, 4-9-cleft, stamens slender, exserted; ovary compressed, styles 2, spreading, fruit membranaceous, flat, winged on the edge.

1. U. Americana L. White Elm. A large tree with gray bark and smooth or slightly pubescent twigs ; leaves oval or obovate, abruptly acuminate at the apex, obtuse and oblique at the base, slightly rough above, soft pubescent or soon glabrous beneath; flowers in close fascicles, peduncles slender, smooth; fruit oval or obovate, with 2 sharp, connivent teeth at the apex, wing reticulateveined, downy on the margin. Flowers February-March; fruit ripe April-May. In moist, rich soil. A widely planted ornamental tree; wood strong but warping badly, and not durable when exposed.

2. U. Alata Michx. Winged Elm. A small tree with branches corky-winged, leaves small, ovate-lanceolate, acute, sharply serrate, base nearly equal-sided, rough above, pubescent beneath, nearly sessile; flowers in small clusters, fruit oblong, downy on the sides, ciliate on the edges. Flowers February-March; fruit April-May. On rich soil. Occasionally producing a second set of flowers and fruit from September to November.

3. U. Fulva Michx. Slippery Elm. A tree of medium size with rough pubescent twigs, and rusty-tomentose bud scales; leaves large, thick, very rough above, pubescent beneath, ovate or obovate, acuminate at the apex, inequilateral, obtuse or somewhat cordate at the base, coarsely and doubly serrate, calyx lobes and pedicels pubescent; fruit broadly oval, pubescent over the seed, the wing smooth. February-March. Inner bark very fragrant when dried, and a popular domestic remedy.

\section{CELTIS.}

Trees or shrubs, with entire or serrate, petiolate leaves; flowers greenish, axillary, on wood of the same season, the staminate in small clusters, the fertile single or 2-3 together. 
1. C. occidentalis L. Hackberry. A large or medium-sized tree having much the appearance of an elm, bark dark and rough; leaves ovate, acuminate at the apex, abruptly obtuse and inequilateral at the base, sharply serrate, often 3-nerved from the base, glabrous above, usually somewhat pubescent below ; fruit a small, dark purple drupe. March-April. On rich soil.

2. C. Mississippiensis Bosc. Southern Hackberry. A tree, usually smaller than the preceding, bark gray, often very warty; leaves broadly lanceolate or ovate, long-acuminate at the apex, obtuse or sometimes cordate at the base, entire or with very few serratures, glabrous on both sides, 3-nerved ; fruit a purplish-black, globose drupe. March-April.

\section{MORACE Æ. MULBERRY FAMILY.}

Trees, shrubs, or herbs, usually with milky juice, alternate leaves, large deciduous stipules and small monœcious or diœcious flowers crowded in spikes or heads or enclosed in a fleshy receptacle; staminate flowers with a 3-4-lobed calyx, stamens $3-4$, inserted on the base of the calyx, filaments usually inflexed in the bud, straightening at maturity ; pistillate flowers 3-5-sepalous; ovary 1-2-celled, 1-2-ovuled; styles 2 , receptacle and perianth often fleshy at maturity.

\section{MORUS.}

Trees or shrubs with milky juice, rounded leaves, and monœcious flowers in axillary spikes ; staminate flowers with a 4-parted perianth, and 4 stamens inflexed in the bud; pistillate flowers with a 4-parted perianth which becomes fleshy in fruit, ovary sessile, stigmas 2 , linear, spreading; the fleshy perianth enclosing the ovary at maturity.

1. M. rubra L. Red Mulberry. A small tree; leaves cordateovate, often 3-5-lobed on vigorous shoots, acuminate at the apex, serrate, rough above, white tomentose beneath; mature fruiting spikes oblong, drooping, dark red or purple, edible. On rich soil. Flowers March-April ; fruit May-June. Wood very durable, bearing exposure to the weather. 
2. M. Alba L. White Mulberry. A small tree; leaves ovatecordate, acute at the apex, rounded and often oblique at the base, serrate or sometimes lobed, smooth and shining on both sides, mature fruit light red or white. April-May. Fruit June-July. Introduced and common about old dwellings.

\section{TOXYLON.}

A small tree with milky juice; leaves alternate, petioled, spines axillary; flowers diœeious; staminate flowers in short axillary racemes; calyx 4-parted; stamens 4, inflexed in the bud; pistillate flowers in axillary, pedunculate, capitate clusters; calyx 4-parted, ovary sessile, style long; calyces becoming thickened and fleshy in fruit and aggregated into a large, dense, globular head.

T. pomiferum Raf. Osage Orange. A small tree with ridged, yellowish-brown bark; leaves puberulent when young, becoming smooth and shining with age, ovate or ovate-oblong, acuminate at the apex, obtuse or subcordate at the base, entire, petioled; staminate racemes about $1 \mathrm{in}$. long; pistillate flower clusters about 1 in. in diameter ; fruit yellowish, tubercled, 3-4 in. in diameter. In rich soil. April-May; fruiting in October or November. Native in Texas and extensively planted for hedges. Wood very durable when exposed to the weather, and used for fence posts. As the wood does not swell or shrink with changes in its moisture, it is valued highly for wheel hubs, etc.

\section{BROUSSONETIA.}

Small trees with milky juice; leaves alternate, petioled; flowers diœcious; staminate in cylindrical spikes, with a 4-cleft calyx, 4 stamens and a rudimentary ovary; pistillate flowers in capitate clusters, calyx 3-4-toothed, ovary stalked, style 2-cleft, fruit in a globular head.

B. Papyrifera (L.) Vent. Paper Mulberry. A round-headed tree with yellowish-brown bark; leaves cordate, often irregularly 2-3-lobed, serrate, rough above, tomentose beneath, long-petioled; staminate spikelets peduncled, 2-3 in. long; pistillate heads stout, peduncled, about $1 \mathrm{in}$. in diameter. April-May. Introduced from Asia and very common about old dooryards. 


\section{HUMULUS.}

Perennial, herbaceous twining vines with watery juice; leaves opposite, palmately veined; flowers diœcious ; staminate flowers in loose axillary panicles, calyx 5-parted, stamens 5, erect in the bud ; pistillate flowers in short axillary and solitary spikes, 2 flowers in the axil of each bract; perianth entire, stigmas 2, filiform.

H. Lupulus L. Hop-vine. Stem rough, twining high, leaves rough, palmately 3-7-cleft or lobed, serrate, petiole nearly as long as the leaf; staminate panicles $3-5$ in. long, pistillate panicles (hops) $1 \frac{1}{2}-2$ in. long in fruit, and then consisting of the greatly enlarged calyces and bracts enclosing the small achenes; fruiting parts sprinkled with yellow, aromatic, resinous grains, which give the hops their peculiar value. June-July.

Ficus Carica L., the cultivated fig, also belongs to this family.

\section{URTICACE $\approx$. NETTLE FAMILY.}

Herbs with watery juice, stem and leaves often clothed with stinging hairs ; undivided, stipulate leaves ; small, greenish, imperfect, apetalous flowers in axillary clusters; calyx of the staminate flowers, 4-5-parted or 4-5-sepalous; stamens as many as the sepals and opposite them, filaments inflexed in the bud and straightening at maturity, anthers 2-celled; calyx of pistillate flowers $2-4$-sepalous; ovary sessile, 1 -celled, stigma simple or tufted; fruit an achene commonly enclosed in the dry, persistent calyx.

\section{URTICA.}

Annual or perennial herbs; leaves with stinging hairs, opposite, petioled, several-nerved, dentate, or incised, stipulate; flowers monœcious or diœcious; calyx of the staminate flowers 4-parted, stamens 4, inserted around a rudimentary ovary; pistillate flowers with 4 unequal sepals, the inner ones dilated in fruit; achenes smooth, compressed.

1. U. dioica L. Large Stinging Nettle. Perennial; stem and leaves very bristly, stem stout, $2-3 \mathrm{ft}$. tall, 4 -angled, pubescent 
above; leaves cordate, acute at the apex, coarsely serrate, 3-nerved, downy beneath, petioles slender, shorter than the blades; stipules lanceolate; flowers in much-branched, panicled spikes, mostly diœcious. June-July. In waste places, especially on rich soil.

2. U. urens L. Small Nettle. Annual; stem stout, 4-angled, hairy, 12-18 in. tali, with few stinging hairs; branches slender; leaves elliptical or ovate, serrate or incised, 3-5-nerved, acute or obtuse at the ends, thin, hairy, petioles often as long as the blades; stipules short; flower clusters axillary, in pairs, loose, mostly shorter than the petioles. February-May. On damp soil in waste places.

\section{BCEHMERIA.}

Perennial herbs, with opposite or alternate, petioled, 3-nerved leaves, destitute of stinging hairs; flowers monœcious or diøecious, in axillary clusters, similar to those of Urtica.

B. cylindrica (L.) Willd. False Nettle. Stem erect, branching, pubescent, 1-3 ft. tall ; leaves often opposite and alternate on the same plant, ovate or ovate-lanceolate, acuminate at the apex, rounded and 3-nerved at the base, coarsely serrate with rounded teeth, thin ; flowers in axillary spikes; staminate spikes often leafy near the summit, sometimes as long as the leaves; pistillate spikes short, compact. June-July. Common in moist thickets.

\section{LORANTHACE正. MISTLETOE FAMILY.}

Parasitic shrubs or herbs; leaves opposite, coriaceous, without stipules; flowers monœcious or diœecious, clustered or solitary; perianth of both calyx and corolla, or of a calyx only, or sometimes wanting; calyx tube adherent to the ovary, sepals $2-8$; stamens as many as the sepals, and opposite them ; ovary 1-celled, ovule 1; fruit a berry.

\section{PHORADENDRON.}

Evergreen, shrubby plants, parasitic on trees; branches greenish, jointed, and very brittle; leaves coriaceous ; flowers diœcious, in short, jointed spikes; staminate flowers globular, calyx 2-4-lobed, stamens sessile at the base of the lobes, 
anthers transversely 2-celled; pistillate flowers with the ovary inferior, stigma sessile; berry 1 -seeded.

P. Flavescens (Pursh.) Nutt. Mistletoe. Very round, bushy, branches very brittle at the joints, opposite or whorled, 6 in.-2 ft. long; leaves flat, coriaceous or somewhat fleshy, nearly veinless, obovate, entire, with short petioles; flowering spikes solitary or 2-3 together in the axils of the leaves; berry globose, white, glutinous. April-May. Parasitic on many deciduous trees.

\section{ARISTOLOCHIACE E. BIRTHWORT FAMILY.}

Herbaceous plants, acaulescent or with twining and leafy stems; leaves alternate, exstipulate, petioled, mostly roundish or reniform; flowers axillary, solitary or clustered, perfect, regular or irregular ; calyx tubular, 3 or 6 -lobed, usually colored; petals none; stamens $6-12$, inserted on the ovary; pistils 1 , ovary mostly 6 -celled, many-seeded.

\section{ASARUM.}

Perennial, acaulescent, aromatic herbs with slender, branching rootstocks ; leaves long-petioled, from reniform to hastate; flowers axillary, peduncled ; calyx regular, 3-lobed, witheringpersistent; stamens 12 , the filaments partially united with the style and usually prolonged beyond the anthers; ovary 6-celled with parietal placentæ, many-seeded; mature capsule globose, often somewhat fleshy.

1. A. Virginicum L. Virginia Asarum. Leaves evergreen, 1-3 to each plant, glabrous, mottled, round-cordate, entire, $2-3 \mathrm{in}$. long and broad; petioles glabrous or pubescent along one side, $3-7$ in. long; flowers nearly sessile, greenish without, dull purple within, $\frac{2}{3}-\frac{3}{4}$ in. long, tube inflated below, narrowed at the throat, lobes spreading. April-May. Rich, shady woods in the upper districts.

2. A. arifolium Michx. Ginger-Root. Leaves cordate or halberd-shaped, 2-4 in. long, usually mottled; petioles pubescent, $3-8$ in. long; flowers pitcher-shaped, about 1 in. long, peduncled, dark purple within, lobes short and rounded. March-April. Shady woods in the lower districts. 


\section{ARISTOLOCHIA.}

Erect or twining perennial herbs or woody vines; leaves alternate, cordate at the base, palmately nerved, petiolate, entire; flowers irregular, solitary or in small clusters ; calyx. more or less adherent to the ovary, tubular, irregular; stamens mostly 6 , sessile, adnate to the angled and fleshy 3-6lobed or angled stigma; capsule naked, 6-valved, seeds very numerous.

1. A. Serpentaria L. Virginia Snakeroot. Stem erect, branching, pubescent, 10-18 in. high ; leaves short-petioled, ovate to linear-lanceolate, cordate or hastate at the base, thin, smooth; lower leaves scale-like; flowers near the base of the stem on bracted peduncles; calyx tubular, bent like the letter S, inflated below, then contracted, again enlarging at the throat, limb short, spreading, 3-lobed, dull purple; anthers in pairs; capsule subglobose, ridged. JuneJuly. Rich, shady woods. The aromatic-stimulant root often used in medicine.

2. A. tomentosa Sims. Dutchman's Pipe. Stem woody, climbing high, branches and leaves tomentose; leaves cordate, prominently veined, $3-5 \mathrm{in}$. long and broad; flowers axillary, mostly solitary, on slender peduncles; calyx bent in the shape of a pipe, yellowish-green with a dark purple throat, limb unequally 3-lobed, rugose, reflexed; anthers in pairs below the 3 spreading lobes of the stigma; capsule oblong. April-May. Stems sometimes 30 feet long.

\section{POLYGONACE E. BUCKWHEAT FAMILY.}

Herbs, shrubs, or trees; leaves simple, usually entire and alternate, but sometimes opposite; stipules commonly membranaceous, and sheathing the swollen joints of the stem, but sometimes wanting; flowers small, perfect, monœcious or diœcious; calyx of $2-6$ sepals which are often more or less united, sometimes petal-like and persistent; petals none; stamens 4-12, inserted on the base of the calyx; ovary single, 1-celled, styles or stigmas $2-3$; fruit a lenticular or 3 -angled achene. 


\section{RUMEX.}

Annual or perennial herbs, stems grooved, usually branching above; leaves alternate, hastate-lobed or entire; flowers perfect or polygamo-diœcious, in whorls on jointed pedicels ; calyx of 6 sepals, the outer 3 being usually colored and petallike, while the inner 3 form a persistent, winged, 3-valved covering for the fruit; stamens 6 ; styles 3 , stigmas many cleft.

1. R. Acetosella L. Sheep Sorrel. Erect, annual or perennial herbs with creeping rootstocks; stem simple or branched, glabrous; leaves petioled, narrowly hastate, usually widest above the middle, the apex acute or obtuse, upper stem leaves often nearly linear, and not lobed; flowers diœcious, small, in terminal, naked, panicled, interrupted racemes; calyx greenish ; the pistillate panicles becoming reddish; fruit less than $\frac{1}{12}$ in. long, granular, longer than the calyx. April-August. A common introduced weed, in dry fields and on sour soils. Foliage very acid.

2. R. verticillatus L. Swamp Dock. Perennial; stem stout, smooth, erect or ascending, 3-5 ft. tall ; lower leaves oblong, obtuse at the apex and usually cordate at the base, long-petioled, often 12-18 in. long, upper leaves narrower and often acute at both ends; flowers perfect or polygamous, in dense whorls, pedicels slender, $\frac{1}{2}-\frac{2}{3}$ in. long, tapering downward, reflexed at maturity; calyx green, the valves broadly deltoid, abruptly pointed, reticulated, a distinct, long and narrow tubercle on the back of each. May-June. Swamps and wet ground.

3. R. obtusifolius L. Bitter Dock. Perennial; stem erect, stout, branched and somewhat roughened above, $2-4 \mathrm{ft}$. tall; lower leaves ovate-oblong, obtuse at the apex, cordate at the base, longpetioled; the upper leaves lanceolate or lanceolate-oblong, acute at each end, short-petioled, often wavy on the margin; flowers perfect or polygamous, in open, panicled racemes, the lower whorls scattered, the upper more crowded; pedicels slender, a little longer than the fruit; wings hastate, $\frac{1}{4}$ in. long, with a few spiny teeth on the margins, and at least one of them prominently tubercled on the back. May-August. A common naturalized weed on rich soil.

\section{POLYGONUM.}

Annual or perennial, terrestrial or aquatic herbs, with tumid joints and simple, alternate, entire leaves; the sheathing stip- 
ules (ochreæ) often lacerate or fringed; flowers perfect, usually white or rose-colored, each flower or cluster subtended by a membranaceous bract similar to the ochreæ of the leaves; calyx mostly 5-parted, the divisions petal-like, erect and persistent; stamens $3-9$; styles 2-3-parted ; fruit lenticular or 3 -angìed.

1. P. Persicaria I. Lady's Tear-thumb. Annual; stem erect or ascending, simple or branched, nearly or quite smooth, 12 18 in. tall ; leaves lanceolate or oblong, short-petioled, roughened on the edges and veins, punctate, usually marked with a dark, triangular spot near the middle; ochreæ bristly ciliate; flowers in erect, densely flowered spikes or racemes 1-2 in. long, rose-color to dark purple, peduncles smooth; achenes lenticular or 3-angled, smooth and shining. June-July. Around dwellings.

2. P. punctatum Ell. Water Syartweed. Perennial; stem creeping and rooting at the base, nearly smooth, slender, 1-3 ft. long; leaves lanceolate or oblong, acuminate at the apex, nearly sessile, rough on the margins and nerves, dotted with pellucid glands; juice acrid; ochreæ oblique, silvery, fringed with long bristles; racemes terminal, slender, loosely flowered, $2-3$ in. long; flowers greenish; stamens 8; style 3-parted; achene sharply 3-angled, smooth and shining. June-September. Common in ditches and wet places.

3. P. orientale L. Prince's Feather. Annual ; stem hairy, branching above, $3-\overline{5} \mathrm{ft}$. tall; leaves ovate or oblong, acuminate at the apex, ciliate, petioled; ochreæ cylindrical, usually with a spreading border; flowers in long racemes, bright rose-color, showy ; stamens 7 ; style 2-cleft; achene flat, ovate or orbicular, finely reticulated and not shining. June-September. Around dwellings; escaped from cultivation.

4. P. aviculare L. K кот-grass. Annual or perennial; stem prostrate or ascending, diffuse, glabrous, 6-24 in. long; leaves small, lanceolate or linear-oblong, obtuse, nearly or quite sessile; ochreæ scarious, 2-3-cleft or lacerate; flower clusters axillary, 1-5-flowered, flowers inconspicuous, nearly sessile; calyx greenish-white, 5-parted, the lobes with white or colored borders ; stamens 5-8; style 3-parted; achene 3 -angled, not shining. May-September. A common weed in dooryards and where the ground is tramped.

5. P. dumetorum L. False Buckwheat. Perennial; stems slender, twining, branched, 2-10 ft. long; leaves ovate, acuminate at the apex, cordate to halberd-shaped at the base, long-petioled ; ochreæ cylindrical, truncate; flowers in axillary, more or less compound and leafy racemes; calyx greenish-white, the outer lobes winged and decurrent on the pedicel; stamens 8 ; stigmas 3 ; achene 3 -angled, 
black, smooth and shining. May-September. Margins of fields and thickets.

6. P. hirsutum Walt. Hairy Smartweed. Perennial; stems erect, branching, hirsute with spreading hairs, 2-3 ft. tall; leaves lanceolate, rounded at the base, hairy, especially on the margins and veins, nearly sessile; ochreæ hirsute, margin with a fringe of long hairs; flowering spike linear, erect, rather closely flowered; calyx white; stamens 8 ; achene 3 -angled. June-August. Common about ponds in pine barrens.

\section{BRUNNICHIA.}

Perennial; stem smooth, climbing by tendrils at the ends of the branches; leaves alternate, entire, petioled; ochreæ small or wanting; flowers greenish, in axillary and terminal racemes, on slender pedicels ; calyx 5-parted, becoming much enlarged, and almost woody in fruit; stamens usually 8 ; styles 3 ; mature achene 3 -angled, enclosed by the persistent calyx.

B. Cirrhosa Banks. Brunnichia. Stem somewhat woody, climbing 15-20 ft.; leaves ovate or cordate, slightly pubescent beneath ; sheaths obsolete; racemes drooping, 2-6 in. long ; flowers in clusters of $2-5$, pedicels recurved; mature fruit coriaceous, $1 \mathrm{in}$. or more in length. April-May. River banks.

\section{CHENOPODIACEA. GOOSEFOOT FAMILY.}

Annual, or perennial by a slightly woody rootstock; leaves simple, alternate or opposite, exstipulate; flowers perfect, polygamous, monœcious or diœcious, small, greenish, sometimes irregular, occasionally solitary in the axils but usually in panicled spikes; calyx 2-5-lobed or sometimes a single sepal; petals none; stamens as many as the lobes of the calyx and opposite them, or sometimes fewer; ovary free from the calyx, 1-celled, styles $1-3$; fruit a utricle. A family containing many common weeds, some of which are immi- 
grants from tropical countries, and also the common garden beet (Beta vulgaris), which is a native of Europe.

\section{CHENOPODIUM.}

Annual or perennial herbs; stems erect or diffuse; leaves alternate, usually white-mealy; flowers small, greenish, in panicled spikes; calyx 3-5-parted, the lobes often slightly fleshy and keeled; stamens 5, filaments filiform; styles 2-3, distinct or united at the base; seed lenticular.

1. C. Album L. Pigweed. Annual; stem erect, branching, striate or furrowed, 1-5 ft. tall; leaves rhombic-ovate, acute at the base, irregularly toothed, or the upper becoming narrower and entire, more or less coated with white powder; petiole nearly as long as the blade; flowers in small, panicled spikes; calyx 5-angled, sepals strongly keeled; seed black and shining. June-September. A common weed in cultivated ground.

2. C. anthelminticum L. Wormseed. Perennial; stem stout, erect, much branched, 2-4 ft. tall; leaves oblong or lanceolate, acute at each end, coarsely and sharply toothed or incised, upper leaves smaller; flowers very numerous, in linear, panicled spikes which are often leafy-bracted; calyx not keeled; seeds with obtuse margins, smooth and shiny; whole plant very aromatic-fragrant. July-September. In waste places.

\section{SALICORNIA.}

Herbs, annual or perennial; stems fleshy, glabrous, branches opposite, jointed; leaves reduced to small, opposite scales; flowers perfect, 3-6 together, sunken into the upper joints of the stem, forming terminal spikes; calyx thin, becoming spongy in fruit; stamens $1-2$; styles or stigmas 2 ; fruit a utricle enclosed in the spongy calyx; whole plant salty to the taste.

1. S. ambigua Michx. Glasswort. Perennial; stem slightly shrubby at the base, the branches ascending or erect, nearly simple, joints truncate, dilated above, slightly 2-toothed; fruiting spikes cylindrical or obtuse, $\frac{1}{2}-1 \frac{1}{2}$ in. long, the terminal ones sessile, the lateral peduncled. July-September. Salt marshes along the coast. 


\section{SALSOLA.}

Herbs, annual or perennial; stems diffusely branched; leaves alternate, fleshy; flowers solitary in the axils, sessile, perfect, 2-bracted; calyx 5-parted, the lobes becoming winged; stamens 5 ; style slender, stigmas 2 ; utricle flattened at the apex, enclosed in the persistent calyx.

S. Kali L. Saltwort. Annual; stem very diffuse, smooth or slightly pubescent, 1-2 ft. high ; leaves dull or grayish-green, succulent, subulate, spine-tipped, $\frac{1}{2}-1 \mathrm{in}$. long; flowers solitary in the axils; the calyx with a dilated, membranaceous, rose-colored wing. JuneSeptember. Sandy sea beaches.

\section{AMARANTACE $Æ$. AMARANTH FAMILY.}

Usually herbs, or a few species becoming shrubby; leaves simple, alternate or opposite, exstipulate; flowers perfect or imperfect, mostly greenish and inconspicuous and crowded in bracted spikes or heads; sepals 3-5, free or united at the base; petals none; stamens $1-5$, opposite the sepals, filaments distinct or united; pistil 1, ovary subglobose, 1-celled, 1-seeded; fruit a utricle, usually circumscissile.

\section{AMARANTUS.}

Herbs, annual; stems erect or diffuse; leaves alternate, usually petioled, entire and mucronate; flowers greenish or purplish, crowded in dense axillary and terminal spikes or clusters; sepals 2-5, distinct; stamens $2-5$; stigmas $2-3$, recurved; utricle 2-3-toothed at the apex, circumscissile, usually enclosed by the calyx.

1. A. hybridus L. Stender Pigweed. Annual; stem smooth or nearly so, erect, branching, 2-6 ft. tall, often purplish; leaves ovate or ovate-oblong, obtuse, notched or tapering at the apex, mucronate, pale beneath, petioles long and slender; flowering spikes numerous, panicled, the terminal one long and slender, the others shorter; sepals acuminate, shorter than the subulate bracts; utricle 
slightly rugose. July-October. An introduced weed in waste ground.

2. A. spinosus L. Spiny Amaranth. Annual; stem smooth or slightly pubescent above, stout, erect, much branched, succuleut, 1-3 ft. tall; leaves ovate or lanceolate, acute at both ends or sometimes emarginate at the apex, blotched with purple above, longpetioled, spiny in the axils; flowers in numerous capitate, nearly sessile clusters, the bracts, sepals, and utricle about equal in length. June-October. A troublesome weed from tropical America.

\section{FROELICHIA.}

Herbs, annual; stems slender, erect, branching above, woolly; leaves opposite, entire, exstipulate; flowers in dense spikes terminating the peduncle-like branches, perfect, 3bracted; calyx tubular, 5-cleft, becoming spiny-tipped in fruit; stamens 5, united into a tube; ovary ovoid, stigma capitate or lacerate-fringed; fruit a 1-seeded utricle enclosed by the calyx.

F. Floridana (Nutt.) Moq. Froelichia. Stem 1-4 ft. tall, white-woolly, erect, branched and leafless above; lower leaves spatulate to lanceolate, long-petioled; stem-leaves sessile and usually linear, entire; flowering spikes from opposite branches, lengthening with age; bracts blackish; calyx very white-woolly. June-September. Dry, sandy ground, especially near the coast.

\section{PHYTOLACCACE 2 . POKEWEED FAMILY.}

Herbs or shrubs; leaves simple, alternate, entire, exstipulate; flowers in spikes or racemes; calyx of 4-5 distinct sepals or 4-5-parted; petals none; stamens as many as the sepals and alternate with them, or more numerous; pistil 1, simple or compound, ovules 1 in each cell; fruit (in our species) a berry. 


\section{PHYTOLACCA.}

Perennial herbs; stems tall, branching ; leaves large, entire ; flowers small, in terminal racemes, pedicels bracted; calyx of 4-5 nearly equal, persistent sepals; stamens 5-15, inserted at the base of the calyx; styles $5-12$, recurved at the apex; fruit a depressed-globose, juicy berry.

P. decandra L. Pokeweed. Stems erect, smooth, branched above, usually dark purple, $4-7 \mathrm{ft}$. tall ; root large, fleshy, poisonous ; leaves ovate-lanceolate, smooth, acute, long-petioled ; racemes peduncled, many-flowered, opposite the leaves, flowers white, becoming purplish ; stamens 10 , shorter than the sepals; styles 10 , carpels 10 ; fruit a dark purple berry. June-September. A weed on waste ground. The young branches are often eaten like asparagus, and the root, known as " garget root," is used in medicine.

\section{PORTULACACE 2 . PURSLANE FAMILY.}

Herbs ; stems fleshy or succulent; leaves alternate or opposite; flowers perfect, regular, unsymmetrical; sepals commonly 2 , sometimes 5 ; petals $3-6$, hypogynous, entire or emarginate; stamens hypogynous, as many as the petals and opposite them, or indefinite; pistil 1 , styles $3-6$, mostly united below, ovary 1-5-celled, few-many-seeded; fruit a membranaceous, circumscissile capsule.

\section{CLAYTONIA.}

Perennial; stem simple, smooth, erect, 4-10 in. high; leaves 2, opposite, smooth, succulent; flowers in a terminal raceme; sepals 2 , ovate, persistent; petals 5 , sometimes coherent at the base; stamens 5 , inserted on the base of the petals; style 3-cleft, ovary 1-celled, 3-6-seeded.

C. Virginica L. Spring Beauty. Stem simple, erect from a deep, tuberous root; the 2 stem-leaves narrowly elliptical, 3-6 in. long, smooth, fleshy; basal leaves occasionally produced; flowers 
on short pedicels, petals white or pink, with darker veins, $\frac{1}{4}-\frac{3}{8}$ in. long, emarginate ; capsule shorter than the persistent sepals. MarchApril. Common in rich woods.

\section{PORTULACA.}

Annual; stems low, diffuse and spreading, succulent; leaves entire, mostly alternate; flowers terminal ; sepals 2 , united at the base and coherent with the ovary; petals usually 5 , inserted on the calyx, fugacious; stamens 8-20, inserted on the calyx; style 3-8-parted, capsule globose, 1-celled, manyseeded.

1. P. oleracea L. Purslane. Stems prostrate, diffuse, fleshý; leaves alternate, flat, obovate or cuneate; flowers solitary, sessile, opening in bright sunshine in the morning, and usually withering before noon; sepals broad, acute; petals yellow; stamens 10-12; capsule very many-seeded, seeds small, rugose. April-October. A common garden weed.

2. P. Grandiflora Hook. Garden Portulaca. Stems succulent, erect or ascending, densely hairy or nearly smooth, 3-6 in. long; leaves alternate, terete, fleshy, $\frac{1}{2}-1$ in. long; flowers 1-2 in. wide, white, yellow, or red, showy, opening only in sunlight. The summer months. Common in cultivation and often growing spontaneously.

\section{CARYOPHYLLACE E. PINK FAMILY.}

Annual or perennial herbs; stems tumid at the nodes; leaves opposite or whorled, often connate, entire; stipules dry and scarious or none; flowers cymose, usually perfect; sepals 4 5 , persistent, distinct or united into a tube; petals as many as the sepals or none; stamens as many as the sepals and opposite them, or twice as many, or sometimes fewer; ovary 1, free, usually 1-celled, sometimes 3-5-celled, placentæ central, styles 2-5; fruit dry, 1-many-seeded.

\section{AGROSTEMMA.}

Annual; stem pubescent, branching above; leaves linearlanceolate or linear, pubescent, sessile; flowers showy, on 
long and naked peduncles in terminal corymbs; calyx tubular, the tube oblong, 10-ribbed, lobes elongated, foliaceous, deciduous; petals 5, shorter than the calyx lobes, entire; stamens 10 ; styles 5 , capsules 1-celled.

A. Githago L. Conn Cockle. Stem erect, rather slender, 1$3 \mathrm{ft}$. tall, gray with long, appressed hairs; leaves linear-lanceolate, acuminate, erect, $2-4$ in. long; petals obovate, emarginate, purple; capsule 5-toothed, many-seeded, seeds black. June-July. An introduced weed, common in grain fields.

\section{SILENE.}

Annual or perennial herbs ; stems erect, or decumbent and diffuse; leaves often connate or whorled; flowers clustered or solitary, usually pink or white ; calyx tubular, more or less inflated, 5-toothed, 10-nerved, bractless ; petals 5, long-clawed, and, with the ten stamens, inserted at the base of the ovary; styles 3 , ovary 1-celled or 3-celled at the base, opening by 6 teeth, many-seeded, seeds usually roughened.

1. S. stellata (L.) Ait. Starry Campion. Perennial; stems erect, downy, branching above, $2-3 \mathrm{ft}$. tall; leaves in whorls of 4 , or the upper opposite, ovate-lanceolate, acuminate, sessile, ciliate on the margins; flowers in panicled cymes, white, $\frac{3}{4}$ in. broad; calyx inflated, bell-shaped, the teeth triangular; petals fimbriate on the margin, crownless. June-July. Dry fields and woods, especially northward.

2. S. Baldwini Nutt. Baldwin's Pink. Perennial; stems low, slender, villous, producing long runners from the base, $6-12 \mathrm{in}$. high; leaves opposite, spatulate or oblong, sessile ; flowers large, $1 \frac{1}{2}-$ 2 in. wide, white or pale rose-colored, on slender pedicels ; calyx tubular; petals fimbriate on the margins, crownless. April-May. In low shady woods, especially southward.

3. S. Regia Sims. Royal Catchfly. Perennial; stem stout, erect, viscid-pubescent, branched, $2-4$ ft. tall ; leaves ovate-lanceolate, acute or acuminate, the lower petioled, the upper sessile ; flowers in a narrow panicle, bright scarlet, $1 \mathrm{in}$. broad, pedicels about $\frac{1}{2} \mathrm{in}$. long; calyx cylindrical, striate, enlarged by the ripening capsule, teeth ovate, acute; petals emarginate or nearly entire, crowned; stamens and style exserted. June-July. Open woods and prairies. 


\section{SAPONARIA.}

Annual or perennial ; stems erect or diffuse; leaves usually broad; cymes densely flowered; calyx tubular, striate, 5toothed; petals 5, entire, appendaged; stamens 10 ; styles 2 ; capsule 1-celled, 4-toothed at the apex.

S. officinalis L. Bouncing Bet. Perennial; stems stout, smooth, erect, sparingly branched, 1-2 ft. tall ; leaves ovate, acute, strongly 3-5-ribbed, petioles short, broad and somewhat connate; flowers pink or white, 1 in. broad, showy, often double; petals obcordate, crowned; capsule shorter than the calyx. May-July. Naturalized about old gardens.

\section{DIANTHUS.}

Mostly perennial; stems erect, rigid; leaves narrow, and usually connate; flowers terminal, solitary or in cymose clusters; calyx several-bracted at the base, tubular, striate, 5toothed; petals 5, long-clawed, dentate or crenate; stamens 10 ; styles 2, ovary 1-celled, raised on a short stipe; capsule cylindrical.

D. barbatus L. Sweet William. Perennial, often in large clumps; stems erect, branching above, smooth, 1-2 ft. tall ; leaves lanceolate, 2-3 in. long, acute; flowers pink or white, in terminal clusters, bracts linear, as long as the calyx. May-August. Common about old gardens.

\section{CERASTIUM.}

Annual or perennial; stems diffuse, usually pubescent; leaves opposite; flowers white, peduncled, in terminal, regularly forking cymes; sepals 4-5; petals $4-5$, emarginate or 2-cleft; stamens 10 ; styles 5 or less; capsule cylindrical, 1-celled, many-seeded.

C. vulgatum L. Mouse-eared Chickweed. Annual or sometimes perennial; stems diffuse, tufted, clammy-pubescent, 6-12 in. high ; lower leaves spatulate, the upper oblong, acute or obtuse ; bracts scarious; flowers in loose cymes, pedicels becoming much longer than the calyx; sepals lanceolate, acute, about as long as the 2-cleft petals; slender capsule becoming twice as long as the calyx and curved upward. April-May. A common garden weed. 


\section{NYMPHÆACE Æ. WATER-LILY FAMILY.}

Perennial aquatic herbs; rootstocks creeping in mud; leaves entire, peltate or cordate, usually floating on the surface of the water; flowers solitary on long peduncles; sepals $3-5$; petals 5-many; ovary 1 , many-celled; seeds often enclosed in a pulpy aril.

\section{NYMPHÆA.}

Rootstock horizontal, thick, cylindrical; leaves cordate, floating or erect; flowers yellow; sepals 4-6, green on the outside, obovate, concave; petals many, hypogynous, the inner ones becoming small and stamen-like; stamens many, hypogynous; ovary cylindrical, many-celled, stigma diskshaped; fruit ovoid, seeds without an aril.

N. advena Sol. Yellow Pond Lily. Leaves oval or orbicular, rather thick, often pubescent beneath ; flowers bright yellow, 23 in. in diameter, depressed-globose; sepals 6 ; petals thick and fleshy, truncate; stamens in several rows, anthers nearly as long as the filaments. April-September. In slow streams and still water.

\section{CASTALIA.}

Rootstock horizontal, creeping extensively ; leaves floating, entire, peltate or cordate; flowers showy; sepals 4 , green without, white within ; petals many, white, becoming smaller toward the center; stamens many, the outer with broad and the inner with linear filaments; ovary many-celled, stigmas peltate and radiating ; fruit baccate, many-seeded.

C. odorata (Dryand) W. \& W. White Water-lily. Rootstock large, branched but little; leaves floating, entire, the sinus narrow and basal lobes acute, green and smooth above, purple and pubescent beneath; petioles and peduncles slender; flowers white, very fragrant, opening in the morning, 3-5 in. broad; fruit globose, seeds enclosed in a membranaceous aril. May-July. In ponds and still water. 


\section{NELUMBO.}

Rootstock thick, creeping; leaves orbicular, centrally peltate, concave above, raised above the water or floating; flowers solitary on long peduncles, raised above the water at flowering, but the maturing ovaries often submersed; flowers hypogynous; sepals and petals similar, numerous; filaments somewhat petal-like; seeds in pits in the upper surface of the top-shaped receptacle.

N. Lutea (Willd.) Pers. American Lotus. Rootstock often $3-4$ in. in diameter, horizontal ; leaves $1 \frac{1}{2}-2 \frac{1}{2} \mathrm{ft}$. broad, prominently ribbed, very glaucous above, often pubescent beneath; petioles and peduncles stout; flowers pale yellow, 5-9 in. broad; sepals and petals falling quickly; fruit top-shaped, $3-4$ in. in diameter; the seeds $\frac{1}{2}$ in. in diameter, immersed in pits in the upper surface. MayAugust. In ponds; introduced from the southwest.

\section{MAGNOLIACEÆ. MAGNOLIA FAMILY.}

Trees or shrubs; all parts more or less aromatic; leaves alternate, simple, petioled, entire or lobed; flowers solitary, large and showy, hypogynous; sepals and petals in 3 's ; stamens many; ovaries numerous, usually cohering over the elongated receptacle; fruit dry or fleshy.

\section{MAGNOLIA.}

Aromatic trees or shrubs; leaves alternate, often in clusters at the ends of the branches, entire, usually thick and leathery; stipules large, quickly deciduous; flowers terminal, showy, perfect; sepals 3 , caducous; petals $6-12$, in $2-4$ rows, concave; stamens numerous; ovaries numerous, 1-celled, 2seeded, the mature follicles opening at the beak and the fleshy seeds remaining for some time suspended by slender threads.

1. M. Fetida (L.) Sarg. Large-Flowered Magnolia. A large tree with spreading branches and a rounded top; bark nearly smooth; leaves very thick, evergreen, smooth and shining above, 
rusty-pubescent beneath, entire, oval or oblong, 6-9 in. long; flowers white, very fragrant, $6-9$ in. in diameter; petals 9 or more, obovate, concave; fruit a rusty-pubescent cone 3-4 in. long, seeds bright scarlet. April-June. Common on light soils. The name is very inappropriate, as the fragrance is delightful and the tree one of the most attractive native species.

2. M. Fraseri Walt. Long-leaved Umbrella Tree. A small tree with a slender trunk and widely spreading branches; leaves clustered at the ends of the branches, deciduous, oblong or obovate, contracted, cordate and auricled at the base, smooth on both sides, 8-12 in. long; petioles slender; flowers white and fragrant, 6 in. broad; petals longer than the sepals, spatulate or oblong, obtuse at the apex, narrowed at the base; cone 3-4 in. long, pink at maturity. May-June. In rich woods.

3. M. macrophylla Michx. Large-Leaved Umbrella Tree. A small tree with gray bark; leaves clustered at the ends of the branches, oblong or obovate, obtuse at the apex, cordate at the base, green and glabrous above, white and pubescent beneath, $1 \frac{1}{2}-3 \mathrm{ft}$. long; petioles stout; flowers white with a purple center, fragrant, 8-12 in. wide; petals oblong, obtuse, two or three times as long as the sepals; cone ovate, 4-6 in. long, bright red at maturity. AprilMay. Shady woods on light soil.

4. M. Virginiana L. Sweet Bay. A small tree with light gray bark; leaves scattered on the branches, evergreen, thick and leathery, oval or oblong, smooth and green above, white and glaucous or pubescent beneath, $4-6$ in. long; flowers white, fragrant, 2-3 in. in diameter; petals 9 , concave; cone $1 \frac{1}{2}-2$ in. long, pink. May-June. Common in swamps and along streams. The leaves often used in flavoring soups, etc.

\section{ILLICIUM.}

Aromatic shrubs; leaves evergreen, clustered at the ends of the branches, entire, exstipulate; flowers perfect; sepals 3 or 6 ; petals $9-30$ in rows of 3 ; stamens numerous, short ; ovaries 6-9, whorled, 1-celled, 1-ovuled, at length spreading.

I. Floridanum Ellis. Anise. A slender, spreading shrub, 5-10 ft. high; bark reddish-brown; leaves leathery, oblong-lanceolate, acute, smooth, 4-6 in. long; flowers on long peduncles in terminal clusters; petals many, lanceolate or linear, spreading, dark purple, $\frac{1}{2}-\frac{2}{3}$ in. long; mature fruit a whorl of 12-20 divergent, 1-seeded follicles. April-May. In sandy swamps. Whole plant very aromatic. 


\section{LIRIODENDRON.}

A large tree with rough, dark-colored bark; leaves scattered on the branches, deciduous, 3-lobed, truncate, stipulate, petioled; flowers perfect; sepals 3 , reflexed; petals 6 , erect; stamens numerous; ovaries numerous, 2 -ovuled, cohering over each other on the elongated receptacle, indehiscent, deciduous.

L. tulipifera L. Tulip Tree. The largest tree in the family; leaves orbicular in ontline, mostly 3-lobed, the terminal lobe truncate or broadly notched, usually cordate at the base, glabrous, green above, lighter beneath; petioles slender; flowers terminal, bellshaped, greenish-yellow striped with orange; petals obovate, obtuse, about as long as the sepals; mature cones ovate, acute, $2-3 \mathrm{in}$. long. May-June. Common on low ground. Often called "white wood" or, incorrectly, "white poplar." Wood valuable for making boxes and light furniture.

\section{ANONACE E. CUSTARD-APPLE FAMILY.}

Trees or shrubs with simple, alternate, entire, exstipulate leaves ; flowers perfect, axillary, solitary, hypogynous; sepals $2-3$, persistent; petals 6 , in 2 rows, deciduous; stamens many; ovaries few or many, distinct or coherent, becoming fleshy in fruit.

\section{ASIMINA.}

Shrubs or small trees; leaves deciduous; flowers niodding; sepals 3 , ovate; petals 6 , the three outer ones larger and spreading; stamens very numerous, crowded on the globular receptacle; ovaries 3-15, sessile, 1-celled, several-ovuled; fruit a large, fleshy, oblong berry, seeds large, horizontal.

1. A. triloba (L.) Dunal. Pawpaw. A small tree, 10-20 ft. high ; bark nearly smooth, lead-colored; leaves oblong-obovate, acute at the apex, obtuse at the base, rusty-pubescent when young and becoming smoother with age, 6-10 in. long ; flowers on branches of the previous season, appearing before or with the leaves; the short peduncles and the sepals brown-pubescent; petals purple, obovate, 3-4 times longer than the sepals; fruit 3-5 in. long, edible when ripe. March-April. Common on banks of streams. The bark is very tough and is often used in the place of rope. 
2. A. Parviflora (Michx.) Dunal. Dwarf Pawpaw. A shrub 2-4 ft. high ; leaves oblong-obovate, abruptly acute, rusty-pubescent when young; flowers greenish-purple, on shoots of the previous season; outer petals obovate, twice the length of the sepals, the inner petals narrower and shorter; fruit oblong or pear-shaped, few-seeded, not edible. March-April. In dry woods.

\section{RANUNCULACEE. CROWFOOT FAMILY:}

Herbs or woody climbing vines, with a watery, acrid juice ; leaves alternate, usually divided or compound ; petioles dilated at the base ; stipules none ; flowers perfect, regular or irregular, hypogynous; sepals 3-15, deciduous, often petal-like; petals 5-15, deciduous, often wanting; stamens many; ovaries distinct, usually numerous, but sometimes few, 1-celled, 1-many-seeded; fruit dry or fleshy.

Flowers irregular Flowers regular.

Fruit a berry .

Fruit an achene.

Achenia plumose-tailed

Achenia ribbed.

Flowers perfect

Flowers imperfect

Achenia not ribbed.

Sepals petaloid.

Involucre near the flower

Involucre remote.

Sepals herbaceous.

Fruit a 2-seeded follicle .

Fruit several-seeded follicles .

Follicles 2 .

Follicles 5 or more.

Leaves simple.

Leaves compound

\section{Delphinium.}

III. Actæa.

IX. Clematis.

VIII. Syndesmon.

XI. Thalictrum.

VII. Hepatica.

VI. Anemone.

X. Ranunculus.

II. Isopyrum.

XII. Pæonia.

I. Caltha.

IV. Aquilegia. 


\section{CALTHA.}

Perennial aquatic herbs; leaves undivided; sepals 5-9, petal-like; petals none; pistils 5-15, stigmas sessile; ovaries inany-seeded.

C. Palustris L. Marsh Marigold. Stem thick, smooth, hollow, furrowed, 10-15 in. high ; leaves long-petioled, round or broadly reniform, smooth, thick, toothed or nearly entire; flowers bright yellow, showy, $1 \frac{1}{2}$ in. broad; stamens numerous; follicles oblong, pointless, compressed, many-seeded. April-May. In wet meadows and swamps. More common northward.

\section{ISOPYRUM.}

Perennial from small tubers; stem slender, smooth; leaves alternate, compound; flowers axillary and terminal, solitary, white; sepals $4-6$; petals minute or wanting; pistils $2-20$; follicles sessile, 2 -seeded.

I. Biternatum T. \& G. Spring Beauty. Stem erect, rarely branched, 6-10 in. high ; radical leaves on long petioles, twice 3-compound; stem leaves sessile, ternate; leaflets ovate or obovate, 2-3lobed ; flowers white, 1 in. wide; sepals oval, petal-like; petals none; stamens many ; pistils 3-6 ; follicles spreading at maturity, pointed. April-May. Shady woods. Resembling Syndesmon thatictroides in general appearance, but distinguished by the ovary being 2-seeded.

\section{ACT ÆA.}

Perennial; stem simple; leaves 2-3-ternate; leaflets ovate, sharply cut or toothed; flowers white, in a short and thick terminal raceme; sepals $4-5$, soon deciduous; petals 4-10, small; pistil single, stigma 2-lobed; fruit a many-seeded berry.

A. alba Bigel. Baneberry. Stem erect, smooth or nearly so, 18-24 in. high; leaves large and spreading; leaflets thin; racemes very broad; petals slender, truncate; pedicels red, thickened in fruiting; berries white. May_June. In rich woods; more common in the mountain regions. 


\section{AQUILEGIA.}

Perennial herbs; stems erect, branching, 1-2 ft. high ; leaves compound; flowers showy, nodding; sepals 5 , colored; petals 5 , prolonged downward as a hollow, curved spur; stamens numerous, the inner ones longer; pistils 5 ; follicles manyseeded.

1. A. Canadensis L. Columbine. (Sometimes wrongly called honeysuckle.) Stems several or many in a clump, branching, smooth or-slightly pubescent, leafy; radical leaves long-petioled, biternate; stem leaves short-petioled, ternate; leaflets roundish or obovate, lobed; flowers terminal or somewhat corymbed, large and showy, scarlet and yellow; sepals ovate, acute; petals horn-shaped, attached by one edge of the mouth; stamens and styles exserted; follicles erect and somewhat divergent at maturity. April-May. Rocky woods and river banks.

2. A. vulgaris L. European Columbine. Very similar to A. Canadensis, but with spurs shorter and more curved, and the stamens less exserted; flowers white, blue, or purple, and often double. Common in cultivation.

\section{DELPHINIUIM.}

Annual or perennial herbs ; stem erect, simple, or branched; leaves alternate, petioled, palmately divided; flowers in terminal racemes or panicles, showy ; sepals 5, colored, irregular, the upper one prolonged into a spur; petals 4 , unequal, the two upper ones with long spurs which are enclosed in the spur of the upper sepal, the other two short-stalked; pistils 1-5, ovaries many-seeded.

1. D. azureum Michx. Blue Larkspur. Perennial; stem usually simple, slender, downy, 1-2 ft. high; leaves 2-3 in. wide, 3-5-parted, the divisions cleft into 3-5 narrow, toothed, or entire lobes; flowers in a strict, many-flowered, terminal raceme, showy, blue, spur ascending, curved; lower petals bearded, 2-cleft; pods erect. April-June. On rich soil in open places.

2. D. Consolida L. Garden Larkspur. Annual; stem branching, 3-4 ft. high; leaves cut and divided into narrowly linear lobes; racemes loosely flowered; flowers blue; petals somewhat united; pistil single. June-September. Introduced and naturalized in many places. 


\section{ANEMONE.}

Perennial herbs, with naked stems bearing opposite or whorled and divided leaves which form an involucre below the flowers; sepals 4-20, petal-like, soon deciduous; petals none; stamens very numerous; achenia capitate, pointed, or tailed.

1. A. nemorosa L. Wood Anemone. Stem simple, from a slender rootstock, smooth or slightly pubescent, 4-6 in. high, bearing a single flower about $1 \mathrm{in}$. broad; leaves 3, long-petioled, trifoliate, the divisions ovate-lanceolate or wedge-shaped, toothed, lobed or parted, about as long as the peduncle; sepals $4-6$, oval, white or often purple-tinged on the outside; achenia 15-20, with a hooked beak. March-April. Common in open woods.

2. A. Caroliniana Walt. Carolina Anemone. Stem simple, from a roundish tuber, slightly pubescent, $6-12$ in. high, bearing a single flower about 1 in. broad; root leaves 2-3, long-petioled, ternate, the divisions cut or lobed; stem leaves sessile, ternate, the divisions cuneate; sepals 12-20, white; head of fruit becoming oblong; achenia woolly. March-April. In open woods.

3. A. Virginiana L. Virginia Anemone. Stems at first simple, but finally bearing several long peduncles which may be again forked, hairy or woolly, 2-3 ft. high; leaves of the first involucre 3, on long petioles, 3-parted, those of the secondary involucres 2 , the divisions toothed or lobed; root leaves 2-4, similar to those of the involucres; flower $\frac{2}{3}-\frac{3}{4}$ in. wide; sepals 5 , greenishwhite, oval, acute; achenia woolly, in an oblong head. JuneSeptember. In open woods and fields.

\section{HEPATICA.}

Perennial herbs, with flowers and fruit like those of Anemone, but with simple stems and with the 3-leaved involucre so close to the flowers as to resemble a calyx.

H. triloba Choix. Liver-leaf. Stem erect, hairy, 3-6 in. high; involucre of 3 ovate, entire, sessile leaves; radical leaves long-petioled, 3-lobed, lobes entire; sepals 6-9, blue, purplish or white; flowers about 1 in. wide; achenia several, ovate, pointed, hairy. February-March. In rich, shady woods. 


\section{SYNDESMON.}

Small, perennial herbs; leaves decompound, glabrous, those from the root long-petioled, those of the stem sessile; flowers in a terminal umbel, slender pediceled; sepals petaloid; petals none; pistils 4-15, stigmas sessile, truncate.

S. thalictroides (L.) Hoffm. Rue Anemoxe. Stem slender, 6-10 in. high, from a cluster of tuberous roots; radical leaves longpetioled, biternate, leaflets oval, cordate, 3-5-lobed; stem leaves 2-3-ternate, whorled, the long-stalked leaflets veiny, forming an involucre of 6-9 apparently simple leaves ; flowers $3-6$ in an umbel, $\frac{1}{2}-\frac{3}{4}$ in. wide ; sepals $6-10$, white. March-May. In rich woods.

\section{CLematis.}

Perennial herbs or slightly woody vines, usually climbing by the leaf stalks; leaves opposite, simple or compound; sepals 4, petal-like; petals very small or wanting; pistils numerous, tipped by the persistent styles which often become long and plumose in fruit.

1. C. crispa L. Marsh Clematis. Stem climbing, a little woody below, slightly pubescent above, $3-5 \mathrm{ft}$. high ; leaves pinnately compound; leaflets $5-7$, varying from lanceolate to ovate, thin, entire or 3-5 lobed; flowers showy, perfect, solitary, on long, axillary peduncles; sepals lanceolate, acuminate, thick, wavy on the

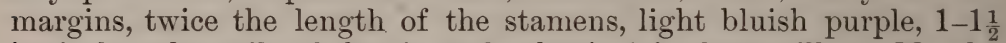
in. in length; tails of the ripened achenia 1 in. long, silky. MarchSeptember. Rich woods and river banks.

2. C. Virginiana L. Virgix's Bower. Stem somewhat woody, climbing over shrubs and trees; leaves ternately compound; leaflets ovate, acute, lobed, cordate at the base, 2-3 in. long, smooth ; flowers numerous, in axillary, panicled clusters, diœeious or polygamous; sepals obovate, hoary, spreading, white; tails of the achenia plumose, showy, 1 in. or more in length. June-July. River banks and meadows.

3. C. vioria L. Leather Flower. Stem climbing, nearly smooth, 6-10 ft. long; leaves usually pinnately compound, the lowest pair often ternate and the upper pair simple; leaflets usually $5-7$, oblong-ovate or oval, acute, firm, entire or lobed; calyx bellshaped, nodding; sepals ovate, acuminate with a short, recurved 
point, thick and leathery, reddish-purple, 1 in. long; tails of the achenia plumose, $1 \frac{1}{2}$ in. long, brownish. May-August. On river banks and rich soil.

\section{RANUNCULUS.}

Annual or perennial herbs ; leaves alternate, usually deeply lobed or parted; flowers axillary or in corymbs, white or yellow; sepals $3-5$; petals $3-5$, flat, with a small pit or scale inside at the narrowed base; stamens usually numerous; pistils few or several in a head; achenia flattened, pointed; mostly growing in wet soil.

1. R. Parviflorus L. Siall-flowered Buttercup. Annual ; stems erect, branched, downy, 6-12 in. high; leaves small, the lower orbicular, 3-lobed, sharply toothed, the upper 3-5-parted or entire; flowers very small; sepals reflexed; petals yellow, as long as the sepals; achenia margined, rough, with a recurved beak. April-May. Wet, waste places.

2. R. pusillus Poir. Low Spearwort. Perennial; stems several, erect or ascending, branched, glabrous, 6-15 in. high; leaves entire or slightly toothed, the lower round or cordate, long-petioled, the upper lanceolate or elliptical, nearly or quite sessile ; flowers very small, about $\frac{1}{6}$ in. wide, yellow; petals $1-5$, as long as the sepals; stamens $3-10$; achenia smooth, with a very short point. NarchApril. On muddy banks.

3. R. abortivus L. Small-flowered Crowfoot. Perennial ; stems glabrous, branching, 12-18 in. high ; root leaves roundcordate, crenate, petioled; stem leaves 3-5-parted, with wedge-shaped or linear divisions, sessile; flowers very small, pale yellow; sepals reflexed, longer than the petals; achenia in a globose head, smooth, with a short, recurved beak. March-April. Common on wet ground.

4. R. Recurvatus Poir. Hooked Crowfoot. Perennial; stem erect, hirsute, 1-2 ft. high ; leaves all nearly alike, petioled, 35 -lobed with the lobes wedge-shaped, cut or toothed at the apex; flowers small, pale yellow; petals minute, shorter than the reflexed sepals; achenia in a globular head, smooth, with a long and slender recurved beak. April-May. On low ground.

5. R. Penxsylyanicus L. Bristly Crowfoot. Perennial; stems rough-hairy, erect, 2-3 ft. high; leaves ternate, on long and very hairy petioles; leaflets long-stalked, 3-parted, the divisions sharply lobed or toothed; flowers small; petals yellow, shorter than the sepals; achenia flat, smooth, in oblong heads, beak broad and straight. May-June. On low ground; more common northward. 
6. R. nepens L. Creeping Crowfoot. Perennial; stems sometimes erect, 5-10 in. high, but usually forming long runners, smooth or háiry; leaves ternate or 3-parted, the divisions stalked, 3 -cleft or toothed; flowers bright yellow, 1 in. or more in width; petals much longer than the sepals; achenia in globose heads, smooth, broadly margined, beak broad, straight or slightly curved. Quite variable in size and habit of growth, often producing flowers on erect stems before runners are formed. March-May. On rich, moist soil.

7. R. Fascicularis Muhl. Tufted Buttercup. Perennial, from a cluster of thickened, fleshy roots ; stem erect, pubescent, 4$9 \mathrm{in.} \mathrm{high;} \mathrm{root} \mathrm{leaves} \mathrm{ternate,} \mathrm{but} \mathrm{the} \mathrm{middle} \mathrm{division} \mathrm{long-stalked}$ and 3-5-parted, making the leaf appear pinnate; stem leaves 3-5parted or lobed, the divisions oblong or elliptical; flowers bright yellow, 1 in. broad; petals obovate, much longer than the sepals; achenia smooth, scarcely margined, beak slender, straight or slightly curved. March-May. On rich soil and rocky hills; more common northward.

\section{THALICTRUM.}

Perennial herbs; leaves compound or decompound; flowers in umbels or panicles, polygamous or diœcious; sepals petallike or greenish; petals none; achenia ribbed.

T. Polygamum Muhl. Meadow Rue. Stems from fibrous roots, tall and coarse, nearly or quite smooth, 4-8 ft. tall; leaves decompound, those of the stem sessile, the others long-petioled; leaflets oval or oblong, often cordate, smooth or pubescent beneath, quite variable in size on the same plant; flowers small, in large panicles; sepals 4 or 5, white; achenia short stalked. May-August. Woods and meadows.

\section{P EONIA.}

Perennial, from thick, fleshy roots; stems shrubby or herbaceous; leaves much divided; flowers terminal, large and showy; sepals 5 , leaf-like and persistent; petals 5 or more; pistils $3-5$, ovaries surrounded by a disk.

P. officinalis L. Garden Pæony. Herbaceous; flowering stems 1-2 ft. high ; leaves ample; leaflets lance-ovate, cut or incised, smooth; flowers double, white or red; follicles 2, erect, many-seeded. Common in gardens. 


\section{BERBERIDACEA. BARBERRY FAMILY.}

Shrubs or herbs; leaves basal or alternate, simple or compound, exstipulate ; flowers solitary or racemed, perfect, regular, hypogynous; sepals and petals in 2 or more rows of 2-4 each, deciduous; stamens usually as many as the petals and opposite them; pistil 1; fruit berry-like or capsular, manyseeded.

\section{PODOPHYLLUM.}

Perennial ; stem simple, smooth, erect, 12-15 in. tall, bearing 2 leaves with a large white flower between them; sepals 6 , caducous ; petals $6-9$, obovate ; stamens twice as many as the petals; pistil 1, stigma large, flat, sessile; fruit berrylike, 1-celled, many-seeded.

P. peltatum L. May-apple. Rootstock rather large; leaves orbicular, peltate, 5-9-lobed and toothed, smooth, 9-12 in. wide; flowers 2 in. wide, on a peduncle 1-2 in. long; stamens prominent, anthers opening longitudinally ; fruit $1 \frac{1}{2}-2$ in. long, oval, fragrant, edible; each seed surrounded by a pulpy aril. April-May. In rich woods. The roots and leaves are drastic, and are used in medicine.

\section{MENISPERMACE $Æ$. MOONSEED FAMILY.}

Herbaceous or woody climbing or twining vines; leaves alternate, palmately veined, entire or lobed, exstipulate, on slender petioles; flowers small, polygamous or diøecious, in axillary racemes or panicles; sepals $4-12$; petals 6 or less; stamens usually 6 ; ovaries 3 or more, usually 6 , 1-ovuled; fruit a drupe.

\section{CEBATHA.}

Woody vines; stems slender and very hard; leaves rather thick, ovate, entire or 3-lobed; flowers in axillary racemes or panicles, diøecious or polygamous ; sepals 6 ; petals 6 ; fruit a drupe, with a rough, reniform seed. 
C. Carolina (L.) Britt. Carolina Moonseed. Stem twining, slightly pubescent above, 10-15 ft. long; leaves 3-lobed, acute, rigid; pistillate flowers in simple, and the staminate in compound racemes, greenish-white, small ; stamens 6 ; pistils $3-6$; drupe bright red, globular or compressed, as large as a small pea. June-August. Borders of woods and thickets.

\section{MENISPERMUM.}

Vines slender, climbing, much like Cebatha; leaves 3-7angled or lobed; flowers in axillary panicles, small, white; sepals and petals $4-8$; stamens $12-24$; pistils $2-4$, stigmas dilated; fruit a drupe.

M. Canadense L. Moonseed. Stem twining, 8-12 ft. high; leaves 5-7-angled, slightly cordate, peltate near the base; flowers greenish-white; pistils in the fertile flowers on a prominent, raised receptacle ; fruit globular, black ; seed crescent-shaped. June-July. River banks; more common northward.

\section{CALYCOCARPUM.}

Stem twining, pubescent, 20-50 ft. high; leaves palmately $3-5$-lobed ; flowers diœcious, in compound racemes ; sepals 6 ; petals none; stamens 12 ; pistils 3 , stigmas radiate, spreading; drupe oval, seed shaped like a shallow cup.

C. Lyoni Nutt. Cupseed. Stem climbing to the tops of trees; leaves round-cordate, 6-8 in. wide, lobes acuminate, veins prominent; flowers whitish, in large, axillary clusters; drupe $1 \mathrm{in.}$ long, greenish. June-July. River banks and moist woods.

\section{CALYCANTHACE E. STRAWBERRY-SHRUB FAMILY.}

Shrubs; leaves simple, opposite, entire, exstipulate; flowers perfect, solitary, terminal on lateral branches ; sepals and petals alike, numerous, united below, forming an obconical, fleshy cup; stamens numerous, short, the inner ones usually sterile; ovaries several, inserted on the inner surface of the cup-shaped receptacle, becoming 1-seeded achenia in fruit. 


\section{BUTNERIA.}

Shrubs, 4-8 ft. tall ; branches opposite ; leaves oval, pubescent beneath, short-petioled; both leaves and bark aromatic; sepals and petals many, in several rows, somewhat fleshy, indistinguishable; stamens numerous, short; pistils several, inserted on the inner side of the persistent calyx tube ; mature fruit pear-shaped, dry, enclosing the achenia.

B. Florida (L.) Kearney. Sweet-scented Shrub. A widespreading bush 4-8 ft. high; twigs pubescent; leaves oval or oblong, acute or acuminate, rough above, pubescent beneath, 2-3 in. long; flowers 1 in. wide, brownish-purple, very fragrant; sepals united below to form a cup on the inside of which the other parts of the flower are inserted, cup leafy-bracted on the outside. April-May. Banks of streams and rich hillsides; often cultivated.

\section{LAURACE $\mathbb{E}$. LAUREL FAMILY.}

Aromatic trees or shrubs; leaves simple, alternate, exstipulate, dotted; flowers small, perfect or imperfect, in small, axillary clusters; calyx of 4-6 colored sepals in 2 rows; petals none; stamens 9-12, inserted on the calyx in 3-4 rows, distinct, usually some of them imperfect; ovary superior, style single, ovule solitary; fruit a drupe or berry. Among the foreign plants belonging to this family are the Cinnamon (Cinnamomum Zeylandicum) and Cassia (C. cassia) from Ceylon, and Camphor ( $C$. camphora) from China and India. The latter is often planted for ornament in the Gulf States.

\section{PERSEA.}

Small trees or shrubs; leaves evergreen, coriaceous, entire, petiolate; flowers perfect, in axillary panicles; calyx 6parted, persistent; stamens 12 , in 4 rows, the inner sterile, anthers 4-celled; stigma disk-like; fruit an ovoid drupe.

P. Borbonica (L.) Spreng. Red Bay. A shrub or small tree with dark brown bark; leaves lanceolate to oblong-ovate, dark green 
and smooth above, paler and pubescent beneath, petioles $\frac{1}{2}-1 \mathrm{in}$. long; peduncles about as long as the petioles; calyx pubescent, persistent, its lobes unequal; drupes dark blue, on thick, red pedicels. June-July. In moist woodlands.

\section{SASSAFRAS.}

A tree with rough, yellowish bark and a spreading top; leaves deciduous, entire or 2-3-lobed; flowers diøecious, involucrate, at the end of the twigs of the previous season; calyx 6-parted, persistent in the pistillate flowers; stamens 9 , in 3 rows; pistillate flowers with $4-6$ abortive stamens and a single ovary; fruit a drupe.

S. Sassafras (L.) Karst. Sassafras. A tree, usually small and slender, but sometimes with a trunk $3 \mathrm{ft}$. in diameter and 125 ft. high; leaves oval, entire, mitten-shaped or 3-lobed, pubescent when young but becoming smooth with age, dark green above, paler below, petiolate; racemes several in a cluster, peduncled; flowers yellow; stamens about as long as the sepals ; fruit dark blue, ovoid, on thickened, red pedicels. All parts of the tree aromatic; trees producing pistillate flowers rare. April-May. Common. The wood is valuable for cabinet making, and an aromatic oil is extracted from the bark.

\section{BENZOIN.}

Shrubs ; leaves deciduous, entire; flowers in lateral, sessile clusters, appearing before the leaves, diøcious or polygamous; involucre of 4 scales; stamens 9 in the staminate flowers, filaments slender; pistillate flowers with 12-15 abortive stamens and a single globose ovary with a short style.

B. Benzoin (L.) Coult. Spice-Bush. A shrub 5-15 ft. high, with smooth bark and slender twigs; leaves oblong-obovate, acute at the base, pale and pubescent beneath, becoming smooth when old; petioles short; flowers about as long as the pedicels, yellow, very fragrant; ovary about as long as the style; fruit an obovoid, red drupe about $\frac{1}{3}$ in. long, on a slender pedicel. February-March. Banks of streams and damp woods. Twigs and leaves quite aromatic. 


\section{PAPAVERACEA. POPPY FAMILY.}

Herbs, with milky or colored juice; leaves alternate, or rarely a few of the upper ones opposite, exstipulate; flowers perfect, solitary or in clusters; sepals $2-3$, caducous; petals 4-12, deciduous, sometimes irregular; stamens few or many, hypogynous, filaments filiform; ovaries 1 or many, usually 1-celled, many-seeded; fruit a capsule.

\section{PAPAVER.}

Annual or perennial herbs, with milky juice; stem erect, smooth or hispid, branching above; leaves more or less lobed or dissected; flower buds nodding, flowers showy; sepals commonly 2 ; petals 4-6; stamens many; stigma disk-like, ovules many, borne on inwardly projecting placentæ.

1. P. somniferum L. Opium Poppy. Annual; stem erect, branched above, smooth and glaucous, 2-3 ft. high; leaves oblong, irregularly lobed or cut, sessile, clasping; flowers nearly white with a purple center, large and showy, on long peduncles; capsule globose, seeds minutely pitted. May-August. About old gardens and waste places. Cultivated in southern Asia, where the juice of the capsules is dried to make opium.

2. P. dubium L. Corn Poppy. Annual; stem slender, branching, 1-2 ft. tall ; leaves pinnatifid, the lower petioled, the upper sessile; flowers large and showy, usually red; capsule long-obovate, glabrous. May-July. In cultivated ground. Both the species named are often cultivated in gardens, and produce double flowers.

\section{SANGUINARIA.}

Perennial; rhizome thick, horizontal, joints and scars of previous growths persistent several years; juice orange colored; leaves on long petioles, reniform; scape 1-flowered; sepals 2 , fugacious; petals $8-12$; ovary 1 , stigmas 2 ; capsule oblong, seeds crested.

S. Canadensis L. Bloodroot. Leaves and scape glaucous; leaves palmately 5-9-lobed, lobes rounded or toothed; scapes naked, 
nearly as long as the petioles; flowers white, 1 in. or more wide; petals oblong or obovate, quickly deciduous; capsule 1-celled, 2valved, the valves separating from the persistent placentæ at maturity. March-April. In rich, shady woods.

\section{CAPNOIDES.}

Erect herbs; juice reddish-brown; leaves much dissected or decompound; flowers in racemes which are terminal or opposite the leaves; sepals 2 , small ; corolla irregular, petals 4 , one of the outer spurred or saccate at the base, the 2 inner narrower and keeled on the back; stamens 6, three opposite each of the outer petals ; stigma 2-lobed, persistent, placentæ 2.

C. micranthum (Engelm.) Britt. Dutchuan's Breeches. Stem slender, diffuse, glabrous; leaves finely dissected, the divisions nearly linear; flowers pale yellow; inner petals mucronate, the keel usually entire; fruit a linear, torulose, short-pediceled pod. February-March. In rich woods.

\section{CRUCIFER E. MUSTARD FAMILY.}

Herbs, with watery, pungent juice; leaves alternate, exstipulate; flowers perfect, regular, hypogynous, in racemes or panicles with bractless pedicels; sepals 4, usually erect and appressed to the corolla, deciduous; petals 4, with spreading limbs forming a cross, rarely wanting; stamens usually 6 , two of them shorter than the others and opposite the inner sepals; pistil 1, compound, style usually persistent, ovary 2-celled by a rnembranous partition; fruit a silique or silicle. The family furnishes a number of food plants, among which are the cabbage, cauliflower, brussels sprouts, kohl rabi, and kale, all of which are forms of the European Brassica oleracea; the Turnip (B. campestris) and the Horse Radish (Roripa Armoracia) which does not produce seed in this country. Most of the native plants belonging to the family are insignificant or troublesome weeds. 
Pod many times longer than broad.

Flowers yellow

Flowers white or colored.

Seeds globose

Seeds flat

Pod short.

\section{Flat, orbicular.}

Flattened contrary to the partition

Flattened parallel to the partition . Flat, cuneiform

Terete, globose or oblong

\section{Sophia.}

VII. Hesperis.

III. Cardamine.

\section{LEPIDIUM.}

Annual; stem erect, or sometimes diffuse; leaves entire, toothed or pinnately divided; flowers in a terminal raceme, small, white; petals short, sometimes wanting; stamens 2 , 4 , or 6 ; silicle rounded or obcordate, flattened contrary to the partition.

L. Virginicum L. Peppergrass. Stem erect, smooth, much branched, 1-2 ft. high; lower leaves obovate in outline, pinnatifid with dentate lobes; upper leaves lanceolate, dentate, slightly pubescent; flowers on slender pedicels, petals often wanting in the later ones ; stamens 2 ; silicle orbicular. March-July. A weed growing in waste places.

\section{RORIPA.}

Annual or biennial; stems erect or diffuse, often widely branching; leaves simple, pinnately lobed; flowers small, white or yellow; sepals spreading; stamens 1-6; silique short and broad or nearly linear; seeds numerous, in 2 rows in each cell.

1. R. Nasturtium (L.) Rusby. Watercress. Aquatic herbs; stems glabrous, diffuse, rooting at the joints; leaves with 3-9 rounded, pinnate lobes, the terminal lobe much the largest; racemes elongating in fruit; petals white, twice the length of the sepals; pod linear, $\frac{1}{2}-\frac{3}{4}$ in. long, on slender, spreading pedicels. MarchNovember. In ditches and slow streams. Often used for salad.

2. R. Palustris (L.) Bess. Yellow Watercress. Annual or biennial; stem erect, branched, slightly pubescent; leaves irregu- 
larly lyrate-pinnatifid, the lower petioled, the upper sessile; flowers small; petals yellow; pods linear, spreading, longer than the pedicels. March-April. In wet places.

\section{CARDAMINE.}

Annual or perennial; rootstock often scaly or bulbiferous; stem erect or ascending, usually glabrous; leaves more or less divided; flowers in terminal racemes, white or purple; petals rather large; stamens 6 ; fruit an elongated silique, seeds several in a single row in each cell.

C. Bulbosa (Schreb.) B. S. P. Bulbous Cress. Perennial; root tuberous; stem simple, erect, smooth, without runners, 9-18 in. tall; lower leaves long-petioled, ovate, orbicular or cordate, often angled or toothed, the upper short-petioled or sessile, lanceolate or oblong, toothed or entire; pericels $\frac{1}{2}-1$ in. long; petals white, $\frac{1}{4}-\frac{1}{3}$ in. long; silique erect, linear-lanceolate, tipped by the persistent style; seeds round-oval. April-May. Cool, wet places.

C. hirsuta L. Hairy Bittercress. Annual; stem slender, erect, simple or with a few slender branches, more or less pubescent, $6-15$ in. tall; leaves mostly in a cluster at the base of the stem, pinnately divided, the terminal lobe orbicular, the lateral lobes narrower, somewhat hirsute above, stem leaves nearly linear; flowers small; petals white, longer than the sepals; stamens 4 ; pods linear, erect on erect pedicels, about 1 in. long; seeds oval. March-April. In waste places.

\section{BURSA.}

Annual; stem erect; pubescence of branched hairs ; racemes terminal, becoming elongated in fruit; flowers small, white; silicle obcordate or triangular, flattened contrary to the partition, shorter than the spreading pedicel.

B. Bursa-pastoris (L.) Britt. Shepherd's Purse. Root long and straight; stem branching above, pubescent below, smooth above ; lower leaves forming a rosette at the base of the stem, irregularly lobed or pinnatifid, stem leaves lanceolate, clasping, toothed or entire; sepals pubescent, about half as long as the petals; pod triangular, emarginate or cordate at the apex; seeds several in each cell. February-July. A common weed. 


\section{SOPHIA.}

Annual or perennial; stem erect, slender, branching, pubescent; leaves twice pinnatifid or dissected; flowers in terminal racemes, small, yellow, racemes becoming elongated at maturity; silique linear or linear-oblong, terete or angled, seeds oval, in 1 or 2 rows in each cell.

S. Pinnata (Walt.) Britt. Hedge Mustard. Annual; stem erect, branched, pale canescent or hoary, 12-24 in. tall; leaves oblong, twice pinnatifid into narrow, toothed segments; pedicels slender, spreading, about $\frac{1}{2}$ in. long; flowers small, pale; silique horizontal or ascending, about half the length of the pedicel, seeds in 2 rows in each cell. March-April. Common in waste places.

\section{KONIGA.}

Perennial, though usually growing as an annual; stems branching, diffuse, branches slender; leaves small, entire, pubescent with forked hairs ; flowers small, white, in numerous terminal racemes; petals obovate, entire, twice as long as the sepals; filaments enlarged below; silicle orbicular, compressed, seeds 1 in each cell.

K. maritima (L.) R. Rr. Sweet Alyssum. Stem weak, diffuse, ascending, minutely pubescent; lower leaves narrowed into a petiole, the upper sessile; racemes erect, many-flowered; flowers fragrant, pedicels ascending; silicle often pointed. Common in cultivation and often spontaneous.

\section{HESPERIS.}

Biennial or perennial; stems erect, branched, pubescent with forked hairs; leaves seldom divided; flowers showy, in terminal racemes; stigma 2-lobed; fruit a long, cylindrical silique.

H. matronalis L. Dame's Violet. Suem branched above, 2-3 ft. high; leaves lanceolate or ovate-lanceolate, acute or acuminate, denticulate with minute teeth, pubescent on both sides, the lower long-petioled and sometimes divided, the upper short-petioled or sessile; flowers white or colored, fragrant, $\frac{3}{4}-1$ in. wide; petals 
spreading, much longer than the erect sepals; silique slender, nodulose, 2-4 in. long; seeds 1 row in each çell. March-July. Escaped from cultivation.

\section{CAPPARIDACE $Æ$. CAPER FAMILY.}

Herbs, shrubs or trees, with an acrid, watery juice; leaves usually alternate, simple or palmately compound; stipules spiny or wanting; flowers often irregular, usually perfect; sepals 4-8; petals 4 or wanting; stamens 6 or more; style usually short, receptacle often elongated; fruit a pod or berry.

\section{CLEOME.}

Mostly annual herbs; stems branched; leaves petioled, simple or 3-7-foliate, leaflets entire or serrate; flowers in bracted racemes; sepals 4 , often persistent; petals 4 , longclawed, nearly equal, entire; stamens 6, filaments filiform, usually much exserted but sometimes 1-3 much shorter than the others, inserted on the short receptacle; ovary on a short stipe with a small gland at its base; fruit a slender capsule on an elongated stipe.

C. spinosa L. Spider Flower. Annual; stem erect, branched above; leaves alteruate, large, the lower long-petioled, the upper short-petioled or sessile, 5-7-foliate, leaflets lanceolate, acute, serrulate; stipules spiny; flowers numerous, showy, white or purplish, in long, bracted racemes, lower bracts trifoliate, the upper simple, cordate-ovate; pedicels long; petals obovate, long-clawed; capsule smooth, linear, shorter than the stipe which is often $4-6$ in. in length. May-August. Common in waste places.

\section{RESEDACE Æ. MIGNONETTE FAMILY.}

Annual; stem diffuse, widely branched; leaves sessile, entire or lobed, smooth; flowers in spikes or racemes, bracted, irregular, fragrant; calyx 4-7-parted, inequilateral; petals 4-7, entire or cleft; stamens 8-30, inserted on the hypogynous, one-sided disk; ovary sessile, 3-6-lobed, stigmas 3-6, ovules many. 


\section{RESEDA.}

Annual; stems diffuse, widely branched; leaves sessile, entire or lobed, smooth; flowers in close racemes or spikes; petals 4-7, toothed or cleft; stamens 8-30, inserted at one side of the flower; capsule 3-6-lobed, opening at the top before the seeds mature.

R. odorata L. Mignonette. Stem widely diffuse, 6-12 in. high, smooth; leaves cuneiform, entire or 3-lobed; flowers small, greenish-yellow, very fragrant; petals deeply 7-13-cleft. AprilJuly. Often cultivated. From Egypt.

\section{SARRACENIACE E. PITCHER-PLANT FAMILY.}

Perennial, acaulescent, marsh herbs; leaves tubular or trumpet-shaped; flowers single, nodding, on a naked or bracted scape; sepals 4-5, colored, persistent; petals 5, deciduous, or sometimes wanting; stamens numerous; pistil compound, 5-celled, many-ovuled, style terminal, nearly as broad as the flower, peltate.

\section{SARRACENIA.}

Rootstock short, horizontal; scape naked; leaves trumpetshaped with a ventral wing extending nearly to the base and a broad lamina at the apex; tube hairy within, with downward-pointing, stiff hairs; calyx 3-bracted; petals obovate, drooping or incurved; style umbrella-shaped, 5-angled; stigmas at the hooked angles of the style; capsule globose, rough. [The tubular leaves usually contain more or less water and dead insects, the latter having been attracted by a honey-like secretion near the opening. For a full account of the structure and peculiar action of the leaves, see Goodale's Physiological Botany, pp. 347-353.]

1. S. purpurea L. Side-sadde Flower. Leaves ascending, curved, broadly winged, purple-veined, 4-8 in. long; lamina erect, round-cordate, hairy on the inner side; scapes $12-18$ in. tall ; flower deep purple, about 2 in. broad; style yellowish. April-May. Mossy swamps. 
2. S. Psitticina Michx. Small Pitcher-Plant. Leaves in a spreading rosette, 3-5 in. long; tube slender, broadly winged, densely hirsute within; lamina strongly incurved over the narrow opening, marked with purple and white; flower purple, about $1 \frac{1}{2}$ in. broad. April-May. Pine-barren swamps.

3. S. Flava L. Trumpet-leaf. Leaves large, erect, glabrous, yellowish, narrowly winged; $2 \mathrm{ft}$. high; lamina erect, orbicular, slender pointed, pubescent within, often reticulated with purple veins; scape as long as the leaves; flowers yellowish; petals 2-3 in. long, finally drooping. April-May. Wet pine barrens.

4. S. variolaris Michx. Spotted Trumpet-leaf. Leaves erect, broadly or sometimes narrowly winged, spotted with white near the yellowish summit; lamina ovate, arching over the open mouth of the tube, hairy, and reticulated with purple veins within; flowers yellow; petals 1 in. or more in length. April-May. Low pine barrens.

\section{DROSERACEAE. SUNDEW FAMILY.}

Acaulescent, marsh herbs; leaves tufted, glandular-pubescent, circinate in bud; flowers racemose, on a slender, naked scape; calyx of 4-5 distinct or slightly united, persistent sepals; petals 5, distinct or slightly united at the base, hypogynous, withering; stamens $5-15$, distinct; ovary free, 1-celled, many-ovuled, styles $1-5$, simple or cleft.

\section{DROSERA.}

Leaves thickly set with glandular hairs, making them appear as if covered with dew; calyx free from the ovary, deeply 4-5-parted; petals usually 5 ; stamens 5 ; styles $3-5$, deeply 2-parted or fimbriate; capsule 3 -valved, many-seeded.

1. D. Filiformis Raf. Thread-leaved Sundew. Rhizome thick, creeping; leaves erect, narrowly linear or filiform, smooth at the base, very viscid-pubescent above, 10-15 in. long; scape smooth, many-flowered, 12-18 in. high ; flowers bright purple, $1 \mathrm{in.}$ wide; petals obovate, much longer than the hairy sepals; seeds oblong, minutely dotted. April-May. Low pine barrens.

2. D. rotundifolia L. Round-Leaved Sundew. Rhizome none ; leaves orbicular, contracted below into a hairy petiole $1 \frac{1}{2}-2$ in. long; scape smooth, erect, $6-10$-flowered ; flowers white ; seeds covered with a loose, membranaceous coat. May-June. Mossy swamps. 
3. D. Brevifolia Pursh. Short-leaved Sundew. Rhizome none; leaves short, wedge-shaped, glandular-pubescent; scape 3-6flowered, 3-6 in. high; flowers white, $\frac{1}{2}$ in. wide; seeds ovoid, minutely glandular. March-April. Low, sandy pine barrens.

\section{CRASSULACE王. ORPINE FAMILY.}

Herbs, usually succulent; leaves alternate or opposite, simple, exstipulate; flowers perfect, regular, cymose or rarely solitary; calyx 4-5-cleft, persistent; petals as many as the sepals, often slightly united at the base, usually persistent, sometimes wanting; stamens as many or twice as many as the petals; carpels as many as the petals, distinct, or united below ; fruit a membranaceous, 1-celled, many-seeded follicle.

\section{PENTHORUM.}

Perennial; stem erect, branched above, only slightly succulent; leaves alternate, serrate, sessile; flowers in cymes; sepals 5 ; petals 5 or wanting; stamens 10 ; carpels 5 , united about half their length, many-seeded.

P. Sedoides L. Ditch Stonecrop. Stem terete below, branching and angled above, glabrous, 1-2 ft. high; leaves lanceolate or elliptical, acuminate, finely serrate; flowers yellowish, short-pediceled, on one side of the revolute branches of the cyme; sepals triangular, acute, shorter than the capsule; petals often wanting. June-September. Common in ditches and muddy places.

\section{SAXIFRAGACE 2 . SAXIFRAGE FAMILY.}

Herbs, shrubs, vines or trees; leaves alternate, opposite or basal; stipules adnate to the petioles or wanting; flowers perfect or imperfect, solitary or variously clustered; calyx of 4-5 more or less united sepals, free or partially adherent to the ovary; petals as many as the sepals or sometimes wanting; stamens as many or twice as many as the sepals, inserted on the calyx; ovaries 1-4, commonly united below and often separated above; fruit a capsule or berry. 


\section{PARNASSIA.}

Perennial herbs; basal leaves long-petioled, entire; the slender scape bearing a single, sessile leaf; flowers large, solitary; sepals 5 , persistent, united at the base; petals 5 , spreading; fertile stamens 5, alternate with the petals; abortive stamens numerous, in clusters at the base of each petal; ovary 1-celled, with 3-4 parietal placentæ; seeds numerous.

P. Caroliniana Michx. Grass-of-Parnassus. Basal leaves ovate or cordate, rounded at the apex, often decurrent into the petioles; cauline leaf ovate, clasping; scape 12-18 in. high ; flower $1-1 \frac{1}{2}$ in. broad; sepals ovate; petals oval, white with greenish veins ; abortive stamens 3 in each set, distinct, much longer than the recurved fertile ones; capsule $\frac{1}{3}-\frac{1}{2}$ in. long. June-October. On damp soil.

\section{ITEA.}

Shrubs or small trees; leaves alternate, simple, deciduous, exstipulate; flowers white, in slepder, drooping, terminal racemes; calyx campanulate, 5 -cleft; petals 5 , inflexed at the apex; stamens 5 , shorter than the petals; ovary 2-celled, many-seeded.

I. Virginica L. Itea. A shrub, 4-10 ft. high; twigs pubescent; leaves oblong or oval, short-petioled, acute or acuminate at the apex, sharply serrate, glabrous or somewhat pubescent beneath ; racemes slender, dense, 3-6 in. long; flowers short-pediceled, white, $\frac{1}{3}-\frac{1}{2}$ in. wide; petals narrowly lanceolate, erect or spreading; capsule 2-grooved, pubescent, tipped by the persistent, 2-parted style. AprilJune. Common in wet places.

\section{HYDRANGEA.}

Erect shrubs; leaves simple, opposite, petioled, exstipulate; flowers in terminal corymbs, marginal flowers often sterile with enlarged and showy calyx lobes, fertile flowers small; calyx tube hemispherical, 8-10-ribbed, coherent with the ovary, limb 4-5-cleft; petals 4-5; stamens 8-10; capsule 2-4-celled, crowned with the divergent styles, many-seeded.

1. H. radiata Walt. Downy Hydrangea. Shrub, 6-8 ft. tall; leaves ovate, often cordate at the base, acute or acuminate at 
the apex, serrate, smooth above, densely white-tomentose beneath; cymes flat-topped; sterile flowers few, but large and conspicuous. May-June. On rich soil, river banks, etc.

2. H. Quercifolia Bart. Oak-leafed Hydrangea. Shrub, 3-6 ft. tall ; leaves oval, usually 5-lobed, serrate, tomentose; cymes clustered in a dense, oblong panicle; sterile flowers large and numerous, whitish, becoming purple. May-June. On shady banks.

3. H. hortensis L. Garden Hydrangea. Shrub 1-3 ft. tall; leaves elliptical, acute at each end, serrate-dentate, smooth, strongly veined; cymes convex above; flowers nearly all sterile, white, blue, or pink. May-July. Common in gardens.

\section{PHILADELPHUS.}

Shrubs; leaves simple, opposite, 3-5-ribbed, petioled, exstipulate; flowers solitary or cymose, large, white; calyx tube turbinate, cohering with the ovary, the limb 4-5-parted, persistent; petals 4-5, rounded or obovate; stamens 20-40, shorter than the petals; ovary 3-5-celled, many-seeded, styles $3-5$, more or less united.

1. P. grandiflorus Willd. Large-Flowered Syringa. Shrub, 6-10 ft. high; branches pubescent; leaves ovate or ovateoblong, acuminate, sharply serrate, pubescent, 3-ribbed; flowers solitary or 2-3 together, white, $1 \frac{1}{2}-2$ in. broad, not fragrant; calyx lobes ovate, acuminate, about twice as long as the tube. AprilMay. On low ground.

2. P. Coronarius I. Garden Syringa. Shrub, $8-10 \mathrm{ft}$. high; leaves oval or ovate, obtuse at the base, acute at the apex, remotely denticulate, smooth above, pubescent beneath; flowers in terminal racemes, creamy white, $1-1 \frac{1}{2}$ in. wide, very fragrant; calyx lobes ovate, acute, longer than the tube. May-June. Common in cultivation.

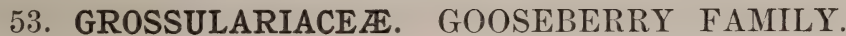

Shrubs; branches smooth or prickly; leaves alternate, often fascicled, palmately veined and lobed; stipules wanting; flowers axillary, racemose or clustered; calyx tube adherent to the ovary, limb 5-parted, persistent; petals 5, small; stamens 5; ovary 1-celled, with 2 parietal placentæ; fruit a many-seeded berry. 


\section{RIBES.}

Characters of the family.

1. R. Cynosbati L. Wild Gooseberry. A spreading bush 2-4 ft. tall, with the older stems prickly and the younger nearly smooth; leaves nearly circular, slightly cordate, 3-5-lobed, the lobes crenate or incised, somewhat pubescent, petiole long and slender; peduncles 2-3-flowered, flowers greenish; stamens and style not longer than the calyx tube; berry covered with prickles. AprilJune. In rocky woods. More common northward.

2. R. rotundfolidm Michx. Sмоoth Gooseberry. A straggling shrub 3-4 ft. high, the branches often smooth; leaves roundish, the base not cordate and often acute, $3-5$-lobed and incised, pubescent beneath; peduncles 1-2-flowered, flowers greenish-purple; stamens longer than the calyx tube; berry small, smooth. April-June. In rocky woods.

3. R. Rubrum I. Red Currant. A shrub 2-4 ft. high, branches smooth; leaves orbicular to reniform, 3-5-lobed, the lobes sharply dentate, pubescent beneath when young; petioles slender, 1-3 in. long; flowers many, in pendulous racemes, greenish, pedicels bracted; stamens short; fruit smooth, red or nearly white. AprilMay. Native in the northern states and often cultivated.

\section{HAMAMELIDACE E. WITCH-HAZEL FAMILY.}

Trees or shrubs, with alternate, petioled, simple leaves and deciduous stipules; flowers perfect, polygamous or monœcious, variously clustered; calyx tube coherent with the base of the ovary; petals 4-5, long and showy, or entirely wanting; stamens twice as many as the petals with the alternate ones sterile, or numerous and perfect; styles 2 ; fruit a woody, 2-celled capsule opening at the summit, seeds bony, 1 or more in each cell.

\section{HAMAMELIS.}

Large shrubs; leaves short-petioled; flowers yellow, lateral, clustered; calyx 2-3-bracted, 4-parted; petals 4, elongated and linear, sometimes wanting in the staminate flowers; stamens 8 , the alternate ones sterile; styles 2 , ovules 2 ; seeds large, bony, oblong, shiny. 
H. Virginica L. Witch Hazel. A shrub sometimes reaching $20 \mathrm{ft}$. in height; leaves obovate or oval, acute or obtuse at the apex, cordate or oblique at the base, dentate, stellate-pubescent; flowers in axillary clusters, bright yellow, nearly sessile ; calyx lobes spreading, pubescent; petals $\frac{1}{2}-\frac{3}{4}$ in. long; capsule woody, beaked by the 2 persistent styles, very pubescent. October and November, the fruit requiring nearly a year to mature. Common in low woods and on margins of swamps.

\section{LIQUIDAMBAR.}

Trees, the limbs usually corky-winged; flowers monœcious, the staminate heads sessile, spiked or racemose, the pistillate usually single; calyx and corolla wanting; stamens very numerous, filaments short; ovary partly inferior, styles 2 , ovules several in each cell; the 2 -beaked capsules united into a close head, seeds wing-angled.

L. Styraciflua L. Sweet-Gum. Large trees; leaves roundish, stellate-lobed, finely serrate, smooth above, often pubescent below; spikes bearing the staminate flowers soon deciduous; the pistillate heads long-peduncled, soon drooping, mature heads spiny, $1-1 \frac{1}{2}$ in. in diameter. March-April. A common tree with a resinous juice which hardens into a fragrant gum.

\section{PLATANACEZ. SYCAMORE FAMILY.}

Trees; with simple, alternate, petioled, stipulate leaves, the bases of the petioles covering the buds; flowers monøecious, in axillary, long-peduncled, globose heads; calyx and corolla very inconspicuous, each consisting of 3-8 minute scales, or wanting; stamens as many as the sepals and opposite them; pistils several, obconical, hairy at the base, styles long; capsules 1-seeded.

\section{PLATANUS.}

Characters of the family.

P. occidentalis L. Sycamore, Buttonwood. A large tree, bark light-colored, smooth, exfoliating in large, thin plates; leaves large, round-cordate, angularly lobed and toothed, densely whitewoolly when young, becoming smooth with age; stipules large, 
toothed; fruit in a globular, pendulous head which remains on the tree through the winter, dropping the seeds very slowly. MarchApril. Common on river banks and in swampy woods.

\section{ROSACE E. ROSE FAMILY.}

Herbs, shrubs or trees; leaves alternate, simple or compound, stipulate; flowers perfect; sepals $3-8$, usually 5, more or less united; petals as many as the sepals or none; stamens numerous and, with the petals, inserted on the calyx tube; pistils 1, few or numerous, often united with the calyx tube; ovary 1-2- or several-seeded; fruit of many forms, but more often an achene, follicle, or aggregation of drupes.

Fruit a follicle.

Follicles inflated

I. Opulaster.

Follicles not inflated.

Flowers regular

Flowers irregular .

Fruit an aggregation of drupes . . . .

II. Spirea.

III. Porteranthus.

Fruit an achene.

Achenes many.

Receptacles fleshy, flowers white .

V. Fragaria.

Receptacles fleshy, flowers yellow

VI. Duchesnea.

Receptacles dry, styles deciduous

VII. Potentilla.

Receptacles dry, styles persistent

VIII. Geum.

Achenes 1 or 2 .

IX. Agrimonia.

Achenes enclosed by the fleshy calyx tube.

X. Rosa.

\section{OPULASTER.}

Shrubs; leaves simple, palmately veined and lobed, petioled; flowers white, in terminal corymbs; calyx spreading, 5 -lobed; petals 5 ; stamens numerous; pistils $1-5$, short-stipitate, stigma terminal; ovaries becoming inflated at maturity, $2-4$ seeded, dehiscent.

O. opulifolius (L.) Kuntze. Ninfebark. A spreading shrub $3-6 \mathrm{ft}$. high, the old bark separating into thin strips; leaves petioled, broadly ovate or rounded, often cordate, 3-lobed, the lobes doubly 
crenate-serrate; stipules deciduous; corymbs terminal, peduncled, nearly globose, pubescent, many-flowered; pedicels and calyx nearly glabrous; follicles $3-5$, much longer than the calyx, smooth and shining, obliquely tipped by the persistent style. April-May. Banks of streams.

\section{SPIREA.}

Shrubs with simple leaves; flowers perfect, in terminal or axillary racemes or panicles; calyx 5-cleft, persistent; petals 5 ; stamens numerous; pistils usually 5 , free from the calyx and alternate with its lobes; follicles not inflated, 2-severalseeded.

1. S. Salicifolia L. Willow-leafed Spirea. Shrubs $2-5 \mathrm{ft}$. high, branches smooth; leaves lanceolate to oblong-ovate, smooth or nearly so, sharply serrate, base usually cuneate, pale beneath ; stipules deciduous; flowers white or pink, panicle dense-flowered; follicles smooth. May-July. On low ground.

2. S. Reevesiana Gard. Bridal Wreath. Shrubs 2-4 ft. tall; branches long, slender and spreading; leaves lanceolate, serrate, sometimes 3-lobed or pinnatifid, glaucous beneath; flowers white or pinkish, in axillary racemes or corymbs, often forming long wreaths; follicles smooth. May-June. Introduced from Europe.

3. S. томentosa L. Hardhack. Erect shrubs; stems tomentose, usually simple; leaves simple, ovate or oblong, serrate, densely tomentose below, smooth and dark green above; flowers small, pink or purple, in a close panicle; follicles 5, tomentose, several-seeded. May-June. On low ground.

\section{PORTERANTHUS.}

Perennial herbs; leaves nearly sessile, 3 -foliate or 3-parted; flowers white or rose-colored, in loose corymbs ; calyx tubularcampanulate, 5-toothed; petals 5, unequal; stamens 10-20; follicles 5 , included in the calyx, 2-4-seeded.

P. stipulatus (Muhl.) Britt. American Ipecac. Stem 2-3 ft. tall, branches few; leaves lanceolate, coarsely serrate or the lower incisely lobed; stipules leaf-like, ovate, serrate; coryınbs few-flowered, flowers pink; petals linear-lanceolate, $\frac{1}{2}$ in. long; follicles nearly smooth. May-June. On hills in rich woods. 


\section{RUBUS.}

Shrubs; stems usually prickly; leaves ample, 3-5-lobed or compound; calyx bractless, concave or nearly flat, 5-parted; petals 5 ; stamens numerous; pistils numerous, forming small drupelets which are inserted on an elongated receptacle to form an aggregated fruit, style deciduous.

1. R. occidentalis L. Black Raspberry. Stems long and slender, often recurved and rooting at the tips, armed with weak, hooked prickles; leaves petioled, 3-5-foliate, leaflets ovate, coarsely serrate, white-downy below; flowers white, in compact terminal corymbs; pedicels erect or ascending; fruit black, hemispherical, separating easily from the receptacle. April-May. Common on borders of woods northward, widely cultivated.

2. R. strigosus Michx. Red Raspberry. Stems widely branching, biennial, not rooting at the tips, armed with weak bristles and with a few hooked prickles; leaves petioled, 3-5-foliate; leaflets ovate, acuminate, sharply serrate and sometimes lobed, pubescent beneath; flowers in terminal and axillary racemes and panicles, pedicels drooping; fruit hemispherical or conical, red, separating easily from the receptacle. April-May. Common on mountains and burned clearings in the northern section and widely cultivated.

3. R. ARgutus Bailey. Blackberry. Stem shrubby, erect or bending, 4-10 ft. high, glandular-pubescent above and with stout, hooked prickles below; leaves petioled, 3-7-foliate, leaflets ovate, acute, irregularly serrate, smooth or soft hairy; flowers in terminal, bracted panicles; petals white, obovate, much longer than the acuminate sepals ; fruit large, black, oblong, adhering to the receptacle. March-May. Common in thickets.

4. R. Cuneifolius Pursh. Sand Blackberry. Stem shrubby, erect or diffuse, 2-3 ft. high; prickles straight or recurved; leaves petioled, 3-5-foliate, leaflets obovate, serrate towards the apex, cuneate towards the base, rough above, white tomentose beneath; racemes mainly terminal, few-flowered; petals white, longer than the sepals; fruit ovoid, black, adhering to the receptacle, smaller than the preceding. March-April. Common in old fields.

5. R. Trivialis Michx. Dewberry. Stem trailing or prostrate, often several feet in length, armed with small, straight or recurved prickles, and often thickly set with bristles; leaves petioled, mostly 3 -foliate; leaflets ovate-lanceolate or oval, acute, sharply serrate, smooth; flowering branches commonly erect, few-flowered, flowers large, white; fruit black, adhering to the receptacle. March-April. Common on dry, sandy soil. 


\section{FRAGARIA.}

Perennial herbs; acaulescent, producing new plants at the ends of long runners; leaves trifoliate, long-petioled; flowers in long-peduncled cymes ; calyx 5-bracted, persistent, 5-parted; petals 5; stamens many; pistils many, forming achenes which are inserted on a fleshy receptacle.

1. F. Virginiana. Duchesne. Wild Strawberry. Leaflets thick, oval to obovate, coarsely serrate, somewhat hairy; scape usually shorter than the petioles, few-flowered; fruit ovoid, achenes imbedded in deep pits. March-May. Common.

2. F. vesca L European Strawberry. Leaflets ovate or broadly oval, dentate above, cuneate below, slightly hairy; scape usually longer than the petioles; fruit globular or oval, achenes adherent to the nearly even surface of the receptacle. March-May. Common in cultivation. Many of the cultivated varieties of strawberry are hybrids between the two described above.

\section{DUCHESNEA.}

Perennial herbs; acaulescent, spreading and multiplying by leafy runners; leaves trifoliate; flowers axillary, longpeduncled; calyx 5-bracted, 5-parted; petals 5; stamens numerous; pistils numerous; achenes numerous on an enlarged receptacle.

D. Indica (Andr.) Focke. Strawberry Geranium. Leaflets oval or round-obovate, crenate, obtuse at the apex; peduncles 1 flowered ; petals yellow ; fruit insipid. April-June. In waste places, escaped from cultivation.

\section{POTENTILLA.}

Herbs or shrubs; leaves palmately or pinnately compound; flowers perfect, solitary or cymose; calyx persistent, 5bracted, 5-cleft; petals 5, obcordate; stamens numerous; carpels numerous, inserted on a dry, pubescent receptacle, style terminal or lateral, deciduous.

P. Canadensis L. Cinqueforl. Perennial herbs; stem simple, trailing or ascending, 2-3 ft. long; leaves palmately 5-foliate; 
leaflets oval or oblong, serrate toward the apex, entire below ; flowers yellow, solitary, on long axillary peduncles ; petals oval, a little longer than the sepals; style terminal. June-August. In dry meadows.

\section{GEUII.}

Perennial herbs ; leaves pinnately divided ; flowers solitary or in cymose clusters; calyx persistent, 5-bracted, 5-lobed; petals 5 ; stamens and achenes numerous; styles long, straight and smooth, or jointed and hairy.

G. Canadense Jacq. White Avens. Stem erect, branching above, smooth or finely pubescent, $18-24 \mathrm{in}$. high; radical leaves pinnate, or the earliest simple and rounded, long-petioled, serrate or dentate, terminal lobe larger than the lateral lobes; stem leaves short-petioled, 2-5-lobed or parted; flowers on slender peduncles; petals white, not longer than the sepals; styles jointed near the middle, the lower portion persistent and hooked; ovaries and receptacle hairy, head of fruit globose. April-May. Rich woods.

\section{AGRIMONIA.}

Perennial herbs; stem erect; leaves unequally pinnate, stipules leafy; flower's small, yellow, in spicate racemes; calyx tube obconic, 5-cleft, covered with hooked bristles; petals 5 , small ; stamens $5-15$; achenes 2 , included in the calyx tube, fruit drooping.

A. Parviflora Sol. Agrimony. Stem branched, hirsute, 3-6 $\mathrm{ft}$. high; leaves very numerous; leaflets $9-15$, about $1 \mathrm{in}$. long, lanceolate or oblong, serrate, roughish above, pubescent below, glandular; small leaf-segments often alternating with the leaflets; flowers numerous, in long spike-like racemes, small, yellow ; mature fruit reflexed, glandular-bristly. July-August. On dry ground.

\section{ROSA.}

Shrubs; stems erect, sometimes climbing, armed with prickles; leaves pinnately compound, stipules adnate to the petioles; calyx 5-cleft, the tube urn-shaped, becoming fleshy in fruit; petals 5, spreading; stamens and pistils numerous, carpels many, usually pubescent, inserted on the receptacle which covers the inuer side of the calyx tube; achenes bony. 
[Most of the cultivated roses have many of the stamens transformed into petals, forming what are known as double flowers. A large portion of those commonly found in gardens are hybrids of several Asiatic species.]

1. R. Setigera Michx. Clmining Rose. Stem long, climbịng or reclining, somewhat prickly but not bristly; leaflets $3-5$, ovate, acute, sharply serrate, smooth and shining above, stipules narrow; petioles and peduncles somewhat glandular-pubescent; flowers in terminal corymbs, red or pink, 2-3 in. wide; calyx glandular, sepals finally deciduous; styles cohering in a column; fruit globose, smooth or slightly glandular. May-June. Borders of swamps. Often cultivated.

2. R. humilis Marsh. Pasture Rose. Stem erect, branched, usually armed with stout stipular prickles and with bristles, but sometimes nearly smooth, 1-3 ft. tall; leaves mostly 5-foliate, stipules entire; leaflets oblong-lanceolate or oval, shining above, pale beneath, sharply serrate; flowers solitary or 2-3 together, 2-3 in. broad, pink; pedunsles and calyx glandular-pubescent; calyx lobes foliaceous, spreading, finally deciduous; styles distinct; fruit globose, hispid. May-June. On dry soil ; our most common wild rose.

3. R. rubiginosa L. Sweetbrier. Stem erect or curving, armed with stout recurved prickles; leaves 5-7-foliate; leaflets broadly oval, coarsely serrate, glandular-hispid beneath, aromatic; flowers usually solitary, white or pink; sepals widely spreading, deciduous; fruit obovate, slightly hispid. May-June. Common in cultivation.

4. R. Laevigata Michx. Cherokee Rose. Stem long, diffuse or trailing, armed with very stout recurved prickles; leaves mostly 3 -foliate, persistent; leaflets smooth and shiny, lanceolate, hispid below along the mid-rib, stipules deciduous; flowers solitary, large, white; calyx very bristly; fruit globose. April-May. Common in cultivation and along fences.

\section{POMACE Æ. APPLE FAMILY.}

Trees or shrubs; leaves alternate, petiolate, stipulate, pinnately veined, or pinnately compound; flowers perfect, regular, solitary or clustered; calyx 5-parted, its tube coherent with the ovary; petals 5 ; stamens usually numerous, both petals and stamens inserted on the tube of the calyx; styles 
2-5, distinct or united at the base, ovary usually 5-celled, carpels leathery, 1-4-seeded; fruit fleshy, formed of the thickened walls of the calyx-tube and ovary.

\section{PYRUS.}

Trees; leaves simple, stipules small, deciduous; flowers in terminal cymes, large, white or pink; calyx urn-shaped, 5-cleft, sepals acute; petals rounded, short-clawed; stamens numerous; styles 5, distinct or slightly united at the base; fruit pear-shaped, flesh with numerous hard grains.

P. communis L. Pear. A tree, often very large, head usually pyramidal; branches often thorny; leaves thick and leathery, ovate or oval, acute, finely serrate or entire, pubescent when young, becoming smooth with age; petioles slender; cymes few-several-flowered, terminal, and at the ends of "fruit spurs" grown the previous season; flowers white; styles not united; fruit obovate. March-April. A European and Asiatic tree common in cultivation.

\section{MALUS.}

Trees or shrubs; leaves simple, toothed or lobed, stipules deciduous; flowers cymose, white or pink; calyx tube urnshaped, 5-lobed, lobes acute, spreading, persistent; styles $2-5$, mostly 5 , united at the base; ovary 5 -celled, seeds 1-4 in each cell; fruit globose, usually depressed or hollowed at the extremities, flesh without hard grains.

1. M. angustifolia (Ait.) Michx. Crab-apple. A small tree with smooth, light gray bark; leaves lanceolate or oblong, serrate, pubescent when young, acute at the base, short-petioled; corymbs few-flowered; flowers pink, fragrant, about 1 in. broad; styles smooth, distinct; fruit nearly globose, about $\frac{3}{4}$ in. in diameter, very sour. March-April. In open woods.

2. M. Malus (L.) Britt. Apple. A tree with a rounded top and dark-colored bark; leaves oval or ovate, obtuse or pointed, dentate or nearly entire, rounded at the base, smooth above, pubescent beneath; cymes few-many-flowered ; flowers large, white or pink ; calyx pubescent; fruit depressed-globose to ovoid, hollowed at the base and usually at the apex. March-April. Cultivated from Europe. 


\section{CYDONIA.}

Shrubs ; very similar to Malus, but flowers usually solitary; carpels many-seeded, and fruit tomentose.

1. C. vulgaris Pers. Quince. Shrub 6-12 ft. high; leaves oblong-ovate, acute at the apex, obtuse at the base, entire, tomentose below; flowers large, white or pink; fruit ovoid, tomentose. March-April. Cultivated.

2. C. Japonica Pers. JaPAN Quince. A widely branching shrub, 3-6 ft. high, branches with numerous straight spines; leaves ovate-lanceolate, acute at each end, glabrous and shining, serrulate; stipules conspicuous, reniform; flowers in nearly sessile axillary clusters, bright scarlet ; fruit globose, rare. February-April. Common in cultivation.

\section{AMELANCHIER.}

Shrubs or small trees with smooth gray bark; leaves simple, sharply serrate, petioled; flowers white, in racemes; calyx tube 5-cleft, adnate to the ovary; petals oblong; styles 5 , united below, ovary 5 -celled, 2 ovules in each cell, often only 1 maturing; fruit small, berry-like.

A. Canadensis (L.) Medic. Service Berry. A small tree, branches tomentose when young, soon becoming smooth; leaves ovate to elliptical, finely and sharply serrate, acute at the apex, usually obtuse or cordate at the base; racemes slender, many-flowered, appearing before or with the leaves; flowers showy; petals 4 or 5 times the length of the smooth sepals; fruit globose, dark red, edible. February-March. In rich woods; extremely variable in height, and in shape of leaves.

\section{CRAT EEGUS.}

Shrubs or small trees, mostly with numerous strong spines, wood very hard; leaves serrate, lobed or deeply incised, petioled; flowers white or pink, in terminal corymbs or sometimes solitary; calyx tube urn-shaped, 5-cleft, the limb persistent; petals orbicular; stamens few or many; styles $1-5$, distinct, ovules 1 in each cell; fruit a small pome with bony carpels.

1. C. Crus-Galli L. Cockspur Thorn. Small trees with spreading branches; spines usually numerous, long and stout, but 
sometimes few or wanting; leaves thick, oval or obovate, shining above, paler below, obtuse or acute, and sharply serrate at the apex, cuneate and entire at the base; corymbs terminal, many-flowered, smooth ; flowers about $\frac{1}{2}$ in. wide ; styles $1-3$; fruit red, subglobose, $\frac{1}{2}$ in. in diameter. April-May. Common in open woods.

2. C. Spathulata Michx. Small-fruited Haw. A small tree, young twigs tomentose; spines 1-2 in. long; leaves small, spatulate, crenate at the rounded apex, entire and cuneiform below, coriaceous, glabrous, stipules lunate; corymbs compound, manyflowered; flowers small; calyx lobes very short; styles 5 ; fruit red, about the size of a small pea. March-April. On river banks.

3. C. apiffolia (Marsh) Michx. Cut-leaved Haw. A small tree with stout spines; the young branches, leaves, and corymbs whitened with short hairs; leaves long-petioled, broadly deltoid, deeply incised and toothed; corymbs compound, many-flowered; flowers about $\frac{1}{2}$ in. broad; calyx lobes linear, glandular-pubescent; styles 1-3, filiform; fruit bright red, glabrous, small. March-April. River swamps.

4. C. Flava Ait. Yellow Haw. A small tree with very numerous spines; leaves obovate, glandular-serrate at the rounded apex, cuneate below, pubescent when young; petiole short; corymbs few-flowered, slightly pubescent; flowers $\frac{1}{2}-\frac{3}{4}$ in. wide; calyx lobes entire or glandular-serrate; styles $4-5$; fruit pear-shaped, $\frac{1}{2}$ in. or more in length, greenish-yellow. April-May. On sandy soils.

\section{DRUPACEAE. PLUM FAMILY.}

Trees or shrubs; leaves alternate, simple, often glandular; stipules soon deciduous; flowers clustered or solitary, perfect, regular; calyx tube obconic, limb 5-parted; petals 5; stamens numerous, both petals and stamens inserted on the summit of the calyx tube; pistil 1, style 1, stigma usually capitate, ovary 1-celled, 2 -ovuled, but usually only one ovule maturing; fruit a drupe.

\section{PRUNUS.}

Trees or shrubs, often spiny; leaves serrate; flowers mostly in axillary clusters; calyx 5-cleft, deciduous; petals 5, spreading; stamens $15-25$; style terminal; fruit a drupe, exocarp fleshy, smooth, endocarp hard and bony, somewhat roughened, oval and compressed or subglobose. 
A. Stone oval, compressed, leaves convolute in the bud, branches often spiny. (Plums.)

1. P. Americana Marsh. Wild Plum. A small tree, bark thick and rough, branches spiny; leaves ovate or obovate, acuminate at the apex, rounded or cordate at the base, sharply serrate, rather thick, pubescent beneath; petioles glandular; flowers in lateral, sessile umbels, appearing with or before the leaves; pedicels $\frac{1}{2}-\frac{3}{4}$ in. long; flowers $\frac{1}{2}-\frac{3}{4}$ in. in diameter; calyx pubescent within; drupe globose, red or yellow, $\frac{1}{2}-1$ in. in diameter. March-April. Common in woods.

2. P. angustifolia Michx. Chickasaw Plum. A small tree with spiny branches; leaves lanceolate or oblong-lanceolate, acute at the apex, usually obtuse at the base, finely and sharply serrate, rather thin, smooth; flowers in lateral, sessile umbels, pedicels short; calyx smooth; drupe yellowish-red, subglobose, skin thin, stone only slightly compressed. March-June. In old fields.

B. Stone globose or slightly compressed, leaves folded in the bud, branches not spiny. (Cherries.)

3. P. serotina Ehrh. Wild Black Cherry. Often becoming a large tree; bark on old trees rough, nearly black; leaves rather thick, oval to lanceolate-ovate, acute or acuminate at the apex, finely serrate with calloused teeth, glabrous above, pubescent on the veins beneath; racemes terminal, long and spreading; flowers white; drupes globose, about $\frac{1}{4}$ in. in diameter, purplish-black. April-May. In rich woods.

4. P. Caroliniana Ait. Cherry Laurel. A small tree; leaves evergreen, coriaceous, smooth and shiny, ovate or ovatelanceolate, acute, nearly entire; racemes axillary, shorter than the leaves; flowers white; drupe small, black, ovoid, not edible, soon becoming dry. February-March. On river banks, and often cultivated for ornament.

5. P. Cerasus L. Cherry. Often becoming a large tree; leaves oval or ovate, acute or acuminate at the apex, rounded at the base, irregularly serrate-dentate, smooth on both sides, resinous when young; flowers in lateral umbels, white; pedicels long and slender; drupe globose, red or black. March-April. This is the European species from which most of our cultivated varieties have been developed.

\section{AMYGDALUS.}

Small trees; leaves simple, lanceolate, serrate, shortpetioled; flowers solitary or clustered, like those of Prunus ; 
exocarp Hleshy, velvety, endocarp hard and bony, compressed, deeply furrowed and pitted.

A. Persica L. Peach. A tree with a rounded top; bark nearly smooth; leaves lanceolate, acuminate, finely serrate, smooth on both sides; petioles usually bearing 2 or 4 crescent-shaped or cup-shaped glands; flowers pink, scaly-bracted; drupe ovoid, with a suture along one side. February-March. Often escaped from cultivation.

\section{CHRYSOBALANUS.}

Low shrubs; leaves nearly sessile, entire; stipules minute; flowers in terminal and axillary cymes or panicles, small; calyx 5-cleft, persistent; petals 5 ; stamens numerous ; pistil 1 , ovary with 2 ovules of which only 1 matures; fruit a drupe.

C. oblongrfolius Michx. Hog Plum. Bush low and straggling, seldom more than $1 \mathrm{ft}$. in height, unarmed; leaves coriaceous, narrowly obovate or cuneiform, mucronate, smooth on both sides or pubescent beneath, 3-4 in. long; cymes mostly terminal, manyflowered, but most of the flowers abortive, greenish-yellow; calyx pubescent; ovary smooth ; drupe ovoid, nearly white, 1 in. or more in length, edible, stone grooved on one side. April-May. Dry sandy barrens.

\section{MIMOSACEÆ. MIMOSA FAMILY.}

Herbs, shrubs or trees; leaves alternate, pinnate, sometimes 2-3 times pinnately compound; stipules small ; flowers in long-peduncled heads or racemes, regular, hypogynous; petals 3-6, distinct or slightly united; stamens as many as the petals or more numerous, distinct or united; pistil 1 , ovary 1-celled, ovules several; fruit a legume.

\section{ACUAN.}

Shrubs or perennial herbs; stems erect or diffuse, smooth; leaves abruptly twice-pinnate; stipules small; flowers in heads or spikes on axillary peduncles, the upper perfect, the lower often staminate or neutral; calyx 5-toothed; corolla of 
5 distinct petals or 5 -cleft; stamens 5-10, distinct; ovary nearly sessile, flat, several-seeded.

A. Illinoensis (Michx.) Kuntze. Desmanthus. Stem erect or ascending, glabrous, $1-4 \mathrm{ft}$. high ; pinnæ $6-14$ pairs, each with a minute gland at the base ; leaflets $20-30$ pairs, small, linear; heads globose; stamens 5; legumes several, on a peduncle 2-3 in. long, curved, flat, 2-valved, 3-6-seeded. May-July. Open sandy fields.

\section{MORONGIA.}

Perennial herbs; stems decumbent or prostrate, prickly, 2-5 ft. long; leaves bi-pinnate; stipules setaceous; flowers perfect or polygamous, in axillary peduncled heads; calyx minute; corolla tubular, 5-cleft; stamens 8-10, distinct; legume long, prickly, 1-celled.

M. Angustaia (T. \& G.) Britt. Sensitive-brier. Stem armed with numerous, weak, recurved prickles; leaves petioled, pinnæ 4-6 pairs; leaflets $12-15$ pairs, linear, elliptical, very faintly veined; flowers pink, in dense heads, peduncles shorter than the leaves; legumes narrowly linear, long-pointed, prickly, 4-valved, several-seeded. May-August. On dry soil.

\section{ACACIA.}

Trees or shrubs; leaves pinnately compound or decompound; flowers perfect or polygamous, in spikes or heads; calyx 4-5-toothed; petals 4-5, distinct or united; stamens numerous, distinct; legumes 2 -valved, many-seeded.

1. A. Farnesiana Willd. Opoponax. Shrubs; stem spiny, branching, glabrous, 2-4 ft. high ; leaves twice-pinnate; leaflets very numerous, small, narrowly oblong; stipules large spines; heads on long axillary peduncles; flowers yellow, fragrant; legume long and slender, twisted. May-July. Introduced in waste places.

2. A. Julibrissin Willd. Crimson Acacia. A large shrub; stem erect, smooth, glabrous; leaves decompound, pinnæ 8-12 pairs ; leaflets 25-30 pairs, oblong, oblique; heads few-flowered, in terminal panicles; flowers large; stamens bright crimson, exserted, 3-4 in. long; legume flat, few-seeded. May-July. Introduced and escaped from gardens. 


\section{CASALPINACE $\notin$. SENNA FAMILY.}

Trees, shrubs or herbs; leaves simple or compound, alternate, usually stipulate; flowers variously clustered, perfect, polygamous or monœcious, regular, or irregular and somewhat papilionaceous; calyx usually of 5 distinct or united sepals; petals usually 5 , the upper enclosed by those on the sides; stamens 10 or less, usually distinct; ovary 1-celled, usually several-seeded, fruit a legume.

\section{CERCIS.}

Trees ; leaves simple, stipulate; flowers in axillary clusters, papilionaceous; calyx bell-shaped, 5-toothed; stamens 10, distinct; ovary short-stipitate, ovules several; fruit a flattened legume.

C. Canadensis L. Rediud. A small tree, 10-20 ft. high, wood hard but weak, bark smooth, dark-colored ; leaves broadly cordate, abruptly acute, rather thick, very smooth above, often slightly pubescent below; flowers several in a cluster, appearing before the leaves, pinkish-purple; legume oblong, compressed, many-seeded. February-March. Common on rich soil.

\section{CASSIA.}

Shrubs or herbs; leaves abruptly pinnately compound, stipulate; flowers mostly yellow; sepals nearly regular, slightly united below; petals 5 , somewhat unequal ; stamens 5 or 10 , often partly irregular or abortive; legume manyseeded, seeds often separated by cross partitions.

1. C. Tora L. Low Senna. Annual herbs; stem stout, erect, branched, glabrous, 2-3 ft. high; leaves petioled; leaflets usually 6 , $1-1 \frac{1}{2}$ in. long, obovate, mucronate, entire, with a small slender gland between the lowest pair ; stipules deciduons; flowers usually in pairs, $\frac{3}{4}-1$ in. broad; stamens 10 , the anthers of 3 being imperfect; legume linear, curved, 4-6 in. long. June-August. On rich moist soil.

2. C. occidentalis L. Coffee Senna. Annual; stem erect, widely branched, glabrous; leaves petioled; leaflets 8-12, 1-2 in. long, broadly lanceolate, acuminate at the apex, rounded at the 
base, entire, glabrous, glands 2, conical ; stipules subulate, deciduous; flowers in 2-4-flowered axillary racemes, $\frac{2}{3}-\frac{3}{4}$ in. broad ; stamens 10, the 3 upper abortive; pod linear, erect, slightly curved, 3-4 in. long. June-August. Common in waste places.

3. C. Cham ecrista L. Large-flowered Sensitive-plant. Annual; stem erect, widely branched and 1-2 ft. high, or nearly simple and 3-5 ft. high, rusty-pubescent or nearly smooth; leaves very sensitive, petioled ; leaflets about $\frac{1}{2}$ in. long, linear-oblong, mucronate, petiolar gland cup-shaped; stipules nerved, persistent; flowers 2-5 together, on axillary pedicels, $1-1 \frac{1}{2} \mathrm{in}$. wide; petals yellow, often spottel with purple; stamens 10, all perfect; legume linear, pubescent, several-seeded. June-August. Common in waste places.

4. C. nictitans L. Wild Sensitive-plant. Annual; widely branched, stem smooth or pubescent, 10-18 in. high ; leaflets 20-40, linear-oblong, mucronate, $\frac{1}{3}-\frac{2}{3}$ in. long; petiolar gland urn-shaped ; stipules persistent, lanceolate, veined ; flowers small, 2-3 together in nearly sessile axillary clusters; stamens 5 ; legume pubescent, narrowly oblong, few-seeded. June-October. Common on dry soil.

\section{GLEDITSIA.}

Large trees; bark dark-colored, nearly smooth; leaves usually pinuately decompound ; leaflets serrate ; flowers polygamous, in small spike-like racemes; calyx spreading, 3-5cleft; petals as many as the sepals and inserted at the summit of the tube; stamens 5-10, distinct, inserted with the petals; ovary nearly sessile, ovoid or elongated; fruit a legume, 1 or many-seeded, pod coriaceous.

G. triacantios L. Honey Locust. A large tree, usually armed with stout, branched thorns which are sometimes a foot or more in length; leaves petioled, decompound; leaflets short-stalked, lanceolate-oblong, bas inequilateral, smooth abore, often pubescent below; racemes solitary or in small clusters, drooping; flowers inconspicuous, greenish; legume linear-oblong, often 12-15 in. long by 1 in. wide, twisted, many-seeded, glabrous and shiny, pulpy within. June-July. In rich woods. [The thorns are plainly modified branches bearing dormant buds, and often partially developed leaves. The early spring leaves are usually only once compounder, while those of later growth are almost invariably decompound. Often a single leaf will show both forms of compounding.] 


\section{PAPILIONACE ZE. PEA FAMILY.}

Trees, shrubs, herbs or woody vines; leaves alternate, stipulate, mostly compound; flowers irregular, usually perfect, solitary or variously clustered; calyx 4-5-cleft or lobed, sometimes 2-lipped; petals 5, the upper and outer one (the standard) usually longer than the others and enclosing them, the two lateral (the wings) usually spreading, and the two lower (the keel) folded together and often united; stamens mostly 10, monadelphous or diadelphous, rarely distinct; corolla and stamens inserted in the base of the calyx ; pistil 1, ovary 1-celled or sometimes 2-celled by the inwardly projecting suture, and sometimes transversely several-celled; fruit a legume, 1-many-seeded.

Leaves trifoliate.

Legume several-seeded.

Plants erect.

Legume inflated . . . . . I. Baptisia.

Legume nodulose . $\quad . \quad$. . XXVIII. Erythrina.

Legume separating into joints . XVII. Meibomia.

Plants twining or trailing.

Keel spirally twisted.

Inflorescence racemose . .

XXVI. Phaseolus.

Inflorescence capitate

XXVII. Strophostyles.

Keel not twisted.

Calyx 5-toothed.

Standard spurred . . .

XXI. Bradburya.

Standard not spurred . . . XXII. Clitoria.

Calyx 4-toothed . . . . XXIV. Galactia.

Legume 1-few-seeded.

Leaflets serrate or denticulate.

Legume coiled

IV. Medicago.

Legume not coiled.

Flowers racemed

Flowers capitate

V. Melilotus.

VI.'Trifolium. 
Leaflets entire.

Leaflets glandular dotted.

Flowers yellow . . . XXV. Rhynchosia.

Flowers white or purplish . VII. Psoralea.

Leaflets not dotted.

Flowers yellow

Flowers white or purplish . X XIII. Lespedeza.

Leaves odd-pinnate.

Stems woody.

Shrubs

Twining vines. . .

Trees . . . .

Stems herbaceous, erect or diffuse.

Keel spurred, pod 4-angled

Keel not spurred, pod flat

Stems herbaceous, twining ... .

VIII. Amorplıa.

$\mathrm{X}$. Kraunhia.

XI. Robinia.

XII. Indigofera.

IX. Cracca.

XXIII. Apios.

Leaves abruptly pinnate.

Leaves with tendrils.

Style bearded on the side nearest the keel

XIX. Vicia.

Style bearded on the side opposite the keel . . . .

XX. Lathyrus.

Leaves without tendrils.

Legume 2-seeded . . . X XIII. Glottidium.

Legume many-seeded . . X XIV. Sesban.

Leaves palmately compound.

Leaflets several

Leaflets 2 or 4 . . . . XVI. Zornia.

Leaves simple.

Legume inflated . . .

II. Crotalaria.

Legume flat, flowers yellow . XXV. Rhynchosia.

Legume flat, flowers blue, pink or white

III. Lupinus.

\section{BAPTISIA.}

Perennial herbs; stems erect, widely branched; leaves simple or palmately trifoliate; flowers in racemes; calyx 4 5-lobed, persistent, the upper lobe usually longer and emar- 
ginate; standard orbicular, its sides reflexed, wings about as long as the keel; stamens 10, distinct; the pod stipitate, long-pointed by the remains of the style; plants usually becoming black in drying.

1. B. Lanceolata Ell. Narrow-leaved False Indigo. Stem pubescent when young, becoming smooth with age, 18-24 in. high; leaves trifoliate, on short petioles; leaflets lanceolate to obovate, obtuse at the apex, narrowed to the base, rather thick; stipules small and soon deciduous; flowers yellow, axillary and solitary, or in short racemes; ovary densely pubescent; mature legume globose or ovoid, coriaceous, long-pointed ; plant blackening in drying. AprilMay. Dry pine barrens.

2. B. tinctoria R. Br. Wild Indigo. Stem smooth, slender, 2-4 ft. high; branches slender; leaves trifoliate, on short petioles, the upper nearly sessile; stipules minute, quickly deciduous ; leaflets obovate to oblanceolate, obtuse at the apex, cuneate at the base, entire; racemes numerous, terminal; flowers yellow, $\frac{1}{2}$ in. long; legume globose-ovoid, on a stipe about the length of the calyx, point long and slender; plant blackening in drying. May-June. Common on dry, sandy soil.

3. B. Alba (L.) R. Br. White Wild Ixdigo. Stem smooth and glaucous, often purple, 2-3 ft. high; branches slender, spreading; leaves petioled, trifoliate; stipules minute, soon deciduous; flowers white, mostly in a single raceme which is $1-3 \mathrm{ft}$. long, with occasionally lateral, few-flowered racemes; pod linear-oblong, the point very slender and soon deciduous; plant unchanged in drying. April-May. In damp soil.

4. B. australis (L.) R. Br. Blue False Indigo. Stem smooth and glabrous, stout, 2-4 ft. high; leaves trifoliate, shortpetioled; stipules lanceolate, persistent, longer than the petioles; leaflets oblong, wedge-shaped or narrowly obovate, entire; flowers bright blue, 1 in. long, in terminal, erect, loosely flowered racemes; stipe about the length of the calyx; pod oblong, with a slender, persistent point. May-July. Banks of rivers; often cultivated for ornament.

\section{CROTALARIA.}

Annual or perennial herbs, sometimes with a woody base; leaves simple; stipules inversely sagittate and decurrent; flowers yellow, in few-flowered racemes opposite the leaves; calyx 5-toothed and often 2-lipped; standard cordate, keel falcate; stamens monadelphous, 5 of the anthers smaller 
and more rounded than the others; pod inflated and purple at maturity, seeds many, becoming loose in the pod.

1. C. Sagittalis L. Rattle-box. Annual; stem widely branching, 3-6 in. high, clothed with brownish hairs; leaves nearly sessile, oval or oblong-lanceolate, hairy ; stipules often wanting below ; racemes short, 2-3 flowered; corolla about the length of the calyx; pod oblong, glabrous, much inflated. May-July. Barren, sandy soil.

2. C. Purshit DC. Narrow-leaved Rattle-box. Perennial; root slender-fusiform; stems erect, slender, with scattered hairs, 12-18 in. high; lower leaves oval or oblong, the upper linear, thick and fleshy; racemes 6-12 in. long, 5-10-flowered, flowers distant; corolla much longer than the calyx; pod inflated, dark purple. May-June. Grassy pine barrens.

\section{LUPINUS.}

Biennial or perennial herbs ; leaves simple or palmately compound; flowers showy, in terminal racemes; calyx 2-lipped, 5-toothed; standard orbicular, with the sides reflexed, keel falcate; stamens monadelphous, anthers alternately oblong and roundish; ovary sessile; matured pod oblong, severalseeded, often compressed between the seeds.

1. L. vileosus Willd. Woolly Lupine. Biennial; stem erect, branching at the base, 12-18 in. high; leaves simple, long-petioled, narrowly oblong or elliptical, acute at each end; stipules linear, sometimes $2 \mathrm{in}$. long, adnate to the petiole below; flowers red and purple, in dense terminal spikes or racemes $6-10$ in. long; legume oblong; whole plant densely silvery-tomentose. April-May. Dry, sandy barrens.

2. L. Perenvis L. Perennial; stem erect, pubescent, 12-18 in. high ; leaves palmately $7-9$ foliate ; leaflets obovate or oblanceolate, obtuse and mucronate at the apex, slightly pubescent; petiole slender; stipules sniall; racemes terminal, slender, loosely manyflowered; flowers purple, blue, pink or white; legume oblong, densely pubescent, few-seeded. April-May. Dry, sandy soil.

\section{MEDICAGO.}

Annual or perennial herbs; leaves petioled, trifoliate; leaflets toothed; flowers in terminal and axillary spikes or racemes; calyx 5-toothed, the teeth short and slender; stand- 
ard oblong, much longer than the wings or keel; stamens 10 , diadelphous; ovary sessile; legume 1-several-seeded, coiled, indehiscent, often spiný.

1. M. sativa L. Alfalfa. Perennial; stems erect, branching, pubescent when young, becoming smooth with age, 2-3 ft. high; leaves short-petioled; leaflets obovate, sharply dentate towards the apex, obtuse or sometimes emarginate or mucronate; stipules lanceolate, entire; flowers blue, small, in rather close spikes; legumes pubescent, coiled, few-seeded. April-September. Introduced from Europe, and cultivated for hay and pasture.

2. M. Arabica All. Bur Clover. Annual; stem procumbent, glabrous or slightly pubescent, 1-3 ft. long; leaves long-petioled; leaflets obcordate, toothed above, usually with a dark spot near the center; stipules inequilateral, incised or toothed; flowers small, yellow, in globose spikes; mature legume nearly globose, several times coiled, reticulated and spiny-toothed. April-June. Introduced from Europe and often cultivated for pastures.

\section{MELILOTUS.}

Annual or biennial herbs; leaves petioled, trifoliate; flowers small, white or yellow, in dense axillary and terminal racemes; calyx 5 -toothed, the teeth nearly equal; standard erect, wings and keel cohering; stamens 10, diadelphous; legume longer than the calyx, 1-4-seeded.

M. Alba Desv. Melilotus. Biennial; stem erect, branching, smooth or the young branches slightly pubescent; leaflets oblong or oblanceolate, rounded or truncate at the apex, serrate; stipules small; racemes long, slender, erect; flowers white; standard longer than the wings and keel; legume ovoid, rugose, drooping, mostly 1-seeded, scarcely dehiscent. April-October. Common on lime soil and widely cultivated.

\section{TRIFOLIUM.}

Annual, biennial or perennial herbs; stems more or less diffuse; leaves petioled, trifoliate; leaflets toothed or serrate; stipules adnate to the petioles; flowers white, yellow or red, in heads; calyx 5-cleft, the teeth nearly equal and subulate; petals withering-persistent, keel shorter than the wings; stamens diadelphous; legume smooth, 1-6-seeded, scarcely dehiscent. 
1. T. procumbens L. Low Hop-clover. Annual; stem slender, erect, diffuse or decumbent, pubescent, 6-10 in. long; leaves short-petioled; leaflets obovate or obcordate, finely dentate, the middle one distinctly stalked; stipules lance-ovate; flowers yellow, reflexed in fruit; legume 1-seeded. February-April. Common on clay soil in waste places.

2. T. incarnatum L. Crimson Clover. Annual; stem erect, somewhat branched, pubescent, 1-2 ft. high; lower leaves long-, the upper short-petioled; leaflets obovate or cuneate, toothed at the apex ; flowers bright crimson, sessile, in terminal heads which finally become much elongated; calyx silky, its lobes long and plumose. March-April. Introduced and cultivated for fodder.

3. T. pratense L. Red Clover. Biennial or short-lived perennial ; stems diffuse, branching, becoming decumbent, pubescent, 1-3 ft. long; leaves long-petioled; stipules large; leaflets oval to obovate, finely toothed, often with a dark triangular spot near the center; flowers red or purple, in globose heads, erect in fruit; calyx teeth setaceous, hairy; legume 1-3-seeded. April-September. Introduced and widely cultivated.

4. T. reflexum L. Buffalo Clover. Annual or biennial; stem erect or ascending, pubescent, 8-15 in. long; leaves longpetioled; stipules ovate, acuminate; leaflets obovate, denticulate, prominently straight-veined; heads globose, peduncled; flowers rather large, reflexed in fruit; calyx shorter than the corolla, the teeth linear; standard red or pink, wings and keel white; legume 3-5seeded. April-May. Along fences and ditch banks on rich soil.

5. T. Carolinianum Michx. Carolina Clover. Perennial; stems diffuse or ascending, much-branched, pubescent, 6-10 in. long; leaves short-petioled; leaflets small, obovate or obcordate, slightly toothed; heads small, globose, on long peduncles; flowers white, tinged with purple, reflexed in fruit; legume 4-seeded. March-April. Common in waste places.

6. T. repens L. White Clover. Perennial; stems widely branching at the base, prostrate and creeping, nearly smooth, 6-12 in. long; leaves long-petioled; leaflets oval, obovate or obcordate, denticulate; heads globose, long-peduncled; flowers white, reflexed in fruit; legume 3-4-seeded. April-November. Introduced; common about houses and in pastures.

\section{PSORALEA.}

Perennial herbs; whole plant glandular-dotted; leaves 3-5foliate; stipules cohering with the petioles; flowers in axillary or terminal spikes or racemes; calyx 5-cleft, the lobes 
nearly equal; standard ovate or orbicular, keel incurved, obtuse; stamens monadelphous or diadelphous, 5 of the anthers often abortive; ovary nearly sessile; pod included in the calyx, often wrinkled, indehiscent, 1-seeded.

P. Pedunculata (Mill.) Vail. Samson's Snakeroot. Stem erect, slender, branching above, pubescent, 1-2 ft. high; leaves trifoliate; petioles shorter than the leaflets; stipules subulate; leaflets elliptical or oblong-lanceolate, sparingly glandular-dotted, the terminal one stalked; loosely flowered spikes axillary and terminal, on peduncles much longer than the leaves; flowers blue or purple, about $\frac{1}{3}$ in. long; pod compressed-globose, wrinkled transversely. MayJune. Dry soil.

\section{AMORPHA.}

Small shrubs, glandular-dotted; leaves odd-pinnate; flowers purple, blue or white, in slender spikes or racemes; calyx 5 -toothed, persistent; standard obovate, concave, wings and keel none; stamens monadelphous, long-exserted; ovary sessile; legume curved, glandular-roughened, 1-2-seeded, indehiscent.

1. A. Fruticosa L. False Indigo. A shrub 6-15 ft. high, with smooth, dark-brown bark; leaves petioled; leaflets 15-21, short-stalked, oblong, obtuse or emarginate, sparingly punctate with pellucid dots ; slender flowering spikes panicled or solitary, 4-6 in. long; flowers blue or purple ; calyx teeth short, nearly equal, pubescent; pod glandular. May-June. River banks.

2. A. Canescens Pursh. Lead-Plant. A diffuse shrub 1-2 ft. high; branches and leaves covered with a dense, lead-colored pubescence; leaves sessile; leaflets very numerous, crowded, small, elliptical; spikes short, clustered, densely flowered; flowers bright blue; pod a little longer than the calyx, 1-seeded. June-July. On dry hills.

\section{CRACCA.}

Perennial herbs; leaves odd-pinnate; stipules small; leaflets entire ; flowers in terminal and axillary racemes or clusters ; calyx about equally 5-cleft; standard orbicular, reflexed, silky on the outside, about as long as the coherent wings and keel; stamens monadelphous or diadelphous; legume linear; compressed, several-seeded. 
1. C. Virginiana L. Catgut. Root long, slender and very tough ; stems clustered, erect, slender, seldom branched, silky-pubescent, 1-2 ft. high ; leaves nearly sessile ; leaflets 15-25, linear-oblong, acute or obtuse, smooth above, white-canescent below; racemes mostly in a dense terminal cluster; flowers large, showy, yellowishpurple; pod linear, straight, densely pubescent. June-July. Dry pine barrens.

2. C. spicata (Walt.) Kuntze. Goat's Rue. Stems diffuse, simple or branched, villous with rusty hairs; leaves scattered, shortpetioled; leaflets $9-15$, oval, strongly mucronate at the apex, smoothish above, hairy below; racemes opposite the leaves, peduncle slender, 6-10 in. long, 6-10-flowered; flowers large, white, becoming purple; calyx lobes linear-subulate; pod linear, pubescent, 10-12seeded. May-July. Dry pine barrens.

3. C. hispidula (Michx.) Kuntze. Goat's Rue. Stems slender, ascending or decumbent, rusty-pubescent, 1-2 ft. long; leaves short-petioled; leaflets 11-15, small, oblong, acute or obtuse, usually smooth above; peduncles lateral or terminal, slender, a little longer than the leaves, 2-4-flowered; flowers small, purple; pod linear, pubescent, slightly curved. May-July. Dry, sandy soil.

\section{KRAUNHIA.}

Twining woody vines; leaves odd-pinnate; racemes terminal; flowers large and showy; calyx 2-lipped, the upper lip 2-cleft, short, the lower longer and 3-cleft; standard large, orbicular, with 2 calloused ridges at the base, wings auriculate at the base, keel falcate; pod long, stipitate, coriaceous, 2 -valved, several-seeded.

K. Frutescens (L.) Greene. Wistaria. Stem climbing 30 $40 \mathrm{ft}$., often 2-3 in. in diameter at the base; branches and leaves pubescent when young, becoming smoother with age; leaves shortpetioled; stipules minute; leaflets $9-17$, ovate-lanceolate, acute at the apex, rounded at the base; racemes large, densely flowered; calyx pubescent; corolla lilac-purple; pod 2-3 in. long, 2-4-seeded. April-June. River banks. Often cultivated for ornament.

\section{ROBINIA.}

Trees or shrubs; leaves odd-pinnate; stipules often spiny; flowers showy, in axillary racemes; calyx short, 5-toothed, the two upper teeth shorter and partially united; standard 
large, orbicular, reflexed, keel obtuse; stamens diadelphous; style bearded on one side; legume compressed, severalseeded.

R. pseudacacia L. Black Locust. A tree of medium size; bark rough and nearly black; twigs and leaves smooth; leaflets $9-$ 15 , orate or oblong, obtuse and slightly mucronate at the apex; stipules forming persistent spines; racemes loose, pendulous, $3-5$ in. long; flowers white, fragrant; pod smooth, 4-8-seeded. April-May. Introduced and quite common ; wood very durable when exposed to the weather, and extensively used for posts.

\section{INDIGOFERA.}

Herbs or shrubs; leaves odd-pinnate; stipules small; flowers in terminal and axillary racemes; calyx 5-toothed, oblique; standard orbicular, erect, keel erect, with a spur on each side; stamens diadelphous; legume slender, 1-manyseeded.

I. leptosepala Nutt. Wild Indigo. Perennial; stem decumbent, rough hairy, 2-3 ft. long; leaves short-petioled; leaflets 59, short-stalked, linear-oblong; racemes peduncled, 6-15-flowered; flowers red; pods not stipitate, linear, pendulous, septate between the seeds which are truncate at each end. May-August. On open ground.

Besides the indigenous species described, I. TINCtoria L. and I. AnIL L. were formerly cultivated for the manufacture of indigo, and occasional plants are still found in waste places.

\section{GLOTTIDIUM.}

Annual; leaves abruptly pinnate; flowers in axillary racemes ; calyx 5-toothed, oblique ; standard erect, reniform; stamens diadelphous; style abruptly curved at the apex; legume long-stipitate, narrowly elliptical, compressed, the outer and inner coats separating at maturity, 2-seeded.

G. Floridanum (Willd.) DC. Coffee-weed. Stem yellowishgreen, smooth, erect, widely branched, 4-8 ft. high; leaflets numerous, oblong-linear; racemes long-peduncled, often compound; flowers yellow, near the summit of the peduncle; legume 2 in. long. JulySeptember. Introduced; common on dry soil. 


\section{SESBAN.}

Herbs or shrubs; leaves abruptly pinnate; flowers red or yellow, in axillary racemes; calyx equally 5-toothed, with 2 deciduous bracts; standard erect, orbicular; stamens diadelphous; ovary stipitate; legume long, slender, many-seeded.

S. macrocarpa Muhl. Long-pod Coffee-weed. Annual; stems erect, smooth, widely branched, 5-10 ft. high; leaflets very numerous, oblong-linear, obtuse, mucronate; racemes 1-4-flowered, shorter than the leaves; flowers yellow and red; legume very slender, knotted, pendulous, 4-angled, many-seeded, 8-12 in. long. JuneSeptember. Damp soil.

\section{STYLOSANTHES.}

Perennial; stems slender, branching, wiry; leaves trifoliate; stipules sheathing and adnate to the petioles; flowers in terminal heads or short spikes; calyx tube slender, campanulate, unequally 4-5-cleft, the lower lobe longer; standard erect, orbicular; stamens monadelphous, alternate stamens longer; style filiform, the upper part deciduous, the lower persistent and hooked at the end; pod 1-2-jointed, the lower joint empty.

S. BIFLoRA (L.) B. S. P. Stems diffuse or ascending, pubescent or hispid; leaflets lanceolate or elliptical, rigid, veins straight, nearly white; heads few-flowered; flowers yellow, bracts bristly; pod obovate, reticulate, 2-jointed, 1-seeded. May-August. On dry soil.

\section{ZORNIA.}

Perennial herbs; leaves petioled, palmately 2-4-foliate; stipules small, sagittate; flowers in slender, axillary racemes; floral bracts conspicuous; calyx 2-lipped, 5-cleft; standard orbicular; stamens monadelphous, alternately shorter; legume compressed, 2-5-jointed, joints 1-seeded.

Z. bracteata (Walt.) Gmel. Zornia. Stems from long and woody roots, smooth or pubescent, decumbent or prostrate, widely branched, 2-3 ft. long; leaves 4-foliate; leaflets narrowly elliptical to oblong-ovate, acute at each end; racemes 4-20-flowered, becom- 
ing much elongated in fruit; flowers yellow, nearly concealed by large, ovate, veiny bracts; pods flat, hispid, 2-5-jointed. MayAugust. Dry, sandy soil.

\section{MEIBOMIA.}

Perennial herbs; sometimes woody at the base; leaves petioled, trifoliate, stipulate; leaflets stalked, stipellate; flowers in terminal racemes or panicles; calyx 2-lipped, the upper lip entire or emarginate, the lower 3-cleft ; stamens monadelphous or diadelphous; ovary sessile or stalked; legume flattened, separating into joints, hispid with hooked hairs.

1. M. Grandiflora (Walt.) Kuntze. Pointed-Leaved BegGAR-WEED. Stem erect, glabrous or pubescent, 2-4 ft. high; leaves mostly crowded at the summit of the stem; petioles long; stipules small; leaflets thin, ovate or roundish, acuminate, smooth or slightly pubescent on both sides; panicle terminal, long-peduncled, large, many-flowered; flowers large, purple; stipe much longer than the calyx tube; legume 2-4-jointed, joints half-obovate, concave on the back, hispid. June-September. In rich woods.

2. M. nudiflora (L.) Kuntze. Naked-Flowered BeggarWEED. Stems smooth, erect, the sterile about $10 \mathrm{in}$. high, bearing a cluster of leares at its summit; leaflets orate, the middle one longstalked, acute or obtuse at the apex, often inequilateral, entire, pale beneath; fertile stems usually leafless, $1 \frac{1}{2}-3 \mathrm{ft}$. high, bearing a narrow panicle of small purplish flowers; legume long stipitate, 2-3jointed, joints straight on the back. June-August. In rich woods.

3. M. Canescens (L.) Kuntze. Hoary Beggar-weed. Stem erect, much-branched, rough, hairy, striate, $3-5$ ft. high; leaves petioled; stipules large, ovate, acuminate; leaflets ovate, usually acute, very rough, hairy; racemes terminal, compound; flowers purple, $\frac{1}{4}-\frac{1}{3}$ in. long; legume sessile, 3-6-jointed, joints convex on the back, rounded below, very hispid. June-August. Dry, open woods.

\section{LESPEDEZA.}

Annual or perennial herbs; leaves trifoliate ; flowers small, in axillary clusters, often of 2 kinds, the larger showy and perfect, but sterile, the smaller inconspicuous, pistillate and fertile; calyx tube 5-cleft, the lobes nearly equal; stamens diadelphous, anthers alike; legume small, flat, 1-seeded, indehiscent. 
1. L. repens (L.) Bart. Creeping Lespedeza. Perennial; stem slender, prostrate, spreading, smooth or slightly tomentose; leaves nearly sessile; leaflets small, oval or elliptical, obtuse or emarginate at the apex; the petaliferous flowers on slender peduncles longer than the leaves, the fertile flowers nearly sessile; legume orbicular, finely pubescent. June-September. Dry, sandy soil.

2. L. violacea (L.) Pers. Bush Lespedeza. Perennial; stem erect, spreading or diffuse, slightly pubescent, 1-3 ft. high; leaves short-petioled; stipules subulate; leaflets oval or elliptical, rounded at both ends, pubescent beneath; peduncles of the petaliferous flowers longer than the leaves, flowers rather large, purple; fertile flowers in nearly sessile axillary clusters; legume flat, oval, much longer than the calyx, smooth or slightly pubescent. Plant extremely variable in habit of growth. June-September. Common in dry woods.

3. L. striata (Thunb.) H. \& A. Lespedeza, Japan Clover. Annual; stem diffuse or ascending; slender, wiry, sparingly pubescent, 6-18 in. long; leaves numerous, nearly sessile; leaflets oblongobovate, margins ciliate; flowers in nearly sessile, axillary clusters; corolla pink or purple; pod oval, acute, longer than the calyx lobes. June-October. Introduced from Japan and very common.

\section{VICIA.}

Annual or perennial herbs ; leaves pinnate, tendril-bearing; stipules half-sagittate; flowers on axillary peduncles; calyx 5 -toothed, the two upper teeth obovate; standard obovate, emarginate, wings adherent to the keel; stamens mostly diadelphous; style filiform, hairy, at least on the side facing the keel; legume 2-several-seeded.

1. V.sativa L. Common Vetch. Annual; stem simple, smooth or pubescent, reclining, 1-3 ft. long; leaves short-petioled; leaflets 5-7 pairs, obovate-oblong to linear, obtuse, emarginate and mucronate at the apex; flowers in pairs, nearly sessile in the axils, pale purple, $\frac{3}{4}-1$ in. long; legume linear, several-seeded. March-April. Introduced from Europe and common in cultivation.

2. V. Ludoviciana Nutt. Louisiana Vetch. Perennial; stem smooth or slightly pubescent, angled, diffuse, 2-3 ft. long; leaves petioled; stipules small; leaflets 4-6 pairs, oblong or obovate, retuse at the apex; peduncles about as long as the leaves, mostly 2-flowered; flowers small, light blue; legume broadly falcate, 4-6seeded. April-May. In rich woods. 
3. V. villosa L. Hairy Vetch. Annual; stem diffuse, angled, pubescent, 4-10 ft. long; leaves short-petioled; stipules large; leaflets $10-20$ pairs, cuneiform, retuse and mucronate at the apex, pubescent; flowers blue, $1 \mathrm{in}$. long, in large axillary racemes; legume oblong, 3-6-seeded. March-May. Introduced and cultivated for winter pastures.

\section{LATHYRUS.}

Like Vicia, excepting that the style is bearded on the side toward the standard.

1. L. Pusillus Ell. Dwarf Vetch. Annual; stem slender, erect or reclining, 10-15 in. long; leaves short-petioled; stipules sagittate; leaflets 2, linear or linear-lanceolate, smooth; peduncles longer than the leaves, 1-2-flowered; flowers purple; calyx teeth nearly equal; legume long and slender, 10-15-seeded. FebruaryMay. On sandy soil, common along fences.

2. L. venosus Muhl. Veiny Vetch. Perennial; stem stout, prominently angled, climbing or reclining, 2-5 ft. long; leaves short-petioled; stipules large, lanceolate; leaflets $5-7$ pairs, broadly ovate, obtuse, mucronate; peduncles nearly as long as the leaves, many-flowered; flowers purple, $\frac{3}{4} \mathrm{in}$. long; calyx teeth very unequal; pod linear, veined, 4-6-seeded. April-June. Shady banks.

\section{BRADBURYA.}

Perennial herbs; stems twining or prostrate; leaves 3 foliate; stipules persistent; flowers large, axillary, racemed or solitary ; calyx short, 5 -toothed, the two upper teeth partly united; standard large, erect, orbicular, emarginate, spurred on the back; stamens monadelphous below; style smooth; legume sessile, linear, many-seeded.

B. Virginiana (L.) Kuntze. Spurred Butterfly Pea. Stem slender, much-branched, rough with hooked pubescence, 2-5 ft. long; leaflets ovate, acute at the apex, rounded at the base, reticulate-veined, stipellate, the upper one long-stalked; peduncles as long as the petioles, often in pairs, 1-4-flowered; flowers pink-purple, 1$1 \frac{1}{2} \mathrm{in}$. broad, short-pediceled; calyx lobes subulate; legume linear, curved, the margin thickened, many-seeded, 4-6 in. long. MaySeptember. Common on dry, sandy soil. 


\section{CLITORIA.}

Perennial herbs; leaves petioled, 3-foliate; stipules persistent; flowers large, on axillary peduncles; calyx tubular, 5-toothed, the two upper teeth partly united; standard large, erect, orbicular, emarginate, not spurred on the back, keel much shorter than the wings; stamens monadelphous below; style hairy; legume stipitate, flattened, few-seeded.

C. Mariana L. Butterfly Pea. Stem erect or twining, smooth, 1-3 ft. long; leaves short-petioled, stipules small; leaflets oblong-lanceolate, pale beneath, stipellate; peduncles shorter than the leaves, 1-3-flowered; flowers large, showy, pale purple, $1 \frac{1}{2}-2 \mathrm{in}$. long; legume 1-1 $\frac{1}{2}$ in. long, $\frac{1}{4}$ in. wide, acute, 3-4-seeded. MayAugust. Dry, sandy soil.

\section{APIOS.}

Perennial twining vines, producing tubers from underground shoots; leaves petioled, odd-pinnate; flowers in dense axillary racemes; calyx 2-lipped, the lateral teeth nearly obsolete; standard broad, reflexed, keel twisted; stamens diadelphous; legume linear, compressed, many-seeded.

A. Apios (L.) MacM. Ground-nut. Stems twining high, juice milky, rootstocks bearing edible tubers; leaves short-petioled; stipules small, soon deciduous; leaflets 5-7, ovate to ovate-lanceolate, acute, slightly stipellate; raceme shorter than the leaves, densely many-flowered, often branching; flowers brownish-purple, about $\frac{1}{2}$.in. long; legume linear, slightly compressed, seeds black, separated by corky tissue. June-August. On damp soil.

\section{GALACTIA.}

Perennial herbs; stems prostrate or climbing, juice often milky; leaves 3 -foliate or pinnate, stipellate; flowers small, in axillary racemes; calyx 4-lobed, the upper lobe largest and about as long as the tube; standard oblong or obovate, reflexed; stamens diadelphous; ovary nearly sessile, style not bearded; legume linear, 2-valved, many-seeded.

1. G. Regularis (L.) B. S. P. Stems prostrate, minutely pubescent, branching, 2-3 ft. long; leaves longer than the petioles; leaf- 
lets oval, rigid, smooth above, pubescent beneath, the upper one long-stalked; racemes shorter than the leaves, 3-6-flowered; flowers large, reddish-purple; style long; legume linear, curved, nearly smooth, 4-6-seeded. June-August. Dry pine barrens.

2. G. volubilis (L.) Britt. Stems twining or prostrate, muchbranched, pubescent or nearly smooth, often several feet in length; leaflets thin, oval to linear-oblong, rounded or emarginate at both ends, smooth or slightly hairy above, paler and pubescent beneath; racemes slender, variable in length, often several times as long as the leaves, single or 2-3 from the same axil; flowers single, or 2-3 together, purplish, about $\frac{1}{2}$ in. long; legume linear, nearly straight, compressed, pubescent. June-July. On dry soil.

\section{RHYNCHOSIA.}

Perennial herbs; stems erect or twining; leaves 1-3-foliate; leaflets mostly resinous-dotted; flowers yellow, in dense axillary or terminal racemes or spikes; calyx 2-lipped, 4-5toothed; standard orbicular or reniform, reflexed; stamens diadelphous; ovary sessile, style slender; legume short, 12 -seeded.

1. R. minima DC. Climbing Rhynchosia. Stem twining, widely branched, tomentose, 3-6 ft. long; leaflets small, orbicular or rhombic, acute, rugose above, dotted beneath; racemes very slender, 2-3 times as long as the leaves; flowers scattered, minute, reflexed; legume strongly curved. May-July. Sandy soil, especially near the coast.

2. R. simplicifolia (Walt.) Wood. Round-leaved Rhynchosia. Stem erect, rough, hairy, 3-8 in. high; leaves pubescent; stipules lanceolate; petioles about as long as the single, orbicular or reniform, erect, pubescent leaflet; racemes dense, often clustered; legume oblong, compressed, 1-2-seeded. April-June. On dry soil.

\section{PHASEOLUS.}

Annual or perennial herbs; stems twining or prostrate; leaves trifoliate; flowers in axillary racemes or clusters; calyx 5-toothed, the two upper teeth somewhat united; standard orbicular, often recurved, keel spirally twisted; stamens diadelphous; legume linear or falcate, few-many-seeded.

P. polystachyus (L.) B. S. P. Wild Bean. Perennial; stem twining or trailing, branching, pubescent, 10-15 ft. long; 
leaflets ovate, acute at the apex, rounded at the base, the terminal one long-stalked; stipules lanceolate, deciduous; racemes axillary, often branched, much longer than the leaves; flower's purple, scattered, pedicellate; legume stipitate, compressed, falcate, 2-3 in. long, 4-6-seeded. June-July. Low woods and thickets.

\section{STROPHOSTYLES.}

Annual or perennial; stems twining or trailing; leaves 3 foliate, stipellate; flowers clustered at the summit of the axillary peduncles; calyx 5-toothed, the two upper teeth more or less united; standard orbicular, keel twisted; stamens diadelphous; pod linear, several-seeded, seeds scurfy or pubescent.

S. helvola (L.) Britt. Trailing Bean. Annual or sometimes perennial; stem slender, trailing or twining, pubescent, 2-4 ft. long; leaflets extremely variable, from prominently 3-lobed to ovate.or oblong-linear; peduncles 2-4 times as long as the leaves; flower's 4-8, sessile, greenish-purple; legume slender, terete, 4-8-seeded. June-September. Common in dry soil.

\section{ERYTHRINA.}

Shrubby or herbaceous; stems armed with prickles; leaves trifoliate; leaflets 3 -lobed; flowers in long terminal racemes; calyx tubular, truncate and oblique at the throat; standard narrowly oblong, erect, wings and keel small; stamens and style exserted; legume stipitate, 2-valved, several-seeded.

E. herbacea L. Coral Plant. Perennial, from a very large woody root; stems erect, smooth, purple, 2-3 ft. high; flowering stems leafless except near the ground; leaves long-petioled; leaflets prominently 3-lobed or sometimes hastate, smooth, dark green, the terminal one long-stalked ; racemes erect, 1-2 ft. long, many-flowered; flowers deep scarlet, 2 in. long; legume nodulose, opening by one suture, seeds bright scarlet. April-May. Light, sandy soil.

\section{GERANIACE E. GERANIUM FAMILY.}

Annual, biennial or perennial herbs with tumid joints; leaves alternate or opposite, simple, more or less lobed or 
divided, stipulate; flowers perfect, regular or irregular; sepals 5 , persistent; petals 5, deciduous; stamens 5, 10 or 15 ; ovary 1, compound, 5-celled, 1-2 ovules in each cell, styles 5 , usually long and persistent, adherent to the elongated receptaele.

\section{GERANIUM.}

Annual, biennial or perennial herbs; leaves palmately lobed or divided, alternate or opposite, petioled; flowers regular; stamens 10 , the alternate ones usually longer; ovary 5 -celled, 5 -seeded, the 5 cells of the ripened ovary separating elastically from the elongated central axis.

1. G. maculatum L. Wild Crane's-bill. Perennial, from a thickened and tuberous rootstock; stems erect, simple or branched, hairy, 1-2 ft. high; leaves palmately 3-7-parted, the lobes incised or toothed, the lower long-petioled, the upper nearly sessile; peduncles long and slender, usually with a pair of leaves at the base of the few-flowered umbel; flowers pink-purple, $1-1 \frac{1}{2}$ in. broad; sepals hairy and awn-pointed; petals entire, pubescent at the base; seeds reticulated. April-May. In damp, open woods.

2. G. Carolinianum L. Carolina Crane's-bill. Annual; stem decumbent or erect, pubescent; leares palmately :3-7-parted, the divisions narrow, toothed, and cut; peduncles short, 2-flowered; flowers pink-purple or nearly white, about $\frac{1}{2}$ in. broad; sepals pubescent, about as long as the emarginate petals; seeds finely reticulated and pubescent. March-April. Common in waste places.

\section{PELARGONIUM.}

Perennial herbs; stems sometimes woody at the base, and somewhat fleshy above; flowers irregular; sepals 5 , the upper one with a slender, nectariferous tube decurrent on the pedicel; petals 5 , the two lower ones smaller; stamens 10 , 3 or 5 of them sterile. A South African genus of which there are several species and many varieties in cultivation, all known by the general name "Geranium."

1. P. zonale L'Hérit. Horse-shoe Geranium. Stem erect, widely branched, woody below; leaves alternate, opposite or sometimes in 3 's, orbicular or reniform, palmately reined, crenate, pubes- 
cent, usually with a dark zone near the middle; flowers in a long peduncled umbel, showy, red or white, often double. Numberless varieties in cultivation.

2. P. Graveolens L'Hérit. Rose Geranium. Stem erect or ascending, densely pubescent, 1-3 ft. high; leaves alternate, palmately lobed or divided, the lobes often finely dissected, revolute at the edges; flowers umbelled, small, light purple with darker veins; whole plant very fragrant. Common in cultivation.

\section{OXALIDACEÆ. SORREL FAMILY.}

Low annual or perennial herbs, with acid juice, root often bulbous; leaves petioled, trifoliate; flowers perfect, regular ; sepals 5, persistent; petals 5, deciduous; stamens 10 , monadelphous at the base, the alternate ones longer; ovary 5celled, several-seeded, styles distinct.

\section{OXALIS.}

Characters of the family.

1. O. violacea L. Violet Wood-sorrel. Perennial, from a bulbous root, acaulescent; leaves long-petioled, leaflets obcordate, sometimes slightly pubescent, often with a dark zone near the middle; scapes usually longer than the petioles, umbellately 4-10-flowered, pedicels slender; flowers violet-purple, nodding; petals obtuse, 2-3 times as long as the sepals; scapes and petioles 4-5 in. long. MayJune. Common in rich woods.

2. O. stricta L. Yellow Wood-sorrel. Annual or perennial; stem slender, decumbent or ascending, branching, 3-12 in. long, pubescent with long hairs; leaves slender, petioled, leaflets broadly obcordate, sensitive; flowers yellow, in small cymes or umbellate clusters on axillary peduncles longer than the petioles; capsule erect, cylindrical, dehiscence loculicidal, often throwing the transversely ridged seeds to a considerable distance. March-December. Common in waste places.

\section{RUTACE E. RUE FAMILY.}

Shrubs or trees; leaves alternate, compound, exstipulate, punctate; flowers perfect or variously imperfect; sepals and 
petals $3-5$ or none; petals hypogynous or perigynous when present; stamens as many or twice as many as the sepals, inserted on the glandular disk; pistils $2-5$, often partially united; fruit a capsule or a samara.

\section{XANTHOXYLUM.}

Trees or shrubs; bark, twigs, and petioles usually prickly; leaves odd-pinnate, punctate with pellucid dots; flowers in axillary or terminal cymes, monœeious or diœcious; sepals and petals $3-5$ or none; stamens $3-5$, hypogynous; pistils 2-5, distinct, sessile or stipitate ; carpels 2 -valved, 1 -2-seeded ; seeds smooth and shining.

1. X. Pterota HBK. Bastard Ironwood. A shrub or small tree; branches crooked and armed with curved, stipular prickles or sometimes smooth; leaflets $7-11$, sessile, obovate, somewhat crenate, dots few, rachis and petiole winged; flowers in axillary, sessile or short-peduncled clusters; sepals, petals, and stamens 4 ; ovaries 2 ; carpels globose, dotted, stipitate. May-June. On rich soil, more common southward.

2. X. Clava-Herculis L. Hercules's Club. A tree 20-40 ft. high; bark very prickly; prickles on the older parts often surrounded by a ring of cork; leaflets $9-21$, ovate-lanceolate, acuminate, crenate, inequilateral, shining above; cymes terminal, appearing before the leaves; flowers small, greenish; sepals and petals 4-5; capsules 2-3, sessile. May-June. In rich, moist woods.

\section{PTELEA.}

Shrubs with smooth and bitter bark; leaves trifoliate; flowers in terminal cymes, polygamous; sepals 3-6, deciduous, much shorter than the petals; stamens $4-5$, longer than the petals and alternate with them; pistillate flowers producing abortive stamens ; ovary compressed, 2-celled; fruit a 2-celled, 2-seeded, broadly winged samara.

P. trifoliata L. Hop-tree. A shrub $4-8$ ft. high; leaves long-petioled, leaflets oval or ovate, acute, obscurely serrate, the lateral ones oblique; cymes compound; flowers greenish; stamens mostly 4 , filaments villous; samara about 1 in. in diameter, wing emarginate, strongly reticulated. May-June. Rocky banks. 


\section{SIMARUBACEÆ. AILANTHUS FAMILY.}

Trees or shrubs, bark bitter, juice milky; leaves alternate, pinnately compound, stipules none; leaflets not dotted; flowers in large, axillary or terminal panicles, regular, diœcious or polygamous; calyx 4-5-toothed or parted, persistent; petals 4-5, deciduous; stamens twice as many as the sepals, hypogynous; ovary of 4-5 distinct or united, 1-seeded carpels; fruit a samara.

\section{AILANTHUS.}

Trees, bark brown, nearly smooth; leaves odd-pinnate; flowers in dense terminal panicles, greenish-white, polygamous or diœcious; sepals and petals 5 ; staminate flowers with 10 stamens; pistillate flowers often bearing $2-3$ stamens ; ovary deeply 2-5-cleft or divided, ovules solitary; samara oblong.

A. glandulosa Desf. Tree of Heaven. Trees, sometimes 60-80 ft. high; leaves odd-pinnate, often 2-3 ft. long; leaflets many, usually opposite, ovate-lanceolate, acuminate at the apex, truncate, oblique and usually glandular-toothed at the base, entire; flowers about $\frac{1}{4}$ in. broad, the staminate disagreeably odorous; samaras with oblong wings, 1 in. long. May-J une. Introduced from China, and naturalized in many places.

\section{MELIACE E. MELIA FAMILY.}

Trees; leaves alternate, exstipulate, pinnately decompound; flowers perfect, in axillary panicles; sepals 5 , short, obtuse; petals 5, 2-3 times as long as the sepals, oblong, obtuse; stamens 10, monadelphous; ovary 5-celled, 10-ovuled; fruit a 5-celled, 5-seeded nut enclosed in a fleshy covering.

\section{MELIA.}

Characters of the family.

M. Azederach L. Umbrella Tree. Trees of medium size with a dense hemispherical head; leaves bipinnate; leaflets ovate, 
acuminate at the apex, rounded at the base, irregularly serrate, glabrous; flowers in large, compound panicles, fragrant, lilac-colored; sepals linear-spatulate, united at the base; petals united below, spreading above; fruit fleshy, enclosing a bony 5-celled nut with one seed in each cell, persistent through the winter. April-May. Introduced from China; common in cultivation.

\section{POLYGALACEÆ. MILKWORT FAMILY.}

Herbs, or rarely shrubs; leaves simple, alternate, opposite or verticillate, exstipulate; pedicels bracted; flowers mostly in spikes or racemes, but sometimes solitary, with a general resemblance to those of the Pea family; sepals 5, persistent, the two lateral longer and wing-like; petals 3 , somewhat united, the middle one longer, usually crested and forming a keel, sometimes with 2 additional scale-like petals; stamens 4-8, monadelphous or diadelphous; ovary superior, compound; fruit a 2 -seeded capsule, seeds usually carunculate and hairy.

\section{POLYGALA.}

Annual, biennial or perennial herbs; leaves alternate, opposite or verticillate, usually small and narrow; flowers usually spiked or racemed, but sometimes solitary, and occasionally on subterranean branches; stamens 8 or sometimes 6 , somewhat united with the petals, usually monadelphous; style simple, curved, club-shaped ; capsule 2-celled, 2-seeded, seeds carunculate and hairy.

1. P. ramosa Ell. Low Yellow Mrlkwort. Biennial; stems single or tufted, erect, simple, 6-12 in. high; leaves alternate, basal leaves spatulate to obovate, obtuse; stem leaves linear-oblong, acute, numerous, somewhat fleshy; flowers bright yellow, in corymbose spikes, wings oblong, acute, crest minute; seeds small, oval, hairy, at least twice the length of the caruncle; plant turning greenishblack in drying. June-September. Open pine barrens.

2. P. lutea L. Orange Milkwort. Biennial; stem simple or occasionally branched, erect, glabrous, 6-12 in. high ; leaves alternate, root leaves spatulate, obtuse, stem leaves oblanceolate, acute; spikes solitary, terminal, oblong, dense ; flowers orange-yellow, wings 
elliptical or ovate, acute, crest minute; seeds obovate, sparsely hairy, a little longer than the lobes of the caruncle. May-August. Moist woods.

3. P. incarnata L. Pink Milkwort. Annual; stem simple or rarely branched, erect, glaucous, $12-18$ in. high; leaves few, alternate, fleshy, linear, sometimes small and scale-like; spike terminal, solitary, slender, densely flowered; flowers pink; petals united into a tube twice the length of the elliptical wings, crest conspicuous; seeds oval, hairy, caruncle spongy. May-August. Dry soil in open fields.

4. P. grandiflora Walt. Showy Milkwort. Perennial or biennial; stems erect or ascending, branched, 6-12 in. high; leaves alternate, elliptical, pubescent; flowers in long terminal and axillary racemes, large, pink or purple, wings large, orbicular, pedicels drooping; seeds oblong, hairy, caruncle small. May-September. Dry, sandy soil.

5. P. polygama Walt. Racemed Milkwort. Biennial; stems erect, simple, numerous, smooth, very leafy; leaves elliptical or the lower spatulate; flowers of two kinds, the showy and perfect purple flowers in loose terminal racemes, and the subterranean inconspicuous but fertile flowers; seeds oblong or ovate, very hairy, twice the length of the caruncle. April-June. Wet pine barrens.

\section{EUPHORBIACE $\AA$. SPURGE FAMILY.}

Trees, shrubs or herbs, with an acrid, and usually milky juice; leaves alternate, opposite or verticillate, petioled or sessile, stipulate or exstipulate; flowers various, often monœcious, petaloid or enclosed in a petal-like involucre; stamens few or many; styles usually 3 , simple or much-divided; ovary usually 3 -celled, sometimes 2 -celled, with 2 ovules suspended in each cell, the carpels at length separating from the central axis.

\section{RICINUS.}

Annual herbs, shrubs or trees; leaves alternate, simple, petioled, palmately lobed; flowers monœeious, in a large oblong spike or panicle, the pistillate flowers at the summit; calyx 3-5-parted; petals wanting; stamens numerous, filaments branched; style short, stigmas 3, 2-parted; capsule spiny, 3-celled, 3-seeded. 
R. communis L. Castor Bean. Annual, becoming a tree in the tropics; stem smooth and glancous, 6-12 ft. high; leaves large, often $1 \mathrm{ft}$. broad, peltate, palmately 6 -12-lobed, the lobes lanceolate, irregularly toothed, petioles long, glandular; stipules large, deciduous; panicles in the forks of the stem, dense; capsules very spiny, $\frac{1}{2}-\frac{3}{4}$ in. long; seeds oval, smooth, mottled. June-October. Introduced from India.

\section{JATROPHA.}

Shrubs or herbs; leaves alternate; flowers monœcious. staminate and pistillate intermixed in the cymes, apetalous: calyx large, white, 5-lobed, corolla-like; stamens numerous, usually monadelphous; ovary usually 3 -celled, 3-seeded, styles 3 , united at the base, several-parted.

J.-stimulosa Michx. Spurge Nettle. Perennial herbs armed with stinging hairs; stems erect, branched, bright green with white lines, 8-15 in. high; leares long-petioled, deeply palmately $3-5$ lobed, the lobes irregularly cut and toothed, often mottled; sepals white, spreading; seeds oblong, smooth, mottled. April-September. In dry woods.

\section{EUPHORBIA.}

Herbs with milky juice; inflorescence cymose; flowers monœcious, without calyx or corolla, usually 1 pistillate and several monandrous staminate flowers are surrounded by cup-like involucre resembling a corolla, and often gland-bearing between its 4-5 lobes; styles 3, each 2-cleft; capsule stipitate, 3-celled, 3-seeded.

1. E. maculata L. Spotted Spurge. Annual; stem prostrate, widely branched, pubescent, 4-12 in. long; leaves opposite, stipulate, short-petioled, oblong, oblique at the base, serrate, usually blotched with purple; involucres small, and mostly near the ends of the branches; glands 4, cup-shaped, their appendages white; capsule ovoid, pubescent, seed 4-angled, faintly wrinkled and pitted. June-October. Very common in waste places.

2. E. corollata L. Flowerivg Spurge. Perennial; stem erect, umbellately branched above, smooth or pubescent, 1-3 ft. high; leares of the stem alternate, those of the branches usually opposite or whorled, rather thick, oval to narrowly oblong, pale beneath, usually slightly pubescent; flowering branches repeatedly forked; involucres terminal and in the forks of the branches, pedun- 
cled; glands 4-5, oblong, green; appendages white and petal-like, showy; capsule erect, seed smooth or faintly pitted. April-November. Common in dry, open woods.

\section{ANACARDIACEE. SUMAC FAMILY.}

Trees or shrubs with resinous, acrid or milky sap; leaves simple, trifoliate or pinnately compound, alternate, exstipulate; flowers perfect or imperfect, small; calyx 3-5-parted, persistent; petals $3-5$ or wanting; stamens as many as the sepals or sometimes twice as many, inserted in the base of the calyx, distinct; ovary free, 1-celled, styles 1-3; fruit a 1-seeded drupe.

\section{RHUS.}

Trees or shrubs; leaves trifoliate or odd-pinnate; flowers in spikes or panicles; calyx mostly 5-parted; petals and stamens 5 ; pistil 1 , sessile, styles 3 , terminal; drupe small, smooth or pubescent.

1. R. Copallina L. Sumac. A shrub or small tree, sometimes 25-30 ft. high; branches tomentose; leaves odd-pinnate, rachis pubescent and wing-margined; leaflets 9-21, ovate-lanceolate, acute at the apex, inequilateral, entire or slightly toothed, smooth and green above, pale and pubescent beneath; panicle often large and spreading; flowers polygamous; drupe red, hairy, acid. JuneAugust. Open woods.

2. R. hirta (L.) Sudw. Staghorn Sumac. A small tree, 20$40 \mathrm{ft}$. high; branches and petioles villous; leaves odd-pinnate, leaflets 17-27, lanceolate-oblong, acuminate at the apex, very obtuse at the base, sharply serrate, smooth above, pale and pubescent beneath; flowers polygamous, in dense terminal panicles; drupes red, with crimson hairs. June-July. Dry hillsides.

3. R. aromatica Ait. Fragrant Sumac. A branching shrub, $2-5 \mathrm{ft}$. high; leaves trifoliate, pubescent when young, smooth when old; leaflets ovate or the terminal one obovate, larger and somewhat 3 -lobed or crenate; flowers diøcious, in single or clustered terminal spikes 1 in. or more in length, appearing before the leaves; drupe red, hairy. March-April. Dry, open woods.

4. R. Radicans L. Poison Vine. Stem a woody vine climbing high by aërial rootlets, or sometimes short and erect; leaves 
petioled, trifoliate, pubescent; leaflets ovate or oval, acuminate, entire or somewhat dentate, often angled or lobed; flowers diøecious, in loose axillary panicles; drupe nearly white, smooth. May-June. Conimon in open woods and along fences. Plant poisonous to the touch.

\section{COTINUS.}

Shrubs or small trees; leaves simple; flowers in large terminal panicles; calyx 5-parted; petals 5 , longer than the sepals; stamens 5 ; styles 3 , lateral; drupe ovoid, inequilateral.

C. Cotinoides (Nutt.) Britt. Sxoke Tree. A small tree; leaves oval or obovate, obtuse at the apex, acute at the base, entire, glabrous or slightly pubescent; flowers in loose and spreading panicles, many of the pedicels abortive but becoming elongated and very plumose; flowers small, perfect; drupe smooth. May-June. Often cultivated for ornament.

\section{CYRILLACEA. CYRILLA FAMILY.}

Small trees or shrubs; leaves often evergreen, alternate; stipules none; flowers perfect, in terminal and lateral racemes; sepals 4-8, persistent; petals as many as the sepals, hypogynous; stamens $5-10$, distinct; ovary $2-5$-celled, $2-5$-ovuled, style entire or 2-4-lobed; fruit dry, 1-5-seeded.

\section{CYRILLA.}

Small trees; branches glabrous; leaves entire, shortpetioled; flowers white, in racemes clustered at the base of the growth of the season; sepals 5, small; petals 5, spreading, deciduous, longer than the sepals; stamens 5 , alternate with the petals; style persistent, 2-lobed; fruit 2-celled, 2 -seeded.

C. RaCemiflora Walt. Leatherwood. A shrub, 10-15 ft. high; branches often in whorls; leares elliptical or ovate-oblong, smooth, entire; racemes many-flowered, 4-6 in. long, pedicels bracted; fruit ovate, about $\frac{1}{12}$ in. long, tipped with the persistent style. June-July. Common on damp soil. 


\section{CLIFTONIA.}

Small trees or shrubs; branches smooth; leaves evergreen, entire, glaucous ; flowers white, racemose; sepals 5-8, minute; petals 5-8, spreading; stamens 10 , those opposite the petals longer; stigma sessile, 3-4-lobed; fruit 3-4-winged, 3-4celled, cells 1 -seeded.

C. Ligustrina Banks. Titi. A small tree; leaves oborate or oblong, glaucous, thick; racemes terminal, 2-4 in. long, manyflowered; flowers white, fragrant; fruit nodding, long-persistent. March-April On damp soil, more abundant southward.

\section{ILICACE E. HOLLY FAMILY.}

Trees or shrubs; leaves simple, alternate, petioled; stipules small or wanting; flowers small, greenish, clustered or solitary in the axils, usually diœcious; calyx 4-9-parted; petals 4-9, somewhat united at the base; stamens inserted in the tube of the corolla and alternate with its lobes; ovary free, 4-9-celled, with a single ovule in each cell; fruit a berry-like drupe, 4-9-seeded.

\section{ILEX.}

Small trees or shrubs; leaves usually coriaceous, often persistent and evergreen; stipules minute ; flowers axillary, 4-9parted, the fertile often solitary and the staminate clustered; fruit a drupe with 4-9 nutlets.

1. I. opaCA Ait. Holly. Trees with smooth, light-colored bark, and hard, very white wood; young twigs pubescent; leaves coriaceous, oval or ovate, margin prickly toothed, dark green and shining abore, paler and sometimes slightly puberulent beneath; peduncles short, bracted; flowers 4-parted, staminate flowers in smali eymes, the pistillate usually solitary; drupes bright red. AprilMay. Damp, sandy soil.

2. I. Decidua Walt. Deciduous Holly. Small trees; twigs smooth; leaves thin, oborate, obtuse or sometimes acute at the apex. crenate, smooth, deciduous; flowers in sessile clusters, 4-6-partod; drupes very numerous, bright red. April-May. On low ground. 


\section{CELASTRACEAE. STAFF-TREE FAMILY.}

Shrubs, sometimes climbing; leaves simple, alternate or opposite, stipulate; flowers small, regular, perfect; calyx 4-5-parted, persistent; petals $4-5$; stamens $4-5$, alternate with the petals and inserted with them on the disk; ovary 1 , carpels $2-5$, styles exserted; fruit a $2-5$-celled pod, seeds ariled.

\section{EUONYMUS.}

Shrubs with 4-angled branches; leaves opposite; flowers in axillary, peduncled cymes, purplish or greenish, small; sepals and petals $4-5$, spreading; stamens as many as the petals, short; ovary 3-5-celled, with 2 ovules in each cell; seeds enclosed in a red, fleshy aril.

1. E. Americanus L. Strawberry Bush. A shrub 3-8 ft. high; leaves short-petioled, ovate to ovate-lanceolate, acute or acuminate at the apex, finely serrulate, smooth or slightly hairy; peduncles axillary, slender, 1-3-flowered; flowers greenish ; capsule 3-5-angled, warty. May-June. In low, shady woods.

2. E. atropurpureus Jacq. Wahoo. A tree-like shrub 10-15 ft. high; leaves oval to ovate, acuminate, finely serrulate, puberulent, petioles $\frac{1}{2}-\frac{3}{4} \mathrm{in}$. long; peduncles slender, 3 -forked, several flowered; flower purplish; capsule deeply 3-4-lobed, smooth. May-June. River banks.

\section{ACERACE $Æ$. MAPLE FAMILY.}

Trees or shrubs, with watery, often saccharine sap; leaves opposite, simple and palmately lobed, or pinnate, exstipulate; flowers regular, mostly polygamous or diœcious, in axillary and terminal cymes or racemes; calyx 4-9-parted; petals as many as the lobes of the calyx or none; stamens 4-12, hypogynous: ovary 2 -celled, styles 2 ; fruit a double samara. 
ACER.

Characters of the family.

1. A. Rubrum L. Red Maple. A small tree with red or purple twigs; leaves simple, broadly ovate, palmately 3-5-lobed or sometimes merely serrate or cut-toothed, acuminate at the apex, rounded or cordate at the base, smooth or pubescent, becoming bright red in autumn; flowers appearing before the leaves on erect, clustered pedicels; petals red or yellow, oblong or linear; fruiting pedicels elongated and drooping; samara red, smooth, wings about an inch long. February-April. Swamps and river banks.

2. A. Saccharum Marsh. Sugar Maple. A large tree; leaves simple, palmately lobed, truncate or cordate at the base, lobes sinuate-toothed and acuminate, pale and slightly pubescent beneath; flowers appearing with the leaves, on clustered, drooping pedicels; calyx bell-shaped, fringed; petals none; samaras smooth, wings about $1-1 \frac{1}{2}$ in. long. April-May. In cold woods, more abundant northward. The sap of this tree is the principal source of maple sugar, and some forms of the tree produce the curled maple and bird's-eye maple used in cabinet making.

3. A. Negundo L. Box Elder. A small tree; leaves opposite, pinnately 3-5-foliate; leaflets ovate, lobed, toothed or entire, pubescent when young; flowers diwecious, appearing from lateral buds before or with the leaves; the staminate on long and drooping pedicels, the pistillate in drooping racemes; samaras smooth, $1-1 \frac{1}{2}$ in. long. March-April. River banks. Often cultivated as a quickgrowing shade tree.

\section{HIPPOCASTANACE}

Trees or shrubs; leaves opposite, long-petioled, palmately compound; flowers showy, polygamous, in terminal panicles; calyx 5-lobed, oblique; petals 4-5, unequal; stamens 5-8, hypogynous; pistil 1, ovary 3-celled, 2 ovules in each cell, style slender; fruit a 1-3-celled, leathery capsule, 1-3-seeded, seeds with a large scar.

\section{ÆSCULUS.}

Characters of the family.

A. Pavia L. Red Buckeye. Shrubs; stems erect, branched, 4-8 ft. high; leaflets usually 5, lanceolate to narrowly oval, acumi- 
nate at both ends, finely serrate, smooth or nearly so; flowers in dense, erect panicles, bright red; stamens rather longer than the petals; fruit nearly smooth. March-May. Common in open woods.

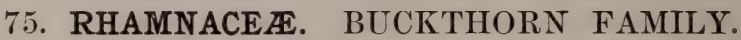

Trees, shrubs or woody vines; stem often thorny; leaves simple, alternate or opposite, stipulate; flowers mostly in axillary or terminal cymes or panicles, small, greenish, perfect or polygamous; calyx 4-5-parted; petals hooded, alternate with the sepals or wanting; stamens as many as the sepals and opposite them, perigynous; style 1, ovary 1-4celled with a single ovule in each cell; fruit a drupe or capsule.

\section{BERCHEMIA.}

Shrubs; stems twining or erect; leaves alternate, prominently pinnate-veined, stipules minute; flowers in axillary or terminal panicles, or rarely solitary; calyx tube hemispherical, 5-lobed; petals 5, sessile, concave, as long as the calyx ; ovary 2 -celled, half-inferior, stigmas 2 ; fruit an oval, 2 -seeded drupe.

B. Scandens (Hill) Trel. Supple-Jack, Rattan-vine. A woody vine, often twining high; older bark yellowish, twigs purple, wood very tough; leaves ovate or oval, acute or obtuse, cuspidate at the apex, rounded at the base, wavy on the margins, green above, pale beneath; flowers in small panicles; drupe purple. May-June. In moist woods and along streams.

\section{RHAMNUS.}

Shrubs or small trees; leaves alternate; flowers in axillary cymes or panicles, perfect, polygamous or diœcious; calyx tube urn-shaped, 4-5-cleft; petals small, often wanting; ovary superior, 3-4-celled, style 3-4-parted; fruit a globose, berrylike drupe with 2-4 smooth or grooved nutlets.

R. Caroliniana Walt. Carolina Buckthorn. A small tree with black bark and rery hard wood; twigs puberulent; leaves 
alternate, prominently veined, elliptical to broadly oval, entire or obscurely serrate, smooth or sometimes pubescent below; petioles slender, pubescent; flowers in axillary, peduncled umbels; petals minute; drupe globose, $\frac{1}{3}-\frac{1}{2}$ in. in diameter, 3 -seeded, seeds smooth. May-June. On river banks.

\section{VITACE E. GRAPE FAMILY.}

Climbing woody vines or diffuse shrubs; stems with joints distinct and enlarged; leaves simple or compound, petioled, stipulate; flowers perfect, greenish, polygamous or diœcious, in cymes; panicles or racemes; calyx minute, usually truncate; petals 4-5, distinct or united; stamens 4-5, opposite the petals, hypogynous or perigynous; ovary 1 , usually more or less immersed in the disk, 2-6-celled, with 2 ovules in each cell, style short or none, stigma 2-lobed; fruit a 1-6seeded berry.

\section{VITIS.}

Climbing woody vines; stems with tumid joints, climbing by tendrils opposite some of the leaves; leaves simple, palmately veined or lobed; stipules small, soon deciduous; flowers mostly polygamous or diøecious; petals often united at the apex and not expanding; stamens inserted between the lobes of the disk; ovary usually 2-celled, 4-ovuled; fruit juicy, 1-4-seeded.

1. V. Labrusca I. Fox Grape. Stems climbing high, often $1 \mathrm{ft}$. or more in diameter; bark shreddy, coming off in long strips, young branches woolly; leaves broadly cordate, more or less deeply 3-5-lobed, mucronate-dentate, very woolly when young, becoming smooth above; panicles of pistillate flowers compact, of staminate flowers looser; fruit about $\frac{1}{2} \mathrm{in}$. in diameter, dark purple or sometimes nearly white. April-May. In rich woods. Many of the cultivated varieties, Concord, Niagara, etc., have been developed from this species.

2. V. Aestivalis Michx. Summer Grape. Stem climbing high; bark shreddy; leaves broadly cordate, 3-5-lobed, the lobes dentate, sinuses rounded, white-woolly when young, often nearly smooth when old; tendrils or panicles opposite 2 out of every 3 
leaves, panicles long and slender; fruit dark blue, small, very acid. April-May. In rich woods.

3. V. Rotundifolia Michx. Muscadine Grape. Stem climbing high; joints short; bark not shreddy; wood very hard, often producing long, aërial roots ; leaves orbicular, cordate at the base, coarsely dentate, nearly or quite smooth; panicle small; fruit few in a cluster, large. May-June. The original form of the Scuppernong grape.

\section{AMPELOPSIS.}

Climbing or diffuse woody plants; leaves simple or pinnately compound; flowers in long-peduncled cymes, polygamous or diœcious; petals 5 , distinct, deciduous ; stamens as many as the petals and opposite them, inserted on the 5 -lobed disk; ovary 2 -celled, 2 ovules in each cell; fruit a berry, not edible.

A. arborea (L.) Rusby. Pepper-vine. Stem diffuse, tendrils often none; leaves bi-pinnate; leaflets small, ovate, irregularly lobed or toothed, nearly or quite smooth ; cymes opposite the leaves, forking; berry small, black. May-July. Common on margins of streams.

\section{PARTHENOCISSUS.}

Woody vines, climbing by tendrils and rootlets; leaves palmately compound; flowers in compound cymes, perfect or polygamous ; petals 5 , distinct, spreading, disk none ; stamens 5 ; ovary 2 -celled, 4 -ovuled; fruit a 1 -4-seeded berry, not edible.

P. quinquefolia (L.) Planch. Virginia Creeper. Stem usually climbing high, but sometimes short and prostrate, often producing many adventitious aërial roots which assist the vine in holding to a support; tendrils usually terminatirg in flat, adhesive disks; leaves palmately 5-foliate; leaflets oval, coarsely and unevenly toothed above, úsually entire below, smooth or slightly pubescent; cymes large and spreading when mature; pedicels red; berries small, dark blue. May-June. Common in rich woods. 


\section{TILIACEAE. LINDEN FAMILY.}

Trees or rarely herbs; leaves simple, alternate; stipules deciduous; flowers in axillary or terminal cymes or panicles, perfect; sepals usually 5 , deciduous; petals 5 or less; stamens many, distinct or united in several groups; style 1 , stigma 4-10-lobed; capsule 2-5-celled, 1-many-seeded.

\section{TILIA.}

Trees with rough, gray bark on the trunk, bark of the twigs smooth, lead-colored; wood white and soft; leaves cordate, usually inequilateral; cymes axillary or terminal, peduncle adnate to a large, prominently veined bract; flowers yellowish-white; sepals 5 ; petals 5 ; stamens many, in 5 groups; ovary 5-celled with 2 ovules in each cell, stigma 5-lobed; capsule 1-celled, 1-2-seeded; peduncle and bract deciduous with the matured fruit, the bract forming a wing by which the fruit is often carried to a considerable distance.

T. PUBESCEns Ait. BAsswood. A tree of medium size; leaves ovate, acuminate at the apex, obtuse and oblique at the base, mucronate-serrate, woolly on both sides or smooth above when old; flowers fragrant, floral bract 2-3 in. long; fruit about $\frac{1}{4}$ in. in diameter. May-June. In rich woods. Bees gather large quantities of nectar from the flowers.

\section{MALVACE E. MALLOIVS FAMILY.}

Shrubs or herbs with mucilaginous juice; leaves simple, alternate, stipulate, palmately veined, usually with stellate pubescence; flowers mostly axillary, on jointed peduncles, perfect, regular, often with a calyx-like involucre; sepals 5, united at the base; petals 5, strongly convolute in the bud; stamens many, inserted in the base of the petals and united into a tube surrounding the pistil; styles distinct or united, ovary several-celled; fruit a several-celled dehiscent pod, or a number of separate 1 -seeded carpels, united around a central axis. 


\section{ALTH冉.}

Biennial or perennial herbs; stems erect, hairy or pubescent; flowers nearly sessile, involucre of 6-9 bracts; anthers at the top of the column; styles many; carpels many, 1 -seeded, indehiscent, separating from the axis at maturity.

A. rosea Cav. Hollyhock. Biennial; stem erect, 3-6 ft. high, hairy; leaves cordate, $5-7$-angled, the lobes irregularly toothed, rugose; flowers large, sessile, white or colored, often double. Summer. Cultivated and often spontaneous.

\section{MALVA.}

Annual, biennial or perennial herbs ; stems smooth or hairy, erect or procumbent; involucel 3-leaved, persistent; flowers peduncled; petals obcordate ; anthers at the top of the column ; styles many; carpels numerous, 1 -seeded, indehiscent.

M. Rotundffolia L. Cheeses. Stem annual or perennial, procumbent; leaves long-petioled, round-cordate or reniform, crenate or crenately lobed; flowers single or clustered; petals white with purple reins, about twice the length of the calyx lobes; styles 10 20 ; carpels broadly reniform. not beaked, pubescent. May-November. Common around dwellings.

\section{CALLIRRHOË.}

Perennial herbs; stem erect, ascending or procumbent; leaves long-petioled, lobed or divided; involucel 1-3-leaved, persistent, or none; flowers perfect; calyx deeply eleft; petals wedge-shaped, entire or crenate at the apex; anthers at the top of the stamen tube; styles many; carpels numerous, 1-seeded, beaked at the apex.

C. Papaver (Cav.) Gray. Poppy Mallow. Stem simple or branched above, erect, rough-pubescent, 12-18 in. high; leaves 3-5parted, the lobes oblong or lanceolate, irregularly toothed; involucel 1-3-leared or none; flowers axillary, solitary, on peduncles sometimes $1 \mathrm{ft}$. long, purple, $1 \frac{1}{2}-2 \mathrm{in}$. wide; petals finely crenate at the apex. May-September. Rich, open woods. 


\section{SIDA.}

Annual or perennial herbs; stem branching, erect or decumbent; leaves mostly undivided; involucel none; flowers small, axillary; calyx angular; anthers at the top of the column; styles 5-15; carpels as many as the styles, mostly 2 -valved and 2 -beaked, separating from each other at maturity, seed 3-angled.

1. S. spinosa L. Prickly Sida. Anuual; stem erect, widely branched above, 12-18 in. high; leaves petioled, ovate or oblong, usually acute at the apex and rounded at the base, serrate, slightly pubescent, lower leaves often cordate; petiole often with a tubercular spine at the base; stipules slender, half the length of the petiole; flowers single or clustered, yellow, $\frac{1}{2}$ in. wide; peduncles shorter than the petioles; carpels faintly reticulated. June-September. Common in waste places.

2. S. Elliottin T. \& G. Elliott's Sida. Perennial; stem erect, slender, with straight branches, rough, 1-4 ft. high; leaves on short petioles, linear-oblong or elliptical, serrate, nearly smooth; stipules setaceous; flowers axillary, yellow, $\frac{3}{4}-1$ in. broad; peduncles longer than the petioles; carpels slightly beaked, strongly reticulated. June-October. Open woods.

\section{ABUTILON.}

Herbs or shrubs; stem erect, branched, usually softly pubescent; leaves long-petioled, cordate or angled; involucel none; flowers axillary; anthers at the top of the tube; ovaries 5 or more, 1-celled, several-seeded; carpels 2-valved, 2-beaked, finally separating from each other and from the central axis.

1. A. Abutilon (L.) Rusby. Velvet Leaf. Annual; stem erect, branched above, velvety-pubescent, 2-5 ft. high; leaves cordate, acuminate at the apex, dentate or nearly entire, the blade about as long as the petiole; peduncles axillary, shorter than the petioles, 1-3-flowered; flowers yellow ; carpels 12-15, strongly spinosebeaked, pubescent, somewhat inflated, 3-seeded. May-September. Introduced from China. Common in fields and waste places.

2. A. striatum L. Abutilon. An erect or spreading shrub 1-4. ft. high; leaves long-petioled, angulate-lobed, acuminate at the apex, crenate, smooth on both sides; peduncles longer than the petioles; 
flowers drooping, red, yellow or white; petals strongly veined; stamen-tube and styles long exserted. A common garden and greenhouse shrub.

\section{MODIOLA.}

Annual or biennial; stems prostrate, diffuse, often rooting at the joints ; leaves cleft or divided ; flowers axillary, peduncled, red; involucel 3-leaved, persistent; anthers at the top of the column; carpels 15-20, transversely 2-celled, with 1 ovule in each cell, beak spine-like, the carpels finally separating from each other and from the axis.

M. Caroliniana Don. Bristly Mallow. Stem pubescent or hirsute, widely branched, 1-2 ft. long; leaves long-petioled, deeply $5-7$-parted, the divisions lobed or toothed; peduncles finally becoming longer than the petioles; petals about the length of the sepals; carpels hispid and prickly along the back. June-September. Waste places.

\section{HIBISCUS.}

Herbs or shrubs; stem erect; leaves dentate, lobed or divided; involucel of many persistent bracts ; flowers showy, on axillary peduncles; filaments united to form a 5-toothed tube which bears the anthers below the summit; stigmas 5 ; ovary 5-celled, many-seeded.

1. H. Accleates Walt. Swamp Hibiscus. Perennial herbs; stems erect, rough-hispid, branched above, 3-6 ft. high ; lower leaves cordate, 3-5-lobed, lobes toothed; upper leaves narrower and nearly entire; leaves of the involucel forked; flowers 3-4 in. wide, on short axillary peduncles; petals yellow with a purple base; capsule pubescent, seeds smooth. June-August. Margins of swamps.

2. H. militaris Cav. Halberd-leaved Mallow. Perennial; stem erect, smooth, 2-4 ft. high; leaves long-petioled, thin, acuminate at the apex, cordate at the base, crenate, many of the lower ones hastate-lobed; stipules deciduous; leaves of the involucel not forked; peduncles shorter than the petioles; flowers pale rose-color with a darker center, 2-3 in. long; calyx enlarged in fruit, enclosing the ovoid capsule, seeds silky. June-September. Along streams and on wet soil. [Among the cultivated plants belonging to this genus are H. Syriacus, the Shrubby Althea, and H. Escuirentus, the garden Okra. Cotton belongs to the nearly related genus Gossypium.] 


\section{THEACEE. TEA FAMILY.}

Trees or shrubs; leaves alternate, simple, pinnately veined, exstipulate; flowers axillary or terminal, showy, perfect; sepals few or many, often unequal in size; petals 4-7 or more; stamens numerous, monadelphous below or in sets opposite the petals; styles $2-5$, distinct or united; capsule 2-5-celled, 2-many ovules in each cell.

\section{CAMELLIA.}

Shrubs or small trees; leaves evergreen, often thick and coriaceous, smooth and shining; flowers axillary or terminal, short-peduncled; sepals many, the inner ones longer; petals white or colored, obovate; stamens many, monadelphous below; styles united, stigmas 3-5; fruit a dry, 3-5-celled capsule.

1. C. Japonica L. Camellia. Shrubs or small trees; leaves short-petioled, thick and leathery, dark green, shining, ovate, acuminate, serrate; flowers mostly terminal, solitary; petals red or white; stamens very numerous, often many of them transformed into petals. February-April. Introduced from Japan, and hardy in the southern section.

2. C. viridis. Tea. A branching shrub 2-6 ft. high; leaves petioled, lanceolate-oblong; acute, serrate, smooth and shining; flowers axillary, white, fragrant; petals twice as long as the sepals; capsule 2-5-celled, 2-5-seeded, seeds nearly black, as large as peas. March-June. Introduced from China and often cultivated.

\section{STUARTIA.}

Shrubs; leaves alternate, deciduous ; flowers large, on short axillary peduncles; sepals 5-6, silky, lanceolate; petals 5-6, obovate, crenulate, silky; stamens monadelphous below, inserted in the base of the corolla; styles 1 or -5 , ovary 5 -celled, 2 ovules in each cell; fruit an ovoid, woody capsule.

S. Malachodendron L. Round-Fruited Stuartia. Shrubs, 6-12 ft. high; twigs pubescent; leaves short-petioled, oval, thin, finely serrulate, slightly pubescent; flowers $2-3$ in. wide, on very 
short peduncles; sepals roundish, silky-pubescent, united below; petals white, minutely pubescent below, round-obovate; filaments purple, anthers blue; style single, 5-lobed; capsule globose, pubescent, seeds not margined. April-May. Shady woods.

\section{HYPERICACEZE. ST. JOHN'S-WORT FAMILY.}

Herbs or shrubs; leaves simple, opposite, exstipulate, pellucid-punctate or black-dotted; flowers solitary or cymose; sepals 4-5, persistent, often unequal; petals 4-5, deciduous, usually oblique; stamens hypogynous, mostly numerous, often united at the base into 3 or 5 sets; styles 1 -several, distinct or united; capsule 1-celled with parietal placentæ, or severalcelled by the meeting of the placentæ in the axis, seeds very numerous, small.

\section{ASCYRUM.}

Small shrubs with brown shreddy bark and smooth 2-edged branches; leaves sessile; flowers mostly solitary, yellow; sepals 4 , the outer pair orbicular or cordate, the inner narrow; petals 4 , oblique; stamens many, distinct or slightly united at the base; styles 2-4, ovary 1-celled with 2-4 parietal placentæ; capsule 2-4-valved.

1. A. stans Michx. St. Peter's-wort. An erect, branching shrub, 2-3 ft. high ; leares oval or oblong-oval, sessile, obtuse, entire; pedicels 2-bracted below the middle; outer sepals orbicular-cordate, the inner lanceolate; petals obovate, longer than the sepals; capsule shorter than the sepals. June-September. Cornmon on pine barrens.

2. A. hypericoides L. St. Andrew's Cross. Stems branching, low and decumbent, 5-12 in. long; leaves oblong or narrowly obovate, narrowed to the sessile base; pedicels 2-bracted above the middle; outer sepals oval, obtuse, double the length of the pedicel, inner sepals very small; petals oblong, approximate in pairs; styles 2 ; capsule as long as the sepals. June-September. On dry, sandy soil.

\section{HYPERICUM.}

Herbs or shrubs; leaves opposite, sessile or short-petioled, punctate or black-dotted; flowers yellow, mostly cymose; 
sepals 5, equal or nearly so; petals 5, oblique; stamens numerous, distinct or united in sets; styles $3-5$, distinct or united, ovary 1- or sometimes 3-5-celled.

1. H. maculatum Walt. Spotted St. John's-wort. Perennial from a woody base; stem erect, branched above, 2-3 ft. high; leaves oval, obtuse at the apex, clasping at the base, conspicuously black-dotted; cymes large, many-flowered, pedicels short; sepals lanceolate, acute ; petals twice the length of the sepals, black-dotted; stamens numerous, in 3-5 sets; styles 3 , twice as long as the ovoid, 3-celled ovary. June-August. Dry pine barrens.

2. H. mutilum L. Dwarf St. John's-wort. Annual; stem erect, 4-angled, branched above, 9-15 in. high; leaves oblong or ovate, obtuse at the apex, clasping at the base, 5-nerved; cymes many-flowered, bracted, branches slender; sepals lanceolate, about the length of the petals; stamens $6-15$, distinct; styles separate; capsule green, ovoid, 1-celled. June-August. Common on low ground.

\section{SAROTHRA.}

Annual; stem erect, branched above; leaves opposite, linear or subulate; flowers scattered on the branches, small, short-pediceled or sessile; sepals 5 , regular; petals 5 ; stamens 5-10; styles 3, distinct, ovary 1-celled; seeds striate.

S. Gentianoides L. Prne-weed. Stem with numerous erect, wiry branches, $9-18 \mathrm{in}$. high; leaves minute, bract-like; flowers sessile, yellow; sepals linear, half the length of the acute, purple capsule. May-August. In old fields on sandy soil.

\section{CISTACEE. ROCK-ROSE FAMILY.}

Low shrubs or herbs; leaves simple, alternate or opposite; flowers solitary or clustered, regular, usually perfect; sepals 5 , the 2 outer ones smaller and bract-like, persistent; petals 5 , rarely wanting; stamens few or numerous, distinct, hypogynous ; style 1, stigma entire or 3-lobed ; ovary 1-celled, severalseeded. 


\section{HELIANTHEMUM.}

Herbs, somewhat woody at the base; stem branching; flowers often of 2 forms, the one with large and showy petals, the other small and inconspicuous, both perfect; stamens few or numerous; style short or wanting, stigma capitate or 3-lobed.

1. H. Carolinianum Michx. Carolina Rock-rose. Perennial from a woody base; stems villous, $6-12$ in. high; leaves shortpetioled, lanceolate, or the lower obovate, acute, denticulate, margins not revolute; flowers mostly terminal, all large and petaliferous, yellow, 1 in. wide; stamens many; capsule many-seeded. NarchApril. Dry, sandy soil.

2. H. Canadense (L.) Michx. Frost-weed. Perennial from a woody base; stems hoary-pubescent, erect, widely branched, 10-20 in. high; leaves lanceolate or elliptical, downy, or smooth above, entire, margin revolute; flowers axillary, of 2 kinds, the larger $1 \mathrm{in}$. wide, solitary, the smaller appearing later, apetalous, clustered; sepals acute, pubescent, the inner larger, much longer than the depressed-globose capsule. April-June. Dry, sterile soil.

\section{VIOLACEAE. VIOLET FAMILY.}

Herbs, often acaulescent; leaves simple, basal or alternate, stipulate; flowers usually solitary, perfect, irregular; sepals 5 , persistent; petals 5 , irregular, the lower one usually saccate or spurred; stamens 5 , hypogynous, connivent; style single; ovary 1-celled, with 3 parietal placentæ, 3-valved, many-seeded.

\section{VIOLA.}

Annual or perennial, acaulescent or with a decumbent stem ; leaves nearly entire or much divided; flowers single, longpeduncled, oblique; sepals prolonged at the base; lower petal spurred; filaments of the two upper stamens prolonged above the anthers; style usually bent and stigma beaked; many species producing fertile, apetalous flowers on short peduncles late in the season. 
1. V. palmata L. Early Blue Violet. Acaulescent from a thick and scaly rootstock; leaves long-peduncled, broadly cordate in outline, the earlier nearly entire, the later with the lower part deeply lobed or cleft, the upper part crenate or dentate ; petioles and peduncles pubescent, peduncles becoming longer than the petioles; flowers blue; lateral petals and style bearded; apetalous flowers on reflexed peduncles abundant late in the season. February-June. Common in dry woods.

2. V. obliqua Hill. Meadow Violet. Acaulescent from a thick rootstock; leaves on long and slender petioles, not divided, ovate to broadly reniform, apex mostly acute, the sides rolled inward when young, crenate or dentate; flowers blue or sometimes white; lateral petals bearded, often with darker veins; stigma beakless. February-June. Common on low ground.

3. V. pedata L. Bird's-foot Violet. Acaulescent from a thick, erect rootstock; smooth or nearly so; leaves orbicular or reniform, deeply parted into numerous linear or narrow lobes which are often toothed at the apex; peduncles longer than the petioles, bracted; flowers mostly blue, the upper petals sometimes darker, whole flower occasionally white; petals not bearded; apetalous flowers none. March-May. On dry hills.

4. V. odorata L. English Sweet Violet. Tufted from stoloniferous rootstocks, smooth or somewhat pubescent; leaves round-cordate, crenate; peduncles bracted, longer than the petioles; flowers blue or sometimes white, very fragrant; petals not bearded; apetalous flowers abundant late in the season. February-May, or all the winter. Common in cultivation.

5. V. Primulefolia L. Primrose-leaved Violet. Rootstock slender, producing numerous long runners rooting at the joints; leaves ovate, crenate, smooth or hairy, decurrent on the long petiole; peduncles longer than the leaves; flowers white; petals often acute, the lower ones bearded and veined with purple. March-June. On low ground.

6. V. Hastata Michx. Halberd-Leaved Violet. Perennial; stem smooth or hairy, simple, ascending or erect, 6-12 in. high; leaves deltoid-ovate, often hastate-lobed, crenate; stipules small, entire; flowers yellow, on axillary peduncles; lateral petals bearded, the lower with purple veins. April-May. Shaded hillsides.

7. V. tricolor L. Pansy. Annual; stem smooth or hairy, angled, diffuse; leaves ovate to spatulate, irregularly crenate-dentate; stipules large, foliaceous, toothed or pinnatifid; flowers of many colors. Common in gardens.

8. V. tenella Muhl. Field Pansy. Annual; stems slender, glabrous, angled, erect, 5-8 in. high; leaves petioled, mostly orbicular, crenate or dentate; stipules large, toothed and pinnatifid; flowers 
small, long-peduncled, dark purple and yellow. March-May. Common in dry, cultivated ground. Very similar to the cultivated Pansy, but much smaller.

\section{PASSIFLORACEA. PASSION-FLOWER FAMILY.}

Shrubs or herbs, climbing by axillary tendrils; leaves alternate, simple, mostly 3-lobed ; Howers axillary, on jointed peduncles, solitary or few together, perfect, regular, often showy; calyx tube 4-5-lobed, persistent; petals usually 5, inserted on the throat of the calyx tube which is fringed with a crown of 1-3 rows of long and slender filaments; stamens 5, their filaments united, and enclosing the stipe of the ovary; styles 1-5, ovary with $3-5$ parietal placentæ; seeds numerous, fruit fleshy.

\section{PASSIFLORA.}

Characters of the family.

1. P. incarnata L. Passion-flower. Perennial; stem often 20-30 ft. long, somewhat angled or striate, smooth below, pubescent above; leaves broadly cordate, palmately 3-5-lobed, the lobes acute, finely serrate, usually cordate at the base; petiole bearing 2 oval glands near its summit; flowers $2-3$ in. wide, solitary; peduncles 3-bracted, longer than the petioles; calyx lobes with a small horn-like appendage on the back near the apex, white within; petals and crown purple and white; fruit yellow, about the size and shape of a hen's egg, edible; seeds with a pulpy aril. May-July. Common along fence rows and embankments.

2. P. lutea L. Yellow Passion-flower. Perennial; stem slender, glabrous, 6-10 ft. long; leaves broadly cordate, 3-lobed at the summit, entire, often mucronate; stipules small; petioles without glands; peduncles longer than the leaves, usually in pairs; flowers greenish-yellow, $\frac{1}{2}-\frac{3}{4}$ in. wide; fruit purple, oval, $\frac{1}{2}$ in. long. May-July. Woods and thickets.

\section{CACTACE⿸⿻ CACTUS FAMILY.}

Succulent shrubs; stems globose, flattened or terete, ridged and tubercled, often jointed and usually spiny; leaves none, 
or very small and fleshy; Howers showy, solitary, sessile; sepals and petals many and similar, adherent to the 1-celled ovary; stamens numerous, inserted on the base of the petals; style single, stigmas many; fruit a fleshy, many-seeded berry.

\section{OPUNTIA.}

Stems in flattened or cylindrical joints ; leaves small, fleshy, on the upper parts of the younger joints, with a tuft of hairs and a few strong spines in the axils; sepals and petals not united to form a tube above the top of the ovary; stamens very numerous; style longer than the stamens, 3-8-divided; fruit bristly.

1. O. Opuntia (L.) Coult. Prickly Pear. Prostrate or ascending; stems with oval or obovate, flattened joints ; leaves soon deciduous; spines few, solitary; flowers from the edges of the joints, near the summit, yellow, often variegated with red, 2-3 in. wide; fruit obovoid, purple, edible, 1-1 $\frac{1}{2}$ in. long. June-August. Dry, barren soil.

2. O. Pes-Corvi LeC. Crowfoot Cactus. Prostrate or ascending; joints cylindrical or slightly flattened, 1-3 in. long, separating easily; spines in pairs, unequal; sepals and petals 8-12; stigmas 4 ; fruit small, fleshy, bristly, 1-4-seeded. May-June. On sandy soil, more common along the coast.

\section{THYMELEACE $Æ$ MEZEREON FAMILY.}

Shrubs or trees, with acrid sap; bark tough and fibrous; leaves simple, alternate, exstipulate; flowers regular, perfect, in axillary clusters; calyx tube cylindrical, 4-5-toothed or entire; petals none; stamens 8 in 2 rows, inserted on the calyx, exserted, the alternate ones longer; ovary superior, 1-celled, 1-ovuled, style long, stigma capitate; fruit a drupe.

\section{DIRCA.}

Shrubs; bark very tough, with interwoven fibers; leaves deciduous, short-petioled; flowers in small clusters from buds on shoots of the previous season, and protected by hairy 
scales; branches often developed later from the same buds; peduncles short, $2-4$-flowered; calyx tube entire or slightly 4 -toothed; stamens and style long exserted; drupe small, oval, red.

D. palustris L. Leatherwood. A branching shrub, 2-5 ft. high; leaves oblong or obovate, obtuse at the apex, rounded at the base, entire, pubescent when young, becoming smooth with age; peduncles short, 3-flowered; flowers light yellow, bud-scales 3-4, oval, downy; drupe $\frac{1}{3}-\frac{1}{2}$ in. long. February-March. Banks of streams.

\section{LYTHRACEÆ. LOOSESTRIFE FAMILY.}

Trees, shrubs or herbs; leaves opposite or alternate; stipules none; flowers solitary or clustered; calyx tube enclosing the ovary and sometimes coherent with it, 4-8-toothed; petals as many as the calyx lobes or none, inserted on the calyx with the few or many stamens; ovary 1-6-celled, style 1, stigma capitate or 2-lobed; fruit capsular or baccate, usually many-seeded.

\section{LAGERSTREMIA.}

Shrubs or small trees; bark smooth and exfoliating.in longitudinal plates; branches winged; leaves alternate; flowers in large terminal panicles; calyx tube bell-shaped; stamens numerous, exserted.

L. Indica L. Crape Myrtle. Small trees, trunk often greatly enlarged at the surface of the ground; leaves oval or oblong, rounded at each end, mucronate at the apex, thick, entire, smooth; flowers pink, purple or white; petals 6 , large, crisped, claw slender; style long exserted; fruit a many-seeded capsule. April-June. Introduced from India.

\section{PUNICA.}

Shrubs or small trees; leaves opposite; calyx tube adherent to the ovary; stamens very numerous, unequal; style long; fruit a several-celled, many-seeded berry. 
P. Granatum. Pomegranate. Erect, branching shrubs; leaves lanceolate or ovate, acute at the apex, rounded at the base, entire; flowers solitary, short-peduncled; calyx and corolla bright red; calyx lobes 5, triangular, persistent; petals 5, oval, erect; fruit globose, crimson, 3-4 in. in diameter, 3-celled below and 5-celled above, edible; seeds many, surrounded by a pulpy aril having a pleasant acid taste. May-June. Introduced from Europe.

\section{MELASTOMACE E. MEADOW-BEAUTY FAMILY.}

Perennial herbs; leaves simple, opposite, 3-9-ribbed, exstipulate; flowers in terminal cymes; calyx tube urn-shaped, constricted at the neck, 4-lobed, persistent; petals 4, inserted in the throat of the calyx tube, oblique; stamens usually twice the number of the petals, anthers often long, curving upward and spurred at the base; ovary superior, 4-celled, placentæ central, style single, bent to one side; fruit a many-seeded, 4-celled capsule.

\section{RHEXIA.}

Characters of the family.

1. R. Mariana L. Deer-grass. Stem erect, branched, terete or 6-angled, bristly, 1-2 ft. high; leaves lanceolate or linear-oblong, short-petioled, acute, 3-nerved, bristly on both sides, ciliate-serrate; flowers purple, $1 \frac{1}{2}-2$ in. wide; calyx tube bristly or nearly smooth, the neck as long as the globose portion; petals rounded; anthers curved, saccate at the base. June-September. In wet, sandy soil.

2. R. Virginica L. Meadow-beauty. Stem erect, nearly simple, hairy or bristly, 4-angled, 10-15 in. high; leaves oval or ovate-lanceolate, sessile, 3-5-nerved, both surfaces with scattered hairs, bristly serrate; flowers bright purple, $1-1 \frac{1}{2}$ in. wide; calyx bristly, the neck shorter than the globose portion; petals rounded, usually truncate at the apex; anthers curved, spur small. JuneSepternber. In swamps.

3. R. Glabella Michx. Smooth Meadow-beauty. Stem erect, mostly simple, smooth, 2-3 ft. high; leaves lanceolate or elliptical, sessile, entire or faintly serrate, thick, smooth, and glaucous; flowers bright purple, $1 \frac{1}{2}-2 \mathrm{in}$. wide; calyx often glandular-hispid; petals oborate; anthers long and curved. June-August. Low pine barrens. 
4. R. Lutea Walt. Yellow Meadow-beauty. Stem erect, widely branched, 4-angled, bristly, 10-15 in. high ; lower leaves spatulate or obovate, the upper lanceolate and acute, all nearly smooth, margin bristly serrulate; flowers numerous, about 1 in. wide; calyx tube short, smooth, much constricted, the lobes cuspidate; petals yellow; stamens straight, erect. June-August. Damp woods.

\section{ONAGRACE E. EVENING PRIMROSE FAMILY.}

Herbs, or rarely shrubs; leaves simple, opposite or alternate, exstipulate but sometimes with basal glands; flowers solitary, spiked or racemed; calyx adherent to the ovary, and often prolonged into a tube beyond it, usually 4-lobed; petals distinct, usually 4 , sometimes none; stamens 4 or 8 , inserted with the petals at the top of the calyx tube; ovary 1-6-celled, style 1, simple or 4-parted; fruit a capsule or berry, dehiscent or indehiscent, 1-many-seeded.

\section{LUDWIGIA.}

Perennial herbs, often stoloniferous; leaves simple, opposite or alternate, entire; flowers axillary or terminal; calyx tube not prolonged beyond the ovary, cylindrical or obconic, usually crowned with 4 persistent lobes; petals 4 , roundish or obcordate, often wanting; stamens 4 , short; style capitate or 4-lobed; capsule 4-5-celled, winged or angled, many-seeded.

1. L. alata Ell. Winged Ludwigia. Stem erect, smooth, simple or branched, winged, often stoloniferous, 2-3 ft. high ; leaves alternate, oblanceolate or almost linear, nearly or quite sessile, obscurely dentate; flowers axillary or in terminal spikes, small, sessile; calyx glabrous; petals none; capsule cubical or obpyramidal, angles winged; seeds ovoid, faintly pitted. June-September. On marshy ground.

2. L. hirtella Raf. Hairy Ludwigia. Stem erect, slender, simple or sparingly branched, hairy, 2-3 ft. high; leaves alternate, lanceolate or oblong, obtuse at the apex, sessile and rounded at the base, hirsute; flowers axillary, on 2-bracted pedicels; calyx lobes erect or spreading, lanceolate, acute, about half as long as the yellow, obovate petals, and longer than the cubical, hairy capsule. JuneSeptember. In flat pine barrens. 
3. L. alternifolia L. Rattle-box. Stem erect, much branched, smooth or pubescent, 2-3 ft. high; leaves alternate, shortpetioled, lanceolate or elliptical, acute; flowers axillary, or the upper ones somewhat racemed, on short 2-bracted peduncles; calyx lobes ovate, acute, spreading, deciduous, about as long as the obovate, yellow, caducous petals; capsule smooth, cubical, angles slightly winged. June-September. In swamps.

\section{JUSSI $\mathbb{E A}$.}

Perennial herbs; stems erect or creeping, smooth; leaves alternate, petioled or sessile; flowers solitary, axillary, white or yellow; calyx tube not prolonged beyond the ovary, the limb 4-6-lobed, persistent; petals 4-6; stamens $8-12$, in 2 rows, inserted with the petals; stigma 4-6-lobed; capsule elongated, angled, 4-6-celled, many-seeded.

J. DeCurrens (Walt.) DC. Upright Jussiza. Stem erect, smooth, angled, branched above, 1-3 ft. high; leaves alternate, lanceolate, entire, smooth, acute at the apex, sessile and decurrent on the stem; flowers nearly sessile; calyx lobes 4 , lanceolate, acuminate; petals 4, yellow, obovate, a little longer than the calyx lobes; stamens 8; capsule oblong-clavate, 4-angled, many-seeded. JuneSeptember. On wet soil.

\section{ONAGRA.}

Annual or biennial herbs; stems erect; leaves alternate, toothed, sessile or short-petioled; flowers in terminal, leafy spikes, yellow, nocturnal; calyx tube prolonged beyond the ovary, the lobes narrow, becoming reflexed and deciduous; petals 4 ; stamens 8 , equal in length; style elongated, stigma 4-parted; capsule 4-celled, 4-angled, many-seeded.

O. Biennis (L.) Scop. Evening Primrose. Biennial, or sometimes annual; stem stout, erect, branched above, hirsute or nearly smooth, 2-6 ft. high; leaves oblong-lanceolate, acute at the apex, sessile or narrowed into a petiole below, wavy-denticulate, smooth or pubescent; flowers sessile, bright yellow or nearly white, opening in the evening, $1 \frac{1}{2}-2$ in. broad; calyx tube slender, 2-3 in. long; petals obovate, retuse; capsule oblong, narrowed at both ends, rough, hairy, obtusely 4 -angled, $\frac{3}{4}-1$ in. long. June-October. Common on dry soil. 


\section{KNEIFFIA.}

Annual, perennial, or sometimes shrubby; leaves alternate, usually narrow; flowers in terminal spikes or racemes, yellow, diurnal; calyx tube prolonged beyond the ovary, the lobes often united at the apex, finally becoming reflexed; petals 4 ; stamens 8 , the alternate ones longer; style slender, stigma 4-parted; capsule sessile or peduncled, clavate, 4-angled, seeds many.

1. K. linearis (Michx.) Spach. Narrow-leaved Primrose. Biennial or perennial; stem erect or ascending, slender, simple or branched, smooth or pubescent, 12-18 in. high; lower leaves obovate, the upper linear or linear-spatulate, entire or slightly toothed; racemes terminal, short, leafy, many-flowered; flowers yellow, 1-1 $\frac{1}{2}$ in. broad; calyx pubescent, the tube $\frac{1}{2}$ in. long; petals obcordate; capsule narrowly obovate, prominently 4 -winged with 4 interınediate ribs, shorter than the pedicel. April-June. On dry, sandy sọil.

2. K. fruticosa (L.) Raim. Sundrops. Perennial; stem erect, simple or branched, more or less pubescent; leaves lanceolate, sessile or short-petioled, wavy-denticulate on the margins; racemes terminal, finally much elongated; flowers yellow, diurnal, $1 \frac{1}{2}-2$ in. broad; calyx tube longer than the ovary; petals obcordate; capsule oblong-clavate, sessile or nearly so, prominently 4 -winged with intermediate ribs, longer than the pedicel. June-September. In old fields.

\section{GAURA.}

Annual, biennial or perennial herbs, sometimes woody at the base; leaves alternate, sessile; flowers in terminal spikes or racemes; calyx tube slender, prolonged beyond the ovary, 4-lobed, the lobes reflexed; petals 4, long-clawed, unequal; stamens 6-8, usually turned to one side; style declined, stigmas 4-lobed, ovary 3-4-celled; fruit a 3-4-angled capsule, mostly 1-celled, 3-4-seeded.

1. G. biennis L. Biennial Gaura. Biennial; stems erect, widely branched, soft-pubescent, $3-8 \mathrm{ft}$. high ; leaves oblong-lanceolate or elliptical, acuminate, wavy-denticulate, pubescent or becoming smooth above; flowers sessile in long-peduncled spikes; petals white, fading to pink ; fruit sessile, narrowly ovoid, obtusely 4-angled, pubescent. June-September. On dry soil, more coinmon northward. 
2. G. Michadxin Spach. Micilacx's Gacra. Stem erect, slender, paniculately branched above, pubescent when young, becoming smooth or glabrous, 2-4 ft. high; leaves very numerous, broadly linear, toothed, wavy-margined; racemes long-peduncled, few-flowered; flowers on slender pedicels, white, fading to pink; fruit ovoid, obtuse, sharply 4-angled; capsule about as long as the pedicel. June-August. Dry pine barrens, more common southward.

\section{FUCHSIA.}

Shrubs ; leaves opposite or sometimes in 3's ; flowers axillary, long-peduncled ; calyx tube prolonged beyond the ovary, limb 4-parted, colored and corolla-like, deciduous; petals 4; stamens 8 , exserted, unequal ; style long and exserted; disk glandular, 8-furrowed ; fruit a many-seeded berry.

F. coccinea Curt. Fuchisia. Stem erect, widely branched; leaves smooth, oval to cordate, denticulate, thick, smooth; flowers drooping; calyx red or white; corolla purple, red or white; stamens and style long, exserted, filaments usually colored; fruit oval, somewhat 4-sided. A common house-plant, introduced from Brazil.

\section{ARALIACEÆ. GINSENG FAMILY.}

Herbs, shrubs or trees; leaves compound; flowers in umbels which are often paniculate, polygamous or sometimes perfect ; calyx tube adherent to the ovary, its limb 5-toothed or truncate; petals usually 5 , small, flat, and spreading, inserted on the summit of the calyx tube; stamens as many as the petals and alternate with them; styles $2-5$; fruit a 1-several-celled drupe or berry.

\section{ARALIA.}

Herbs, shrubs or trees; leaves alternate, pinnately decompound, base of the petiole sheathing; umbels in cymes or panicles; flowers small, white or greenish, on jointed pedicels ; calyx 5-toothed or truncate; petals, stamens and styles 5; fruit usually a 5 -seeded berry.

1. A. spinosa L. Hercules's Club. A small tree, stem, branches and petioles with very numerous, large prickles; leares 
long-petioled, bipinnately compound, leaflets stalked, ovate, acuminate at the apex, obtuse and inequilateral at the base, serrate, thick, smooth and shining above, glaucous and slightly pubescent beneath, often with smaller leaflets intermixed; umbels in very large, terminal, hoary or pubescent panicles; flowers small, white; styles distinct; fruit ovoid, 5-lobed, black, about as long as the pedicel. June-August. In swamps, often cultivated.

2. A. RACEmosi L. Spikenard. Perennial herb; root thick, aromatic; stem erect, smooth, widely branched, $3-5 \mathrm{ft}$. high ; leaves ternately decompound, leaflets cordate, acuminate at the apex, sharply and doubly serrate; umbels in large panicles ; flowers small, greenish ; styles united below; fruit dark brown or purple, globose. JuneJuly. In rich woods.

3. A. nudicaulis L. Sarsaparilla. Perennial herb; roots very long, somewhat fleshy, aromatic; stem very short or none; leaf solitary from a sheathing base, petioled, 6-12 in. long; ternately divided, the divisions 3-5-pinnate; leaflets oval or ovate, acuminate, finely and sharply serrate, smooth above, often pubescent below; scape nearly as long as the petiole, usually bearing 3 short-peduncled umbels ; flowers greenish ; styles distinct; fruit globose, black. MayJune. In rich woods.

\section{PANAX.}

Perennial herbs; root fleshy, aromatic; stem naked, with a whorl of palmately compound leaves and a single umbel of greenish flowers at its summit; calyx minutely 5-toothed; petals and stamens 5 ; styles $2-3$; fruit a drupe-like berry with 2-3 seeds.

P. quinquefolium L. Ginseng. Root fusiform, often forked, $3-5$ in. long; stem erect, glabrous; leaflets 5-7, stalked, the upper longer, oval or obovate, acuminate at the apex, sharply and unevenly serrate; umbel 5-15-flowered, pedicels short, peduncles 1-2 in. long; flowers small, greenish-yellow; styles 2 ; berry compressed-globose, bright red, 2-3-seeded. June-August. In rich, shady woods.

\section{UMBELLIFERÆ. PARSLEY FAMILY.}

Herbs; stems usually hollow and grooved; leaves alternate, simple, compound or decompound, base of the petiole usually sheathing; flowers small, in simple, compound or decompound umbels, or sometimes in close heads ; base of the umbel usually 
subtended by an involucre, and the divisions of the compound umbel by involucels; calyx tube adnate to the ovary, truncate or minutely 5 -toothed; petals and stamens 5 , inserted in the disk at the top of the calyx tube; ovary 2-celled, styles 2 , distinct; fruit of 2 earpels which separate from each other at maturity, each carpel with 5 longitudinal ribs, and often 4 additional ribs between them; oil tubes are usually present under or between the ribs. [The flowers are all so much alike, and the foliage varies so widely in species of the same genus, that the characters for classification depend almost wholly upon minute structural peculiarities of the fruit, making the family an exceedingly difficult one for study. There are about 27 genera and 51 species in our region, but most of them flower late in the season.]

\section{DAUCUS.}

Annual or biennial herbs; leaves pinnately decompound, the divisions finely dissected and linear; umbels compound, the outer rays longer; flowers white or pink, involucre of pinnately dissected leaflets, involucels bract-like, entire or toothed; calyx teeth minute or wanting; petals obovate; carpels obovate, ribs 9 , prickly or bristly, oil tubes 6 .

D. pusillus Michx. Wild Carrot. Stem erect, simple or with a few branches above, rough-hispid, 1-2 ft. high ; leaves twice pinnate, divisions linear; umbels long-peduncled, markedly concave on the top; bristles of the fruit barbed or hooked, adhering readily to hair and clothing. June-July. On dry, sterile soil, often a troublesome weed.

\section{PASTINACA.}

Biennial or sometimes annual, from a straight, fleshy root; stem erect, widely branched above; leaves pinnate; umbels compound, involucre and involucels none; flowers yellow; calyx teeth none; fruit flattened dorsally ; lateral ribs winged, the others inconspicuous. 
P. sativa L. Parsip. Root long-conical, fleshy; stem erect, branched, pubescent above, glabrous below, 2-5 ft. high; lower leaves long-petioled, pinnate, the divisions sessile, acute or oval, irregularly incised or lobed, sharply and unevenly serrate, upper leaves similar but much smaller; umbels numerous, compound, 7-15-rayed, rays slender, umbellets 5-10-rayed ; fruit smooth, broadly oval, nearly as long as the pedicels, lateral ribs and oil tubes prominent, intermediate ribs reduced to slight ridges. JuneAugust. Escaped from cultivation and sometimes a troublesome weed; root reputed to be poisonous in its wild state.

\section{THASPIUM.}

Perennial herbs; stem erect; leaves 1-2-ternately compound; umbels compound, involucre and involucels usually wanting; flowers yellow or purple; calyx teeth small, acute ; fruit ovoid or oblong, somewhat laterally compressed; carpels smooth, strongly ribbed, oil tubes between the ribs.

T. barbinode (Michx.) Nutt. Hairy Meadow Parsnip. Stem erect, branching above, pubescent at the nodes, $2-7 \mathrm{ft}$. high ; leaves petioled, 1-2-ternate, slightly pubescent ; leaflets mostly thin, ovate, toothed, incised or lobed toward the apex, entire toward the base; umbels long-peduncled, few-rayed; fruit oblong, lateral and central ribs strongly winged. May_June. Along streams.

\section{ERYNGIUM.}

Annual, biennial or perennial herbs ; stems erect or creeping; leaves simple, mostly linear and spiny-toothed; flowers white or blue, in dense, bracted heads or spikes, flowers bracteolate; calyx teeth rigid, persistent; petals erect, pointed; styles slender; fruit turbinate, scaly or granular, ribs obsolete, oil tubes usually 5 , minute.

E. aquaticum L. Button Snakeroot. Perennial; stem erect, branched above, striate, glaucous, 2-3 ft. high; leaves linear, often $2 \mathrm{ft}$. or more in length, rigid, glaucous, parallel-veined, fringed with white bristles; bracts shorter than the heads, entire, bracteoles similar but smaller; flowers white; fruit scaly. May-July. On damp soil. 


\section{SANICULA.}

Perennial or biennial herbs; stems erect, glabrous; leaves long-petioled, palmately divided; umbels compound, few-rayed, involucre leaf-like, umbellets few-flowered, involucels small; flowers yellow or purple; fruit flattened laterally, carpels not ribbed but armed with hooked bristles.

S. Marilandica L. Black Snakeroot. Perennial; stem stout, nearly simple, $2-3 \mathrm{ft}$. high; leaves palmately $5-7$-parted, the divisions obovate or oblanceolate, toothed; lower leaves long-petioled, the upper sessile; umbels of 2-4 long rays, leaves of the involucre 3parted; umbellets with numerous staminate flowers, pistillate flowers few; petals greenish-white; styles elongated and conspicuous, recurved; fruit ovoid, with $\check{5}$ large oil tubes. May-June. In dry woods.

\section{CORNACEA. DOGWOOD FAMILY.}

Trees or shrubs; leaves simple, alternate, opposite or verticillate, usually entire, exstipulate; flowers perfect, polygamous or diœcious, cymose or capitate; calyx tube coherent with the ovary, 4-5-toothed or truncate; petals $4-5$ or wanting; stamens 4-10, inserted with the petals in the disk at the top of the ovary; ovary 1-2-celled, style long or short; fruit a berry-like, 1-2-celled, 1-2-seeded drupe.

\section{CORNUS.}

Shrubs or small trees; leaves usually opposite or verticillate ; flowers perfect, in cymes or heads, the heads subtended by a large involucre; calyx tube minutely 4 -toothed; petals 4 ; stamens 4 ; stigma capitate or truncate; fruit a 2-celled, 2 -seeded drupe.

1. C. Florida L. Flowering Dogwood. Small trees; bark rough, black; leares opposite, petioled, ovate to ovate-lanceolate, entire, green and shining above, paler and often pubescent beneath; flowers small, greenish, in heads which are subtended by 4 large, white or pink, obcordate bracts, thickened and greenish at the sinus; fruit ovoid, bright red. April-May. In rich woods. 
2. C. Amonum Mill. Kinnikinnik. A shrub, 6-10 ft. high; twigs purple, pubescent when young; leaves opposite, petioled, ovate or oblong, acuminate, smooth above, silky-pubescent below; flowers white, in rather close cymes; drupe blue, stone somewhat oblique. May-June. In low woods.

3. C. Asperifolia Michx. Rough-Leaved Dogwood. A shrub 8-12 ft. high; twigs slender, reddish-brown, often warty, densely pubescent when young; leaves opposite, short-petioled, lance-ovate or oblong, acute or acuminate, rough-pubescent above, woolfy pubescent below; cymes flat, spreading, the peduncle and branches roughpubescent; flowers white; drupe white or pale blue, stone depressedglobose. May-June. In dry woods.

4. C. Alternifolia L. Alternate-leaved Dogwood. A shrub or small tree; twigs greenish, striped; leaves alternate, often clustered at the ends of the twigs, long-petioled, oval, acute at the apex and often at the base, minutely toothed, pale and pubescent beneath; cymes loose and open; flowers white; drupe deep blue, seeds globose. May-June. Banks of streams.

\section{NYSSA.}

Trees or shrubs; leaves alternate, petioled, entire or fewtoothed; flowers polygamous or diœecious, the staminate in many-flowered heads or cymes, the pistillate in small clusters or solitary; calyx tube 5-toothed or truncate; petals minute or wanting; stamens 5-10; ovary 1-celled, 1-ovuled, style long and recurved; fruit a 1 -seeded drupe.

1. N. sylvatica Marsh. Black Gum. A tree with widely spreading branches and dark, rough bark, wood light-colored, very tough, base of trunk often enlarged; leaves often clustered at the ends of the twigs, oval or obovate, acuminate or obtuse at the apex, entire, smooth and shining above, pubescent beneath, becoming bright red in autumn ; staminate flowers in capitate clusters ; pistillate $3-10$ in a long-peduncled cluster; drupe ovoid, dark blue or nearly black, $\frac{1}{2}$ in. long, stone slightly ridged. April-May. In rich, wet soil.

2. N. aquatica L. Tupelo. A large tree, similar to the preceding; leaves long-petioled, oval or ovate, acute at each end, entire or coarsely toothed, the lower sometimes cordate, smooth above, tomentose beneath, 4-8 in. long; staminate flowers in capitate clusters; pistillate flowers on long peduncles, solitary; drupe ovoid, dark blue, stone sharply ridged. April. In swamps. 


\section{CLETHRACER. WHITE-ALDER FAMILY.}

Trees or shrubs; leaves alternate, petioled, serrate, deciduous, exstipulate, pubescence stellate; flowers in solitary or clustered terminal racemes, small, white; calyx 5-parted, persistent; petals 5 , slightly united below, deciduous; stamens 10 , anthers sagittate; ovary free, style slender, 3-cleft, stamens and style exserted; fruit a globose, dehiscent capsule, 3-celled, 3-valved, many-seeded.

\section{CLETHRA.}

Characters of the family.

C. Alnifolia L. White Alder. Shrubs, $3-8$ ft. high; twigs and branches tomentose; leaves short-petioled, obovate, acute at the apex, cuneate at the base, serrate, smooth on both sides; racemes simple or panicled, flowers on short pedicels subtended by short, deciduous bracts; flowers $\frac{1}{3}$ in. wide, very fragrant; filaments smooth; style hairy, longer than the stamens; capsule about the length of the calyx. June-July. In damp woods, usually on sandy soil.

\section{MONOTROPACEÆ. INDIAN PIPE FAMILY.}

Low herbs ; saprophytic on decaying roots or vegetable matter; stems fleshy, leafless, but with numerous leaf-like bracts ; flowers solitary or clustered, perfect, regular; sepals 2-6, erect, slightly united at the base; petals $2-6$, distinct or united; both calyx and corolla deciduous; stamens $6-12$, hypogynous, distinct or united; ovary free, style long or short, stigma capitate, or peltate and rayed ; fruit a 1-6-celled, many-seeded capsule, seeds minute, reticulated.

\section{MONOTROPA.}

Stems fleshy, single or clustered, simple; bracts numerous ; flowers solitary, nodding, the capsule becoming erect in fruit; sepals $2-4$, deciduous; petals $5-6$, somewhat persistent; sta- 
mens 10-12, anthers peltate ; ovary 5 -celled, style short, stigma peltate; capsule 5-celled, 5 -valved.

M. uniflora L. Indian Pipe. Stem smooth, succulent, 4-6 in. high ; bracts ovate or lanceolate ; flower tubular, $\frac{3}{4}-1$ in. long, inodorous; stamens a little shorter than the petals; capsule angled, $\frac{1}{2}-\frac{3}{4}$ in. long; whole plant waxy white, turning black in drying. JuneAugust. In moist, shady woods.

\section{HYPOPITYS.}

Low, saprophytic herbs; stems erect, simple, pubescent above; bracts numerous; flowers in a one-sided, terminal raceme; terminal flowers usually with 5 petals and 10 stamens; the others with 4 petals and 8 stamens; sepals as many as the petals; petals saccate at the base; ovary free, style longer than the stamens, stigma ciliate; capsule 3-5-celled, many seeded.

H. Hypopitys (L.) Small. Pine-sap. Stems single or clustered, white or reddish, t-8 in. high; bracts ovate-lanceolate; flowers succulent, fragrant, $\frac{1}{2}-\frac{3}{4} \mathrm{in}$. long; capsule oval, $\frac{1}{4}$ in. long. June-August. In dry, shady woods.

\section{ERICACE ÆE. HEATH FAMILY.}

Trees, shrubs or perennial herbs; leaves alternate or opposite, simple, exstipulate, often evergreen; flowers axillary or terminal, solitary or variously clustered, perfect; calyx 4-5-parted or cleft, usually persistent ; corolla 4-5-lobed or parted; stamens 5-10, hypogynous, distinct, anthers 2celled, often awned; ovary free, 2-5-celled, style long or short, stigma entire or 3-lobed; fruit a 2-5-celled capsule or berry, seeds few or numerous. [Plants of this family are rarely found on lime soils.]

\section{AZALEA.}

Shrubs, often much branched; leaves alternate, thin, deciduous; flowers very showy in terminal umbels from scaly 
buds which become well developed the previous season; calyx very small, 5-parted; corolla bell-shaped, the tube long and slender, the limb spreading and somewhat one-sided; stamens usually 5, sometimes 10, declined, anthers awnless; style long and slender, declined, stigma capitate; capsule oblong or linear, 5-celled, many-seeded, seeds very small, scale-like.

1. A. nudiflora L. Wild Honeysuckle. A branching shrub, 4-6 ft. high; twigs smooth or with a few coarse hairs; leaves obovate or oblong, ciliate-serrate, pubescent, becoming smooth above ; petioles short; flowers appearing with or before the leaves, pink or white, sometimes yellowish, fragrant, 1-2 in. wide, tube pubescent but not glandular; capsule erect, linear-oblong, $\frac{2}{3}-\frac{3}{4}$ in. long. April-May. Swamps and banks of streams; flowers extremely variable in size and color.

2. A. viscosa L. Swamp Honeysuckle. A shrub, 4-6 ft. high ; branches hairy; leaves obovate, coriaceous, mucronate at the apex, mostly smooth above, pubescent on the veins beneath; petioles very short; flowers appearing later than the leaves, white, fragrant, $1 \frac{1}{2}-2$ in. long, tube long, glandular-viscid; capsule erect, $\frac{1}{2}-\frac{2}{3}$ in. long, bristly. June-July. In swamps.

\section{KALMIA.}

Erect and branching shrubs; leaves alternate, opposite or in 3's, entire, coriaceous, evergreen ; flowers showy, in corymbs or 1-3 in the axils; calyx 5-parted; corolla flat-campanulate or rotate, 5 -lobed; stamens 10 , the anthers placed in pouches in the corolla, filaments straightening elastically at maturity and so bringing the anthers in contact with the capitate stigma; style long and slender; capsule globose, 5-celled, many-seeded.

1. K. angustifolia L. Sheep Laurfi. A shrub 1-3 ft. high, with smooth, nearly erect branches; leaves petioled, opposite or in 3's, oblong, obtuse at both ends, dark green above, paler beneath; corymbs lateral, glandular; flowers purple or erimson, $\frac{1}{3}-\frac{1}{2}$ in. broad; pedicels slender, recurved in fruit; calyx pubescent, persistent; style persistent; capsule depressed-globose. April-June. On hillsides; more abundant northward.

2. K. latifolia L. Calico Bush. A shrub 4-10 ft. high; branches stout, smooth; leaves mostly alternate, petioled, elliptical or oval, acute at each end, smooth and green on both sides; corymbs terminal, compound; flowers white to rose color, showy, 1 in. broad; 
calyx and corolla glandular; pedicels long, slender, viscid-glandular, erect in fruit; calyx and style persistent. May-June. Shady banks on rocky or sandy soil.

\section{LEUCOTHÖ̈.}

Shrubs; leaves alternate, entire or serrate, deciduous or persistent; flowers white or pink, in terminal or axillary racemes ; pedicels jointed ; calyx deeply 5-parted, persistent; corolla cylindrical or urn-shaped, 5-toothed; stamens 10, included, anthers curved or mucronate; disk 10-lobed; ovary 5-celled, style slender, stigma capitate; fruit a 5-celled, 5-valved, many-seeded capsule.

1. L. axillaris (Lam.) Don. Downy Leucothö̈. A shrub 2-4 ft. high ; branches curved, puberulent when young; leaves oval to elliptical, spinose-serrate, at least near the apex, coriaceous, evergreen, short-petioled, dark green and shining above, paler and slightly pubescent beneath; racemes axillary, sessile, about half the length of the leaves, densely many-flowered; corolla cylindrical ; anthers horned at the summit; stigma 5-parted. February-March. Banks of streams.

2. L. racemosa (L.) Gray. Swamp Leucothö̈. A shrub 4-10 ft. high; branches straight, smooth or puberulent; leaves ovate or oblong, short-petioled, thin, deciduous, nearly or quite smooth above, pubescent beneath; racemes mostly terminal, longer than the leaves, and appearing with or before them; pedicels jointed; calyx with 2 persistent bracts at the base ; anthers 2 -awned; style slender, stigma capitate; capsule subglobose. April-June. Margins of swamps and streams.

\section{PIERIS.}

Shrubs or small trees; leaves alteruate, often persistent and green through the winter; flowers in terminal or axillary racemes or clusters, nodding on bracted pedicels; calyx deeply 5-parted; corolla ovoid, urn-shaped or bell-shaped, 5-lobed with recurved teeth; stamens 10, included, anthers awned or awnless; disk 10-lobed; ovary 5-celled, style thick, stigma truncate; fruit a 5-celled, 5-angled, globose, manyseeded capsule.

P. Nitida (Bartr.) B. \& H. Fetter-bush. A shrub 2-6 ft. high ; branches 3-angled, smooth, yellowish-green ; leaves evergreen, oval or oblong, very thick and coriaceous, entire, the margins bor- 
dered by a prominent nerve and revolute, short-petioled; flowers in numerous axillary, umbel-like clusters, fragrant; calyx lobe spreading, purple; corolla ovoid with a narrow throat, white or bright pink, $\frac{1}{3}$ in. long; anthers awned; capsule ribbed at the sutures. March-May. Common in low, pine barrens.

\section{OXYDENDRUM.}

A small tree; leaves alternate, petioled, deciduous; flowers white, in long and slender, one-sided, panicled racemes; pedicels 2-bracted; calyx 5-parted, persistent; corolla ovoid, 5 -toothed; stamens 10, about equaling the corolla; ovary 5-celled, style thick ; fruit a conical, 5-celled, 5-angled, manyseeded capsule.

O. ARboreum (L.) DC. Sour-Wood. A small tree with smooth, dark-colored bark; leaves oval to oblong, acuminate, serrulate, smooth on both sides, prominently reticulate-veined, sour to the taste; petioles slender; panicles terminal, pubescent; flowers white, $\frac{1}{4}$ in. long, pedicels curved in fruit; style persistent. April-June. In rich, moist woods.

\section{EPIGÆA.}

Prostrate or trailing shrubs; stems rusty-pubescent, 6-12 in. long; leaves alternate, coriaceous, evergreen; flowers in dense, bracted, terminal racemes or clusters; calyx 5-parted, persistent; corolla salver-shaped, 5-lobed; stamens 10, about the length of the corolla tube; ovary 5-lobed, style columnar, stigma 5-lobed; fruit a globose, hairy, 5-celled, many-seeded capsule.

E. repens L. Ground Laurel. Stems creeping, the young twigs ascending; leaves oval or somewhat cordate, entire, reticulateveined, smooth above, hirsute beneath; petioles short, hirsute; racemes shorter than the leaves; flowers bright pink, $\frac{1}{2}$ in. broad, very fragrant. February-March. In dry woods, often covering considerable areas.

\section{VACCINIACEÆ. HUCKLEBERRY FAMILY.}

Shrubs or small trees; leaves alternate, simple, exstipulate; flowers clustered or solitary, perfect; pedicels bracted; 
calyx tube adherent to the ovary, 4-5-lobed; corolla globose, tubular or campanulate, 4-5-lobed; stamens twice as many as the lobes of the corolla, filaments usually short, flattened; ovary 2-10-celled, style slender, stigma simple or minutely lobed; fruit a globose berry, 2-10-celled, cells 1-severalseeded. [Rare on lime soils.]

\section{GAYLUSSACIA.}

Low branching shrubs, mostly resinous-dotted; leaves serrate or entire; flowers small, white or pink, in lateral, bracted racemes, nodding; pedicels usually 2 -bracteolate; calyx tube short, obconic, the lobes persistent; corolla ovoid to bellshaped, 5-lobed, the lobes erect or recurved; stamens equal, usually included, anthers awnless ; fruit a 10-seeded berry.

1. G. Frondosa (L.) T. \& G. TAngleberry. An erect shrub 1-3 ft. high; branches spreading, slender, gray, slightly pubescent; leaves entire, oblong or obovate, obtuse, thin, smooth and green above, paler, pubescent, and with resinous dots beneath; petioles short; racemes few-flowered; corolla small, greenish-pink, short-bell-shaped; bracts small, oblong, shorter than the pedicels; berry depressedglobose, dark blue, glancous, sweet, about $\frac{1}{3} \mathrm{in}$. in diameter. AprilMay. On low ground.

2. G. dumosa (Andr.) T. \& G. Dwarf Huckleberry. A branching shrub, 1-2 ft. high; branches pubescent above, usually leafless below; leaves thick and firm, oblong-obovate, obtuse, sessile or nearly so, serrulate, soon smooth and shining above, pubescent or hirsute below; racemes short, few-flowered; bracts ovate, leaf-like, usually longer than the hirsute pedicels ; corolla white, bell-shaped, angled; berry black, $\frac{1}{3}-\frac{1}{2}$ in. in diameter, insipid. April-May. Low, sandy pine barrens and swamps.

\section{VACCINIUM.}

Shrubs or small trees; leaves entire or serrulate, often coriaceous and evergreen; flowers terminal or lateral, clustered or solitary, nodding; pedicels 2-bracteolate; calyx tube globose or hemispherical, 4-5-lobed, persistent; corolla urnshaped, cylindrical or campanulate, 4-5-lobed; stamens twice as many as the lobes of the corolla, anthers awned or awn- 
less; ovary 4-5-celled, each cell partially divided by a partition which makes the ovary appear 8-10-celled, style slender, stigma simple; fruit a many-seeded berry.

1. V. corymbosum L. High-bush Blueberry. An erect shrub, 6-12 ft. high; branches rigid, young twigs minutely warty; leaves deciduous, oval to ovate-lanceolate, acute, margins bristly, serrulate, smooth or pubescent, short-petioled; racemes numerous, appearing with or before the leaves; bracts oval or oblong, deciduous; flowers white or pink; corolla almost as long as the pedicel, cylindrical ; berry globose, blue or black, flavor slightly acid, pleasant. February-April. Common in woods and thickets, whole plant extremely variable.

2. V. stamineum L. Deerberry. An erect shrub, 3-10 ft. high; branches widely spreading, twigs smooth or puberulent; leaves deciduous, oval or oblong, acute or acuminate at the apex, obtuse or slightly cordate at the base, firm, smooth, and green above, pale and slightly pubescent beneath, petioled; racemes with leaf-like bracts; flowers numerous, drooping, on jointed, slender pedicels; corolla bell-shaped, purplish-green; 2-awned anthers and style exserted; berry globose or pear-shaped, inedible. April-June. Dry woods.

3. V. ARboreym Marsh. Farkleberry. Tree-like, sometimes $30 \mathrm{ft}$. high ; bark gray; twigs slender, smooth or pubescent; leaves deciduous, ovate or oval, mucronate, entire or glandular-dentate, coriaceous, green above, often slightly pubescent beneath; racemes with leaf-like bracts ; pedicels slender, drooping; corolla campanulate, white; anthers included; style exserted ; berry globose, black, mealy, ripening in winter. May-June. Common in dry, open woods.

\section{PRIMULACE E. PRIMROSE FAMILY.}

Annual or perennial herbs; leaves scattered, or clustered and radical; inflorescence various, flowers regular, perfect; calyx free or adherent to the base of the ovary, usually 4-5lobed and persistent; corolla 4-5-lobed; stamens as many as the lobes of the corolla and opposite them, inserted on its tube or hypogynous, filaments distinct or slightly united at the base; ovary 1-celled, with a free central placenta, style single, stigma entire, capitate; fruit a 1-celled, many-seeded capsule. 


\section{STEIRONEMA.}

Perennial herbs ; leaves opposite or whorled, simple, entire; flowers yellow, axillary or racemose, on slender peduncles; calyx tube 5-parted, persistent; corolla 5-parted, rotate, tube very short or none, the lobes denticulate at the apex, and in the bud each one enclosing a stamen; stamens 5, distinct or slightly united at the base, sterile rudiments often alternating with them; ovary globose, style slender; fruit a globose, 5 -valved, few or many-seeded capsule.

1. S. ciliatum (L.) Raf. Fringed Loosestrife. Stems erect, slender, simple or branched, 1-3 ft. high; leaves opposite, ovate to ovate-lanceolate, acute at the apex, rounded at the base, margins and petioles hairy-fringed; flowers solitary on axillary peduncles, $\frac{3}{4}-1$ in. broad; petals broadly ovate or roundish, denticulate; calyx shorter than the capsule. June-August. Woods and thickets.

2. S. Lanceolatum (Walt.) Gr. Lance-Leaved Loosestrife. Stem erect, slender, smooth, simple or branched, 1-3 ft. high ; leaves opposite or the upper ones whorled, the lower leaves petioled, broadly ovate or orbicular, the upper linear-lanceolate or linear, sessile, margins smooth or ciliate; flowers on slender axillary branches, $\frac{1}{2}-\frac{3}{4} \mathrm{in}$. broad; petals cuspidate; capsule nearly as long as the calyx lobes. June-August. On damp soil.

\section{ANAGALLIS.}

Annual or perennial herbs; stems erect or diffuse; leaves opposite or whorled; flowers axillary, peduncled; calyx tube 5-parted, persistent; corolla rotate, 5-parted, longer than the calyx; stamens 5 , inserted on the base of the corolla, filaments bearded; ovary globose, style slender, stigma capitate; fruit a many-seeded capsule with circumscissile dehiscence.

A. arvensis L. Poor Man's Weather-glass. Annual; stem spreading, widely branched, 4-angled, smooth, 4-12 in. long; leaves opposite, sessile, ovate, black-dotted beneath ; flowers on peduncles longer than the leaves, nodding in fruit; corolla glandular-ciliate, longer than the acute calyx lobes, bright red, opening in sunshine; capsule globose, tipped by the persistent style. May-July. Introduced, and common in fields and gardens. 


\section{DODECATHEON.}

Perennial, acaulescent herbs; leaves all radical, in a rosulate tuft; flowers in an involucrate umbel at the summit of a naked scape; calyx 5-cleft, the lobes reflexed; corolla 5cleft, tube very short, lobes reflexed; stamens 5, filaments short and united at the base, anthers long and erect; ovary free from the calyx, style long and slender, exserted, stigma capitate; fruit an oblong, many-seeded capsule.

D. Meadia L. Shooting Star. Rootstock stout; leaves spatulate or oblong, tapering into a petiole, smooth, entire or crenate; scape smooth, 10-20 in. high; umbel many-flowered, flowers showy, nodding on long and slender pedicels which become erect in fruit; corolla purple or white ; involucral bracts lanceolate or linear; capsule ovoid, $\frac{1}{2}-\frac{3}{4}$ in. long, seeds small, punctate. April-June. In dry woods; one of the most beautiful wild flowers.

\section{EBENACEA. EBONY FAMILY.}

Trees or shrubs; leaves simple, alternate, entire, exstipulate, petioled; flowers polygamous, diœcious or rarely perfect, the staminate cymose, the pistillate axillary and solitary ; calyx free from the ovary, 3-7-lobed, persistent; corolla 3-7lobed, deciduous; stamens $15-20$ in the staminate flowers, inserted on the base of the corolla, often in pairs; usually a few abortive stamens in the pistillate flowers; ovary superior, several-celled; 1-3 ovules in each cell, styles 2-8, distinct or united below ; fruit fleshy, several-seeded.

\section{DIOSPYROS.}

Trees or shrubs; leaves broad; flowers lateral; calyx 4-6lobed, persistent, becoming enlarged and thickened in fruit; corolla bell-shaped, 4-6-cleft; stamens usually 16 in the staminate flowers; styles in the pistillate flowers $2-4$, united below, cells of the ovary double the number of the styles; fruit pulpy, with several large, flat seeds.

D. Virginiana L. Persmion. Trees, with rough, black bark and very hard wood; leaves oval or ovate-oblong, acute or 
acuminate at the apex, rounded or slightly cordate at the base, entire, smooth and dark green above, pale and often pubescent beneath, short-petioled, deciduous ; flowers yellowish-white, the parts mostly in 4's ; fruit globose, edible when ripe, very astringent when green; seeds large, compressed, often wanting. May-June. Fruit ripening late in the fall; very common.

\section{SYMPLOCACEÆ. SWEET-LEAF FAMILY.}

Trees or shrubs; leaves simple, alternate, petioled, exstipulate; flowers in sessile axillary clusters ; calyx tube partially adherent to the ovary, 5-lobed; corolla 5-lobed; stamens very numerous, usually somewhat united in clusters, filaments filiform; ovary 2-5-celled, ovules 2 in each cell, style slender, stigma entire or 3-5-lobed; fruit a small drupe or berry, 1-5-seeded.

\section{SYMPLOCOS.}

Characters of the family.

S. tinctoria (L.) L'Her. Sweet Leaf. A shrub or small tree; leaves alternate, coriaceous, oval or oblong, acute at each end, crenate-dentate, pubescent when young, becoming smooth above, somewhat evergreen, sweet to the taste; petioles short, pubescent; flower clusters sessile, scaly-bracted; flowers light yellow; calyx smooth, top-shaped; stamens in 5 sets ; stigma entire; fruit becoming nearly dry, 1-seeded. March-April. Banks of streams and low woods.

\section{STYRACACEÆ. STORAX FAMILY.}

Trees or shrubs; leaves simple, alternate, exstipulate; flowers regular, perfect, clustered or solitary; calyx more or less adherent to the ovary, 4-8-toothed or truncate; corolla hypogynous or inserted on the calyx, 4-8-lobed or sometimes polypetalous; stamens inserted on the base of the corolla, twice as many as its lobes or more numerous, distinct, monadelphous or polydelphous; ovary 2-5-celled, style slender, stigma simple or lobed; fruit berry-like or dry, 1-5-celled, one seed in each cell. 


\section{MOHRODENDRON.}

Trees or shrubs; pubescence stellate; leaves ample, dentate, petioled; flowers in short lateral racemes or clusters, white, bell-shaped, drooping on slender pedicels, appearing with or before the leaves; calyx obconic, obscurely 4 -toothed, adnate to the ovary, teeth persistent; corolla 4-lobed or 4-petalous; stamens 8-16, filaments flat, distinct or united below; the short style persistent, ovary 2-4-celled, ovules 4 in each cell ; fruit dry, prominently 2-4-winged, 1-3-seeded.

1. M. dipterum (Ell.) Britt. Two-winged Silver-bell. A small tree; leaves oval, serrate, pubescent, 4-6 in. long; racemes 2-4-flowered; flowers white, 1 in. wide, on long and slender pedicels; petals 4, nearly or quite distinct; stamens 8 , distinct, anthers spreading; ovary 3-celled; fruit compressed, 2 -winged, 1 in. long. March-April. In rich woods.

2. M. Carolinianum (L.) Britt. Four-winged Silver-bell. Small trees; leaves oval to ovate-oblong, finely serrate, pubescent when young, becoming smooth when old, 2-4 in. long; flowers 2-4 in a cluster, pedicels long and slender; corolla 4-lobed; stamens mostly 12, united below the middle, anthers erect; ovary 4-celled; fruit $1-1 \frac{1}{2}$ in. long, exceeding the pedicel, prominently 4 -winged. March-April. River banks.

\section{STYRAX.}

Shrubs; pubescence downy or scurfy-stellate; leaves alternate, entire or toothed, deciduous; flowers white, in leafy racemes; calyx tube 5-toothed, slightly coherent with the base of the ovary; corolla 5-parted, the lobes spreading or reflexed; stamens 10, inserted on the base of the corolla, distinct, or monadelphous below; ovary 3-celled, style filiform, stigma 3-lobed; fruit a globose, 3-valved, 1-seeded capsule.

1. S. Americana Lam. Smooth Storax. A shrub 4-8 ft. high; leaves ovate to obovate, usually acute at both ends, entire or few-toothed, thin, smooth when old, often scurfy below when young; flowers solitary or in 4-6-flowered, scurfy racemes, pedicels slender; calyx teeth short, subulate; pedicels and calyx glandulardotted; fruit globose, puberulent, $\frac{1}{4}$ in. in diameter. March-May. Banks of streams. 
2. S. Pulverulenta Michx. Downy Storax. A shrub 4-6 ft. high; leaves elliptical to obovate, acute at each end, entire or slightly toothed, the lower surface as well as the twigs, pedicels and calyx densely scurfy or stellate-pubescent; racemes short, terminal or axillary, pedicels short; flowers fragrant; calyx teeth subulate; fruit globose, puberulent. March-April. Pine-barren swamps.

3. S. Grandiflora Ait. Large-Leaved Storax. A shrub 4-10 ft. high; leaves large, 3-6 in. long, obovate or oval, acute at each end, entire or coarsely toothed, smooth above, white-tomentose below; petioles short; racemes many-flowered, flowers longer than the pedicels ; calyx furrowed, teeth triangular, acute; fruit obovoid, puberulent. March-May. In rich woods.

\section{OLEACEA. OLIVE FAMILY.}

Trees or shrubs; leaves opposite, simple or compound, exstipulate, deciduous or evergreen; flowers in terminal or axillary clusters, perfect, polygamous or diœcious; calyx small, 4-parted, free from the ovary, or none ; corolla 4-lobed, or 4-petalous, or wanting; stamens 2-4, distinct; ovary 2-celled, 2 ovules in each cell, style usually short or none; fruit a 1-2-seeded capsule, samara, drupe or berry.

\section{FRAXINUS.}

Trees; leaves petioled, compound, odd-pinnate, deciduous; flowers in racemes or fascicles from buds of the previous season, polygamous or diøecious; calyx minutely 4-toothed, or wanting; corolla usually wanting; stamens $2-4$, hypogynous, anthers longer than the filaments; stigma 2-cleft; fruit a 1-2-seeded samara winged at the apex.

1. F. Americana L. White Ash. A large tree; bark rough, gray, wood hard, strong, elastic ; twigs and petioles glabrous ; leaflets usually 7 , ovate to ovate-lanceolate, acuminate at the apex, rounded or obtuse at the base, entire or slightly serrate, smooth above, often pubescent beneath, short-stalked ; flowers mostly diøecious ; calyx of the pistillate flowers persistent; samara $1 \frac{1}{2}-2$ in. long, winged only at the apex, wing spatulate or oblanceolate. April-May. In rich woods and swamps.

2. F. Pennsylvanica Marsh. Red Ash. A small tree; bark rough, dark gray; twigs and petioles densely velvety-pubescent; 
leaflets 5-9, oblong-ovate to ovate-lanceolate, acuminate at the apex, narrowed into a short stalk at the base, finely serrate, smooth above, velvety-pubescent beneath ; calyx of the pistillate flowers persistent; samara $1 \frac{1}{2}-2$ in. long, the wing somewhat decurrent along the sides, oblanceolate or spatulate, often notched. March-April. Swamps and moist soil.

3. F. Caroliniana Mill. Water Ash. A small tree; wood soft, light and weak; twigs smooth or pubescent; leaflets $5-7$, ovate or elliptical, acute at the apex, acute or obtuse at the base, entire or slightly serrate, smooth or slightly pubescent, stalked; flowers diøcious; calyx persistent; samara often 3 -angled or 3-winged, wings decurrent nearly to the base, oblong or oval, pinnately veined. March-April. In swamps and wet soil.

\section{CHIONANTHUS.}

Shrubs or small trees; leaves simple, opposite, entire, petioled, deciduous; flowers in panicles borne on wood of the previous season; calyx small, 4-cleft, persistent; corolla wheel-shaped, 4-parted, the lobes long and linear; stamens $2-4$, included, inserted on the base of the corolla; style short, stigma 2-lobed; fruit a 1-seeded drupe.

C. Virginica L. Fringe-tree. A small tree, with smooth, light gray bark and spreading branches; leaves oval to oblong, acute or obtuse at each end, smooth or slightly pubescent; panicles large and loose, leafy-bracted, appearing with the leaves; flowers on slender, drooping pedicels; petals 1 in. or more in. length; drupe ovoid, purple, $\frac{1}{2}-\frac{2}{3}$ in. long. April-May. Along streams, usually on light soil.

\section{LIGUSTRUM.}

Shrubs; leaves simple, opposite, entire, deciduous or sometimes persistent; flowers in terminal panicles or thyrses, white, small; calyx minutely 4-toothed or truncate; corolla funnel-form, 4-lobed; stamens 2 , short, inserted in the tube of the corolla; ovary free, 2-celled, 2 ovules in each cell, style short; fruit a 1-4-seeded, globose berry.

L. vulgare L. Privet. A branching shrub 4-10 ft. high; branches long and slender; leaves somewhat coriaceous, lanceolate to obovate, short-petioled, tardily deciduous ; panicles dense, minutely pubescent; flowers fragrant, $\frac{1}{4}$ in. wide; stamens included; berries black. April-June. Introduced from Europe and used largely for hedges. 


\section{OLEA.}

Trees or shrubs; leaves evergreen, opposite, simple, coriaceous; flowers in axillary racemes or panicles, fragrant; calyx 4-toothed, persistent; corolla short-salver-form, 4-lobed; stamens 2, exserted; stigma globose or 2-lobed; fruit a 1-2seeded drupe.

1. O. Americana L. American Olive. A small tree; bark smooth, light gray; leaves thick, elliptical to obovate, petioled, entire, smooth and shining; racemes axillary, shorter than the leaves; flowers polygamous or diœcious, bracted; drupe ovoid, dark purple, bitter and astringent. March-April. Along streams and margins of swamps; more abundant near the coast.

2. O. Fragrans Thunb. Sweet Olive. A small tree; leaves thick, lanceolate-oblong, petioled, serrate, smooth and shining; flowers in axillary corymbs, white or pink, very fragrant; drupe globose, black. March-May. Introduced from China and widely cultivated.

\section{LOGANIACEA. LOGANIA FAMILY.}

Herbs, shrubs or twining vines; leaves simple, opposite, connate, or the bases connected by a stipular line; flowers perfect, regular, in spikes or cymes, or axillary and solitary ; calyx tube free from the ovary, 4-5-lobed; corolla tubular to campanulate; stamens as many as the lobes of the corolla and inserted in the tube; ovary mostly 2-celled, style single, stigma 2-5-cleft; fruit a 2-valved, few- or many-seeded capsule.

\section{GELSEMIUM.}

Twining woody vines; leaves evergreen, opposite, bases connected by a stipular line; flowers in bracted axillary or terminal cymes; pedicels scaly-bracted; calyx 5-parted, persistent; corolla funnel-form, 5-lobed, the lobes rounded; stamens 5, inserted near the base of the corolla tube, anthers oblong-sagittate; ovary 2-celled, style 1, deeply 4-parted; fruit an oblong, compressed, 2-celled capsule, seeds several, flattened and winged. 
G. sempervirens (L.) Ait. Yellow Jessamine. Stem smooth, twining high; young branches purple; leaves lanceolate to ovate, acuminate at the apex, acute to slightly cordate at the base, entire, coriaceous; flowers $1 \frac{1}{2} \mathrm{in}$. long, bright yellow, fragrant, of two forms, in one of which the anthers are exserted and the style included, while in the other the anthers are included and style long; pedicels short; capsule flattened contrary to the partition, seeds oval, winged at the apex. March-April. Woods and river banks.

\section{SPIGELIA.}

Herbs ; leaves opposite, entire; flowers in one-sided, scorpioid spikes, or rarely solitary; calyx 5-parted, its lobes slender, persistent; corolla tubular-funnel form, 5-lobed, the tube many-nerved; stamens 5, inserted in the tube of the corolla, anthers linear; style slender, jointed in the middle, bearded above, stigma capitate, ovary 2-celled, ovules many; fruit a capsule, few-seeded, seeds not winged.

S. Marilandica L. Pinkroot. Perennial; stem simple, erect, smooth, 4-angled, 1-2 ft. high ; leaves ovate to ovate-lanceolate, acute at the apex, rounded or sessile at the base, smooth above, pubescent on the veins beneath; spikes terminal, many-flowered, sometimes forking, bracted below the short pedicels ; corolla $1 \frac{1}{2}-2$ in. long, dark red outside, yellow within, lobes lanceolate, spreading; anthers and style exserted; capsule somewhat flattened, seeds flattened, orbicular. May-June. In rich woods.

\section{GENTIANACEAE. GENTIAN FAMILY.}

Herbs; mostly with a bitter juice; stem smooth; leaves simple, opposite or verticillate, exstipulate, entire; flowers perfect, regular, terminal or axillary, clustered or solitary; calyx 2-12-parted, persistent; corolla 4-12-lobed; stamens as many as the lobes of the corolla and inserted in its lobes or throat; ovary superior, 1- or partly 2-celled, ovules numerous, attached to parietal placentæ, style simple or none, stigma entire or 2-lobed; fruit a 1-celled, or imperfectly 2-4celled capsule dehiscent by 2 valves. 


\section{SABBATIA.}

Annual or biennial herbs; stems erect, glabrous, branching, often angled; leaves opposite or verticillate, sessile or rarely petioled; flowers terminal, white or red, solitary or cymose; calyx 4-12-parted, the tube usually very short, the lobes long and narrow; corolla wheel-shaped, deeply 4-12-parted; stamens 5-12 and inserted on the throat of the corolla, anthers slender, curved; ovary 1-celled, style with filiform lobes, twisted; capsule globose, 2 -valved, many-seeded, seeds reticulated.

1. S. macrophylla Hook. Large-Leaved Sabbatia. Biennial; stem erect, glaucous, rigid, hollow, corymbosely branched above, 2-3 ft. high ; leaves opposite, thick, ovate-lanceolate, acute at the apex, clasping at the base, strongly 3-5-nerved; flowers in large, flat-topped cymes, white, $\frac{1}{2}$ in. wide ; calyx 5 -parted, the lobes bristlelike, one-third the length of the lobes of the corolla. June-August. Low pine barrens, more common southward.

2. S. angularis (L.) Pursh. Bitterbloom. Annual; stem erect, square, wing-angled, smooth, widely branched, 1-2 ft. high; lower branches sometimes alternate, the others opposite; leaves numerous, ovate, acute, cordate-clasping at the base, 3-5-nerved, about as long as the joints; flowers in a panicled cyme, about $1 \mathrm{in}$. wide, rose color or purple; calyx lobes 5 , linear, about half the length of the obovate corolla lobes; style 2-cleft; capsule ovoid, about the length of the calyx lobes. July-August. On low rich soil.

3. S. stellaris Pursh. Marsh Pink. Stem obscurely 4-angled, widely branched, smooth, 1-2 ft. high ; branches all alternate ; leaves thick or somewhat fleshy, the lower spatulate, the upper lanceolateoblong or linear, sessile ; flowers on long peduncles, $1-1 \frac{1}{2}$ in. wide, pink to white, with a yellow eye; calyx lobes linear, shorter than the obovate divisions of the corolla; style deeply 2-cleft; capsule ovoid. June-September. In salt marshes.

4. S. campanulata (L.) Torr. Slender Marsh Pink. Stem obscurely 4-angled, slender; the branches alternate and diffuse ; leaves linear, the upper filiform, and the lower broader and obtuse, sessile, 1-1 $\frac{1}{2}$ in. long ; flowers on rather short peduncles, pink with a yellow eye, $1-1 \frac{1}{4}$ in. wide ; calyx lobes linear, as long as the oblong-obovate divisions of the corolla; style 2-cleft; capsule obovoid, about half the length of the calyx lobes. May-August. Low pine barrens and brackish marshes.

5. S. Gentianoides Ell. Pine-woods Pink. Stem erect, smooth, simple, or few-branched above, 9-15 in. high; leaves oblanceolate or 
oblong, narrowed at the base, the upper linear, sessile; flowers terminal, sometimes 2-3 together on short peduncles, 2-bracted; calyx lobes 7-12, narrowly lanceolate; corolla 7-12-parted, bright rose color, $1 \frac{1}{2}-2$ in. wide; anthers straight. June-August. Low pine barrens.

\section{GENTIANA.}

Annual or perennial herbs, mostly blooming after midsummer; leaves opposite or verticillate, sessile or shortpetioled; flowers showy, solitary or clustered, terminal or axillary; calyx tubular, 4-5-parted; corolla tubular, funnelform or salver-form, 4-5-lobed, often with plaited and toothed folds between the lobes; stamens $4-5$, alternate with the lobes of the corolla and inserted in the tube, distinct or united by the anthers, included; ovary 1-celled, styles short or none, stigmas 2 ; fruit a 1-celled, 2 -valved, many-seeded capsule.

1. G. Elliottir Chap. Elliott's Gentian. Perennial; stem erect, slender, somewhat rough-pubescent, 6-18 in. high; leaves ovate to narrowly lanceolate, acute at the apex, rounded and clasping at the base, rough-margined, 3-nerved; flowers in terminal and axillary clusters, about 2 in. long, sessile or nearly so, 2-bracted; calyx lobes oblong, twice as long as the tube; corolla funnel-form, bright blue without, deep blue and yellow within, the lobes short, ovate, obtuse, folds between the lobes 2-toothed and fimbriate; anthers cohering in a tube; seeds oblong, winged; plant quite variable. SeptemberOctober. In moist soil.

2. G. Porphyrio Gmel. Narrow-leaved Gentian. Perennial; stem erect, glabrous, simple or branched, 4-15 in. high; leaves opposite, linear and somewhat fleshy; flowers terminal, solitary; calyx lobes linear, erect, a little longer than the tube; corolla spreading, funnel-form, bright blue, $1 \frac{1}{2}-2$ in. long, the lobes ovate, acute, two or three times as long as the laciniate folds; anthers not united; seeds oblong, wingless. August-October. Moist pine barrens.

\section{FRASERA.}

Perennial or biennial herbs; stems mostly tall and glabrous; leaves opposite or verticillate, sessile; flowers in terminal, cymose panicles or thyrses; calyx 4-parted; corolla 4 -parted, the lobes spreading and bearing 1 or 2 fringed glands upon the upper face; stamens 4 , inserted in the tube of the corolla; ovary 1-celled, style usually short, persistent, 
stigmas entire or 2-lobed; fruit an ovoid, compressed, 2-valved, few-seeded capsule.

F. Carolinensis Walt. American Columbo. Perennial, root large, bitter; stem erect, stout, $4-8 \mathrm{ft}$. high; leaves in whorls of $4-6$, the lower spatulate or oblanceolate, the upper elliptical, becoming small and bract-like near the summit of the stem; flowering branches in whorls of 4, forming a large pyramidal panicle; pedicels slender; flowers about $1 \mathrm{in}$. wide; corolla rotate, yellowish-white with numerous brownish-purple spots, lobes oblong, with a large fringed gland near the middle; capsule ovoid, longer than the calyx; seeds flattened, winged. June-August. In rich and dry woods.

\section{APOCYNACE 2 . DOGBANE FAMILY.}

Perennial herbs or shrubs, with acrid milky juice; leaves simple, alternate, opposite or verticillate, exstipulate; flowers perfect, regular, solitary, cymose or paniculate; calyx 5-parted, persistent; corolla bell-shaped to salver-form, convolute in the bud; stamens 5 , inserted in the tube of the corolla and alternate with its lobes; ovary superior, usually of 2 distinct carpels united by the style, sometimes 2-celled or 1-celled with 2 parietal placentæ, style simple or 2-parted; fruit usually 2 follicles, many-seeded, seeds often with a coma.

\section{AMSONIA.}

Perennial herbs; stem erect, branched; leaves alternate; flowers in terminal panicles; calyx small, 5-parted; corolla small, pale blue, funnel- or salver-form, pubescent within; stamens inserted above the middle of the tube, included; ovary of 2 carpels, united at the top by the slender style, stigma globose, surrounded by a cup-shaped appendage ; fruit 2 slender, erect, many-seeded follicles, seeds not comose.

1. A. Amsonia (L.) Britt. Amsonia. Stem smooth and glabrous, branched above, 2-3 ft. high; leaves lanceolate, entire, acuminate at the apex, acute at the base, smooth above, glaucous or slightly pubescent beneath, short-petioled; flowers numerous, on bracted pedicels; corolla tube slender, smooth or sometimes pubescent above, 
the lobes narrow, as long as the tube; follicles slender, spreading, 4-6 in. long, seeds pubescent. April-June. Swamps and wet ground.

2. A. axgustifolia Michx. Narrow-leaved Amsonia. The whole plant villous when young, becoming smoother with age; stems finally much branched above, 2-3 ft. high; leaves crowded, linear or linear-lanceolate, fringed and revolute on the edges, almost sessile; corolla pale blue or white, funnel-form, smooth; follicles very slender, 2-5 in. long. April-May. On dry soil.

\section{VINCA.}

Erect or trailing herbs; juice only slightly milky; leaves opposite, entire, thick, smooth; flowers axillary; calyx tube short, obconic, lobes narrow, elongated; tube of the corolla with a callous ring at the throat, pubescent within, limb spreading, segments oblique; stamens 5, alternate with the lobes of the corolla, and inserted in the tube, included; disk of 2 glands alternate with the 2 carpels; style single, stigma enlarged; follicles erect or spreading, many-seeded, seeds not comose.

V. minor L. Periwinkle. Stem slender, trailing, often rooting at the nodes, 1-3 ft. long; leaves ovate, acute at the apex, shortpetioled, bright green; flowers axillary, solitary, 1 in. wide; calyx with linear lobes nearly as long as the inflated tube of the blue corolla; matured follicles slender, slightly divergent. January-June. Introduced from Europe and common in gardens.

\section{APOCYNUM.}

Perennial herbs; stems with very tough bark, branched above; leaves opposite, entire; flowers in terminal and axillary bracted cymes; calyx small, 5-parted, lobes acute; corolla bell-shaped, 5-lobed, with a small scale-like appendage at the base of each lobe; stamens 5 , distinct, inserted in the base of the corolla tube; ovaries 2, distinct, united by the styles, stigma obtuse, 2-lobed; follicles long, slender, many-seeded, seeds comose.

A. Cannabinum L. Indian Hemp. Stem erect, smooth, with numerous erect or ascending branches; leaves oval to oblong, mucronate at the apex, rounded at the base, pubescent beneath, short- 
petioled; cymes terminal, compact, shorter than the leaves; flowers on short, bracted pedicels, greenish-white, about $\frac{1}{4}$ in. broad; calyx lobes lanceolate, nearly as long as the tube of the corolla; corolla lobes erect; follicles very slender, tapering, 3-4 in. long. JuneAugust. Along fences and in thickets.

\section{NERIUM.}

Shrubs; leaves mostly verticillate in 3 's ; flowers in terminal cymes; calyx small, lobes acute; corolla salver-form, convolute, the throat of the tube crowned with cleft or fimbriate scales; stamens 5, short, included, anthers tipped with a hairy bristle; ovary of 2 carpels, style short; follicles erect, seeds comose.

N. Oleander L. Oleander. Stem erect, diffusely branched from below, 4-10 ft. high; leaves narrowly elliptical, acute at each end, thick and leathery, short-petioled; flowers showy, in large clusters, red or white, often double; scales of the crown 3-4-pointed unequal teeth; follicles fusiform, 3-4 in. long. April-November. Introduced from Palestine, common in cultivation and often spontaneous in the southern section.

\section{ASCLEPIADACE正. MILKIVEED FAMILY.}

Herbs, twining vines or sometimes shrubby plants, with milky juice ; leaves alternate, opposite or verticillate, exstipulate; flowers perfect, regular, in terminal and axillary cymes or umbels; calyx 5-parted, persistent, the tube short or none; corolla 5-parted, deciduous, rotate, campanulate or funnelform; stamens 5, inserted near the base of the corolla; filaments united into a tube (gymnostegium) enclosing the ovary, and bearing appendages which are often hood-like, and are termed the stamineal crown; anthers erect, 2-celled, the cells often with a thin membranous appendage at the apex or sometimes at the base; pollen masses waxy, usually 1 in each anther cell, attached in pairs and to the stigma by a connective stalk; ovary of 2 carpels, styles 2 , united into a single fleshy stigma; fruit a many-seeded follicle, seeds usually 
comose. Most species bloom late in the season. [The pollen masses are easily withdrawn from the anther-sacks, and are often found attached to the legs of insects which visit the flowers for nectar and fertilize the pistils in their struggles to free themselves from the sticky anthers.]

\section{ASCLEPIAS.}

Perennial herbs; stems erect or decumbent; leaves alternate, opposite or whorled; flowers in terminal or lateral umbels; calyx 5-parted, small, lobes acute; corolla rotate, deeply 5-parted, reflexed, crown of 5 hoods, each containing an incurved, horn-like appendage; anthers tipped with an inflexed membrane; pollen masses 10, each pair occupying the contiguous cells of adjacent anthers; follicles large, many-seeded, seeds flat, usually comose.

1. A. tuberosa L. Butterfly-ineed. Stem stout, erect or ascending, branched above, hirsute, very leafy, 1-2 ft. high; leaves alternate or the lower opposite, oblong to lanceolate or linear, acute at the apex, rounded or cordate at the base, short-petioled, pubescent; umbels numerous, corymbose, many-flowered; peduncles shorter than the leaves; pedicels erect, about 1 in. long, pubescent; corolla yellowish-orange, crown bright orange, hoods erect, longer than the slender horns, and twice as long as the stamens; follicles erect, fusiform, pubescent, seeds comose. June-August. Common on dry soil.

2. A. variegata L. White Mrlkweed. Stem stout, leafless and smooth below, leafy and pubescent in lines above; leaves opposite, the middle ones sometimes in 4's, petioled, ovate to obovate, cuspidate, smooth on both sides, pale beneath, edges slightly crenate; umbels 1-5, compact, pubescent, 1-2 in. long; pedicels erect, as long as the peduncles; corolla white, often purple at the base; hoods roundish, spreading, longer than the purplish gymnostegium, and a little longer than the thick, awl-pointed, incurved horn; follicles erect, downy, seeds comose. May-June. Dry, open woods.

3. A. amplexica ulis Michx. Pine-barren Asclepias. Stems recurved, ascending or decumbent, smooth and glaucous, 1-2 ft. long ; leaves opposite, very thick, ovate, obtuse at the apex, cordate and clasping at the base, veins white and prominent; umbels $3-6$, manyflowered; peduncles half the length of the leaves, longer than the slender pedicels; corolla ash-colored; hoods white, longer than the 
gymnostegium and the nearly straight horn; follicles ovate-lanceolate, seeds comose. April-May. Dry pine barrens.

4. A. Perennis Walt. Thin-Leaved Milkweed. Stem erect, branched, slender, shrubby at the base, pubescent in lines above, 1-3 ft. high ; leaves opposite, petioled, thin, lanceolate to oblong-lanceolate, tapering at each end, smooth, pale beneath; umbels few, longpeduncled, often corymbose; pedicels slender, shorter than the peduncles; flowers small, white; hoods erect or spreading, about the length of the gymnostegium and half the length of the erect, needleshaped horn; follicle erect, ovate-lanceolate, smooth, seeds $\frac{1}{2}$ in. long, without coma. May-July. On river banks and in muddy places.

\section{VINCETOXICUM.}

Perennial; stems twining ; leaves opposite, cordate, petioled; flowers in axillary umbels or corymbs; calyx 5-parted, the lobes spreading; corolla rotate, the tube very short, the lobes convolute in the bud; crown an entire or lobed ring, adnate to the throat of the corolla; stamens inserted in the base of the corolla, not appendaged; gymnostegium flattened, depressed; follicles inflated, smooth or armed with soft spines, seeds comose.

1. V. Gonocarpos Walt. Large-Leaved Vincetoxicum. Stem slender, smooth or pubescent, twining high, 10-20 ft. long; leaves ovate, abruptly acuminate at the apex, deeply cordate at the base, 3-6 in. long ; petioles 1-4 in. long ; umbels peduncled, severalflowered ; pedicels stout, spreading; flower buds conic ; corolla greenish-purple, lobes lanceolate, obtuse, 3-4 times as long as the calyx, pubescent within; crown many-lobed; follicles smooth, 3-5-angled, 3-4 in. long. June-August. In moist thickets.

2. V. Carolinense (Jacq.) Britt. Carolina Vincetoxicum. Stem slender, hirsute, twining, 8-15 ft. long; leaves ovate, acuminate at the apex, deeply cordate at the base, $3-7$ in. long; petiole $2-4$ in. long; umbels on peduncles as long as the petioles, 6-8flowered ; flower buds ovate; corolla dark purple, the oblong lobes puberulent without, smooth within; crown 5-lobed with a 2-cleft tooth in each sinus; follicles warty. May-July. In woods.

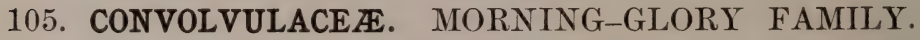

Annual or perennial herbs; stems usually twining or trailing, sometimes erect; leaves alternate, simple, exstipulate; 
flowers regular, perfect, axillary, solitary or cymose; calyx 5 -parted or 5-sepalous, usually persistent; corolla funnelform or salver-form, 5-angled or 5-lobed, convolute; stamens 5 , alternate with the lobes of the corolla, and inserted in its tube; ovary free, sessile, 2-3-celled with 2 ovules in each cell, or 4-6-celled with 1 ovule in each cell, styles 1-3, entire or 2-cleft; fruit a 1-6-seeded capsule.

\section{DICHONDRA.}

Perennial creeping herbs, rooting at the nodes; leaves cordate or reniform, petioled; flowers solitary, perfect, on bractless peduncles shorter than the leaves; calyx 5-parted, lobes narrowly obovate or spatulate; corolla rotate or open funnel-form, 5-lobed, shorter than. the calyx; stamens 5, included; ovary deeply 2-parted, 4-celled, styles 2, stigmas capitate ; fruit 2 distinct capsules, each 1-2-seeded.

D. evolvelacea (L.) Britt. Dichondra. Stems slender, pubescent, $6-15$ in. long; leaves deeply cordate or reniform, palmately veined; petiole $1-3$ in. long; flowers small, greenish-yellow, less than $\frac{1}{4}$ in. wide; peduncles slender, erect; calyx silky-pubescent, lobes of the corolla obovate or spatulate; capsule small, pubescent, seeds smooth. March-October. On damp soil.

\section{BREWERIA.}

Perennial trailing herbs; stem slender, pubescent; leaves entire, sessile or short-petioled; flowers small, on axillary peduncles longer than the leaves; sepals 5 ; corolla white or yellow, bell-shaped, hairy, 5-lobed or angled; stamens included; ovary 2-celled, 4-ovuled, styles 2, distinct or united below, stigmas peltate; fruit a 1-4-seeded capsule.

B. humistrata (Walt.) Gr. Breweria. Stem slender, pubescent or rough-hairy, branching, 1-3 ft. long; leaves oblong to elliptical, acute, obtuse or emarginate and mucronate at the apex, rounded or cordate at the base, pubescent; petiole short; peduncles very slender, 1-7-flowered, minutely bracted above; sepals ovate, usually smooth, fringed on the margins; corolla white; filaments hairy; style 2-cleft; capsule ovoid, as long as the calyx, mostly 1-seeded. May-September. In dry woods. 


\section{QUAMOCLIT.}

Annual herbs; stems slender, twining; leaves petioled, entire or pinnatifid; flowers solitary or clustered on axillary peduncles; sepals 5, short-awned or awnless ; corolla salverform, the tube long and somewhat enlarged above; stamens inserted in the base of the tube, exserted, filaments dilated below; ovary 4-celled, style 1, stigma globose, 2-lobed; fruit a 4-celled, 4-seeded capsule.

1. Q. Quamoclit (L.) Britt. Cypress Vine. Stem slender, smooth, twining high; leaves dark green, pinnatifid, the divisions linear, smooth; peduncles slender, as long as the leaves, 1-5-flowered; pedicels thickened upward; sepals ovate or oblong, mucronate; corolla bright scarlet or sometimes yellowish-white, salver-form, the tube $1-1 \frac{1}{2}$ in. long, the limb flat and spreading, $\frac{1}{2}-\frac{3}{4}$ in. wide; stamens and style exserted; capsule ovoid, twice the length of the sepals. May-October. Common in gardens.

2. Q. coccinea (L.) Moench. Small Red Morning-glory. Stems twining or trailing, smooth or pubescent ; leaves cordate, acuminate at the apex, basal lobes somewhat angled; petiole slender, nearly as long as the blade; peduncles 3-5-flowered, longer than the petioles; sepals awned; corolla salver-form, slightly lobed, scarlet, sometimes yellowish, 1 in. long; capsule globose, as long as the sepals. June-September. Usually in cultivated ground.

\section{IPOMGEA.}

Annual or perennial herbs; stems twining or trailing, or rarely erect; leaves from sagittate or cordate to nearly linear; flowers showy, white or purple, axillary, solitary, or in few-flowered cymes; sepals 5, sometimes unequal; corolla bell-shaped or funnel-form, 5-plaited and convolute in the bud, the limb entire, 5-angled or 5-lobed; stamens included, often unequal; ovary 2-4-celled, style slender, included, stigmas capitate, 2-lobed; fruit a 1-4-seeded capsule, seeds smooth or hairy.

1. I. Pandurata (L.) Meyer. Wild Potato Vine. Perennial, from a very large tuberous root; stem trailing or twining, smooth or slightly puhescent, $5-10 \mathrm{ft}$. long; leaves broadly cordate, with the apex slender and obtuse, sometimes fiddle-shaped or 3-lobed ; petioles slender ; peduncles longer than the petioles, 1-5-flowered; sepals oblong, obtuse, smooth, mucronate, the 2 outer ones shorter; corolla white 
with a purple throat, 2-3 in. wide, lobes pointed; capsule globose, 2-3-seeded, the seeds woolly on the angles. May-September. On dry or damp sandy soil.

2. I. tamifolia L. Blue Bindweed. Annual; stem at first stout and erect, becoming slender and twining above, hirsute, 1-6 ft. long; leaves cordate or ovate, acuminate, long-petioled, hairy ; peduncles longer than the petioles; flowers in crowded capitate cymes; bracts numerous, longer than the flowers; sepals subulate, bristly, as long as the corolla; corolla bright blue, $\frac{1}{2}$ in. wide; fruit a depressed, slightly 4-angled capsule, seeds rough. May-September. Common in cultivated ground.

3. I. Purpurea (L.) Roth. Morning-glory. Annual; stem twining high, pubescent with reflexed hairs; leaves cordate, entire, pubescent, long-petioled ; peduncles becoming elongated, 2-5 in. long, 1-5-flowered; pedicels twice the length of the calyx, reflexed in fruit; sepals lanceolate, pubescent; coroll.a 2 in. or more in length, white, blue, red or variegated, closing in sunshine; ovary 3-celled; capsule globose, shorter than the sepals. May-October. Common in cultivation.

4. I. sagittata Cav. Marsh Morning-glory. Perennial, from thick, fibrous roots; stem trailing, smooth, somewhat fleshy, 3-6 ft. long; leaves narrowly sagittate, basal lobes elongated, lanceolate or linear, smooth; peduncles shorter than the leaves, enlarged above, 1-3-flowered, bracts small; sepals oval, purple at the apex; corolla pink-purple, $2 \frac{1}{2}-3$ in. long; capsule ovoid, pointed, longer than the sepals, seeds silky on the angles. June-September. On damp soil, very common near the coast.

\section{CONVOLVULUS.}

Perennial herbs; stem twining, trailing or erect; leaves oval to cordate or sagittate, petioled; peduncles axillary, 1-few-flowered; flowers often with 2 large bracts at the base; sepals 5 , the 2 outer ones longer; corolla bell-shaped, 5-lobed or 5-angled; stamens included; style filiform, stigmas 2, oblong or linear; fruit a globose, 1-4-celled, 1-4-seeded capsule, seeds smooth.

C. sepium L. Bindweed. Stem smooth, slender, twining or trailing, 3-10 ft. long; leaves broadly sagittate or hastate, acute, the basal lobes spreading, obliquely truncate or angled, dentate or entire; petioles 1-2 in. long; peduncles 4-angled, longer than the petioles, 1-flowered; bracts cordate-ovate, keeled on the back; sepals acute; corolla white or pink, $1 \frac{1}{2}-2$ in. long. June-September. Common in cultivated fields. 


\section{POLEMONIACEAE. PHLOX FAMILY.}

Annual, perennial or slightly shrubby plants ; leaves opposite or alternate; flowers perfect, regular, solitary, cymose or paniculate; calyx 5-parted, the lobes scarious-margined; corolla rotate to funnel-form or salver-form, convolute in the bud, the limb 5-lobed or parted; stamens 5, inserted in the tube of the corolla and alternate with its lobes, filaments slender; ovary free, 3-celled, 3-many-ovuled, style single, filiform, 3-cleft; fruit a 3-celled, 3-valved, 3-many-seeded capsule, seeds angled.

\section{PHLOX.}

Perennial or rarely annual herbs; stems erect or diffuse; leaves opposite, or the upper alternate, entire, exstipulate; flowers showy, white or purple, in terminal cymes or panicles; calyx cylindrical or funnel-form, 5 -cleft, the lobes acute; corolla salver-form, the tube long and slender, the limb 5-parted, the lobes spreading, entire or obcordate; stamens included, unequal; ovary 3-celled, style slender; capsule ovoid, 3-celled, 1-few-seeded, seeds wingless or narrowwinged.

1. P. Paxiculata L. Garden Phlox. Perennial; stems in clumps, stout, erect, simple or branched above, $2-4 \mathrm{ft}$. high; leaves ovate-lanceolate to oblong, acuminate at the apex, rounded or cordate at the base, thin, smooth, veins prominent beneath; cymes numerous and compact, forming a pyramidal panicle; pedicels short; calyx teeth long, bristle-pointed: corolla purple to white, lobes round-obovate, shorter than the tube; capsule longer than the calyx tube. May-July. In rich woods; often cultivated.

2. P. pilosa L. Dowxy Phlox. Perennial; stem erect, slender, simple or branched, 1-2 ft. high; leaves linear-lanceolate to linear, distant, spreading, long-acuminate, sessile, stem and leaves pubescent or villous; cymes corymbose, loose; flowers short-pediceled; calyx glandular-viscid, the teeth shorter than the tube of the purple corolla, bristle-pointed; corolla tube pubescent, lobes obovate ; capsule twice the length of the calyx tube. April-May. In dry, open woods. 
3. P. Divaricata L. Wild Blue Phlox. Peremial; stems erect or ascending from a decumbent base, viscid-pubescent, $1 \mathrm{ft}$. high; leaves distant, lanceolate to oblong, acute at the apex, rounded at the base, sessile, pubescent; cymes corymbed, loosely flowered; calyx teeth subulate, longer than the tube; corolla bluish-purple, $\frac{1}{2}-\frac{3}{4}$ in. long, lobes notched at the apex, as long as the tube; capsule oval, shorter than the calyx teeth. April-May. In moist, open woods.

4. P. Drummondi Hook. Drummond's Phlox. Annual; stem erect or ascending, slender, weak, branching, glandular-pubescent, 6-12 in. high; leaves mostly alternate, lanceolate to oblong, pubescent, the upper clasping by a cordate base; corymbs loose; flowers rather long-pediceled; calyx tube short, the teeth lanceolate-setaceous, soon recurved; corolla purple to crimson or white, orifice of the tube usually with a white or yellowish star-like ring, lobes rounded at the apex; ovary 3 -seeded, angles of the seeds winged. April-June. Introduced from Texas and common everywhere in gardens.

\section{GILIA.}

Annual, biennial or perennial herbs; leaves opposite or alternate, entire or much divided; flowers solitary or clustered; calyx tubular or bell-shaped, 5-cleft; corolla tubular to salver-form, 5-lobed; stamens inserted evenly or unevenly, near the mouth of the tube, included or exserted; ovary 3-celled, 3-many-ovuled, style long, slender, stigma 3-lobed; fruit a 3-celled, 3-many-seeded capsule, seeds angled or compressed.

G. Rubra (L.) Heller. Scarlet Gilia. Biennial; stem erect, simple, smooth or pubescent, very leafy, 2-5 ft. high; leaves pinnately divided into filiform, acute segments; flowers very numerous in a long and slender panicle; calyx lobes setaceous-subulate, as long as the tube; corolla funnel-form, bright scarlet without, yellow spotted with red within, $1-1 \frac{1}{2}$ in. long, lobes acute, spreading, less than half the length of the tube; stamens slightly exserted; seeds with a loose, reticulated outer coat. June-September. Dry, sandy soil.

\section{POLEMONIUM.}

Perennial or annual herbs; stems erect or diffuse; leaves alternate, pinnately divided; flowers in a cyme or panicle; calyx bell-shaped, 5-cleft, becoming enlarged in fruit, the 
lobes as long as the tube; corolla rotate to bell-shaped, 5 -lobed; stamens 5, equally inserted in the throat of the tube, declined, filaments hairy at the base; ovary ovoid, ovules several; fruit a 3 -celled, several-seeded capsule, seeds angled.

P. reptans L. Greek Valerian. Perennial, from a short rootstock; stem smooth, weak, diffusely branched, 9-12 in. high; leaves petioled, odd-pinnate; leaflets $5-13$, ovate to elliptical, entire; corymbs peduncled, few-flowered ; flowers nodding, blue, $\frac{1}{2}$ in. wide; stamens white, included. April-May. Rich, shady woods.

\section{HYDROPHYLLACE AE. WATER-LEAF FAMILY.}

Annual, biennial or perennial herbs; leaves usually alternate, sometimes opposite, pinnately or palmately divided; flowers regular, perfect, solitary or in one-sided spikes or racemes; calyx 5-parted, persistent, often with reflexed appendages in the sinuses; corolla rotate to funnel-form or salver-form, 5-lobed; stamens 5, inserted in the base of the corolla and alternate with its lobes, filaments filiform, anthers versatile; ovary free, 1-celled with 2 parietal placentæ, or 2-celled, styles 2 , distinct or united; fruit a globose or oblong, 2 -celled, 2 -valved, few-many-seeded capsule, seeds angular, reticulated.

\section{HYDROPHYLLUM.}

Biennial or perennial herbs; stem erect, hairy or pubescent; leaves alternate, long-petioled; flowers in peduncled cymes, bractless; calyx tubular, 5-cleft, with linear appendages on the tube; corolla broadly tubular or campanulate, 5 -lobed, the lobes appendaged within; stamens 5, exserted, filaments hairy below; ovary hispid, 1-celled, with 2 thick fleshy placentæ, 4-ovuled, style single, 2-cleft; fruit a globose, 2-valved, 1-4-seeded capsule.

H. macrophyllum Nutt. Large-Leaved Water-leaf. Perennial, from a scaly rootstock; stems stout, erect, hairy, 2-3 ft. high; leaves pinnately divided or pinnatifid, the divisions irregularly 
toothed, the upper divisions larger; the lower leaves long-petioled, the upper nearly sessile; cymes simple or forked, compact; peduncle stout; pedicels short; calyx lobes longer than the tube, hispid; corolla nearly white; capsule hispid, globose, shorter than the calyx. April-June. In rich woods.

\section{NEMOPHILA.}

Annual; stems slender, decumbent, pubescent; leaves alternate or opposite, lobed or divided; flowers solitary, on peduncles opposite the petioles; calyx 5-parted, with reflexed appendages to the sinuses; corolla bell-shaped or tubular, 5-lobed, with 10 scale-like appendages at the base within; stamens 5, included; ovary hispid, 1-celled, placentæ 2, ovules 2-12; fruit a globose, 1-2-seeded capsule.

N. microcalyx (Nutt.) F. \& M. Small-flowered Nemophila. Stem very slender, diffusely branched, pubescent, becoming smooth with age, 3-18 in. long; leaves alternate, or the lower opposite, longpetioled, deeply 3-5-parted, the lobes obovate, toothed; flowers small, white, peduncles slender, shorter than the petioles; appendages of the calyx and corolla minute; capsule longer than the calyx, 1-2seeded, seeds bony. April-June. In shady woods.

\section{NAMA.}

Perennial herbs; stem glandular-pubescent or bristly; leaves alternate, entire, often with spines in the axils; flowers regular, perfect, axillary or terminal, solitary or clustered; calyx 5-parted or 5-sepalous; corolla bell-shaped, 5-parted; stamens 5, inserted on the base of the corolla, and alternate with its lobes, filaments dilated below ; ovary 2 -celled, manyovuled, styles 2, distinct, slender; fruit a globose, 2-celled, several-seeded capsule.

1. N. Quadrivalvis (Walt.) Kuntze. Hairy Nama. Stem ascending or erect, from a creeping base, pubescent or hispid, mostly simple, 1-3 ft. high; leaves lanceolate, acute at the apex, narrowed into a petiole below, pubescent on the veins beneath, axils spiny; flowers axillary, solitary or clustered, short-peduncled; calyx lobes linear, as long as the corolla; stamens included; capsule apparently 4-celled by the thickening of the placentæ, 2-valved, as long as the calyx. June-August. In muddy places. 
2. N. ovata (Nutt.) Britt. Ovate-leaved Nama. Stem erect, pubescent, spiny, simple or branched above, 2-3 ft. high; leaves ovate, short-petioled or the upper sessile, slightly pubescent; flowers blue, crowded at the ends of the branches; sepals lanceolate, hairy, shorter than the corolla; stamens and styles exserted; capsule shorter than the calyx. May-August. In wet soil.

\section{BORAGINACEAE. BORAGE FAMILY.}

Annual, biennial or perennial herbs, or rarely shrubs; leaves usually alternate, rough-hairy and entire, exstipulate; flowers perfect, usually in one-sided coiled spikes or racemes; calyx 5-parted, persistent; corolla 5-lobed, hypogynous, often appendaged in the throat; stamens 5 , inserted in the tube of the corolla and alternate with its lobes; ovary free, 2-celled, the cells deeply 2-lobed, making the ovary appear 4-celled, ovules 4 , style single; fruit usually 4 nutlets, each 1 -seeded.

\section{HELIOTROPIUM.}

Herbs or shrubs; leaves alternate, petioled, mostly entire; flowers white or blue, in one-sided scorpioid spikes; calyx lobes narrow ; corolla funnel-form or salver-form, not appendaged in the throat, the tube folded between the lobes; stamens included, filaments short or none; stigma conical; ovary 4-grooved, separable into 4 nutlets.

1. H. Curassavicum L. Seaside Heliotrope. Annual; stem succulent, glabrous and somewhat glaucous, diffusely branched, 6-18 in. long; leaves alternate or opposite, oblanceolate to linear, obtuse at the apex, narrowed below, entire, somewhat fleshy, the upper sessile and often fasciculate; spikes peduncled, often forked, densely flowered; flowers small, white, fading to blue, sessile, bractless; capsule globose, nutlets smooth; plant turning black in drying. May-September. In saline marshes.

2. H. Indicum L. Indian Heliotrope. Annual; stem erect, rough-hairy or hispid, branched, 1-3 ft. high; leaves ovate to oblong, obtuse or acute at the apex, rounded or cordate at the base, wavy on the margin, rugose, decurrent on the petiole; spikes seldom forked, hairy, densely flowered, becoming 4-9 in. long; calyx lobes lanceolate, shorter than the hairy tube of the blue corolla; capsule smooth, nutlets finally spreading. May-October. In waste places. 


\section{CYNOGLOSSUM.}

Biennial or perennial; stems pubescent or hispid; leaves alternate, the lower long-petioled, the upper sessile; flowers in panicled racemes; calyx 5-parted, enlarged and spreading in fruit; corolla funnel-form, with 5 obtuse scales closing the throat of the tube; stamens included; ovary 4-lobed, style slender; fruit 4 ovate nutlets which are covered with hooked or barbed bristles.

C. Virginicum L. Wild Comfrey. Perennial; stem stout, simple, erect, leafless above, $2-3 \mathrm{ft}$. high; leaves oval or oblong, the upper clasping by a cordate base; racemes bractless; flowers pale blue, on short pedicels which are recurved in fruit; nutlets not margined, separating and falling away at maturity. April-June. On dry soil.

\section{MYOSOTIS.}

Low annual, biennial or perennial herbs ; stems branching, erect or diffuse; leaves alternate, entire; flowers small, blue, pink or white, in elongated bractless racemes; calyx 5-cleft, the lobes erect or spreading in fruit; corolla salver-form, 5 -lobed, the tube as long as the calyx, the throat with 5 small appendages; stamens 5, inserted in the tube of the corolla, included; ovary 4-parted, style slender; nutlets smooth or pubescent, elliptical, compressed.

1. M. palustris (L.) Lam. Forget-me-not. Perennial, from slender rootstocks; stems slender, pubescent, rooting at the nodes, 6-15 in. long; leaves oblong to oblong-lanceolate, obtuse, narrowed to the sessile base, appressed-pubescent; racemes many-flowered; pedicels becoming elongated in fruit; lobes of the calyx shorter than the tube, spreading in fruit; corolla blue with a yellow eye; nutlets angled, smooth. April-July. Common in gardens and often naturalized.

2. M. Laxa Lehm. Small Forget-me-not. Annual or perennial; whole plant pubescent; stem slender, weak, decumbent and rooting at the base, 1-2 ft. long; lower leaves spatulate, the upper lanceolate; racemes loosely flowered, becoming elongated in fruit; pedicels spreading; calyx hispid, the lobes as long as the tube; corolla pale blue with a yellow eye; nutlets convex on all sides. May-July. On low ground. 


\section{LITHOSPERMUM.}

Annual or perennial herbs, mostly rough-hairy, and with red roots; leaves alternate, entire; flowers in leafy-bracted spikes or racemes; calyx 5-parted, the lobes narrow, equal; corolla funnel-form to salver-form, obtusely 5-lobed, smooth, crested or hairy in the throat; stamens 5, inserted in the tube of the corolla, included; ovary deeply 4-parted, style slender, stigma capitate or 2-lobed; nutlets 1-4, white and smooth or brown and wrinkled, truncate at the base.

1. L. Arvense L. Field Gromwell. Annual or biennial; rough with appressed hairs; stem erect, simple or branched from the base, 6-18 in. high; leaves lanceolate to linear, the lower obtuse at the apex and tapering into a short petiole, the upper acute and sessile; flowers scattering and sessile on the spikes; calyx lobes linear-subulate, as long as the yellowish-white, funnel-form corolla; nutlets brown, wrinkled and pitted, about one-half the length of the calyx. March-April. Fields and waste places.

2. L. Gmelini (Michx.) Hitch. Hairy Puccoon. Perennial; hispid with rigid hairs; stems usually clustered, erect, simple, or branched above, stout, 1-2 ft. high; leaves linear-lanceolate, obtuse, sessile, the lower often scale-like; flowers in leafy, terminal racemes; calyx lobes linear; corolla salver-form, orange-yellow, the tube $\frac{3}{4}$ in. long, twice the length of the calyx, hairy within, the lobes rounded, spreading, the throat crested ; nutlets white, shining, ovoid. AprilMay. In dry pine barrens.

\section{ONOSIMODIUM.}

Perennial, hispid herbs; stems stout; leaves alternate, entire, prominently veined; flowers greenish-white, on a terminal bracted spike or raceme; calyx 5-parted, lobes linear; corolla tubular, the 5 short, acute lobes connivent, tube 10-toothed within; stamens included, nearly sessile; style filiform, exserted, ovules 4 ; nutlets often only 1 or 2 , white, ovoid, smooth and shining, or pitted.

1. O. Carolinianum (Lam.) DC. Carolina Gromwell. Stem stout, erect, branching, rough with rigid white hairs, $2-4 \mathrm{ft}$. high; leaves ovate-lanceolate to oblong, acute at the apex, sessile, 5-9-ribbed; flowers pediceled, yellowish-white; calyx about half the length of the corolla, which is pubescent on the outside; nutlets dull 
white, about half the length of the calyx. May-June. In dry fields and thickets.

2. O. Virginianum (L.) DC. Virginia Gromwell. Stem erect, slender, sparingly branched above, rough with bristly hairs, 1-2 ft. high; leaves lanceolate to oblanceolate, obtuse at the apex, sessile; corolla yellowish-white, tubular, the lobes acute, nearly as long as the tube, bristly; nutlets white, shining, ovoid. May-June. In dry fields and woods.

\section{VERBENACEÆ. VERBENA FAMILY.}

Herbs or shrubs; stems 4-angled; leaves simple or compound, exstipulate; flowers perfect, terminal or axillary, in spikes, racemes or panicles; calyx 4-5-parted, persistent; corolla regular or 2-lipped, 4-5-lobed; stamens 2 , 4, or 5, inserted in the tube of the corolla; ovary free, 2-8-celled, 1 or 2 ovules in each cell, style simple, terminal; fruit dry and separating into several 1-seeded nutlets, or baccate.

\section{VERBENA.}

Annual or perennial herbs; leaves simple, opposite, serrate or pinnately lobed; flowers in terminal spikes which become much elongated in fruit; calyx tubular, 5-ribbed, 5-toothed; corolla salver-form or funnel-form, the tube often curved, bearded in the throat, limb spreading, 5-lobed, often somewhat 2-lipped; stamens 4 , didynamous, rarely only 2 , included; ovary 2-4-celled, 2-4-ovuled, style slender, 2-lobed; fruit 2-4 smooth or roughened, 1-seeded nutlets.

1. V. officinalis L. European Vervain. Annual; stem erect, slender, nearly or quite smooth, branching, 1-3 ft. high; leaves ovate to obovate in outline, pinnately lobed or divided, narrowed and entire toward the base, pubescent beneath; petioles margined; spikes several, very slender; flowers small, purple, bracts shorter than the calyx. June-September. In fields and waste places; introduced from Europe.

2. V. Angustifolia Michx. Narrow-leaved Vervain. Perennial, rough-hairy ; stem simple, or branched below, from a creeping base, 1-2 ft. high; leaves lanceolate to spatulate, obtuse and toothed at the apex, tapering to a sessile base; spike peduncled, 
slender, close-flowered; bracts about the length of the calyx ; corolla purple, tube slightly curved, $\frac{1}{4}$ in. long. June-September. In dry, open woods.

3. V. Canadensis (L.) Britt. Wild Verbena. Perennial; stem widely branched, diffuse, creeping at the base, pubescent, 6-15 in. long; leaves mostly 3-lobed or parted, the divisions irregularly cut and toothed, the base cuneate; petiole margined; spikes terminal, long-peduncled, at first capitate, becoming much elongated; bracts slender, shorter than the unequal, subulate calyx teeth; corolla showy, purple, $\frac{1}{2}-\frac{3}{4}$ in. broad, the lobes emarginate. April-July. On dry soil.

\section{LIPPIA.}

Perennial herbs; stems rooting at the joints; leaves simple, opposite or whorled; flowers in long-peduncled axillary and terminal spikes or heads; calyx small, 2-4-toothed; corolla tube straight or curved, the limb somewhat bilabiate, oblique; stamens 4, didynamous; ovary 2-celled, 2-ovuled, style short, stigma oblique; fruit 2 nutlets, each 1-seeded.

1. L. Lanceolata Michx. Fog-fruit. Stems slender, weak, decumbent or ascending, smooth or slightly pubescent, 1-2 ft. long ; leaves elliptical, acute and coarsely serrate above, the lower part of the leaf entire and narrowed to the short petiole or sessile base; peduncles slender, longer than the leaves; heads globose, becoming elongated, bracts acute; corolla pale blue, as long as the calyx. May-July. In damp places.

2. L. NODIfLORA (L.) Michx. Stem creeping or ascending, slightly pubescent, $6-18$ in. long; leaves spatulate to obovate, coarsely toothed above, cuneate and entire below, rough; peduncles 2-4 times as long as the leaves; heads globose, becoming elongated; flowers white or purple ; corolla about double the length of the calyx. MaySeptemiber. In wet places.

\section{CALLICARPA.}

Shrubs; leaves simple, petioled, opposite or whorled, glandular-dotted; flowers in axillary cymes; calyx 4-toothed or entire ; corolla funnel-form, 4-cleft, regular ; stamens 4, equal, exserted ; ovary 4 -ovuled, style slender, stigma capitate ; fruit a 1-4-seeded berry.

C. Americana L. French Mulberry. Shrubs, with stellate, glandular or scurfy pubescence, widely branched, 3-8 ft. high; leaves 
ovate to oblong, acute at each end, crenate-serrate, rough above, pubescent beneath, glandular-dotted; petioles slender; cvmes manyflowered, the peduncle as long as the petiole, pedicels short ; calyx cup-shaped, the teeth short; corolla double the length of the calyx, blue; fruit violet-purple, very conspicuous in autumn. May-July. Common in fields and thickets.

\section{VITEX.}

Shrubs; leaves palmately compound; flowers in panicled spikes; calyx short, 5-toothed; corolla cup-shaped, 5-lobed, somewhat bilabiate; stamens 4, unequal, exserted; ovary 4-celled, style slender; fruit a drupe.

V. Agnus-castus L. Chaste tree. Shrub, widely branched, 4-8 ft. high; leaflets 5-7, lanceolate, acute at each end, entire; spikes in terminal panicles, hoary-pubescent; flowers purple; corolla tube strongly curved; fruit a 1-seeded drupe or berry. April-June. Common in cultivation.

\section{LABIAT $\mathbb{E}$. MINT FAMILY.}

Herbs or shrubs, mostly aromatic; stems 4-angled; leaves opposite, simple, exstipulate; flowers perfect, more or less 2-lipped, axillary or terminal, often in dense whorls, sometimes solitary; calyx persistent, regular or 2-lipped, usually 5-toothed, often prominently striate; corolla bilabiate or rarely regular, limb 4-5-lobed, upper lip usually 2-lobed, the lower 3-lobed; stamens 2 or 4, inserted in the corolla tube; ovary free, 4-lobed, 4-ovuled, the slender style 2-lobed; fruit 4 nutlets, each 1-seeded.

\section{TEUCRIUM.}

Perennial herbs; stems erect; leaves entire or toothed; flowers in terminal spikes or axillary whorls; calyx tubular, unequally 5-toothed, 10-nerved; corolla tube short, limb 5 -lobed, the 4 upper lobes short, the lower larger, oblong, concave; stamens 4, didynamous, exserted between the 2 uppermost lobes of the corolla, the lower pair longer; style 2-cleft; nutlets rugose. 
T. Canadense L. Germander. Stem erect, simple or branched, tomentose, $1 \frac{1}{2}-3 \mathrm{ft}$. high; leaves lanceolate to ovate, acute at the apex, short-petioled, serrate, pubescent above, white-hoary beneath; flowers in dense hoary spikes which finally become much elongated in fruit, flower clusters usually alternate, bracted; calyx bell-shaped, pubescent, the 3 upper teeth short; corolla purplish, about $\frac{3}{4}$ in. long. June-September. On low ground.

\section{TRICHOSTEMA.}

Annual or perennial herbs; stems erect, branching; leaves entire; flowers in loose panicles or cymes; calyx short, the 3 lower teeth long, connate, the 2 upper short; corolla slender, the limb deeply 5-cleft; stamens 4 , didynamous, longexserted, filaments coiled; ovary deeply 4-lobed; nutlets pitted, united at the base.

T. pichотомим L. Blue Curls. Stem erect, slender, widely branched, viscid-pubescent or nearly smooth, 1-2 ft. high; leaves lanceolate to oblong, short-petioled, the upper small and bract-like; flowers in a spreading panicle, often 3 together; corolla blue to white, declined; stamens blue, very long. June-September. On dry soil.

\section{SCUTELLARIA.}

Perennial herbs with bitter juice; flowers in spike-like racemes or solitary in the axils; calyx 2-lipped, the lips entire, the upper with a prominent helmet-shaped protuberance on the back, deciduous, the lower persistent; corolla tube recurved-ascending, dilated at the throat, limb 2-lipped, the upper lip arched, entire or notched at the apex, middle lobe of the lower lip much the longest, spreading; stamens 4, didynamous, the upper pair shorter, anthers ciliate; ovary deeply 4-parted, style unequally 2-cleft; nutlets roughened.

S. Cordifolia Muhl. Heart-leaved Skullcap. Stem slender, erect, simple or branched, pubescent, 6-18 in. high; lower leaves long-petioled, cordate or ovate, often crenate, the upper sessile, linear or elliptical, entire, pubescent; racemes mostly solitary, bracts longer than the pedicels; flowers blue and white, about 1 in. long, the lips nearly equal. June-August. On dry soil. 


\section{GLECOMA.}

Perennial herbs; stems creeping, widely branched, ascending at the apex; leaves petioled, orbicular to reniform; flowers in axillary clusters; calyx tubular, oblique, equally 5-toothed; corolla tube enlarged above, upper lip 2-lobed, the lower 3 -lobed, the middle lobe longer, emarginate; stamens 4, didynamous, included; nutlets smooth.

G. Hederacea L. Ground Ivy. Stems pubescent, 6-18 in. long; leaves round-cordate, crenate, long-petioled; axillary clusters few-flowered ; calyx pubescent, the teeth short ; corolla blue or violet, at least twice the length of the calyx. March-May. On low ground near dwellings.

\section{SALVIA.}

Annual, biennial or perennial herbs, or sometimes shrubby ; - flowers in spikes, racemes or panicles, usually showy; calyx tubular or bell-shaped, not bearded in the throat, 2-lipped, the upper lip entire or 3-toothed, the lower 2-cleft; corolla 2-lipped, the upper lip entire or notched, the lower spreading, 3-lobed, with the middle lobe longer; stamens 2, short, anthers 2-celled, the upper cell fertile, the lower abortive; style 2-cleft; nutlets smooth.

1. S. lyrata L. Lyre-leaved Salvia. Biennial or perennial; stem erect, sparingly branched above, hirsute, 1-2 ft. high; leaves mostly basal, spreading, lyrate-pinnatifid, usually purple, stem leaves small, sessile or short-petioled ; racemes many-flowered, whorls about 6 -flowered; calyx teeth short on the upper lip, long and subulate on the lower; corolla blue or purple, the tube about 1 in. long, dilated upward. April-May. On dry soil.

2. S. officinalis L. Garden Sage. Stem shrubby, slender, much branched below, $1 \mathrm{ft}$. high; leaves grayish-green, lance-oblong, crenate, rugose; flowers in terminal spikes, whorls several-flowered; corolla blue, upper lip strongly arched, about equaling the lower. June-August. Introduced from Europe and a common garden herb.

3. S. Splendens Sell. SCARLet SaGe. Anuual; stem erect, smooth, widely branched, 2-3 ft. high; leaves long-petioled, ovate, acute at the apex, narrowed or truncate at the base, crenate; flowers in slender terminal spikes; calyx about $1 \mathrm{in}$. long, corolla twice as long, both bright scarlet. June-October. Introduced from Brazil and common in cultivation. 


\section{MONARDA.}

Annual or perennial herbs; stem usually tall ; leaves dentate or serrate; whorls capitate and axillary, dense-flowered; calyx tubular, bearded in the throat, nearly equally 5 -toothed; corolla nearly equally 2-lipped, the upper lip entire or emarginate, lower lip spreading, 3-lobed; perfect stamens 2, exserted, abortive stamens 2 ; nutlets smooth.

1. M. fistulosa L. Wild Bergamot. Perennial, aromatic; stem erect, slender, branched, pubescent, 2-4 ft. high; leaves ovate to lanceolate, acuminate at the apex, rounded at the base, sharply serrate, petioled; whorls terminal, subtended by several conspicuous white or pale purple bracts; calyx curved, densely hairy in the throat, teeth subulate; corolla pink to purple, slender, $1 \frac{1}{2}$ in. long, upper lip pubescent, entire. June-September. Dry hills and woods.

2. M. penctata L. Horse Mint. Perennial; stem stout, pubescent, much branched, 2-3 ft. high; leaves lanceolate to oblong, acute at each end, slightly serrate, short-petioled; whorls axillary and terminal, bracts orate to oblong, purplish ; calyx slightly hairy in the throat, teeth acute; corolla yellowish, 1 in. long, the upper lip pubescent, notched, the lower spotted with brown or purple. June-October. On dry soil.

\section{SOLANACE $\&$. POTATO FAMILY.}

Herbs or shrubs; juice often narcotic-poisonous; leaves alternate, exstipulate; flowers perfect, regular, axillary and solitary, or cymose; calyx usually 5-toothed or 5-cleft, persistent, often becoming much enlarged in fruit; corolla 5-10lobed, rotate to salver-form or tubular, the lobes often folded and convolute in the bud; stamens inserted in the tube of the corolla and alternate with its lobes; ovary 2-5-celled, style and stigma single; fruit a $2-5$-celled, many-seeded capsule or berry.

\section{PHYSALIS.}

Annual or perennial herbs; stems diffusely branched; leaves petioled, entire or toothed; flowers axillary, solitary, nodding; calyx 5 -toothed, becoming 5 -angled, much enlarged 
and enclosing the fruit; corolla campanulate, plaited, 5-lobed or 5-angled, yellowish, usually with a dark brown or purple center; stamens shorter than the corolla and inserted in its tube; ovary 2-celled, style slender, stigma obtuse, 2-lobed; fruit a juicy, many-seeded berry, enclosed in the membranaceous and reticulated calyx.

1. P. pubescens L. Hairy Ground Cherry. Annual; stem diffusely branched, 4-angled, with one side rounded, often swollen at the nodes, tomentose or villous with viscid hairs, or sometimes nearly smooth, 1-2 ft. high; leaves long-petioled, ovate, acuminate at the apex, rounded or slightly cordate and uneven at the base, wavymargined or entire, pubescent; calyx short in flower, with the teeth longer than the tube, becoming about 1 in. long in fruit, ovoid, retuse and sharply 5 -angled at the base; corolla about $\frac{1}{3}$ in. wide, bright yellow with a brown center; filaments hairy, anthers purplish; berry yellow or greenish. June-October. Common in waste places.

2. P. angulata L. Wild Ground Cherry. Annual; smooth throughout; stem sharply 4-angled, erect or decumbent, 1-4 ft. long ; leaves ovate, acute at the apex, obtuse or truncate and uneven at the base, sharply toothed, long-petioled; calyx lobes about as long as the tube in flower, fruiting calyx ovoid, 10-angled, reticulated with purple veins; corolla small, yellow; anthers purple; berry yellow, nearly as large as the calyx. June-August.

3. P. viscosa L. Sticky Ground Cherry. Perennial from a slender rootstock; stem at first erect, becoming diffuse and decumbent, angled, viscid-pubescent, 8-20 in. long; leaves ovate and irregular in outline, acute or obtuse at the apex, mostly rounded below, angular-toothed or entire, pubescence stellate, petiole $\frac{1}{2}-1$ in. long; peduncles longer than the petioles ; flowering calyx with lobes shorter than the tube, pubescent, fruiting calyx ovoid, 5-angled, truncate or slightly sunken at the base; corolla greenish-yellow, with a dark throat, about $\frac{3}{4}$ in. wide, obscurely lobed ; anthers yellow ; berry viscid, yellow or orange. June-October. On sandy soil.

\section{SOLANUM.}

Herbs or shrubs; stems often prickly, sometimes climbing; leaves alternate, often nearly or quite opposite ; flowers clustered, the peduncles often opposite or above the axils; calyx spreading, 5-toothed or 5-cleft, persistent; corolla rotate, 5 -lobed; stamens 5, exserted, the filaments very short, the 
anthers long and connivent about the style; ovary 2-celled, style slender; fruit a many-seeded, juicy berry.

1. S. nigrum L. Nightshade. Annual; stem smooth, or pubescent with simple hairs, erect, diffusely branched; branches wingangled, 1-3 ft. high; leaves ovate, irregularly toothed or entire, somewhat inequilateral, petioled; flowers in lateral, peduncled umbels, small, white, drooping; calyx lobes obtuse; corolla $\frac{1}{3}-\frac{1}{2}$ in. wide ; filaments pubescent; berries globose, smooth, black when ripe. June-September. Common in cultivated fields and waste places; poisonous.

2. S. Carolinense L. Horse Nettle. Perennial; stem erect, branched, pubescent with stellate hairs, armed with straight, yellow prickles, 1-3 ft. high; leaves ovate-oblong, deeply toothed or lobed, acute at the apex, abruptly contracted to the short petiole, prickly on the veins; racemes lateral, few-flowered; pedicels recurved in fruit; calyx lobes acuminate; corolla deeply angular-lobed, blue or white; berry globose, smooth, yellow. May-September. A common weed.

3. S. rostratum Dunal. Sand Bur. Annual; the whole plant beset with yellow prickles; stem erect, diffusely branched, 1-2 ft. high; leaves broadly oval or ovate in outline, deeply pinnately lobed or parted, petioled, pubescent with stellate hairs; racemes few-flowered; pedicels erect in fruit; calyx very prickly, becoming enlarged and enclosing the fruit; corolla bright yellow, 5 -angled, about 1 in. broad. May-September. Introduced from the west, and becoming a troublesome weed in some places.

4. S. tuberosum L. Irish Ротаto. Annual; stem diffusely branched, pubescent, underground branches numerous and tuberbearing; leaves irregularly pinnatifid and divided; flowers in cymose clusters, white or purple, with prominent yellow anthers; pedicels jointed; corolla 5-angled, $\frac{3}{4}-1$ in. broad ; fruit a globose, greenishyellow, many-seeded berry, about $\frac{1}{2}$ in. in diameter. March-October. Cultivated.

\section{LYCOPERSICON.}

Annual; stem diffusely branched ; leaves pinnately divided ; flowers in raceme-like clusters on peduncles opposite the leaves ; calyx 5-many-parted, persistent; corolla rotate, 5-6parted; stamens 5-6, inserted in the short tube of the corolla, filaments short, anthers elongated, connivent; ovary 2-several-celled, style and stigma simple; fruit a many-seeded berry. 
L. Lycopersicon (L.) Karst. Tomato. Stem diffusely branched and becoming decumbent, furrowed and angled below, viscid-pubescent, 3-5 ft. long; leaves irregularly lobed and pinnatifid, petioled; calyx lobes linear, about as long as the yellow corolla; fruit (in the wild state) globose or ovoid, red or yellow, $\frac{1}{4}-\frac{1}{2} \mathrm{in}$. in diameter, but greatly enlarged in cultivation. May-September. Common in cultivation and often spontaneous.

\section{LYCIUM.}

Shrubs or woody vines, often spiny; leaves entire, alternate, often fascicled; flowers solitary or clustered, terminal or axillary; calyx persistent, 4-5-lobed or toothed, not enlarged in fruit; corolla funnel-form or campanulate, the limb 4-5-lobed, the lobes obtuse; stamens 4-5, exserted; ovary 2-celled, style single, stigma obtuse; fruit a many-seeded berry.

L. vulgare (Ait.) Dunal. Matrimony Vine. Stem slender, branching, twining or trailing, 6-15 ft. long; branches angled, spiny; leaves elliptical, smooth, entire, sessile or short-petioled ; flowers solitary or few in the axils; peduncles long and slender; corolla spreading, greenish-purple, $\frac{1}{3}-\frac{1}{2}$ in. wide; berry oval, orange-red. April-July. Introduced from Africa, and often planted for covering trellises.

\section{DATURA.}

Annual or perennial, strong-scented herbs; stems tall and branching; leaves petioled, entire or lobed; flowers large, solitary in the forks of the branches; calyx tubular, 5 -toothed or lobed, the upper part deciduous, the lower persistent; corolla funnel-form, 5-angled, plaited, convolute in the bud; stamens 5 , inserted in the corolla tube; ovary 2-celled or imperfectly 4-celled, style filiform, stigma 2-lobed; fruit a spiny, 4-valved, many-seeded capsule.

1. D. Stramoniem L. Jimson-weed. Annual; stem smooth, green, stout, forking above, 1-4 ft. high ; leaves ovate to oblong-ovate, acute at the apex, narrowed at the base, sinuate-toothed, petioled; calyx 5-angled ; corolla white, about 4 in. long; capsule ovoid, erect, 2 in. long. May-October. A common weed; poisonous.

2. D. Tatula L. Purple Jimson-weed. Annual; stem erect, rather slender, slightly pubescent, purplish, 2-5 ft. high; leaves 
petioled, sinuate-toothed, often truncate or cordate at the base ; flowers purplish; very similar to the preceding species. May-October. Common and poisonous.

3. D. Metel L. Thorn-Apple. Annual; stem erect, stout, branching, glandular-pubescent, 3-6 ft. high; leaves ovate, acute at the apex, rounded or truncate at the base, entire or slightly toothed; calyx not angled, about 3 in. long; corolla white, 10-toothed, 6-7 in. long; capsule globose, nodding. June-September. Introduced from South America.

\section{SCROPHULARIACE E. FIGWORT FAMILY.}

Herbs, shrubs or trees ; leaves simple, opposite or alternate, exstipulate; flowers perfect, mostly complete, irregular ; calyx 4-5-toothed, persistent; corolla tubular, withering-persistent, often bilabiate, the upper lip 2-lobed or entire, the lower 3 -lobed; stamens $2-4$, rarely 5 , inserted on the tube of the corolla and alternate with its lobes; ovary free, 2-celled, with axial placentæ, style slender, curved, stigma thick, 2-lobed; fruit a 2-celled, many-seeded capsule.

Corolla rotate

I. Verbascum.

Corolla tubular, saccate at the base . . . . III. Antirrhinum.

Corolla tubular, spurred at the base . . . II. Linaria.

Corolla tubular or campanulate, not spurred or saccate.

Stamens 2

VIII. Leptandra.

Stamens 4.

Corolla bilabiate.

Sterile filament as long as the fertile stamens V. Pentstemon.

Sterile filament shorter than the fertile stamens IV. Chelone.

Sterile filament wanting . . . . . VII. Mimulus.

Corolla irregular, but not bilabiate.

Trees

VI. Paulownia.

Herbs.

Flowers pink, purple or white

X. Gerardia.

Flowers yellow

IX. Dasystoma. 


\section{VERBASCUM.}

Biennial; stem slender, erect; leaves alternate; flowers in spikes, racemes or panicles; calyx deeply 5-cleft; corolla rotate, 5-lobed, the lobes nearly equal; stamens 5, unequal, declined, some or all of the tilaments bearded; style flattened at the apex; fruit a globose capsule, seeds roughened.

V. Blattaria L. Мотн Muldein. Stem erect, slender, simple or sparingly branched, smooth below, pubescent above, 2-4 ft. high ; leaves oblong to lanceolate, acute at the apex, obtuse or truncate at the base, dentate to pinnately lobed, the lower petioled, the upper sessile and clasping; raceme long and loose, glandular-pubescent, pedicels bracted; corolla white or yellow, marked with brown on the back, about 1 in. wide; filaments all bearded with purple hairs; capsule longer than the calyx. April-July. Common in fields and waste places; naturalized from Europe.

\section{LINARIA.}

Annual, biennial or perennial; leaves mostly alternate on the flowering stems, often opposite or whorled at the base and on sterile stems, entire, dentate or lobed; flowers in bracted spikes or racemes; calyx 5-parted; corolla spurred at the base, upper lip erect, emarginate or 2-lobed, the lower lip spreading, 3-lobed, the throat nearly closed by a prominent palate; stamens 4 , didynamous, included; fruit a globose capsule opening at the base.

L. Canadensis (L.) Dumont. Toad-flax. Biennial; flowering stems erect, slender, rarely branched, smooth, 1-2 ft. high, sterile stems prostrate, with opposite or whorled leaves, $2-6$ in. long; leaves linear, entire, sessile; racemes erect, slender; pedicels erect, as long as the calyx ; corolla small, blue and white, the spur filiform, curved, longer than the pedicels; capsule 2-valved, the valves 3-toothed. April-May. On dry or cultivated ground.

\section{ANTIRRHINUM.}

Annual or perennial herbs; leaves alternate or sometimes opposite on sterile shoots; flowers axillary or in terminal racemes; calyx 5-parted; corolla saccate at the base, the 
upper lip erect, 2-lobed, the lower spreading, 3-lobed, the prominent palate nearly closing the throat; stamens 4 , didynamous, included; style filiform, its base often persistent; capsule globose to oblong, seeds smooth or roughened.

A. majus L. Snapdragon. Perennial; stem erect, smooth below, glandular-pubescent above, 1-2 ft. high; leaves linear to oblong-lanceolate, entire, smooth, sometimes fleshy, sessile or shortpetioled; flowers in a terminal raceme; pedicels short, stout, erect in fruit; corolla $1 \frac{1}{2}-2$ in. long, of many colors ; capsule oblique, the persistent base of the style bent forward. May-September. Common in gardens and often escaped.

\section{CHELONE.}

Perennial herbs; stem smooth; leaves opposite, serrate, petioled; flowers large, in dense, bracted spikes; calyx 5 -parted; corolla white or purple, inflated-tubular, the upper lip concave, emarginate, the lower spreading, woolly within, the middle lobe often shorter; stamens 5, one of them small and sterile, the anthers didynamous, filaments and anthers woolly; seeds broadly winged.

C. GLABRA L. SNAKE-HEAD. Stem erect, simple or branched, 4-sided, 2-3 ft. high; leaves lanceolate, acuminate, short-petioled, serrate, sometimes pubescent beneath; spike terminal, short, simple or branched, nearly sessile; bracts ovate; corolla white or pink, 1-1 $\frac{1}{2}$ in. long. June-September. Along streams.

\section{PENTSTEMON.}

Perennial; stem erect, rarely branched; leaves opposite, or the upper sometimes alternate; flowers white or purple, in terminal cymes or panicles; calyx 5-parted; corolla tube enlarged or inflated above, upper lip concave, emarginate or 2-lobed, the lower 3-lobed; stamens 5, included, declined at the base, 4 of the stamens anther-bearing and didynamous, the other sterile and usually bearded; style slender; capsule 2 -valved, seeds wingless.

1. P. hirsutus (L.) Willd. Hairy Beard-tongue. Stem erect, slender, pubescent, 18-24 in. high; lower leaves ovate to ovatelanceolate, long-petioled, the middle leaves oblanceolate, tapering to 
the base, the upper leaves lanceolate, sessile and clasping, all dentate or serrate, smooth or slightly pubescent; cymes loose, few-flowered, glandular-pubescent; pedicels short; corolla tube about 1 in. long; dilated above, 2-grooved below, the throat with a densely bearded palate; sterile filament densely bearded above. May-July. In open, dry woods.

2. P. Canescens Britt. Gray Beard-tongue. Stem erect, stout, pubescent, often several from the same root, 2-3 ft. high; lower leaves oval, the long petiole margined, upper leaves ovatelanceolate, sessile, all denticulate, slightly pubescent; cymes loose, pedicels short; corolla tube white to purple, about $1 \mathrm{in}$. long, throat smooth or slightly bearded; sterile stamen slightly bearded near the apex. May-July. In dry, open woods.

\section{PAULOWNIA.}

A tree having much the appearance of Catalpa; leaves opposite, long-petioled, entire or 3-lobed; flowers purple or violet, in large terminal panicles; calyx short, 5-cleft; corolla with a long tube which is spreading above, lobes spreading, nearly equal; stamens 4 , included, didynamous; style slender; fruit a dehiscent, ovoid capsule, seeds winged and striate.

P. tomentosa (Thumb.) Britt. Paulowria. A tree with gray bark and a rounded top; leaves ovate to 3-lobed, pubescent, 6-10 in. wide; flowers 2-3 in. long, in spreading panicles 2-3 ft. long; pedicels stout, tomentose; capsule coriaceous, dehiscent. April-May. Introduced from Japan. The panicles with the large flower buds are developed from September to ${ }^{*}$ November and are conspicuous during the winter months.

\section{MIMULUS.}

Perennial; stem erect or decumbent; leaves opposite; flowers axillary and solitary, mostly yellow or purple; calyx tubular, 5-angled, 5-toothed; corolla tube with 2 ridges within on the lower side, upper lip erect or reflexed, lower lip spreading; stamens 4, didynamous; style slender, 2-lobed; capsule 2-valved, many-seeded.

1. M. Ringens L. Square-stemued Monkey Flower. Stem 4-angled, erect, branched, smooth, 1-2 ft. high; leaves lanceolate to 
oblong, serrate, sessile or clasping at the base; peduncles slender, longer than the flowers; corolla riolet, about $1 \mathrm{in}$. long, lower lip puberulent within. June-September. Along streams and in wet places.

2. M. Alatus Soland. Sharp-winged Monkey Flower. Stem square, wing-angled, erect, smooth, 1-2 ft. high; leaves ovate to oblong, acuminate, serrate, short-petioled; peduncles shorter than the flowers; calyx teeth short; corolla violet, about 1 in. long. June-August. In swamps and wet places.

\section{LEPTANDRA.}

Perennial herbs; stems tall, stout; leaves opposite or verticillate; flowers in dense terminal or axillary peduncled spikes; calyx small, 4-parted; corolla tubular, 4-lobed, the lobes nearly equal; stamens 2, long-exserted; style long and slender, stigma capitate; capsule ovoid, 4-valved, seeds reticulated.

L. Virginica (L.) Nutt. C'clver's Root. Stem erect, smooth or slightly pubescent, simple or with few branches above, $2-5 \mathrm{ft}$. high; leaves $3-7$ in a whorl, lanceolate to oblong, acuminate at the apex, sharply serrate, smooth or sometimes pubescent beneath, shortpetioled; spikes solitary or several ; flowers bracted, small, white or purplish; stamens nearly twice the length of the corolla; capsule twice the length of the calyx. June-August. In meadows and open woods.

\section{DASYSTOMA.}

Coarse annual or perennial herbs; leaves opposite; flowers yellow, in terminal leafy racemes or panicles; calyx bellshaped, כ-lobed, the lobes often toothed; corolla tubular-bellshaped. woolly within, the limb spreading, 5-lobed, slightly irregular; stamens 4, included, didynamous, woolly, anthers awned at the base; style filiform, thickened at the apex; fruit an ovate, 2 -valved capsule.

1. D. Flava (L.) Wood. Dowry False Foxglove. Perennial ; stem erect, downy, mostly simple, 2-4 ft. high; leaves lanceolate to oblong, the lower pinnately lobed or pinnatifid, short-petioled, the upper nearly entire and sessile ; pedicels stout ; calyx lobes entire ; corolla $1 \frac{1}{2}$ in. long, smooth; capsule pubescent, twice the length of the calyx. June-September. In dry woods. 
2. D. Virginica (L.) Britt. Sмooth False Foxglove. Perennial; stem erect, branched, smooth and glaucous, 3-6 ft. high; leaves petioled, the lower twice pinnatifid, the others incised and cut, or the upper lanceolate and entire; calyx shorter than the pedicels, the lobes as long as the tube; corolla about 2 in. long, the tube rather slender; capsule oval, smooth, twice the length of the calyx. June-September. In rich woods.

\section{GERARDIA.}

Annual or peremnial herbs; mostly blackening in drying; leaves opposite or rarely alternate, narrow and entire; flowers usually showy, in the axils of the upper leaves; calyx campanulate, 5-toothed; corolla funnel-form or tubular-bellshaped, 5-lobed, the throat oblique; stamens 4, included, didynamous, the longer filaments and anthers woolly; style slender, flattened and dilated above; capsule globose; seeds angled. Mostly flowering late in the season.

1. G. innifolia Nutt. Flax-Leaved Gerardia. Perennial; stem very slender, erect, branched, smooth, 2-3 ft. high; leaves erect, narrowly linear, the upper bract-like; peduncles about as long as the leaves; calyx truncate, with minute teeth; corolla purple, about $1 \mathrm{in.}$ long, the lobes nearly equal, rounded, fringed; filaments villous; eapsule globose, longer than the calyx. August-September. Dry pine barrens.

2. G. purperea L. Purple Gerardia. Annual; stem erect, slender, smooth or slightly rough, branched above, 1-3 ft. high; leaves linear, spreading, rough ; pedicels stout, as long as the calyx ; corolla purple to white, about $1 \mathrm{in}$. long and wide, the lobes minutely fringed, pubescent within; capsule longer than the calyx. AugustSeptember. On low ground.

\section{LENTIBULACE E. BLADDERWORT FAMILY.}

Annual or perennial herbs growing in water or in muddy places; leaves in a rosulate basal tuft and entire, or floating and dissected; scapes erect; flower's perfect, irregular, solitary or racemed; pedicels bracted; calyx 2-lipped, 2-5-lobed or parted; corolla 2-lipped, spurred at the base, upper lip erect, entire or 2-lobed, lower lip spreading or reflexed, 3-lobed, 
throat with a prominent palate; stamens 2 , included; ovary free, 1-celled, ovoid, style short, stigma 2-lobed; fruit a globose, many-seeded capsule, seeds roughened.

\section{UTRICULARIA.}

Annual or perennial; floating in still water by means of numerous small air bladders attached to the finely dissected leaves, or growing in wet soil with entire leaves and few or no air bladders; scapes 1-many-flowered; calyx lips entire; corolla with the upper lip entire, the lower larger and 3-lobed, the throat usually bearded within and nearly closed by the palate.

1. U. Cornuta Michx. Horned Bladderwort. Acaulescent; leaves linear and entire or none; air bladders few or none; scape erect, stout, 2-5-flowered, 8-12 in. high; flowers yellow, fragrant, $\frac{3}{4}$ in. wide; pedicel as long as the calyx; the lips of the corolla obovate, unequal, the lower longer, abruptly pointed, the sides reflexed, as long as the horn-shaped, curved spur, throat bearded; seeds minutely pitted. May-August. In swamps and muddy places.

2. U. subulata L. Small Bladderwort. Scape filiform, 2-6 in. high; leaves few and setaceous or none; air bladders few or none; racemes zigzag, 1-6-flowered; pedicels much longer than the calyx; corolla yellow, $\frac{1}{4}$ in. wide, the lower lip 3-lobed, longer than the appressed, conical, green-pointed spur. February-May. Wet, sandy soil.

3. U. inflata Walt. Swollen Bladderwort. Perennial; stem very slender, floating; lower leaves scattered, finely dissected, upper leaves whorled, finely dissected; the petioles dilated upward and inflated, air bladders very numerous; scape stout, 6-12 in. high, $3-10$-flowered; corolla yellow, about $\frac{3}{4}$ in. wide, upper lip ovate, slightly lobed, lower lip 3-lobed, twice the length of the curved, emarginate spur; fruit nodding. March-June. In ponds and still water.

\section{PINGUICULA.}

Perennial, acaulescent herbs; leaves in a rosulate, basal cluster, entire, margins involute, surface covered with a sticky secretion; scapes naked, circinate, 1-flowered; calyx 2-lipped, the upper lip 2-lobed, the lower 3-lobed; corolla 2-lipped, the 
upper lip 2-lobed, the lower 3-lobed and saccate or spurred at the base, palate hairy; capsule 2- or 4-valved.

1. P. Lutea Walt. Yellow Marsh Violet. Leaves viscidpubescent, yellowish-green, oblong-obovate, acute, coarsely cellular and very watery; scape $6-12 \mathrm{in}$. high; flower $1-1 \frac{1}{2} \mathrm{in}$. wide, bright yellow, nodding; spur slender, half the length of the rounded lobes of the corolla. February-April. Marshes in pine barrens.

2. P. elation Michx. Purple Marsh Violet. Leaves ovate to spatulate, acute, coarsely cellular and watery, clammy-pubescent; scape villous near the base, slender, 8-12 in. high; calyx glandular; corolla purple or blue, 1 in. wide, the rounded lobes very unequal, the spur obtuse. March-April. Wet, sandy soil.

\section{BIGNONIACEAE. BIGNONIA FAMILY.}

Trees, shrubs or woody vines; leaves simple or compound, opposite or alternate, exstipulate; flowers showy, in terminal or axillary clusters, perfect, somewhat irregular; calyx 2-lipped and 5-lobed, or truncate and entire; corolla funnelform or tubular, 2-lipped, 5-lobed; stamens 2 or 4 and didynamous, inserted in the tube of the corolla; ovary 2-celled, many-ovuled, style slender, stigma 2-lobed; fruit a 2 -valved, 2- or 4-celled, many-seeded capsule.

\section{BIGNONIA.}

Woody vines; leaves opposite, compound, usually tendrilbearing; flowers large, in axillary clusters ; calyx cup-shaped, truncate or undulate-toothed; corolla spreading-tubular, somewhat 2-lipped, the lobes rounded; stamens 4 , didynamous; capsule linear, flattened parallel with the partition, the 2 valves separating from the partition at maturity; seeds flat, broadly winged.

B. Crucigera L. Cross-vine. Stem climbing high, a transverse section of the older stems showing a conspicuous cross formed by the 4 medullary rays; branches glabrous; leaves evergreen, petioled; leaflets 2 , ovate, acuminate with a blunt apex, cordate at the base, entire, stalked, upper leaflets transformed into branching tendrils; flowers numerous, short-peduncled; corolla 2 in. long, 
reddish-brown without, yellow within; capsule 6 in. long, flat, the valves with a prominent central nerve; seeds broadly winged on the sides, short-winged on the ends. March-April. Common in woods.

\section{TECOMA.}

Woody vines, climbing by aërial rootlets ; leaves compound, odd-pimnate; flowers large, in terminal clusters; calyx bellshaped, unequally 5-toothed; corolla funnel-form, enlarged above the calyx, 5-lobed, slightly 2-lipped; stamens 4, didynamous; capsule slender-fusiform, slightly compressed contrary to the partition, 2-valved, dehiscent; seeds winged.

T. Radicans (L.) DC. Trumpet Flower. Stems climbing high by numerous rootlets, bark shreddy ; leaves deciduous, petioled ; leaflets 9-11, ovate to ovate-lanceolate, serrate, short-stalked, smooth or slightly pubescent; flowers in short, terminal racemes or corymbs ; calyx tubular, $\frac{3}{4}$ in. long; corolla $2-3$ in. long, scarlet without, yellow within, the lobes spreading; capsule $5-6$ in. long, curved, often persistent through the winter; seeds broadly winged. May-June. On borders of fields and in woods.

\section{CATALPA.}

Small trees; leaves opposite, simple, petioled, deciduous; flowers large and showy, in terminal panicles; calyx irregularly 2-lipped; corolla tubular-bell-shaped, oblique, 5-lobed, 2-lipped; fertile stamens 2, sterile stamens 3 , short; fruit a linear, 2-valved, many-seeded capsule; seeds winged.

C. Catalpa (L.) Karst. Catalpa. A small tree with thin, rough, gray bark and light, soft, but exceedingly durable wood; leaves long-petioled, cordate, entire or palmately 3-lobed, acuminate at the apex, palmately veined, pubescent; branches of the panicle in 3 's ; flowers large, $1-1 \frac{1}{2}$ in. long, white, variegated with yellow and purple; corolla lobes undulate or crisped; capsule very slender, $1 \mathrm{ft}$. or more in length, pendulous; seeds with long, fimbriate wings. April-June. On margins of rivers and swamps.

\section{MARTYNIACE $Æ$ UNICORN-PLANT FAMILY.}

Herbs ; leaves entire, petioled, the lower opposite, the upper alternate; flowers perfect, irregular, in terminal racemes; 
calyx 4-5-cleft or parted, often split to the base on one side; corolla spreading, tubular, oblique, 2-lipped, 5 -lobed, the lobes nearly equal and spreading; fertile stamens 2 or 4 ; ovary 1-celled, but often becoming 2- or 4-celled by the intrusion of the parietal placentæ, style slender, stigma 2-lobed; fruit a 2 -valved, woody capsule beaked by 2 long and recurved horns, seeds numerous.

\section{MARTYNIA.}

Characters of the family.

M. Louisiana Mill. Unicorn Plant. Annual herbs, densely viscid-pubescent; stem stout, diffusely branched, becoming decumbent, $2-4 \mathrm{ft}$. long; leaves round-cordate, undulate or entire; petiole long and stout; racemes short, few-flowered; calyx 5-cleft, with 2 or 3 bracts at the base; corolla $1 \frac{1}{2}-2 \mathrm{in}$. long, whitish, tinged with yellow and purple, tube somewhat curved ; capsule 5-6 in. long, crested on one side, shorter than the divergent, recurved horns. JuneAugust. In waste places.

\section{ACANTHACE E. ACANTHUS FAMILY.}

Herbs; stems usually 4-sided, often swollen between the joints; leaves simple, opposite, exstipulate; flowers usually axillary, perfect, often irregular, bracted; calyx 4-5-parted, persistent; corolla 5-lobed, often 2-lipped; fertile stamens 2 or 4 , inserted in the tube of the corolla; ovary free, 2-celled, few- or many-seeded, style filiform, stigma entire or 2-lobed; fruit a 2-celled, few-many-seeded capsule which is dehiscent by 2 elastic valves, seeds globose or flattened, not winged.

\section{RUELLIA.}

Perennial herbs; stems swollen at the joints and often between them, somewhat 4-angled; leaves sessile or shortpetioled, mostly entire ; flowers axillary, solitary or clustered, showy, white, blue or purple; calyx 2-bracted, 5-parted, the 
divisions linear and subulate; corolla tube slender, often much elongated, the limb spreading, nearly equally 5-lobed; stamens 4, didynamous, included or slightly exserted; style slender; capsule slender, narrowed below, 4-12-seeded.

1. R. strepexs L. Sмоoth Rueldia. Stem erect, slender, usually simple, smooth or hairy, 1-3 ft. high ; leaves ovate to oblong, acute at the apex, narrowed below into a short petiole ; flowers solitary or in small clusters, sessile or short-peduncled; calyx lobes shorter than the tube of the corolla, pubescent or ciliate; corolla blue, the tube $1 \frac{1}{2}-2 \mathrm{in}$. long, the limb $1-1 \frac{1}{2}$ in. wide ; capsule usually longer than the calyx, smooth, 8-12-seeded; the later flowers often without a corolla. May-September. On rich, dry soil.

2. R. ciliosa Pursh. Hairy Ruelia. Stem erect, rather stout, often few-branched above, hirsute with white hairs, 4-30 in. high; leaves oblong to ovate, acute or obtuse at the apex, narrowed and mostly sessile at the base, ciliate; flowers pale blue, solitary or 2-3 together; calyx lobes setaceous, half the length of the corolla tube; tube of the corolla $2 \mathrm{in.}$ long; capsule shorter than the calyx, smooth, 8-12-seeded; a very variable species, the flowers often without a corolla. June-September. In dry woods and fields.

\section{DIANTHERA.}

Perennial herbs; stem smooth; leaves opposite, entire or dentate; flower's axillary, solitary or clustered, irregular; calyx 5-parted; corolla bilabiate, upper lip erect, concave, entire or emarginate, the lower prominently veined, spreading, 3-lobed; stamens 2, inserted in the throat of the corolla; ovary 2-celled, 4-ovuled, style simple, acute; capsule flattened, narrowed below into a stipe.

1. D. Americaya L. Water Wrllow. Stem erect, slender, 2-3 ft. high; leaves lanceolate to linear-lanceolate, acuminate at the apex, narrowed below to the sessile or short-petioled base; flowers bracted, in short spikes, on peduncles as long as the leaves; corolla pale blue or purple, the tube as long as the lips, lower lip rugose; capsule about the length of the calyx. Mav-August. In water.

2. D. ovata Walt. Loose-Flowered Water Willow. Stems erect or ascending from a creeping base, slender, simple, 4-12 in. high; leaves ovate to lanceolate, sessile or short-petioled; spikes few-flowered, on peduncles shorter than the leaves; calyx lobes subulate; corolla less than $\frac{1}{2}$ in. long, pale purple, the lower lip with darker veins; capsule longer than the calyx. Nay-August. On muddy banks. 


\section{PLANTAGINACE $巴$. PLANTAIN FAMILY.}

Acaulescent herbs from fibrous roots; leaves basal, prominently veined; scape erect, bearing a terminal spike or head of small, perfect, polygamous or dicecious flowers; calyx of 4 scarious-margined, persistent sepals ; corolla rotate or salverform, the tube short, the limb 4-parted, scarious; stamens 2 or 4 , included or exserted, inserted in the tube of the corolla and alternate with its lobes, filaments slender, anthers versatile; ovary free, 2- or 4-celled, style slender; fruit a 2-celled, few- or many-seeded capsule, dehiscence circumscissile.

\section{PLANTAGO.}

Characters of the family.

1. P. major L. Plantain. Perennial, from a very short rootstock; leaves ovate to oval, strongly 5-9-ribbed, acute or obtuse at the apex, rounded at the base into a long, concave petiole, entire or toothed, smooth or slightly pubescent; scape taller than the leaves, pubescent, spike densely flowered; bracts short, ovate; flowers perfect; stamens 4, exserted; capsule ovoid, about twice the length of the calyx. April-August. Common in dooryards.

2. P. Lanceolata L. Ribgrass. Biennial or perennial; villous or nearly smooth; leares numerous, lanceolate to elliptical, acute, long-petioled, strongly 3-5-ribbed, entire or toothed; scapes much longer than the leares, striate-angled, $1-2 \mathrm{ft}$. high, spike short and dense; bracts and sepals ovate; corolla glabrous ; capsule longer than the calyx, 2-seeded. Narch-October. Introduced; common in meadows.

3. P. Aristata Michx. Large-bracted Plantain. Annual; leaves broadly linear, entire or sparingly denticulate, narrowed below into a margined petiole, smooth or silky-pubescent; scape longer than the leaves, $6-10 \mathrm{in}$. high, spike deuse; bracts linear, $\frac{1}{2}-1 \mathrm{in}$. long; stamens 4 ; capsule 2-seeded, longer than the calyx. AprilSeptember. Common on dry soil.

4. P. heterophylla Nutt. Maxy-seeded Plantais. Annual; leares linear, fleshy, entire or with a few spreading teeth, smooth or slightly pubescent; scapes slender, 3-6 in. high, spike very slender, many-flowered, the lower flowers often scattered; bracts ovate, longer than the sepals; stamens 2; capsule twice the length of the calyx, many-seeded. March-May. Common in cultivated ground. 


\section{RUBIACE E. MADDER FAMILY.}

Herbs, shrubs or trees; leaves simple, opposite or whorled; flowers perfect, regular, axillary or terminal; calyx tube adherent to the ovary, the limb 4-6-toothed or wanting; corolla rotate to funnel-form, 4-6-lobed, inserted in the throat of the calyx; stamens inserted in the throat of the corolla, as many as its lobes and alternate with them ; ovary 1-several-celled, style single; fruit a capsule, drupe or berry.

\section{HOUSTONIA.}

Annual, biennial or perennial herbs ; stems erect or diffuse ; leaves entire, stipules often only a line connecting the bases of opposite leaves ; flowers small, solitary or clustered ; calyx 4-toothed, persistent; corolla rotate to funnel-form, 4-lobed; stamens 4 ; ovary 2 -celled, style slender, stigmas 2 ; fruit a 2-celled, few-many-seeded capsule, dehiscent at the apex, which is free from the calyx.

1. H. cervlea L. Bluets. Perennial, from very slender rootstocks ; stems tufted, erect, smooth, forking, 3-6 in. high ; leaves sessile, often ciliate, the lower spatulate, the upper lanceolate; flowers solitary, on slender, axillary peduncles; calyx small; corolla salverform, blue or white, yellow in the throat; flowers of two forms, the stamens exserted and the style short in one form, while in the other the stamens are short and the style exserted; capsule laterally compressed, 2-lobed, shorter than the calyx. February-April. Common on open ground.

2. H. mixor (Michx.) Britt. Small Bluets. Annual; stem erect, branched at the base, forking above, smooth, 2-4 in. high; lower leaves oval to ovate, petioled, the upper narrower and sessile; flowers solitary, on slender, axillary peduncles, blue or white; calyx small; lobes of the corolla about as long as the tube; stamens and style exserted or included; capsule compressed, as long as the calyx. February-April. Common on dry, open ground.

3. H. purpurea L. Large Bluets. Perennial; stem stout, erect, simple or branched, smooth or pubescent, 4-angleds 6-12 in. high ; leaves ovate to ovate-lanceolate, sessile or short-petioled, 3-5nerved, often ciliate on the margins; flowers in terminal cymes, purple to nearly white; corolla funnel-form, the tube longer than 
the limb, hairy within; stamens and style exserted or included; capsule compressed-globose, much shorter than the calyx. May-July. In dry, open woods.

4. H. Longifolia Gaertn. Long-Leaved Bluets. Perennial; stem erect, branched, smooth, 4-angled, 8-12 in. high; leaves sessile, the lower oblanceolate or spatulate, the upper linear, 1-nerved ; corymbs terminal, few-flowered; corolla light purple to white, the lobes much shorter than the tube; capsule compressed-globose, nearly as long as the calyx. May-July. In dry, open woods.

\section{CEPHALANTHUS.}

Shrubs; leaves opposite, entire, short-petioled, stipulate; flowers white, in axillary, long-peduncled heads ; calyx obconic, 4-lobed; corolla tubular, 4-lobed; stamens 4, filaments short; ovary 2-celled, 2-ovuled, style slender, exserted, stigma capitate; fruit dry, obconical.

C. occidentalis L. Button-Bush. A branching shrub, 5-10 ft. high, young branches pubescent; leaves ovate-oblong, acute at each end, smooth or pubescent; stipules triangular; peduncles nearly as long as the leaves; heads globose, about 1 in. in diameter; style twice the length of the corolla; ovary much shorter than the calyx. June-August. Common on wet ground.

\section{MITCHELLA.}

Perennial; stem very slender, woody, creeping; leaves entire, petioled, stipulate, evergreen; flowers in pairs on axillary or terminal peduncles; calyx 4-lobed; corolla funnelform, 4-lobed, hairy within; stamens 4, alternate with the lobes of the corolla; ovary 4-celled, 4-ovuled, stigmas 4 ; stamens included and style exserted, or stamens exserted and style included; fruit 2 united, 4 -seeded drupes or berries.

M. Repens L. Twin-berry. Stem rooting at the joints, smooth, 1-2 ft. long; leaves broadly ovate to cordate, dark green, shining above; stipules minute; peduncles shorter than the leaves; flowers white, the buds tinged with pink, $\frac{1}{2}$ in. long; fruit bright red, "twoeyed" above by the remains of the calyces, persistent through the winter, edible. March-May. In rich, damp woods. 


\section{DIODIA.}

Annual or perennial herbs ; stems diffuse; leaves opposite, sessile, the sheathing stipules bristly fringed; flowers axillary, solitary or in small clusters; calyx 2-4-lobed, persistent; corolla funnel-form to salver-form, usually 4-lobed; stamens 4, exserted; ovary 2-celled, style slender, exserted, stigmas 2 ; fruit dry and indehiscent or somewhat fleshy, 2-celled, 2-seeded, seeds bony.

1. D. teres Walt. Poverty-Weed. Annual; stem erect or diffuse, much branched from the base, bristly or hairy, somewhat 4-angled, 6-18 in. high; leaves linear to linear-lanceolate, acute, sessile, rough, the margins revolute; flowers purplish; corolla funnelform, $\frac{1}{4}-\frac{1}{3} \mathrm{in}$. long; fruit obovoid, crowned with the persistent calyx lobes. June-September. On dry, barren soil.

2. D. Virginiana L. Large Poverty-weed. Perennial; stem widely branched, smooth or hispid, 4-angled, diffuse and often prostrate, 1-4 ft. long; leaves lanceolate, acute, sessile, somewhat fleshy; flowers white or purplish, solitary or few together; corolla tube very slender, $\frac{1}{3} \mathrm{in}$. long, the lobes spreading, hairy within ; fruit ovoid, strongly ribbed, dry or slightly fleshy, crowned with the 2-4persistent calyx teeth. June-September. On wet, sandy soil.

\section{GALIUM.}

Annual or perennial herbs; stems slender, 4-angled; leaves verticillate; flowers small, in axillary or terminal cymes or panicles, perfect or rarely diœcious ; calyx tube short, the teeth minute or wanting; corolla rotate, 3-4-lobed; stamens 3-4, short; ovary 2 -celled, styles 2 , short, united below ; fruit 2 united, indehiscent, 1-seeded carpels, sometimes fleshy.

1. G. Aparine L. Goosegrass. Annual; stem weak, decumbent, sharply 4 -angled and retrorsely hispid, widely branched, 2-4 ft. long; leaves 6-8 in a whorl, oblanceolate, hispid on the margins and mid-rib; peduncles axillary, longer than the leaves, 1-3-flowered; flowers white; fruiting pedicels erect; fruit dry, covered with hooked bristles. April-September. In waste places.

2. G. Pilosum Ait. Hairy Bedstraw. Stem rigid, erect or ascending, hairy or roughened on the angles, branched, 1-3 ft. long; leaves 4 in a whorl, small, oval, acute, rough-hairy, and punctatedotted; peduncles several times forked, ultimate branches 1-3-flow- 
ered; flowers greenish-purple; pedicels erect; fruit dry, densely bristly. May-September. On dry soil.

3. G. Circezans Michx. Wild Licorice. Perennial; stems several, erect, smooth or pubescent, 12-18 in. high; leaves 4 in a whorl, oval to ovate, obtuse at the apex, strongly 3 -nerved, pubescent; cymes long-peduncled, repeatedly branched; flowers nearly sessile, greenish-purple; pedicels at length recurved; fruit with hooked bristles. May-August. In dry, open woods.

4. G. hispidulum Michx. Bedstraw. Peremnial, from yellow roots; stems diffusely branched, smooth or slightly roughened, pubescent at the joints, erect or decumbent, 1-2 ft. long; leaves 4 in a whorl, narrowly oval, acute, rough on the margins and mid-vein; peduncles 1-3-flowered; flowers white; pedicels becoming reflexed; fruit a bluish-black, roughened berry. May-September. On dry, sandy soil.

\section{CAPRIFOLIACE E. HONEYSUCKLE FAMILY.}

Trees, shrubs, woody vines or herbs ; leaves opposite, simple or pinnately compound, exstipulate, deciduous or evergreen; flowers perfect, regular or irregular, mostly in terminal cymes ; calyx tube adherent to the ovary, 3-5-lobed; corolla rotate to tubular or urn-shaped, 3-5-lobed, sometimes bilabiate; stamens inserted in the tube of the corolla and alternate with its lobes; ovary 2-5-celled, ovules 1 in each cell, style slender, capitate or 2-5-lobed; fruit a 1-6-celled capsule, drupe or berry.

\section{SAMBUCUS.}

Shrubs; leaves pinnately compound; flowers white, regular, in large, terminal cymes; calyx tube ovoid, minutely $3-5$-toothed or truncate; corolla rotate, 3-5-lobed; stamens 5 , inserted in the base of the corolla; ovary $3-5$-celled, style short, 3-parted ; fruit berry-like, mostly 3-celled.

S. Canadensis L. Elder. A branching shrub 6-10 ft. high; stem weak, pith very large; leaves odd-pinnate; leaflets $7-11$, ovate to oval, acuminate at the apex, rounded at the base, short-stalked, serrate, smooth or slightly pubescent; cymes broad, flat-topped, 5-rayed; flowers small; fruit purplish-black. May-July. Common on low ground and along fences. 


\section{VIBURNUM.}

Shrubs or small trees; leaves simple, entire, dentate or lobed, stipulate or exstipulate; flowers small, white, in terminal cymes, the outer flowers of the cyme sometimes greatly enlarged and sterile; calyx tube very small, 5 -toothed; corolla rotate or campanulate, 5-lobed; stamens 5 , inserted in the tube of the corolla; ovary 1-3-celled, 1-3-ovuled but only 1 ovule maturing, style short, 3-lobed; fruit a 1-seeded drupe.

1. V. acerifolium L. Maple-leaved Arrow-wood. A slender shrub 3-6 ft. high; leaves broadly ovate to cordate, palmately veined and 3-lobed, serrate or nearly entire, petioled, pubescent, becoming smooth above; cymes peduncled, about 7-rayed, 2-3 in. wide; sterile flowers none; fruit oval, black, stone flat, 2-ridged on the edges. May-June. In dry, open woods.

2. V. dentatum L. Arrow-wood. A shrub 8-15 ft. high; leaves broadly ovate to oval, acute at the apex, rounded or cordate at the base, coarsely dentate, smooth above, hairy in the axils of the veins beneath, short-petioled; cymes long-peduncled, 7 -rayed, $2-3$ in. wide; sterile flowers none; calyx smooth; fruit globose, dark blue, stone compressed, grooved on one side. March-May. In rich, damp soil.

3. V. nudum L. Withe-Rod. A shrub 8-12 ft. high; leaves ovate to lanceolate, entire or slightly toothed, acute at both ends, thick, smooth above, the veins prominent beneath; petiole short; cymes short-peduncled, o-rayed; sterile flowers none; fruit ovoid, blue. April-May. Common in swamps.

4. V. scabrellum T. \& G. Rough Arrow-wood. A shrub 8-12 ft. high; leaves ovate to nearly orbicular, acute at the apex, cordate, rounded or cuneate at the base, coarsely serrate, thick, stellatetomentose beneath, short-petioled; cymes peduncled, 7-rayed; calyx and corolla hairy; fruit globose, dark blue. May-June. Swamps and river banks.

5. V. prunifolium L. Black Haw. A small tree $15-20 \mathrm{ft}$. high; leaves oval to ovate, acute or obtuse at each end, finely and sharply serrate, smooth and shining above, often slightly pubescent beneath; petioles dilated and rusty-pubescent; cymes sessile, large, 4-5-rayed; sterile flowers none; drupe oval, bluish-black, edible. April-May. In rich, moist woods. 


\section{SYMPHORICARPOS.}

Shrubs ; leaves short-petioled, deciduous ; flowers in axillary clusters; calyx tube globose, 4-5-toothed; corolla campanulate, 4-5-lobed, sometimes gibbous at the base, smooth or hairy within; stamens 4-5; ovary 4-celled, 2 of the cells with a single fertile ovule in each, the other cells with several abortive ovules; style slender, stigma capitate or 2-lobed; fruit a 4-celled, 2-seeded berry.

S. Symphoricarpos (L.) MacM. Coral Berry. A slender, branching shrub 2-4 ft. high; twigs purple; leaves oval to ovate, entire or nearly so, smooth above, pubescent beneath; flowers in small, axillary clusters; corolla pinkish, nearly smooth within; style bearded; fruit red, globose, persistent through the winter. JuneSeptember. River banks, on dry soil.

\section{LONICERA.}

Shrubs or woody vines; leaves simple, usually entire, often connate; calyx tube ovoid, 5-toothed; corolla tubular to campanulate, often gibbous at the base or bilabiate; stamens 5 ; ovary 2-3-celled, ovules several in each cell, style slender, stigma capitate; fruit a 1-3-celled, 1-few-seeded berry.

1. L. Flava Sims. Yellow Honeysuckle. Stem somewhat twining; leaves oval to obovate, obtuse, entire, green above, glaucous beneath, the lower short-petioled, the upper sessile or connate; flowers in crowded, terminal whorls, bright yellow, fragrant; corolla tube slender, 1-1 $\frac{1}{2}$ in. long, bilabiate, 4-lobed, pubescent within; stamens and style exserted. April-July. On river banks and hillsides; often cultivated.

2. L. Sempervirens L. Coral Honeysuckle. Stem twining high ; leaves evergreen, oval to oblong, obtuse, entire, smooth above, pale and often pubescent beneath, the lower petioled, the upper pair nearly semi-orbicular and connate; flowering spikes terminal, bearing several whorls; corolla about 2 in. long, slender, smooth, the limb short, nearly equally 5-lobed, scarlet without, bright yellow within; stamens slightly exserted; fruit red. April-September. On low ground; often cultivated.

3. L. Ja Ponica Thunb. Japan Honeysuckle. Stem twining high; young branches pubescent; leaves ovate to oblong, entire, smooth above, pale and pubescent beneath, all short-petioled; pedun- 
cles axillary, 2-bracted, 2-flowered; flowers white or pink, fading to yellow, bilabiate, the lips nearly as long as the pubescent tube; stamens and style exserted; truit black. May-August. Introduced from Japan; common in cultivation.

\section{DIERVILLA.}

Shrubs; leaves serrate, short-petioled; flowers in axillary cymes; calyx tube oblong, 5-toothed, teeth linear; corolla funnel-form, gibbous at the base, nearly equally 5-lobed; stamens 5 ; ovary 2-celled, many-ovuled, style slender, stigma capitate; fruit a 2 -celled, 2 -valved, many-seeded capsule.

D. JAPONica Thunb. Wergela. A stout, branching shrub 3-6 ft. high ; leaves broadly oval, acute at the apex, rounded at the base, coarsely serrate, rough above, pubescent beneath, short-petioled; flowers spreading, funnel-form, rose-color, $1-1 \frac{1}{2}$ in. long; calyx lobes deciduous; corolla pubescent without, the lobes spreading; capsule oblong or fusiform; seeds reticulate-winged. April-May. Introduced from Japan; common in cultivation.

\section{VALERIANACEÆ. VALERIAN FAMILY.}

Annual or perennial herbs; leaves opposite, exstipulate; flowers perfect or polygamo-diøecious, in panicled or corymbose cymes; calyx tube adherent to the ovary, the limb toothed, lobed, pappus-like or wanting; corolla tubular to funnel-form, 5-lobed, gibbous at the base; stamens mostly 3 , inserted in the tube of the corolla; ovary 3-celled, 2 of the cells abortive, the other containing a single ovule; style filiform, stigma entire or lobed; fruit a nerved achene.

\section{VALERIANELLA.}

Annual herbs; stem forking regularly; leaves opposite, entire or dentate; flowers in crowded, terminal, bracted cymes; calyx limb toothed or wanting; corolla white or purplish, funnel-form, 5-lobed; stamens 3 ; style 3-lobed; fruit 3-celled, 1-seeded.

1. V. Locusta (L.) Bettke. Lamb Letruce. Stem erect, smooth, or pubescent at the nodes, many times forked, 9-12 in. 
high; basal leaves tufted, spatulate to obovate, entire, the upper lanceolate, dentate, sessile; cymes short-peduncled, bracts linear; flowers pale blue; fruit compressed, oblique. April-June. On rich soil in waste places.

2. V. Radiata (L.) Dufr. Corn Salad. Stem erect, smooth above, pubescent below, 2-4 times forked, 8-12 in. high; lower leaves spatulate, entire, the upper lanceolate, clasping at the base, dentate; cymes compact; bracts lanceolate; flowers white; fruit ovoid, downy, furrowed. February-April. On damp soil.

\section{CUCURBITACE E. GOURD FAMILY.}

Annual or perennial herbs; stems succulent, tendril-bearing, climbing or trailing; leaves alternate, simple, petioled, palmately veined or lobed, exstipulate; flowers axillary, solitary or racemed, monœcious or diœcious; calyx tube adnate to the ovary, 5-lobed; corolla usually gamopetalous, inserted on the calyx; stamens mostly 3,2 of them with the anthers 2-celled, the other with the anther 1-celled; filaments short, often united; ovary 1-3-celled, style entire or lobed; fruit usually fleshy, 1-3-celled, seeds flat.

\section{CUCURBITA.}

Annual or perennial herbs; stem trailing, 2-20 ft. long; leaves angular-lobed; tendrils branching; flowers monœcious, solitary or in small clusters; calyx 5 -toothed, the limb deciduous; corolla bell-shaped, 5-lobed; staminate flowers with 3 stamens and no pistil, pistillate flowers with 1 pistil and 3 abortive stamens; style short, stigmas 3-5, each 2-lobed; fruit 1-celled with numerous seeds on the 3 parietal placentæ.

1. C. melopepo L. Summer Squash. Stem rough-hairy, angled, 2-5 ft. long; leaves broadly cordate, angularly 3-5-lobed, rough; flowers yellow, short-peduncled; fruit orbicular, longitudinally compressed, the margin smooth, wavy or tubercular. MayJuly. Common in cultivation.

2. C. verrucosa L. Crookneck Squash. Stem rough-hairy, angled and striate, 5-10 ft. long; leaves cordate, deeply 5-lobed, very rough, long-petioled ; flowers light yellow, long-peduncled; fruit clavate, the base often slender and curved, smooth or tuberculate, very variable. June-August. Common in cultivation. 


\section{MELOTHRIA.}

Perennial; stem slender; tendrils rarely branched; leaves entire or angular-lobed; flowers polygamous or diøecious; staminate flowers clustered, calyx and corolla campanulate, 5 -lobed, pistil minute or wanting; pistillate flowers solitary, calyx contracted above the ovary, corolla campanulate, 5parted; ovary 3-celled, many-ovuled, style short, stigmas 3 ; fruit smooth, berry-like, many-seeded.

M. pendula L. Creeping Cuccuber. Stem very slender, smooth, branched, climbing, 3-6 ft. long; leaves cordate, rough, 3-5-lobed, the lobes toothed; flowers yellow, the staminate in fewflowered racemes, the pistillate solitary, on long and slender drooping peduncles; fruit oval, about $\frac{1}{2}$ in. long, greenish-black. MayAugust. In thickets on light soil.

\section{SICYOS.}

Annual; stem slender; tendrils branched; leaves angled; flowers monœcious; calyx tube campanulate, with 5 minute teeth; corolla rotate, the limb deeply 5-parted; staminate flowers in racemes, pistillate flowers in eapitate clusters; ovary 1-celled, 1-ovuled, style short, slender, stigmas 3 ; fruit membranaceous, bristly, 1-seeded.

S. angulatus L. Star Cucumber. Stem slender, clammypubescent, somewhat angled, climbing 10-20 ft.; tendrils mostly 3 -forked; leaves thin, cordate to orbicular, angled and denticulate, rough on both sides; flowers greenish-white; fruit long-peduncled, yellowish, indehiscent. June-August. River banks and damp places.

[Among the cultivated plants belonging to this family are the watermelon and citron (Citrullus vulgaris), the cucumber (Cucuinis sativus), the muskmelon (Cucumis melo), and the Gourd (Lagenaria vulgare).]

\section{CAMPANULACE $Æ$. BELL-FLOWER FAMILY.}

Annual, biennial or perennial herbs, juice acrid or milky; leaves alternate, entire, dentate or lobed, exstipulate; flowers perfect, regular or irregular; calyx tube adherent to the 
ovary, the limb 3-5-lobed, usually persistent; corolla inserted at the top of the calyx tube, 5 -lobed, often bilabiate with the tube split to the base on one side; stamens 5 , alternate with the lobes of the corolla, filaments and anthers distinct or united; ovary 1-5-celled, style single, smooth or bearded; fruit a capsule.

\section{CAMPANULA.}

Annual, biennial or perennial herbs; flowers solitary, racemed or spiked, regular, blue or white; calyx 5-lobed or parted; corolla rotate to bell-shaped, 5-lobed; stamens 5, free from the corolla, distinct, filaments dilated at the base; ovary 3-5-celled, many-ovuled, style 3-parted; capsule short, bearing the persistent calyx lobes at its apex, many-seeded, dehiscent on the sides.

C. Americana L. Tall Bell-flower. Annual or biennial; stem erect, slender, smooth or pubescent, simple or with a few ascending branches above, 2-5 ft. high ; leaves ovate to lanceolate, acuminate at the apex, tapering below into a short petiole, serrate, thin; flowers in an elongated, leafy spike, single or 2-3 together; calyx lobes slender, spreading; corolla blue, 1 in. wide, rotate ; style curved, long-exserted; capsule strongly ribbed, longer than the calyx lobes. June-September. In moist, open woods.

\section{LEGOUZIA.}

Annual; stems slender, angled; leaves entire or toothed; flowers axillary, regular, solitary or in small clusters, sessile, bracted; calyx tube slender, 3-5-parted; corolla rotate, 5-lobed; stamens with the filaments flattened and shorter than the anthers; ovary 3-celled, many-ovuled, stigmas 3 ; fruit a prismatic, 3-celled, many-seeded capsule.

1. L. biflora (R. \& P.) Britt. Specularia. Stem erect, simple or branched from the base, angles roughened, 10-20 in. high; leaves ovate to lanceolate, acute at the apex, sessile, crenate or entire, the upper bract-like; flowers solitary or in pairs ; corolla blue, often wanting; capsule cylindrical, smaller above. March-July. In waste places. 
2. I. Perfoliata (L.) Britt. Venus's Looking-glass. Stem simple or branched, slightly pubescent, smooth or rough on the angles, 1-2 ft. high; leaves very numerous, round-cordate, clasping at the base, crenate or sometimes entire; flowers solitary or 2-3 together; calyx teeth $3-5$; corolla blue, sometimes wanting; capsule oblong, ribbed. May-September. Common in fields and waste places.

\section{LOBELIA.}

Annual, biennial or perennial, with acrid, poisonous juice; stems erect; leaves alternate, sometimes nearly all basal, mostly serrate with glandular-pointed teeth ; flowers in terminal, leafy-bracted spikes or racemes, red, white or blue, irregular; calyx 5-lobed; tube of the corolla straight or curved, split to the base on one side, the limb bilabiate, the upper lip smaller, with 2 erect or reflexed lobes, the lower lip spreading, 3-lobed; stamens 5, free from the corolla, monadelphous, some or all of the anthers with a tuft of hair at the apex, united around the style; ovary 2-celled, manyovuled, style single, slender, stigma 2-lobed, fringed; fruit a 2-celled, many-seeded capsule.

1. L. Paludosa Nutt. Swamp Lobelia. Perennial; stem smooth and glabrous, simple or with a few erect branches, nearly leafless, 2-4 ft. high; leaves mostly basal, fleshy, spatulate to linear, entire or denticulate, the lower narrowed into a petiole, the upper sessile; flowers small, pale blue or white, in loose racemes, bracts small; calyx lobes slender, not appendaged; lower lip of the corolla pubescent. May-August. Swamps in pine barrens.

2. L. Cardinalis L. Cardinal Flower. Perennial; stem stout, smooth or slightly pubescent, simple, 2-4 ft. high; leaves numerous, oblong to lanceolate, acuminate at the apex, denticulate, thin, smooth or slightly pubescent, the lower petioled, the upper sessile; flowers in a bracted raceme, bright scarlet, 1-1 $\frac{1}{2}$ in. long, very showy ; bracts leaf-like; calyx smooth or pubescent, not appendaged, the lobes linear; stamens and style exserted. June-September. On wet soil.

3. L. syphilitica L. Blue Lobelia. Perennial; stem stout, pubescent, simple, 1-3 ft. high; leaves very numerous, lanceolate to oval, acute at each end, thin, smooth, coarsely serrate, sessile or the lower petioled; flowers bright blue, in a dense, leafy raceme; calyx hairy, the lobes lanceolate, denticulate, half the length of the corolla, with deflexed, auricled appendages in the sinuses; corolla about 1 in. long, glabrous. June-October. On wet soil. 
4. L. spicata Lam. Spiked Lobelia. Biennial or perennial; stem pubescent, simple, 1-3 ft. high; lower leaves oval to obovate, obtuse at the apex, denticulate, narrowed below to the short petiole, upper leaves smaller, lanceolate, sessile; raceme long and dense; pedicels short; bracts linear; flowers small, pale blue; calyx tube smooth, shorter than the lobes, without appendages; corolla $\frac{1}{3}-\frac{1}{2}$ in. long. June-August. On dry, sandy soil.

\section{CICHORIACEÆ. CHICORY FAMILY.}

Annual or perennial herbs; juice milky, usually acrid and bitter; leaves alternate or basal; flowers in a close head which is surrounded by an involucre consisting of 1 or more rows of bracts; the receptacle naked or with chaffy scales, nearly smooth or pitted, flat or convex; flowers perfect; the calyx tube adnate to the ovary, the limb sometimes wanting, but usually prolonged above into a pappus of scales, bristles, or fine hairs which are often plumose; corolla tubular below, prolonged above into a strap-shaped or ligulate ray which is usually 5-toothed at the apex; stamens 5, inserted in the tube of the corolla, the anthers united into a ring about the slender, 2-lobed style; ovary 1-celled; fruit an achene.

\section{SERINIA.}

Annual; stem branching, glaucous; leaves lanceolate to linear, entire or lobed, petioled or sessile; flowers yellow, in long-peduncled heads; the involucre spreading in flower, connivent in fruit, usually of 8 equal bracts about as long as the corollas; receptacle naked; achenia ovoid-oblong, ribbed and striate, pappus none.

S. oppositifolia (Raf.) Kuntze. Serinia. Stem very glaucous, succulent, branched below, 4-12 in. high ; lower leaves lanceolate, entire or pinnatifid, long-petioled, the upper narrower and usually entire, clasping, the two highest often nearly opposite; peduncles long and slender, often glandular-pubescent near the apex; heads 10-20-flowered; rays truncate, 5-toothed at the apex. March-May. In dry, open fields. 


\section{ADOPOGON.}

Annual or perennial; leaves mostly basal, entire, toothed or pinnatifid; heads long-peduncled, 15-many-flowered; involucre of $6-15$ nearly equal bracts in 1 or 2 rows; receptacle naked; flowers yellow or orange; rays truncate, 5 -toothed at the apex ; achenes short, oblong or top-shaped, 4-5-angled and ribbed; pappus double, the outer row of short, chaffy scales, the inner of slender bristles.

1. A. Virginicum (L.) Kuntze. Goat's-beard. Perennial; stem erect, smooth and glaucous, branched above, 1-2 ft. high ; leaves oval to oblong, the lower long-petioled and toothed, the upper sessile and often entire; stem umbellately branched, bearing 2-5 longpeduncled heads; involucral bracts $9-15$; flowers orange; achenes oblong, 15-20-ribbed ; scales of the pappus oblong, numerous, bristles slender, numerous. April-July. Common on sandy soil.

2. A. Dandelion (L.) Kuntze. Goat's-Beard. Perennial; acaulescent; roots often bearing small tubers; leaves spatulateoblong to linear, entire or toothed; scapes often several, leafless, glaucous, 6-15 in. high; heads single; involucral bracts 12-15; flowers yellow; achenes somewhat top-shaped, obscurely 4-angled; pappus of numerous short scales and slender bristles. March-May. Common on damp soil.

3. A. Carolinianum (Walt.) Britt. Carolina Goat's-Beard. Annual; nearly acaulescent; leaves spatulate-oblong, mostly lyrate or pinnatifid, glaucous or slightly pubescent; scapes several, glaucous, 3-12 in. high; involucral bracts $6-15$, in 2 irregular rows, reflexed at maturity; flowers yellow; achenes top-shaped, 5-angled; pappus of 5 short and rounded scales and 5-10 rough bristles. February-May. On dry, sandy soil.

\section{TARAXACUM.}

Perennial ; acaulescent; leaves all basal, entire or pinnatifid ; scapes often several, tubular; heads large, solitary ; involucre double, the outer several irregular series of unequal, spreading bracts, the inner a single row of equal, erect bracts which are somewhat united at the base, all reflexed at maturity; receptacle naked; flowers yellow; rays truncate, 5 -toothed at the apex ; achenes oblong, with 5-10 roughened nerves, tapering into a slender beak above; pappus of numerous white hairs. 
T. Taraxacum (L.) Karst. Dandelion. From a large, deep root; leaves spatulate to elliptical, irregularly toothed or pinnatifid, narrowed into a margined petiole; scapes erect, 4-12 in. high; heads $1 \frac{1}{2}-2$ in. wide; involucral bracts lanceolate to linear; flowers bright yellow, very numerous; achenes quite rough above, $\frac{1}{4}-\frac{1}{3}$ the length of the filiform beak which is developed as the achenes mature; pappus a globose tuft of soft, white hairs. February-July. In lawns and along roadsides; introduced.

\section{SONCHUS.}

Annual or perennial; leaves mostly toothed or pinnatifid, prickly margined; heads in corymbs or panicles; bracts in several series, the outer shorter; receptacle naked; flowers yellow ; rays truncate, 5-toothed at the apex; achenes oval to oblong, compressed, ribbed, truncate at the apex; pappus of numerous soft, white hairs.

1. S. oleraceus L. Sow Thistle. Annual; stem erect, branched, smooth, 2-6 ft. high; leaves spiny toothed, the lower long-petioled, very irregularly cut or pinnatifid, the upper clasping by an auricled base; involucre downy when young; achenes striate and transversely wrinkled. May-August. In waste places on very rich soil.

2. S. Asper (L.) All. Spiny Sow Thistle. Annual; stem erect, smooth, branched but little, 2-6 ft. high; leaves undivided, spatulate to oblanceolate, fringed with spiny teeth, the lower narrowed into a petiole, the upper clasping by an auricled base, the auricles rounded; heads numerous; involucre glabrous; achenes flattened, margined, 3-nerved on each side, smooth. May-September. In waste places.

\section{LACTUCA.}

Annual, biennial or perennial; stems leafy; leaves entire to pinnatifid; heads panicled; involucre cylindrical, bracts unequal, imbricated in 2 or more rows, the outer shorter; receptacle naked; flowers blue, yellow or white; rays truncate, 5 -toothed at the apex; achenes compressed, ribbed, the apex contracted into a slender beak which is enlarged into a disk bearing the soft, hairy, white or tawny pappus.

1. L. Canadensis L. Wild Lettuce. Biennial; stem erect, smooth, hollow, branched above, 3-10 ft. high; leaves lanceolate to 
spatulate, pale beneath, the lower petioled and pinnatifid, the upper sessile, clasping, and nearly entire; heads numerous, about 20-flowered; flowers yellow; achenes oval, flat, 1-ribbed on each side, minutely roughened, about as long as the beak; pappus white. June-October. In waste places.

2. L. villosa Jacq. Blue Lettuce. Stem very leafy, smooth, paniculately branched above, 3-6 ft. high; leaves ovate to lanceolate, acuminate, often hairy beneath, the lower on winged petioles and often sinuate-lobed, the upper sessile; heads racemed, on divergent-and bracted peduncles; flowers blue; achenes slightly compressed, beak very short; pappus white. June-September. In waste places.

\section{SITILIAS.}

Annual or biennial; stem erect, leafy below, nearly naked above, smooth; leaves oblong, toothed or pinnatifid; heads large, long-peduncled; involucre cylindrical or spreading, the inner row of bracts erect, united at the base, the outer rows shorter and spreading; receptacle naked; flowers yellow ; rays truncate, 5-toothed at the apex; achenes oblong, 5-ribbed, narrowed above into a long and slender beak; pappus soft, tawny, with a short, villous ring at the base.

S. Caroliniana (Walt.) Raf. False Daxdelion. Annual or biennial; stem glabrous, furrowed, branched above, 2-3 ft. high; lower leaves lanceolate to oblong, entire, toothed or pinnatifid, narrowed into a margined petiole, the upper sessile, bract-like, entire; heads few, long-peduncled, peduncles and involucre sometimes puberulent; inner bracts calloused at the apex, the outer subulate and spreading; achenes much shorter than the filiform beak. AprilJuly. Common in fields.

\section{COMPOSITAE. THISTLE FAMILY.}

Herbs or shrubs, with watery or resinous juice; leaves opposite, alternate or basal, entire, toothed, or divided, exstipulate; flowers in heads surrounded by an involucre of bracts in 1 or more rows; the receptacle naked or chaffy, smooth or pitted, concave, flat or convex; flowers perfect or variously imperfect; calyx tube adnate to the ovary, the limb prolonged above into a pappus of scales, bristles or 
hairs, or rarely wanting; corolla tubular, 5-toothed or rarely bilabiate, the corollas of the marginal flowers often prolonged into a strap-shaped or ligulate ray; when both tubular and ray flowers are present the head is said to be radiate, and when all the flowers are tubular it is said to be discoid ; stamens usually 5 , united by their anthers into a ring about the slender, 2-cleft style; fruit an achene.

The largest family of flowering plants, and the one in which the flowers are most highly specialized. Fully ten thousand species are known, though comparatively few are of great economic importance. Most of the species bloom late in the season.

Heads discoid.

Receptacle naked.

Pappus of chaffy bristles

Pappus of capillary bristles

Pappus of plumose bristles

Pappus of bearded bristles

Receptacle chaffy

Receptacle bristly

Heads radiate.

Rays yellow.

Receptacle naked.

Pappus capillary, heads racemed .

Pappus capillary, heads corymbed

Pappus of chaffy scales

I. Elephantopus.

II. Eupatorium.

III. Lacinaria.

IV. Trilisa.

XII. Bidens.

XVI. Carduus.

Receptacle chaffy.

Leaves alternate, rays fertile

Leaves alternate, rays neutral
V. Solidago.

$\mathrm{XV}$. Senecio.

XIII. Helenium.

Leaves opposite.

Pappus of 2 chaffy scales or wanting.

Involucre in several rows

X. Helianthus.

Involucre in 2 rows

XI. Coreopsis.

Pappus of 2-4 barbed awns

XII. Bidens. 
Rays white or purplish.

Receptacle naked.

Disk flowers tubular.

Bracts imbricated in several rows .

Bracts only slightly imbricated .

Disk flowers bilabiate

Receptacle chaffy. . . . .

\author{
VI. Aster. \\ VII. Erigeron. \\ XVII. Thyrsanthema. \\ XIV. Achillea.
}

\section{ELEPHANTOPUS.}

Perennial herbs; stem scape-like, corymbosely branched above; leaves mostly basal and nearly entire; heads small, in dense, bracted clusters, discoid, 3-5-flowered; involucre oblong, its bracts about 8 , in 2 series, the outer shorter; receptacle naked; corollas all alike, deeply 5-lobed, deeply cleft on one side, purple; achenes oblong, ribbed, hairy; pappus of rigid, awn-like scales or bristles which are dilated at the base.

1. E. Carolinianus Willd. Carolina Elephant's Foot. Stem erect, hairy, leafy, 1-2 ft. high; leaves oval to obovate, obtuse at the apex, narrowed below into a winged petiole, serrate or dentate, the upper often sessile; bracts 3-5, ovate, longer than the heads; involucral bracts slightly hairy; achenes hairy, 10-ribbed. June-September. In damp, shady places.

2. E. tomentosus L. Woolly Elephant's Foot. Stem erect, rough-hairy, nearly leafless, 1-2 ft. high; leaves mostly basal, obovate-oblong, on a margined petiole, crenate, soft-pubescent beneath, stem leaves 1 or 2, small, sessile; bracts ovate to cordate, shorter than the heads, involucral bracts very hairy; achenes nearly smooth, 10-ribbed. June-August. In damp soil.

\section{EUPATORIUM.}

Perennial herbs; stems leafy; leaves opposite, verticillate or sometimes alternate, often resinous-dotted; heads discoid, 3 -many-flowered, in cymes or panicles; involucre cylindrical or spreading, its bracts imbricated in 2 or more series ; receptacle naked; flowers white, blue or purple; corolla slender; achenes 5-angled, truncate, smooth; pappus a single row of rough bristles. 
1. E. purpureum L. Purple Boneset. Stem erect, smooth or slightly pubescent, often striate, branched above, 3-10 ft. high ; leaves $3-6$ in a whorl, lanceolate to ovate, petioled, coarsely serrate, roughened; heads in large, compound corymbs, 5-10-flowered; bracts purplish, obtuse, imbricated in several rows, the outer shorter; flowers pink or purple. July-September. In moist woods.

2. E. album L. White Thorovghwort. Stem erect, roughpubescent or hairy, branched above, 1-3 ft. high; leaves opposite, lanceolate to oblong, obtuse or acute at the apex, narrowed at the base, nearly or quite sessile, serrate, strongly veined; heads numerous, in dense corymbs, 5-flowered; involucre slender, its bracts in 2-3 series, linear to lanceolate, with white and scarious edges, the tips mucronate; flowers white. July-September. Common on dry, sandy soil.

3. E. rotundifolium L. Round-leaved Thoroughwort. Stem erect, rough-pubescent, simple or branched above, 2-3 ft. high; leaves opposite, broadly ovate to roundish, truncate and sessile at the base, obtusely serrate, 3-ribbed, rugose ; corymbs large, heads 5 -flowered; involucre spreading, its bracts in 2-3 series, lanceolate, densely pubescent; flowers white. June-September. On dry soil.

4. E. perfoliatum L. Boneset. Stem erect, stout, pubescent or hairy, branched above, 2-4 ft. high; leaves opposite, lanceolate, connate-perfoliate, crenate-serrate, rugose, with a prominent vein near the margin; corymb large and spreading; heads about 10 -flowered; involucre spreading, the bracts linear-lanceolate, acute; flowers white. July-September. On low ground. A popular domestic remedy.

כ. E. coelestinum L. Mist Flower. Stem erect, slender, smooth or pubescent, widely branched, 2-3 ft. high ; leaves opposite, ovate to deltoid or sometimes cordate, acuminate at the apex, petioled, coarsely dentate; corymbs spreading, heads many-flowered; involucre spreading, bracts nearly equal, linear-lanceolate; flowers blue or purple. June-September. On rich soil.

\section{LACINARIA.}

Perennial from tuberous roots; stems usually simple; leaves alternate, narrow, entire; heads discoid, spiked or racemed, few- or many-flowered; involucre oblong or bellshaped, its bracts imbricated in several rows, the outer shorter; receptacle naked; corollas slender, purple to white; achenes slender, narrowed to the base, 10-ribbed; pappus of numerous plumose bristles.

1. L. Squarrosa (L.) Hill. Blazing-star. Stem erect, stout, simple, smooth or pubescent, 1-2 ft. high; leaves numerous, linear, 
rigid, smooth or hairy, 3-5-ribbed; heads few, about $1 \mathrm{in.}$ long, in a leafy-bracted spike, many-flowered; bracts in several rows, with rigid, acuminate, spreading tips; lobes of the corolla hairy; pappus very plumose. June-September. On dry soil.

2. L. Elegans (Walt.) Kuntze. Showy Blazing-star. Stem erect, tomentose, simple, $2-3 \mathrm{ft}$. high ; leaves very numerous, linear, punctate, the upper small and bract-like; heads very numerous, showy, 4-5-flowered, in a long and dense spike or raceme; bracts numerous, in 2--3 series, the tips of the inner ones spreading and petal-like, the outer ones loose; pappus very plumose. July-August. On dry pine barrens.

3. L. scariosa (L.) Hill. Button Snakeroot. Stem stout, simple, pubescent, 3-6 ft. high ; leaves pubescent and punctate, the lower spatulate to oblanceolate, the upper linear and acute; heads large, often $1 \mathrm{in}$. wide, many-flowered, sessile or short-peduncled, in long spikes; flowers bluish purple; involucral bracts in several series, obtuse, the margins colored; pappus short-plumose. JulySeptember. On dry soil.

4. L. Spicata (L.) Kuntze. Spiked Button Snakeroot. Stem erect, smooth, simple, very leafy, 3-6 ft. high; lower leaves linear, obtuse, erect, $1 \mathrm{ft}$. or more in length, 3-5-ribbed, the upper smaller and bract-like; heads in a long and dense spike, cylindrical, 8-12flowered; flowers blue-purple to white; involucral bracts in 4-6 rows, smooth, purple, obtuse and scarious-margined at the apex; pappus short-plumose. July-September. On moist soil.

\section{TRILISA.}

Perennial from a fibrous root; leaves alternate; heads in corymbs or panicles, few-flowered, discoid; bracts in 2-3 rows, the outer shorter; receptacle naked; corolla 5-lobed; achenes oblong, 10-ribbed; pappus of barbed bristles.

T. odoratissima (Walt.) Cass. Deer-tongue. Vanilla Plant. Stem erect, stout, smooth and glaucous, often purple, branched above, 2-4 ft. high; lower leaves oblong to spatulate, 3-5-ribbed, thick, smooth, entire, petioled, the upper smaller and sessile; heads in corymbs, 7-9-flowered, flowers purple; bracts oblong, obtuse; achenes pubescent; pappus minutely bearded. July-September. In flat pine barrens. The withering plants strongly vanilla-scented.

\section{SOLIDAGO.}

Perennial herbs, or rarely shrubby; leaves alternate, entire or toothed; heads small, radiate; involucral bracts imbri- 
cated in several rows; receptacle pitted; flowers yellow, ray flowers 1-16, in a single row, pistillate, disk flowers mostly perfect; achenes terete, ribbed; pappus of numerous, slender, scabrous bristles. A large genus, nearly all flowering late in the season.

1. S. Cesia L. Blue-stemmed Golden-Rod. Stem erect, slender, smooth and glaucous, usually blue or purple, simple or branched, 2-3 ft. high ; leaves lanceolate, acuminate, sessile, sharply serrate, smooth; heads in axillary racemes shorter than the leaves, about 10-flowered; rays 3-4; achenes pubescent. August-September. In woods and thickets.

2. S. Canadensis L. Canadian Golden-Rod. Stem stout, erect, rough-pubescent, branched above, 3-8 ft. high; leaves lanceolate, serrate, 3-nerved, the lower petioled, the upper sessile; heads very numerous, on one side of the curved branches of a large panicle; involucral bracts linear; ray flowers 9-15; achenes pubescent. July-November. Margins of fields, on dry ground.

3. S. nemoralis Ait. Field Golden-rod. Stem slender, erect, gray with dense pubescence, simple, 1-2 ft. high; leaves obscurely 3 -nerved, the lower lanceolate to spatulate, serrate, petioled, the upper lanceolate, mostly entire, sessile; heads many, the racemes in a dense panicle with curved branches, 10-12-flowered; bracts linearoblong; ray flowers 6-7; achenes pubescent. June-August. Common in open fields.

\section{ASTER.}

Perennial or rarely annual; leaves alternate; heads usually corymbed or panicled, many-flowered, radiate; bracts imbricated in several rows, the outer shorter, the tips spreading; receptacle naked, pitted; ray flowers pistillate, in a single row, disk flowers perfect, tubular; achenes compressed, nerved; pappus a single or double row of slender, scabrous bristles.

1. A. Azureus Lindl. Blue Aster. Stem erect, slender, rigid, rough, branched above, 2-3 ft. high; lower leaves lanceolate to cordate, acute or obtuse at the apex, truncate or cordate at the base, entire, long-petioled, the upper lanceolate to linear, sessile, those of the branches subulate; heads numerous; involucre turbinate, the bracts smooth, appressed; ray flowers 10-20, bright blue; pappus tawny. July-September. On dry ground.

2. A. undulatus L. Wavy-leaved Aster. Stem erect, rigid, rough-pubescent, widely branched above, 2-3 ft. high; leaves lanceolate to ovate, rough, entire, undulate or serrate, the lower cordate, 
on long and margined petioles which are clasping at the base, the upper sessile or clasping, those of the branches very small; heads numerous, racemose, $\frac{3}{4}$ in. wide; involucral bracts linear ; ray flowers 8-15, pale blue; pappus white. July-October. Common on dry soil, and very variable.

3. A. Patens Ait. Purple Aster. Stem erect, rough-pubescent, widely branched above, 2-4 ft. high; leaves ovate-oblong to lanceolate, thin, acute or obtuse, clasping by an auricled base, the upper small and bract-like, with ciliate margins; heads numerous, 1 in. wide, on the ends of the paniculate branches; bracts linear; ray flowers 20-30, blue or violet; pappus tawny; achenes pubescent. July-October. Common on dry ground.

4. A. concolor L. Silvery Aster. Root often tuberous; stem erect, slender, smooth or pubescent above, simple, 2-3 ft. high; leaves lanceolate to oblong, entire, sessile, silky on both sides when young; heads numerous, terminating the peduncle-like branches, the bracts lanceolate, appressed, with spreading tips; ray flowers 10-15, lilac; achenes silky; pappus tawny. July-October. On dry, sandy ground.

5. A. Dumosus L. Bushy Aster. Stem erect, slender, smooth, much branched, 2-3 ft. high; lower leaves spatulate, dentate, the upper nearly linear and entire, those of the branches subulate; heads very numerous, small, campanulate; bracts linear, with spreading tips ; ray flowers 15-30, purple or white; achenes pubescent, pappus white. July-October. Common and quite rariable.

\section{ERIGERON.}

Annual or perennial; leaves alternate; heads solitary, panicled or corymbed, hemispherical, many-flowered, radiate ; bracts nearly equal, in 1 or 2 rows; receptacle naked; ray flowers numerous, pistillate, white to purple, disk flowers tubular, perfect; achenes compressed, 2-nerved; pappus a row of slender, scabrous bristles, often with an outer row of chaffy scales or short bristles.

1. E. Philadelphicus L. Fleabane. Perennial, often producing runners; stem erect, slender, hairy, branched above, 2-4 ft. high; leaves thin, entire or coarsely toothed, sessile, the lower spatulate-oblong, the upper lanceolate, clasping; heads in corymbs or panicles, peduncled; bracts linear; ray flowers numerous, shorter than the bracts, narrow, purplish; achenes slightly pubescent; pappus a single row of bristles. April-July. Common on low ground.

2. E. ramosus (Walt.) B. S. P. Daisy Fleabane. Annual; 
stem erect, slender, rough-pubescent, paniculately branched above, 2-3 ft. high; leaves entire or slightly serrate, pubescent, the lower oval to oblong, long-petioled, the upper lanceolate to linear, sessile; heads small, in corymbose panicles; bracts smooth; ray flowers numerous, white or purplish; pappus double, the outer row of short, chaffy scales, the inner of rough hairs. May-September. Common in old fields.

3. E. vernus (L.) T. \& G. Early Fleabane. Perennial, from a thick rootstock; stem erect, slender, smooth, scape-like, 1-2 ft. high; leaves mostly basal, spatulate to obovate, thick, entire or slightly toothed, with a margined petiole, upper leaves small and bract-like; heads in small, peduncled corymbs; bracts linear; ray flowers 20-30, white or pink; pappus single. March-May. Common on wet ground.

\section{SILPHIUM.}

Perennial herbs with resinous juice; stems erect, leafy; leaves alternate, opposite or whorled; heads radiate, large, in corymbs or panicles; involucral bracts leafy, imbricated in several rows, the inner small and chaffy; receptacle with linear, acute chaff; ray flowers numerous, yellow, pistillate and fertile, disk flowers numerous, perfect but sterile; style undivided; achenes in 3-4 rows, compressed, orbicular to obovate, winged on the edges, emarginate at the apex; pappus none, or coalesced with the 2 teeth of the achene.

1. S. laciniatum L. Compass Plant. Stem stout, striate, rough-hispid with white hairs, rery resinous, few-leaved, simple, 4-8 ft. high; leaves mostly basal, petioled, oval in outline, deeply pinnately parted, rough-hispid, mostly erect and facing to the east or west, stem leaves alternate, small, nearly entire; heads spiked or racemed ; bracts large, ovate, the tips spreading; ray flowers 20 30, 2-3 in. wide; achenes round-oborate, emarginate. June-September. On prairies and open grounds.

2. S. terebinthinaceum Jacq. Prairie Dock. Stem smooth, branched above, nearly leafless, $3-8 \mathrm{ft}$. high; leaves nearly all basal, cordate-ovate, acute at the apex, coarsely toothed, rough, longpetioled, mostly facing to the east or west; heads loosely panicled, 2-3 in. wide; bracts oval, obtuse, smooth; ray flowers $12-20$; achenes obovate, 2-toothed at the apex. June-September. In open woods and fields. 


\section{RUDBECKIA.}

Perennial or biennial ; leaves alternate, entire or lobed ; heads radiate, long-peduncled, many-flowered; bracts imbricated in 2-3 series, spreading; receptacle convex or long-conical, with concave, chaffy scales; ray flowers yellow, neutral, disk flowers purple to brown, perfect; achenes smooth, 4-angled, truncate; pappus a few short teeth or wanting.

1. R. triloba L. Thin-leaved Cone-flower. Biennial; stem erect, rough-hairy, branched, 2-5 ft. high; leaves thin, rough on both sides, the lower long-petioled, simple or with 2 lateral lobes, middle leaves short-petioled, deeply 3-lobed or parted, the lobes serrate, upper leaves mostly simple, sessile, entire; heads numerous. $1-1 \frac{1}{2}$ in. wide; bracts narrowly lanceolate, pubescent; ray flowers 8-10, disk flowers purplish-black; scales awned, smooth, as long as the flowers; pappus a few minute scales. June-September. On open ground.

2. R. hirta L. Cone-Flower. Usually biennial; stem erect, rough-hairy, simple or branched, 2-3 ft. high; leaves lanceolate to oblong, thick, obscurely serrate, hispid, 3-ribbed, the lower petioled, the upper sessile; heads few, long-peduncled; bracts hispid, spreading; ray flowers 10-20, orange-yellow, disk flowers purplishbrown ; chaff acute, hairy at the apex; pappus none. May-August. On dry, open ground.

3. R. laciniata L. Tall Cone-flower. Perennial; stem smooth, branched, 3-10 ft. high; leaves thin, pubescent or roughened, the lower pinnately divided, the lobes irregularly cut and lobed, middle leaves 3-5-lobed or divided, the upper leaves often entire; heads few or many; bracts nearly equal; ray flowers $6-10$, yellow, $1-1 \frac{1}{2}$ in. long, disk flowers yellowish ; chaff truncate, pubescent at the apex, about as long as the achenes; pappus of very short scales. June-September. In damp woods.

\section{HELIANTHUS.}

Annual or perennial herbs; leaves opposite or alternate, undivided, usually 3-ribbed; heads radiate, few or many, solitary or corymbed; bracts in several series, the tips spreading or appressed; receptacle chaffy ; ray flowers neutral, disk flowers perfect, tubular; achenes oblong to obovate, compressed, 4-angled; pappus of 2-4 deciduous awns or scales. 
1. H. Axnuus L. Sunflower. Annual; stem erect, striate, hispid, branched above, 6-12 ft. high; leaves ovate to deltoid, 3-nerved, dentate, petioled, rough above, rough-pubescent beneath; heads terminating the branches, 4-10 in. wide; ray flowers numerous, yellow; disk flowers purple; chaff 3-cleft; achenes obovate, smooth or slightly pubescent. June-September. Native of the northwestern states; common in gardens.

2. H. divaricatus L. Woodlaxd Scnflower. Perennial, from a slender rootstock; stem slender, smooth, branched above, 2-5 ft. high; leaves opposite, ovate-lanceolate, acuminate at the apex, rounded at the base, serrate, very rough above, smooth or pubescent beneath; heads few, 1-3 in. wide, on short peduncles; bracts lanceolate to linear, spreading, as long as the disk; ray flowers 8-12, light yellow, disk flowers yellow; chaff entire or 3-toothed, pubescent at the apex; achenes obovate, smooth; pappus of 2 awns. July-September. Common in woods.

3. H. Decapetalus L. Wild Sunflower. Perennial, from a thickened rootstock; stem erect, slender, pubescent above, smooth below, branched, 2-5 ft. high; leaves ovate to ovate-lanceolate, thin, rough above, 3-nerved, acuminate at the apex, rounded at the base, coarsely serrate, short-petioled, the lower opposite, the upper alternate; heads many, yellow, $2-3$ in. wide; bracts lanceolate-linear, spreading, the outer longer than the disk; ray flowers 8-12; chaff 3 -toothed or entire, pubescent at the apex; achenes smooth; pappus of 2 slender awns. July-September. Common on damp soil.

\section{COREOPSIS.}

Annual or perennial herbs; leaves opposite or the upper alternate, entire or pinnately divided; heads radiate, solitary or corymbed, many-flowered; bracts in 2 rows of about 8 each, the inner membranaceous and appressed, the outer narrower and spreading; receptacle chaffy; ray flowers neutral, disk flowers tubular, perfect; achenes compressed, oval to oblong, often winged; pappus of 2 scales or bristles, or wanting.

1. C. tinctoria Nutt. Gardex Coreopsis. Annual; stem erect, smooth, branched, 2-3 ft. high; leares 2-3 times pinnately divided, the divisions linear, lower leaves petioled, the upper often sessile and entire; heads $1-1 \frac{1}{2}$ in. wide, on slender peduncles; inner bracts brown with scarious margins, outer bracts very short; ray flowers about 8, yellow with a brown base, 3-lobed at the apex; achenes linear; pappus minute or none. April-September. Common in gardens. 
2. C. Lanceolata L. Tickseed. Perennial; stem slender, erect or ascending, smooth or slightly pubescent below, simple, 9-15 in. high; leaves opposite, the lower spatulate to elliptical, sometimes lobed, on long, ciliate petioles, the upper lanceolate, sessile; heads few, on long peduncles; bracts ovate-lanceolate, the outer narrower; ray flowers $6-10$, rays 3 -õ-lobed, bright yellow; achenes oval, broadly winged, warty; pappus of 2 teeth. May-June. On rich, dry soil.

3. C. auriculata L. Runving 'Tickseed. Perennial; stem ascending or decumbent, weak, smooth, nearly simple, $6-15$ in. long; leaves ovate to oval, entire or with 2-4 small and rounded lobes at the base, pubescent, long-petioled; heads $1-1 \frac{1}{2}$ in. wide, few or single; outer bracts narrower than the inner; rays 6-10, mostly 4 -toothed at the apex; chaff as long as the flowers; achenes oblong, the wings narrow and thickened; pappus of 2 minute teeth. AprilMay. In rich woods.

\section{BIDENS.}

Annual or perennial; leaves opposite, simple or pinnately divided; heads radiate or discoid, corymbed; bracts in 2 series, the outer often long and leaf-like; receptacle chaffy; ray flowers neutral or wanting, disk flowers perfect; achenes flat or 4-angled; pappus of 2-4 downwardly barbed bristles.

1. B. Frondosa L. BegGar Ticks. Annual; stem erect, smooth or slightly pubescent, usually purple, branched, 2-5 ft. high; leaves pinnately 3-5-divided, the segments lanceolate to oval, acuminate, sharply serrate, thin; heads discoid, long-peduncled; outer bracts leaf-like; achenes flat, narrowly wedge-shaped, ciliate on the edges; pappus of 2 awns. June-September. A common weed.

2. B. Bipinvata L. Spanish Needles. Annual; stem erect, slender, smooth, 4-angled, branched, $2-5 \mathrm{ft}$. high; leaves bipinnate, the segments small, orate to lanceolate, acute, serrate; heads small, radiate; bracts narrow, nearly equal; ray flowers $2-4$, yellow, short; achenes linear, 4-angled, slightly pubescent; pappus of 4 barbed awns. July-September. A common weed.

\section{HELENIUM.}

Annual or perennial; leaves alternate, decurrent on the stem; heads radiate, peduncled, many-flowered; bracts in 2 series, the outer linear and spreading, the inner few and scale-like; receptacle naked, convex or oblong; ray flowers 
pistillate and fertile, or neutral, the rays cuneate, 3-5-lobed, disk flowers perfect, tubular, 4-5-lobed; achenes top-shaped, hairy, ribbed; pappus of 4-5 entire, toothed or awned scales.

1. H. nudiflorum Nutt. Snezzeweed. Perennial; stem slender, erect, pubescent, branched above, 1-2 ft. high; leaves lanceolate, entire or slightly toothed, the lower petioled, the upper sessile; heads numerous, ray flowers $10-15$, neutral, yellow or yellow and brown, disk flowers purple; achenes hairy on the ribs; pappus of ovate, denticulate, awned scales. May-June. Common on river banks.

2. H. tendifolium Nutt. Bitterweed. Annual ; stem erect, widely branched, smooth, 1-2 ft. high; leaves very numerous, filiform, sessile; heads on long and slender peduncles; bracts subulate, soon reflexed; ray flowers 4-8, fertile, the rays drooping; pappus of ovate, entire, awned scales. June-October. A troublesome roadside and pasture weed.

\section{ACHILLEA.}

Perennial; leaves alternate, pinnately divided; heads radiate in a terminal corymb; involucral bracts imbricated in several series, the outer shorter; receptacle chaffy; ray flowers white or pink, pistillate and fertile, disk flowers perfect, tubular, 5-lobed; achenes oblong, compressed, slightly margined; pappus none.

A. Millefolicir L. Yarrow. Stems often clustered, erect from a creeping rootstock, simple, pubescent or tomentose, 1-2 ft. high;. leaves lanceolate or oblong, the segments finely cut and divided, smooth or pubescent, the lower petioled, the upper sessile; heads small, numerous, in flat-topped corymbs; bracts pubescent; ray flowers $4-5$, white or pink, rays 3 -lobed at the apex. MaySeptember. Common in old fields.

\section{SENECIO.}

Annual or perennial; stems often hollow ; leaves alternate, entire or pinnately divided; heads radiate or discoid, in terminal corymbs; bracts mostly in a single row, often with a few shorter ones at the base ; receptacle naked or pitted; ray flowers yellow or orange, pistillate and fertile when present, disk flowers tubular, perfect; achenes terete or compressed, 
not beaked or winged, 5-10-ribbed, pubescent; pappus of numerous, slender, white hairs.

1. S. tomentosus Michx. Woolly Ragweed. Perennial; woolly throughout; stem stout, erect, mostly simple, $2-3 \mathrm{ft}$. high; lower leaves ovate to oblong, crenate or entire, obtuse, long-petioled, stem leaves few, elliptical to oblanceolate, serrate or toothed, acute, sessile; heads radiate, $\frac{3}{4}$ in. wide, on slender peduncles; bracts narrow, becoming smooth; ray flowers $12-15$, yellow; achenes hairy. April-June. On damp soil.

2. S. Aureus L. Golden Ragweed. Perennial; stems often tufted, erect, slender, woolly when young, branched above, 18-30 in. high; lower leaves broadly ovate, obtuse at the apex, cordate at the base, crenate, long-petioled; stem leaves lanceolate and often pinnatifid, the upper small and sessile; heads radiate, corymbed, on slender peduncles; ray flowers $8-12$, bright yellow; achenes smooth. May-July. On wet soil; very variable.

3. S. Lobatus Pers. Butterweed. Annual; stem erect, ridged, hollow, often woolly when young, and becoming smooth with age, branched above, 1-3 ft. high; leaves lyrate-pinnatifid, thin, the lower petioled, the upper sessile; heads radiate in a terminal corymb; bracts linear, acute; ray flowers about 12, yellow; achenes slightly hispid on the angles; pappus scabrous, longer than the involucre. March-May. Common on low ground.

\section{CARDUUS.}

Biennial or perennial; stem ereet, simple or branched; leaves alternate, prickly, often decurrent; heads discoid, terminal and solitary or corymbed, many-flowered; -bracts imbricated in many series, the outer shorter, usually spinepointed; receptacle bristly ; corollas purplish or nearly white, the tube slender, deeply 5-cleft; achenes oblong, 4-angled, smooth or ribbed; pappus of numerous simple or plumose bristles.

1. C. altissinus L. Tall Thistle. Perennial or biennial; stem stout, very leafy, pubescent or tomentose, branched, 4-10 ft. high; leaves rough-pubescent above, hoary beneath, fringed with fine prickles, not decurrent, the lower petioled and often pinnatifid, the upper sessile and entire; heads ovoid, 1 in. in diameter; bracts viscid, webby when young, all except the inner ones tipped with weak and spreading bristles; flowers light purple. July-September. Common in fields and.waste places. 
2. C. Spinosissimus Walt. Yellow Thistle. Biennial or perennial; stem erect, stout, woolly when young, becoming smooth, often purple, branched, 1-3 ft. high; leaves pinnatifid, with very spiny teeth, mostly sessile and clasping, smooth and green on both sides; heads large, surrounded by a whorl of linear-oblong, pectinate leaves; involucral bracts linear, ciliate, not spine-tipped; flowers purple or yellowish. April-June. On sandy soil.

\section{THYRSANTHEMA.}

Perennial, acaulescent herbs; leaves green above, whitetomentose beneath; scapes single or few, each bearing a single head of white or purplish flowers; heads radiate, manyflowered; bracts imbricated in several rows, appressed, the outer shorter; receptacle naked; ray flowers in 2 rows, pistillate and fertile, the outer ligulate, entire or 3 -toothed at the apex, the inner 3-5-toothed, filiform, disk flowers perfect but sterile, the corolla bilabiate, 5-toothed; styles entire; achenes oblong, 5-nerved; pappus of numerous white hairs.

T. semiflosculare (W'alt.) Kuntze. Spring Daisy. Leaves narrowly oval to spatulate, nearly prostrate, smooth above, densely white-woolly beneath, entire; scapes leafless, erect, slender, tomentose, 6-12 in. high; heads about $1 \mathrm{in.}$ wide, nodding in the bud, becoming erect in flower; bracts lanceolate to linear; rays broadly linear, pinkish-purple; achenes narrowed at each end. smooth; pappus of numerous bristle-like hairs. February-April. Very common on low ground. 



\section{GLOSSARY OF TERMS USED IN DESCRIPTIONS.}

Abortive. Rudimentary or imperfect.

Abruptly pinnate. With two terminal leaflets.

Acaulescent. The stem not rising above the surface of the ground.

Appressed. Pressed closely to the main body.

Aril. An additional, usually fleshy, growth surrounding the seed. Aristate. Awned.

A uriculate. Furnished with rounded, ear-like lobes.

Baccate. Fleshy or berry-like.

Bipinnate. Bipinnatifid. Twice pinnate, or twice pinnatifid.

Biternate. Twice ternate, or twice three-parted.

Caducous. Dropping off as soon as fully grown.

Campanulate. Bell-shaped.

Canescent. Hoary or grayish white.

Caruncle. An excrescence at the scar of some seeds.

Ciliate. With hairs on the margins.

Circinate. Rolled inward from the top.

Coma. A tuft of hairs.

Connate. Grown together.

Connivent. Converging, drawn together.

Coriaceous. Leathery or chaffy in texture.

Cuneate. Wedge-shaped.

Declined. Turned to one side.

Decurrent. Continued downward along the stem.

Depressed. Flattened from the apex.

Didynamous. In two pairs of unequal length.

Distinct. Wholly separate from each other.

Dorsal. Pertaining to the back.

Equal. Of the same size and shape. 
Exfoliate. Peeling off in plates.

Exserted. Protruding beyond the surrounding envelop.

Fimbriate. Fringed.

Fusiform. Spindle-shaped.

Gibbous. Swelled on one side.

Glabrous. Smooth.

Glaucous. Covered with bloom, as a cabbage leaf.

Hirsute. Hairy with long, straight hairs.

Hispid. Bristly with stiff hairs.

Hoary. See Canescent.

Inflated. Swollen and bladder-like.

Lenticular. Nearly flat, but somewhat convex on both sides.

Nodulose. Knobbed.

Odd-pinnate. With a single, terminal leaflet.

Puberulent. Very minutely downy.

Pubescent. Hairy with short, fine, and soft hairs.

Punctate. Minutely dotted.

Reticulated With a network of veins.

Rosulate. Flat, roselike.

Rugose. Roughened with wrinkles.

Saprophytic. Living on dead vegetable matter.

Scabrous. Rough.

Scape. A peduncle arising from the surface of the ground.

Scarious. Thin and papery.

Sessile. Not stalked.

Setaceous. Bristle-like.

Sinus. The space between two lobes.

Stipe. The stalk of a pistil or ovary.

Subulate. Awl-shaped.

Terete. Cylindrical.

Tomentose. Clothed with woolly hairs.

Torulose. Twisted.

Villous. Clothed with long and soft hairs. 


\section{N D E X.}

Abutilon, 147.

Acacia, 111.

Acacia, Crimson, 111.

ACanthacee, 217.

Acanthus Family, 217.

Acer, 141.

Acerace 140.

Achillea, 245.

Actra, 77.

Acuan, 110.

Adopogon, 232.

Asculus, 141.

Agave, 39.

Agrimonia, 104.

Agrimony, 104.

Agrostemma, 69.

Ailanthus, 133.

Ailanthus Family, 133.

Alder, Smooth, 51.

Aletris, 32.

Alfalfa, 118.

Alisma, 16.

Alismace e, 16.

Allium, 29.

Alnus, 50.

Aloe, American, 40.

Aloe, False, 40.

Althæa, 146.

Althea, Shrubby, 148.

Amarantace e, 66.

Amaranth Family, 66.
Amaranth, Spiny, 67.

Amaranthus, 66.

Amaryllidace e, 38.

Amaryllis, 38.

Amaryllis Family, 38.

Amelanchier, 107.

Amorpha, 120.

Ampelopsis, 144.

Amsonia, 184.

Amsonia, Narrow-leaved, 185.

Amygdalus, 109.

Anacardiacex, 137.

Anagallis, 174.

Anemone, 79.

Anemone, Carolina, 79.

Anemone, Virginia, 79.

Anemone, Wood, 79.

Angiosperme, 15.

Anise, 74 .

Anonace 75 . 75 .

Antirrhinum, 209.

Apios, 127.

Apocynace e, 184.

Apocynum, 185.

Apple, 105.

Apple Family, 105.

Aquilegia, 78.

Aracee, 21.

Aralia, 161.

Araliaces, 161.

Arisæma, 21. 
Aristolochia, 61.

Aristolochiacee, 60.

Arrow-arum, Green, 22.

Arrowhead, Broad-leaved, 17.

Arrow-wood, 224.

Arrow-wood, Maple-leaved, 224.

Arrow-wood, Rough, 224.

Arum Family, 21.

Asarum, 60.

Asarum, Virginia, 60.

Asclepiadace 186.

Asclepias, 187.

Asclepias, Pine-barren, 187.

Ascyrum, 150.

Ash, Red, 178.

Ash, Water, 179.

Ash, White, 178.

Asimina, 75.

Asparagus, 34 .

Aster, 239.

Aster, Blue, 239.

Aster, Bushy, 240.

Aster, Purple, 240.

Aster, Silvery, 240.

Aster, Wavy-leaved, 239.

Atamasco Lily, 38.

Azalea, 168.

Baldwin's Pink, 70.

Baneberry, 77.

Baptisia, 115.

Barberry Family, 83.

Basswood, 145.

Bay-berry Family, 46.

Bean, Trailing, 129.

Bean, Wild, 128.

Beard-tongue, Gray, 211.

Beard-tongue, Hairy, 210.

Bedstraw, 223.

Bedstraw, Hairy, 222.

Beech, 51.
Beech Family, 51.

Beggar Ticks, 244.

Beggar-weed, Hoary, 124.

Beggar-weed, Naked-flowered, 124.

Beggar-weed, Pointed-leaved, 124.

Bell-flower Family, 228.

Bell-flower, Tall, 229.

Bellwort, Large-flowered, 28.

Bellwort, Perfoliate, 28.

Bellwort, Sessile-leaved, 28.

Benzoin, 86.

Berberidacese, 83.

Berchemia, 142.

Bergamot, Wild, 204.

Betula, 50.

Betulacee, 48.

Bidens, 244.

Bignonia, 215.

Bignonia Family, 215.

Bignoniace e, 215.

Bindweed, 191.

Bindweed, Blue, 191.

Birch, Black, 50.

Birch, Cherry, 50.

Birch Family, 48.

Birthwort Family, 60.

Bitterbloom, 182.

Bittercress, Hairy, 90.

Bitterweed, 245.

Blackberry, 102.

Blackberry, Sand, 102.

Black Gum, 166.

Black Haw, 224.

Bladderwort Family, 213.

Bladderwort, Horned, 214.

Bladderwort, Small, 214.

Bladderwort, Swollen, 214.

Blazing Star, 237.

Biazing Star, Showy, 238.

Blood Root, 87.

Bloodwort Family, 37. 
Blueberry, High-bush, 173.

Blue Curls, 202.

Blue-eyed Grass, 42.

Blue-eyed Grass, Eastern, 43.

Bluets, 220.

Bluets, Large, 220.

Bluets, Long-leaved, 221.

Bluets, Small, 220.

Bœhmeria, 59.

Boneset, 237.

Boneset, Purple, 237.

Borage Family, 196.

BoraginaCee, 196.

Bouncing Bet, 71 .

Box Elder, 141.

Bradburya, 126.

Breweria, 189.

Bridal Wreath, 101.

Bromelaced, 23.

Broussonetia, 57.

Brunnichia, 64.

Buckeye Family, 141.

Buckeye, Red, 141.

Buckthorn, Carolina, 142.

Buckthorn Family, 142.

Buckwheat, False, 63.

Buckwheat Family, 61.

Bur Clover, 118.

Bursa, 90.

Butneria, 85 .

Buttercup, Small-flowered, 81.

Buttereup, Tufted, 82.

Butterfly-weed, 187.

Butternut, 45.

Butterweed, 246.

Button-bush, 221.

Button Snake-root, 238.

Button Snake-root, Spiked, 238.

Buttonwood, 99.

Cactacee, 154.
Cactus, Crowfoot, 155.

Cactus Family, 154.

Cesalpinace 112.

Calico Bush, 169.

Callicarpa, 200.

Callirrhoë, 146.

Caltha, 77.

Calycanthace e, 84.

Calycocarpum, 84.

Camellia, 149.

Campanula, 229.

Campandlacee, 228.

Caper Family, 92.

Capnoides, 88.

Capparidacee, 92.

Caprifoliace , 223.

Cardamine, 90.

Cardinal Flower, 230.

Carduus, 246.

Carpinus, 48.

Carrion Flower, 36.

Carrot, Wild, 163.

Caryophyllace.e, 69.

Cassia, 112.

Castalia, 72.

Castanea, 52.

Castor Bean, 136.

Catalpa, 216.

Catgut, 121.

Cat-tail, 16.

Cat-tail Family, 15.

Cebatha, 83.

Cedar, Red, 15.

Celastrace 140.

Celtis, 55 .

Cephalanthus, 221.

Cerastium, 71.

Cercis, 112.

Chamælirium, 27.

Chaste Tree, 201.

Cheeses, 146. 
Chelone, 210.

Chenopodiace 64 .

Chenopodium, 65.

Cherry, 109.

Cherry, Laurel, 109.

Cherry, Wild Black, 109.

Chestnut, American, 52.

Chickweed, Mouse-eared, 71.

Chicory Family, 231.

Chinquapin, 52.

Chionanthus, 179.

Chrosperma, 27.

Chrysobalanus, 110.

Cichoriace 231.

Cinquefoil, 103.

Cistacee, 151.

Citron, 228.

Claytonia, 68.

Clematis, 80.

Clematis, Marsh, 80 .

Cleome, 92.

Clethra, 167.

Clethraces, 167.

Cliftonia, 139.

Clitoria, 127.

Clover, Buffalo, 119.

Clover, Carolina, 119.

Clover, Crimson, 119.

Clover, Japan, 125.

Clover, Low Hop, 119.

Clover, Red, 119.

Clover, White, 119.

Cockspur Thorn, 107.

Coffee-weed, 122.

Coffee-weed, Long-pod, 123.

Colchicum Family, 26.

Colic Root, 32.

Colic Root, Yellow, 32.

Columbine, 78.

Columbine, European, 78.

Columbo, American, 184.
Comfrey, Wild, 197.

Commelina, 24.

Commelinace 24.

Compass Plant, 241.

Composit ж, 234.

Cone-flower, 242.

Cone-flower, Tall, 242.

Cone-flower, Thin-leaved, 242.

Convallariace 233.

Convolvulace 188.

Convolvulus, 191.

Coral Berry, 225.

Coral Plant, 129.

Coreopsis, 243.

Coreopsis, Garden, 243.

Cornace 165.

Corn Cockle, 70.

Corn Salad, 227.

Cornus, 165.

Corylus, 49.

Cotinus, 138.

Cotton, 148.

Cottonwood, 47.

Crab-apple, 106.

Cracca, 120.

Crane's-bill, Carolina, 130.

Crane's-bill, Wild, 130.

Crape Myrtle, 156.

Crassulacee, 95.

Cratægus, 107.

Cress, Bulbous, 90.

Crinum, 39.

Cross-vine, 215.

Crotalaria, 116.

Crowfoot, Bristly, 81 .

Crowfoot, Creeping, 82.

Crowfoot Family, 76.

Crowfoot, Hooked, 81.

Crowfoot, Small-flowered, 81.

Crucifere, 88.

Cucumber, Creeping, 228. 
Cucumber, Star, 228.

Cucurbita, 227.

Cucurbitace 227.

Culver's Root, 212.

Cupseed, 84.

Currant, Red, 98.

Custard Apple Family, 75.

Cydonia, 107.

Cynoglossum, 197.

Cyperacex, 19.

Cypress, Bald, 14.

Cypress Vine, 190.

Cyrilla, 138.

Cyrillace 138.

Cyrilla Family, 138.

Dandelion, 233.

Dandelion, False, 234.

Dasystoma, 212.

Datura, 207.

Daucus, 163.

Dayflower, Bearded, 24.

Dayflower, Virginia, 24.

Day Lily, 29.

Deerberry, 173.

Deer Grass, 157.

Deer-tongue, 238.

Delphinium, 78.

Desmanthus, 111.

Dewberry, 102.

Dianthera, 218.

Dianthus, 71.

Dichondra, 189.

Dicotyledons, 44.

Diervilla, 226.

Diodia, 222.

Diospyros, 175.

Dirca, 155.

Ditch Stonecrop, 95.

Dock, Bitter, 62.

Dock, Swamp, 62.
Dodecatheon, 175.

Dogbane Family, 184.

Dog-tooth Violet, Yellow, 31.

Dogwood, Alternate-leaved, 166.

Dogwood Family, 165.

Dogwood, Flowering, 165.

Dogwood, Rough-leaved, 166.

Dragon Root, 22.

Drosera, 94.

Droserace

Drupace e 108.

Duchesnea, 103.

Dutchman's Breeches, 88.

Dutchman's Pipe, 61.

Ebenace 175.

Ebony Family, 175.

Elder, 223.

Elephantopus, 236.

Elephant's Foot, Carolina, 236.

Elephant's Foot, Woolly, 236.

Elm Family, 54.

Elm, Slippery, 55.

Elm, White, 55.

Elm, Winged, 55.

Epigæa, 171.

Ericace 168.

Erigeron, 240.

Eryngium, 164.

Erythrina, 129.

Erythronium, 31.

Euonymus, 140.

Eupatorium, 236.

Euphorbia, 136.

Euphorbiaces, 135.

Evening Primrose, 159.

Evening Primrose Family, 158.

FaGaCe $\mathbb{E}, 51$.

Fagus, 51.

Farkleberry, 173. 
Fetterbush, 170.

Fig, 58.

Figwort Family, 208.

Flag, Large Blue, 41.

Flag, Southern Blue, 42.

Flag, Yellow, 42.

Fleabane, 240.

Fleabane, Daisy, 240.

Fleabane, Early, 241.

Fleur-de-lis, 42.

Fly Poison, 27.

Fog-fruit, 200.

Forget-me-not, 197.

Forget-me-not, Small, 197.

Foxglove, Downy False, 212.

Foxglove, Smooth False, 213.

Fragaria, 103.

Frasera, 183.

Fraxinus, 178.

Fringe Tree, 179.

Frœlichia, 67.

Frost-weed, 152.

Fuchsia, 161.

Galactia, 127.

Galium, 222.

Gaura, 160.

Gaura, Biennial, 160.

Gaura, Michaux's, 160.

Gaylussacia, 172.

Gelsemium, 180.

Gentiana, 183.

Gentianace e, 181.

Gentian, Elliott's, 183.

Gentian Family, 181.

Gentian, Narrow-leaved, 183.

Geraniace e, 129.

Geranium, 130.

Geranium Family, 129.

Geranium, Horse-shoe, 130.

Geranium, Rose, 131.
Gerardia, 213.

Gerardia, Flax-leaved, 213.

Gerardia, Purple, 213.

Germander, 201.

Geum, 104.

Gilia, 193.

Gilia, Scarlet, 193.

Ginger Root, 60.

Ginseng, 162.

Ginseng Family, 161.

Glasswort, 65 .

Glecoma, 203.

Gleditsia, 113.

Glottidium, 122.

Goat's-beard, 232.

Goat's-beard', Carolina, 232.

Goat's Rue, 121.

Golden Club, 23.

Golden-rod, Blue-stemmed, 239.

Golden-rod, Canadian, 239.

Golden-rod, Field, 239.

Gooseberry Family, 97.

Gooseberry, Smooth, 98.

Gooseberry, Wild, 98.

Goosefoot Family, 64 .

Goosegrass, 222.

Gourd, 228.

Gourd Family, 227.

Graminex, 17.

Grape Family, 143.

Grape, Fox, 143.

Grape, Muscadine, 144.

Grape, Summer, 143.

Grass Family, 17.

Grass of Parnassus, 96.

Greenbrier, Bristly, 36.

Greenbrier, Glaucous, 36.

Greenbrier, Laurel-leaved, 37.

Greenbrier, Walter's, 37.

Gromwell, Carolina, 198.

Gromwell, Field, 198. 
Gromwell, Virginia, 199.

Grossulariace 97.

Ground Cherry, Hairy, 205.

Ground Cherry, Sticky, 205.

Ground Cherry, Wild, 205.

Ground Ivy, 203.

Ground Nut, 127.

Gymosperma, 13.

Gyrotheca, 37.

Hackberry, 56.

Hackberry, Southern, 56.

HAMODORACEA, 37.

Hamamelidace $2,98$.

Hamamelis, 98.

Hardhack, 101.

Haw, Cut-leaved, 108.

Haw, Small-fruited, 108.

Haw, Yellow, 108.

Hazel-nut, 50.

Heath Family, 168.

Hedge Mustard, 91.

Helenium, 244.

Helianthemum, 152.

Helianthus, 242.

Heliotrope, Indian, 196.

Heliotrope, Seaside, 196.

Heliotropium, 196.

Hemerocallis, 29.

Hepatica, 79.

Hercules's Club, 132, 161.

Hesperis, 91.

Hibiscus, 148.

Hibiscus, Swamp, 148.

Hickory, Pig-nut, 46.

Hickory, Scaly-bark, 46.

Hicoria, 45.

Hippocastanace 141.

Hog Plum, 110.

Holly, 139.

Holly, Deciduous, 139.
Holly Family, 139.

Hollyhock, 146.

Honey Locust, 113.

Honeysuckle, Coral, 225.

Honeysuckle Family, 223.

Honeysuckle, Japan, 225.

Honeysuckle, Swamp, 169.

Honeysuckle, Wild, 169.

Honeysuckle, Yellow, 225.

Hop-tree, 132.

Hop-vine, 58.

Hornbeam, 49.

Houstonia, 220.

Huckleberry, Dwarf, 172.

Huckleberry Family, 171.

Humulus, 58 .

Hyacinth, 30 .

Hyacinthus, 30.

Hydrangea, 96.

Hydrangea, Downy, 96.

Hydrangea, Garden, 97.

Hydrangea, Oak-leaved, 97.

HydRophyllaCE 194.

Hydrophyllum, 194.

Hymenocallis, 39.

Hypericace e, 150.

Hypericum, 150.

Hypopitys, 168.

Hypoxis, 40.

Ilex, 139.

ILICACE 139.

Illicium, 74 .

Indian Cucumber-root, 35 .

Indian Hemp, 185.

Indian Pipe, 168.

Indian Pipe Family, 167.

Indian Turnip, 22.

Indigo, Blue False, 116.

Indigo, False, 120.

Indigofera, 122. 
Indigo, Narrow-leaved, False, 116. Indigo, White Wild, 116.

Indigo, Wild, 116, 122.

Ipecac, American, 101.

Ipomœe, 190.

IRIDACE $\mathbb{E}, 41$.

Iris, 41.

Iris Family, 41.

Ironwood, Bastard, 132.

Isopyrum, 77.

Itea, 96.

Jatropha, 136.

Jessamine, Yellow, 181.

Jimson-weed, 207.

Jimson-weed, Purple, 207.

JugLandaCe $\boldsymbol{x}, 44$.

Juglans, 45.

JUNCACEA, 26.

Juniperus, 15.

Jussiæa, 159.

Jussiæa, Upright, 159.

Kalmia, 169.

Kinnikinnik, 166.

Kneiffia, 160.

Knot-grass, 63.

Koniga, 91.

Krauhnia, 121.

Labiatze, 201.

Lacinaria, 237.

Lady's Tear-thumb, 63.

Lagerstrœmia, 156.

Lamb Lettuce, 226.

Larkspur, Blue, 78.

Larkspur, Garden, 78.

Lathyrus, 126.

Latuca, 233.

LAURACE

Laurel Family, 85 .
Laurel, Ground, 171.

Laurel, Sheep, 169.

Lead Plant, 120.

Leather Flower, 80.

Leatherwood, 138, 156.

Legouzia, 229.

LentibUla CE E, 213.

Lepidium, 89.

Leptandra, 212.

Lespedeza, 124.

Lespedeza, Bush, 125.

Lespedeza, Creeping, 125.

Lettuce, Blue, 234.

Lettuce, Wild, 233.

Leucothoë, 170.

Leucothoë, Downy, 170.

Leucothoë, Swamp, 170.

Licorice, Wild, 223.

Ligustrum, 179.

LILIACE 28.

Lilium, 30.

Lily, Carolina, 31.

Lily Family, 28.

Lily-of-the-Valley Family, 33.

Lily, Southern Red, 31.

Lily, Tiger, 31.

Linaria, 209.

Linden Family, 145.

Lippia, 200.

Liquidambar, 99.

Liriodendron, 75.

Lithospermum, 198.

Liver-leaf, 79.

Lizard-tail, 44.

Lizard-tail Family, 44.

Lobelia, 230.

Lobelia, Blue, 230.

Lobelia, Spiked, 231.

Lobelia, Swamp, 230.

Locust, Black, 122.

Loganiace.e, 180. 
Logania Family, 180.

Lonicera, 225.

Loosestrife Family, 156.

Loosestrife, Fringed, 174.

Loosestrife, Lance-leaved, 174.

Lophiola, 40.

LORANTHACEA, 59.

Lotus, American, 73.

Ludwigia, 158.

Ludwigia, Hairy, 158:

Ludwigia, Winged, 158.

Lupine, Woolly, 117.

Lupinus, 117.

Lycium, 207.

Lycopersicon, 206.

Lythracee, 156.

Madder Family, 220.

Magnolia, 73.

Magnoliace $2,73$.

Magnolia Family, 73.

Magnolia, Large-flowered, 73.

Mallow, Bristly, 148.

Mallow, Halberd-leaved, 148.

Mallow, Poppy, 146.

Mallows Family, 145.

Malus, 106.

Malva, 146.

Malvacea, 145.

Maple Family, 140.

Maple, Red, 141.

Maple, Sugar, 141.

Marsh Marigold, 77.

Marsh Violet, Purple, 215.

Marsh Violet, Yellow, 215.

Martynia, 217.

Martyniace $2,216$.

Matrimony Vine, 207.

May Apple, 83.

Meadow-beauty, 157.

Meadow-beauty Family, 157.
Meadow-beauty, Smooth, 157.

Meadow-beauty, Yellow, 158.

Meadow Garlic, 30.

Meadow Rue, 82.

Medeola, 34.

Medicago, 117.

Meibomia, 124.

Melanthace 26.

Melastomace 157.

Melia, 133.

Meliacee, 133.

Melia Family, 133.

Melilotus, 118.

Melothria, 228.

Menispermaces, 83.

Menispermum, 84.

Mezereon Family, 155.

Mignonette, 93.

Mignonette Family, 92.

Milkweed Family, 186.

Milkweed, Thin-leaved, 188.

Milkweed, White, 187.

Milkwort Family, 134.

Milkwort, Low Yellow, 134.

Milkwort, Orange, 134.

Milkwort, Pink, 135.

Milkwort, Racemed, 135.

Milkwort, Showy, 135.

Mrmosace e, 110.

Mimosa Family, 110.

Mimulus, 211.

Mint Family, 201.

Mint, Horse, 204.

Mist Flower, 237.

Mistletoe, 60.

Mistletoe Family, 59.

Mitchella, 221.

Modiola, 148.

Mohrodendron, 177.

Monarda, 204.

Monkey Flower, Sharp-winged, 212. 
Monkey Flower, Square-stemmed, 211.

Monocotyledons, 15.

Monotropa, 167.

Monotropace 167.

Moonseed, 84.

Moonseed, Carolina, 84.

Moonseed Family, 83.

Moracez, 56.

Morning-glory, 191.

Morning-glory Family, 188.

Morning-glory, Marsh, 191.

Morning-glory, Small Red, 190.

Morongia, 111.

Morus, 56.

Mulberry Family, 56.

Mulberry, French, 200.

Mulberry, Paper, 57.

Mulberry, Red, 56.

Mulberry, White, 57.

Mullein, Moth, 209.

Muskmelon, 228.

Mustard Family, 88.

Mustard, Hedge, 91.

Myosotis, 197.

Myrica, 46.

MYricacee, 46.

Nama, 195.

Nama, Hairy, 195.

Nama, Ovate-leaved, 196.

Nelumbo, 73.

Nemophila, 195.

Nemophila, Small-flowered, 195.

Nerium, 186.

Nettle, False, 59.

Nettle Family, 58.

Nettle, Horse, 206.

Nettle, Large Stinging, 58.

Nettle, Small, 59.

Nightshade, 206.
Ninebark, 100.

Nymphæa, 72.

NyMPHEACE 72.

Nyssa, 166.

Oak, Black, 53.

Oak, Black Jack, 53.

Oak, Live, 54.

Oak, Post, 54.

Oak, Red, 53.

Oak, Spanish, 53.

Oak, Swamp, 54.

Oak, Swamp Chestnut, 54 .

Oak, White, 53.

Oak, Willow, 53.

Oak, Yellow Chestnut, 54.

Okra, 148.

Olea, 180.

Oleace 178.

Oleander, 186.

Olive, American, 180.

Olive Family, 178.

Olive, Sweet, 180.

Onagra, 159.

Onagrace 158.

Onosmodium, 198.

Opoponax, 111.

Opulaster, 100.

Opuntia, 155.

OrChidaces, 43.

Orchis Family, 43.

Ornithogalum, 32.

Orontium, 23.

Orpine Family, 95.

Osage Orange, 57.

Ostrya, 49.

Oxalidacea, 131.

Oxalis, 131.

Oxydendrum, 171.

Pæonia, 82.

Pæony, Garden, 82 . 
Palmetto, Blue, 21.

Palmetto, Dwarf, 20.

Palmetto, Saw, 21.

Palm Family, 20.

Panax, 162.

Pansy, 153.

Pansy, Field, 153.

Papaver, 87.

Papaverace 87.

Papilionace 114.

Parnassia, 96.

Parsley Family, 162.

Parsnip, 164.

Parsnip, Hairy Meadow, 164.

Parthenocissus, 144.

Passiflora, 154.

Passiflorace e, 154.

Passion-flower, 154.

Passion-flower Family, 154.

Passion-flower, Yellow, 154.

Pastinaca, 163.

Paulownia, 211.

Pawpaw, 75.

Pawpaw, Dwarf, 76.

Pea, Butterfly, 127.

Peach, 110.

Pea Family, 114.

Pear, 106.

Pea, Spurred Butterfly, 126.

Pecan, 45.

Pelargonium, 130.

Peltandra, 22.

Penthorum, 95.

Pentstemon, 210.

Peppergrass, 89.

Pepper-vine, 144.

Periwinkle, 185.

Persea, 85.

Persimmon, 175.

Phaseolus, 128.

Philadelphus, 97.
Phlox, 192.

Phlox, Downy, 192.

Phlox, Drummond's, 193.

Phlox Family, 192.

Phlox, Garden, 192.

Phlox, Wild Blue, 193.

Phoradendron, 59.

Physalis, 204.

Phytolacca, 68.

Phytolaccace e, 67.

Pickerel-weed, 26.

Pickerel-weed Family, 25.

Pieris, 170.

Pigweed, 65.

Pigweed, Slender, 66.

Pinace e, 13.

Pineapple Family, 23.

Pine Family, 13.

Pine, Loblolly, Oldfield, 14.

Pine, Long-leaved, 13.

Pine-sap, 168.

Pine, Scrub, 14.

Pineweed, 151.

Pinguicula, 214.

Pink Family, 69.

Pink, Marsh, 182

Pink, Pine-woods, 182.

Pinkroot, 181.

Pink, Slender Marsh, 182.

Pinus, 13.

Pitcher-plant Family, 93.

Pitcher-plant, Small, 94.

Plantaginace e, 219.

Plantago, 219.

Plantain, 219.

Plantain Family, 219.

Plantain, Large-bracted, 219.

Plantain, Many-seeded, 219.

Plantain, Water, 16.

Platanacee, 99.

Platanus, 99. 
Plum, Chickasaw, 109.

Plum Family, 108.

Plum, Wild, 109.

Podophyllum, 83.

Poison Vine, 137.

Pokeweed, 68.

Pokeweed Family, 67.

Polemoniacex, 192.

Polemonium, 193.

Polygala, 134.

Polygalacee, 134.

Polygonacee, 61.

Polygonatum, 34.

Polygonum, 62.

Pomace 105.

Pond Lily, Yellow, 72.

Pomegranate, 157.

Pontederia, 25.

Pontederiace e, 25.

Poor Man's Weather-glass, 174.

Poppy, Corn, 87.

Poppy Family, 87.

Poppy, Opium, 87.

Populus, 47.

Porteranthus, 101.

Portulaca, 69.

Portulacace e, 68.

Portulaca, Garden, 69.

Potato Family, 204.

Potato, Irish, 206.

Potato Vine, Wild, 190.

Potentilla, 103.

Poverty-weed, 222.

Poverty-weed, Large, 222.

Prairie Dock, 241.

Prickly Pear, 155.

Primrose Family, 173.

Primrose, Narrow-leaved, 160.

Primulace 173.

Prince's Feather, 63.

Privet, 179.
Prunus, 108.

Psoralea, 119.

Ptelea, 132.

Puccoon, Hairy, 198.

Punica, 156.

Purslane, 69.

Purslane Family, 68.

Pyrus, 106.

Quamoclit, 190.

Quercus, 52.

Quince, 107.

Quince, Japan, 107.

Ragweed, Golden, 246.

Ragweed, Woolly, 246.

RanunCulacee, 76.

Ranunculus, 81.

Raphidophylla, 21.

Raspberry, Black, 102.

Raspberry, Red, 102.

Rattan-vine, 142.

Rattle-box, 117, 159.

Rattle-box, Narrow-leaved, 117.

Red Bay, 85.

Redbud, 112.

Red Root, 37.

Reseda, 93.

RESEDACE 92.

Rhamacee, 142.

Rhamnus, 142.

Rhexia, 157.

Rhus, 137.

Rhynchosia, 128.

Rhynchosia, Climbing, 128.

Rhynchosia, Round-leaved, 128.

Ribes, 98.

Ribgrass, 219.

Ricinus, 135.

Robinia, 121.

Rock-rose, Carolina, 152. 
Rock-rose Family, 151.

Roripa, 89.

Rosa, 104.

ROSACE 100.

Rose, Cherokee, 105.

Rose, Climbing, 105.

Rose Family, 100.

Rose, Pasture, 105.

Royal Catchfly, 70.

Rubiacese, 220.

Rubus, 102.

Rudbeckia, 242.

Rue Anemone, 80.

Rue Family, 131.

Ruellia, 217.

Ruellia, Hairy, 218.

Ruellia, Smooth, 218.

Rumex, 62.

Rush Family, 26.

RUtaCex, 131.

Sabal, 20.

Sabalace e 20.

Sabbatia, 182.

Sabbatia, Large-leaved, 182.

Sage, Garden, 203.

Sage, Scarlet, 203.

Sagittaria, 17.

Sagittaria, Grass-leaved, 17.

SAlicace 47.

Salicornia, 65 .

Salix, 48.

Salsola, 66.

Saltwort, 66.

Salvia, 203.

Salvia, Lyre-leaved, 203.

Sambucus, 223.

Sand Bur, 206.

Sanguinaria, 87.

Sanicula, 165.

Saponaria, 71.
Sarothra, 151.

Sarracenia, 93.

Sarraceniace e, 93.

Sarsaparilla, 162.

Sassafras, 86.

Saururace 4 , 44.

Saururus, 44.

SAXifragace $2,95$.

Saxifrage Family, 95.

Scrophulariaceze, 208.

Scutellaria, 202.

Sedge Family, 19.

Senecio, 245.

Senna, Coffee, 112.

Senna Family, 112.

Senna, Low, 112.

Sensitive Brier, 111.

Sensitive Plant, Large-flowered,

113.

Sensitive Plant, Wild, 113.

Serenoa, 20.

Serinia, 231.

Service Berry, 107.

Sesban, 123.

Sheep Sorrel, 62.

Shepherd's Purse, 90.

Shooting Star, 175.

Sicyos, 228.

Sida, 147.

Sida, Elliott's, 147.

Sida, Prickly, 147.

Side-saddle Flower, 93.

Silene, 70.

Silphium, 241.

Silver-bell, Four-winged, 177.

Silver-bell, Two-winged, 177.

Simardbace $\boldsymbol{E}, 133$.

Sisyrinchium, 42.

Sitilias, 234.

Skullcap, Heart-leaved, 202.

Smartweed, Hairy, 64. 
Smartweed, Water, 63.

SMilace $\pi, 36$.

Smilax, 36.

Smilax Family, 36.

Smoke Tree, 138.

Snake-head, 210.

Snakeroot, Black, 165.

Snakeroot, Button, 164.

Snakeroot, Samson's, 120.

Snakeroot, Virginia, 61.

Snapdragon, 210.

Sneezeweed, 245.

Solanace e, 204.

Solanum, 205.

Solidago, 238.

Solomon's Seal, Hairy, 34 .

Solomon's Seal, Smooth, 34 .

Sonchus, 233.

Sophia, 91.

Sorrel Family, 131.

Sour-wood, 171.

Sow Thistle, 233.

Sow Thistle, Spiny, 233.

Spanish Dagger, 33.

Spanish Moss, 23.

Spanish Needles, 244.

Spearwort, Low, 81.

Specularia, 229.

Spice-bush, 86.

Spider Flower, 92.

Spiderwort, 25.

Spiderwort Family, 24.

Spiderwort, Hairy, 25.

Spigelia, 181.

Spikenard, 162.

Spirea, 101.

Spirea, Willow-leaved, 101.

Spring Beauty, 68, 77.

Spring Daisy, 247.

Spurge Family, 135.

Spurge, Flowering, 136.
Spurge Nettle, 136.

Spurge, Spotted, 136.

Squash, Crookneck, 227.

Squash, Summer, 227.

Staff-tree Family, 140.

St. Andrew's Cross, 150.

Star-grass, 40.

Star of Bethlehem, 32.

Starry Campion, 70.

Steironema, 174.

St. John's-wort, Dwarf, 151.

St. John's-wort Family, 150.

St. John's-wort, Spotted, 151.

Storax, Downy, 178.

Storax Family, 176.

Storax, Large-leaved, 178.

Storax, Smooth, 177.

St. Peter's-wort, 150.

Strawberry Bush, 140.

Strawberry, European, 103.

Strawberry Geranium, 103.

Strawberry-shrub Family, 84.

Strawberry, Wild, 103.

Strophostyles, 129.

Stuartia, 149.

Stuartia, Round-fruited, 149.

Stylosanthes, 123.

Styracacee, 176.

Styrax, 177.

Sumac, 137.

Sumac Family, 137.

Sumac, Fragrant, 137.

Sumac, Staghorn, 137.

Sundew Family, 94.

Sundew, Round-leaved, 94.

Sundew, Short-leaved, 95.

Sundew, Thread-leaved, 94.

Sundrops, 160.

Sunflower, 243.

Sunflower, Wild, 243.

Sunflower, Woodland, 243. 
Supple Jack, 142.

Swamp Lily, 39.

Swamp Poplar, 47.

Sweet Alyssum, 91.

Sweet Bay, 74.

Sweetbrier, 105.

Sweet-Gum, 99.

Sweet Leaf, 176.

Sweet-leaf Family, 176.

Sweet-scented Shrub, 85.

Sweet William, 71.

Sycamore, 99.

Sycamore Family, 99.

Symphoricarpus, 225.

SymplocaCe 176.

Symplocos, 176.

Syndesmon, 80.

Syringa, Garden, 97.

Syringa, Large-flowered, 97.

Tangleberry, 172.

Taraxacum, 232.

Taxodium, 14.

Tea, 149.

Tea Family, 149.

Tecoma, 216.

Teucrium, 201.

Thalictrum, 82.

Thaspium, 164.

Theace e, 149.

Thistle Family, 234.

Thistle, Tall, 246.

Thistle, Yellow, 247.

Thorn-apple, 208.

Thoroughwort, Round-leaved, 237.

Thoroughwort, White, 237.

Thymeleace 155.

Thyrsanthema, 247.

Tickseed, 244.

Tickseed, Running, 244.
Tilia, 145.

Tiliace e, 145.

Tillandsia, 23.

Titi, 139.

Toad-flax, 209.

Tomato, 207.

Toxylon, 57.

Tradescantia, 25.

Tree of Heaven, 133.

Trichostema, 202.

Trifolium, 118.

Trilisa, 238.

Trillium, 35.

Trumpet Flower, 216.

Trumpet-leaf, 94.

Trumpet-leaf, Spotted, 94.

Tulip Tree, 75.

Tupelo, 166.

Twin-berry, 221.

Typha, 16.

TYPhaCeE, 15.

Ulmace 54.

Ulmus, 55.

UMBELLIFER $\boldsymbol{E}, 162$.

Umbrella Tree, 133.

Umbrella Tree, Large-leaved, 74 .

Umbrella Tree, Long-leaved, 74 .

Unicorn Plant, 217.

Unicorn-plant Family, 216.

Unicorn Root, 27.

Urtica, 58.

URTICACE E, 58.

Utricularia, 214.

Uvularia, 28.

VaCciniace 171.

Vaccinium, 172.

VALERIANACE 226.

Valerianella, 226.

Valerian Family, 226. 
Valerian, Greek, 194.

Vanilia Plant, 238.

Velvet Leaf, 147.

Venus's Looking-glass, 230.

Verbascum, 209.

Verbena, 199.

Verbenace 19.

Verbena Family, 199.

Verbena, Wild, 200.

Vervain, European, 199.

Vervain, Narrow-leaved, 199.

Vetch, Common, 125.

Vetch, Dwarf, 126.

Vetch, Hairy, 126.

Vetch, Louisiana, 125.

Vetch, Veiny, 126.

Viburnum, 224.

Vicia, 125.

Vinca, 185.

Vincetoxicum, 188.

Vincetoxicum, Carolina, 188.

Vincetoxicum, Large-leaved, 188.

Viola, 152.

Violacee, 152.

Violet, Bird's-foot, 153.

Violet, Dame's, 91.

Violet, Early Blue, 153.

Violet, English Sweet, 153.

Violet Family, 152.

Violet, Halberd-leaved, 153.

Violet, Meadow, 153.

Violet, Primrose-leaved, 153.

Virginia Creeper, 144.

Virgin's Bower, 80.

Vitace e, 143.

Vitex, 201.

Vitis, 143.

Wahoo, 140.

Wake-robin, Large-flowered, 35.

Wake-robin, Sessile-flowered, 35.
Wake-robin, Underwood's, 35.

Walnut, Black, 45.

Walnut Family, 44.

Watercress, 89.

Watercress, Yellow, 89.

Water-leaf Family, 194.

Water-leaf, Large-leaved, 194.

Water Lily, White, 72.

Watermelon, 228.

Water Plantain, 16.

Water-plantain Family, 16.

Water Willow, 218.

Water Willow, Loose-flowered, 218.

Waxberry, 46.

Weigela, 226.

White Alder, 167.

White-alder Family, 167.

White Avens, 104.

White Milkweed, 187.

Wild Onion, 30.

Wild Onion, Striped, 30.

Willow, Black, 48.

Willow Family, 47.

Willow, Weeping, 48.

Wistaria, 121.

Witch Hazel, 99.

Witch-hazel Family, 98.

Withe-rod, 224.

Wood Sorrel Violet, 131.

Wood Sorrel, Yellow, 131.

Wormseed, 65.

Xanthoxylum, 132.

Yarrow, 245.

Yucca, 33.

Yucca, Aloe-leaved, 33.

Zornia, 123. 
ADVERTISEMENTS 



\section{BOOKS ON BOTANY}

Text-Books and Supplementary Readers.

Bergen's Elements of Botany. By Joseph Y. Bergen, Instructor in Biology in the English High School, Boston. 332 pages. Fully illustrated. For introduction, \$I.IO.

Gregory's Elements of Plant Anatomy. By Emily L. Gregory, late Professor of Botany in Barnard College. 148 pages. Illustrated. For introduction, \$1.25.

Campbell's Elements of Structural and Systematic Botany. For high schools and elementary college courses. By Douglas H. CAMPBell, Professor of Botany in the Leland Stanford Junior University. 253 pages. For introduction, \$I.I 2.

Ward's Plant Organization. By R. HALsTed WARD, formerly Professor of Botany in the Rensselaer Polytechnic Institute, Troy, N.Y. 4to. 176 pages. Illustrated. Flexible boards. For introduction, 75 cents.

Hale's Little Flower-People. By Gertrude E. Hale. Illustrated. 85 pages. For introduction, 40 cents.

Bergen's Glimpses at the Plant World. By FAnny D. Bergen. Fully illustrated. 156 pages. For introduction, 50 cents.

Newell's Outlines of Lessons in Botany. For the use of teachers or mothers studying with their children. By JANE H. NEwELL.

Part I. : From Seed to Leaf. I50 pages. Illustrated. For introduction, 50 cents.

Part II. : Flower and Fruit. 393 pages. Illustrated. For introduction, 80 cents.

Newell's Reader in Botany. Selected and adapted from well-known authors. By Jane H. Newell.

Part I. : From Seed to Leaf. I99 pages. For introduction, 60 cents.

Part II. : Flower and Fruit. 179 pages. For introduction, 60 cents.

Morley's Few Familiar Flowers. By Margaret W. Morley. Sq. I 2 mo. Cloth. 274 pages. Illustrated. For introduction, 60 cents.

Morley's Flowers and their Friends. By Margaret W. Morley. Sq. I 2mo. Boards. Illustrated. 255 pages. For introduction, 50 cents.

Morley's Seed-Babies. By Margaret W. Morley. Sq. I 2 mo. Boards. 75 pages. Illustrated. For introduction, 25 cents.

\section{GINN \& COMPANY, Publishers,}

Boston. New York. Chicago. Atlanta. Dallas.




\section{TEXT-BOOKS ON SCIENCE}

FOR HIGHER SCHOOLS AND COLLEGES.

Gage's Principles of Physics. $\$ 1 \cdot 30$

Gage's Elements of Physics. (Revised)

I.I 2

Gage's Physical Experiments .35

Gage's Physical Laboratory Manual and Note-Book .35

Gage's Introduction to Physical Science 1.00

Dolbear's First Principles of Natural Philosophy 1.00

Hastings and Beach's General Physics

2.75

Stone's Experimental Physics

1.00

Wentworth and Hill's Text-Book of Physics

I.I 5

Sabine's Students' Manual of a Laboratory Course in Physical

Measurements

1.25

Williams' Elements of Chemistry

I.IO

Williams' Introduction to Chemical Science.

.80

Williams' Chemical Experiments .50

Williams' Laboratory Manual of Inorganic Chemistry. .30

Thorp's Inorganic Chemical Preparations.

I. 50

White's Elementary Chemistry

1.00

Evans' Introductory Course in Quantitative Chemical Analysis... .50

Young's Elements of Astronomy. (Revised).

1.60

Young's Lessons in Astronomy

1.20

Young's General Astronomy. (Revised)

2.75

Frost's Scheiner's Astronomical Spectroscopy................................ 4.75

Upton's Star Atlas 2.00

Bergen's Elements of Botany

I.10

Davis' Elementary Meteorology.

2.50

Blaisdell's Practical Physiology

I.10

Lincoln's Hygienic Physiology

.80

Davis' Physical Geography

Byrd's Laboratory Manual in Astronomy

\section{GINंN \& COMPANY, Publishers,} Boston. New York. Chicago. Atlanta. Dallas. 




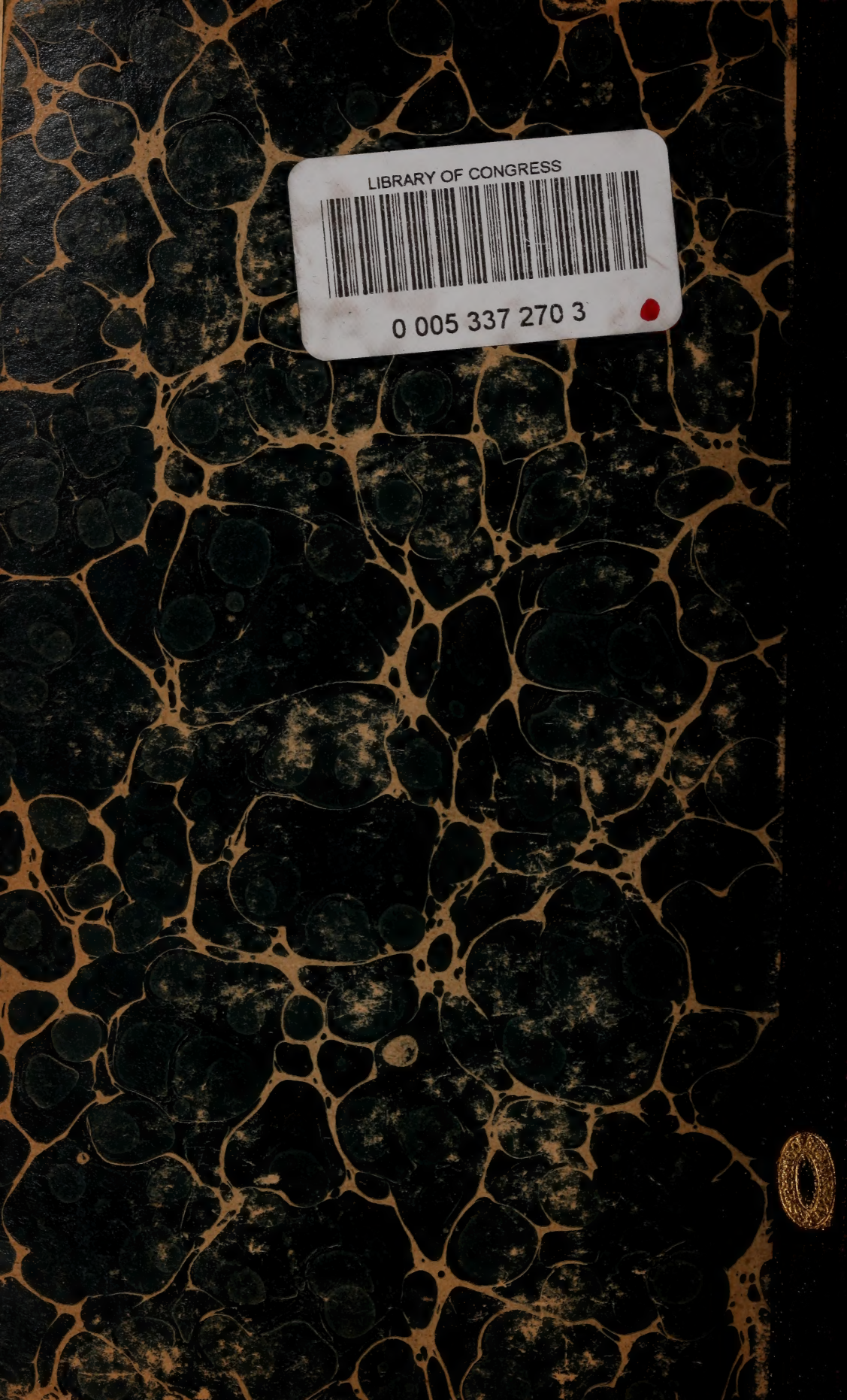

